\title{
Use and abuse of reindeer range
}

Olof Eriksson, Mikael Niva \& Alexandro Caruso 



\section{Use and abuse of reindeer range}

Olof Eriksson, Mikael Niva and Alexandro Caruso 
ISBN 978-91-7210-087-9 (paperback)

ISBN 978-91-7210-487-7 (cloth)

ISSN 0084-5914

Editor: Erik Sjögren

Cover illustration: Gullris - Solidago. Tuschteckning av Gunnar Östman Inga, 2004.

(C) O. Eriksson, M. Niva \& A. Caruso 2007

Edidit:

Svenska Växtgeografiska Sällskapet

Villavägen 14

SE-752 36 Uppsala

Lay-out: Opulus Press AB

Printed in Sweden by Fingraf, Södertälje. 


\section{Abstract}

Abstract. Eriksson, O., Niva, M. and Caruso, A. Use and abuse of reindeer range. - Acta Phytogeogr. Suec. 87. Uppsala.

In consequence of variations in geology and soils, in climate, and in its wide extent in longitude, latitude and altitude, the Scandinavian mountain chain exhibits major variations in natural conditions. Nature is constantly influenced by processes that include both natural forces and human activity.

In the early 1990s, there was an intense media debate about current damage to the montane vegetation, which many believed they could observe.

In 1992, the World Wide Foundation for Nature, WWF, invited representatives of responsible authorities, reindeer-husbandry interests, voluntary conservation bodies and interested researchers to a conference, which, somewhat erroneously, came to be called the 'Reindeer grazing conference', but which included a spectrum of factors that can affect the montane vegetation.

One result of this conference was that, in 1993, WWF initiated a research project, extending over several years, intended to provide information about temporal changes in montane vegetation.

Experimental areas distributed along the Swedish mountain chain were selected: the southermmost are on Fulufjället in Dalama, and the nothemmost are ca. $15 \mathrm{~km} \mathrm{~S}$ of Tavvavuoma in Swedish Lapland. (Some placenames are given in modem North-Saamish spelling in Appendix 2) The vegetation types studied were Grass heath, Meadow with low herbs, Dry heath, Birch forest-heath type with lichens and Birch forest-heath with mosses. These cover all major montane areas and are important grazing areas for reindeer.
At all study sites, six adjacent plots were selected, half of which were fenced to deny access to larger herbivores, and half were left open for grazing by all herbivores. The composition of plant communities in the field, bottom and tree layer in plots was estimated in 1995-96, and re-estimated three to four years later.

Generally, marginal or no effects of enclosure were seen on the vegetation communities, and there were no differences between vegetation types.

Up to the end of the 19th century, travellers in the montane region, both Saami and outsiders, ocularly assessed the plant cover. As a rule, they reported a good supply of reindeer fodder plants, especially lichen species.

From the end of the 19th century, there began to be observations of severely denuded lichen cover, especially in areas exposed to a veritable invasion of Saami and reindeer from the north-Norwegian and north-Finnish reindeer grazing areas. Incomers from those areas introduced an extensive form of reindeer husbandry, developed to suit conditions on the Finnmarksvidda and in northernmost Finland, where large reindeer herds could readily find grazing on well-demarcated headlands and islands during the snowfree season, without much supervision.

The conflicts of interest between the incomers, and indigenous Saami who wished to carry on an intensive form of reindeer husbandry, with closely supervised herds, were great. From the beginning of the 20th century, state interventions, in the form of commissions of enquiry and field surveys, were instituted. Their aim was to resolve existing conflicts, to ensure a sustainable access to grazing, and satisfactory profitability. The results cannot be said to have been satisfactory. 


\section{Contents}

Abstract

$\begin{array}{ll}\text { Preface } & 7\end{array}$

$\begin{array}{ll}\text { Acknowledgements } & 9\end{array}$

$\begin{array}{ll}\text { Introduction } & 10\end{array}$

Botanical research 13

Large-scale exploitation of mountain regions $\quad 18$

Data for decision-making in Swedish-Norwegian reindeer grazing conventions

- new knowledge of nature in mountain regions $\quad 19$

National Parks

Present-day maps of the mountains $\quad 21$

$\begin{array}{ll}\text { 1. The reindeer } & 22\end{array}$

$\begin{array}{ll}1.1 \text { Origin } & 22\end{array}$

1.2 Reindeer feeding $\quad 25$

Pastures in the mountain birch woodlands $\quad 26$

$\begin{array}{ll}1.3 \text { Fertility } & 28\end{array}$

1.4 Diseases 228

$\begin{array}{ll}1.5 \text { Mortality } & 28\end{array}$

$\begin{array}{lr}1.6 \text { Slaughter } & 29\end{array}$

$\begin{array}{ll}1.7 \text { Herd size over time } & 30\end{array}$

1.8 Reindeer domestication and handling $\quad 33$

Saami and reindeer husbandry - some definitions

Husbandry of forest reindeer $\quad 34$

Mountain reindeer husbandry $\quad 35$

Good grazing - poor grazing $\quad 35$

The Saamis and the authorities

The silver-mining era and the Saamis

The colonisation of the Saami territories

Regulations concerning the Saami territories

The boundary of the Saami territories $\quad 38$

1.9 Reindeer grazing and availability of grazing, from the time of Olaus Magnus 39

Reports from pioneers in Lapland

Linnaeus' travels in Dalarna and Lappland $\quad 40$

Zetterstedt's journey in Torne Lappmark

Zetterstedt's journey in Ume Lappmark

The Lapp bailiffs' yearbooks $\quad 42$

The Lapp bailiffs in Norrbotten $\quad 42$

Lapp bailiffs in Jämtland $\quad 42$ 
The Saami view of the grazing situation

$R$. Hult's attempt to deduce the laws governing the composition of plant formations

Observations on reindeer grazing during the 20th century, by botanists working in the mountains

\section{The WWF-project, Background}

2.1 Project objectives and study sites

2.2 Geology

2.3 Physical geography

2.4 Climate and weather

Growing season

Humidity

2.5 Vegetation types

Grass heath

Meadow with low herbs

Dry heath

Mountain birch forests

Extent of vegetation types studied

Establishment of sample plots

3. The WWF-project: How it was carried out

Shrub and tree layer

Presence of herbivores

Data processing

Ordination

Cover

Frequency

Shrub and tree layer

4. The WWF-project: Results

4.1 Birch forest heath type with mosses and dry heath 64

$\begin{array}{ll}\text { Species present } & 64\end{array}$

Shannon's diversity index $\quad 65$

Ordination $\quad 66$

$\begin{array}{ll}\text { Cover } & 66\end{array}$

4.2 Birch forest-heath type with lichens $\quad 72$

$\begin{array}{ll}\text { Species present } & 72\end{array}$

$\begin{array}{ll}\text { Shannon's diversity index } & 73\end{array}$

$\begin{array}{ll}\text { Cover } & 73\end{array}$

Frequency $\quad 74$

$\begin{array}{ll}\text { Shrub- and tree-layer } & 74\end{array}$

$\begin{array}{ll}\text { Droppings } & 75\end{array}$ 
$\begin{array}{ll}\text { 4.3 Ritsem meadow with low herbs and dry heath } & 75\end{array}$

Species present $\quad 75$

Shannon's diversity index $\quad 76$

Ordination $\quad 76$

$\begin{array}{ll}\text { Frequency } & 78\end{array}$

$\begin{array}{ll}\text { Droppings } & 78\end{array}$

4.4 Tjuolmajaure and Puollanvare $\quad 79$

$\begin{array}{ll}\text { Species present } & 79\end{array}$

$\begin{array}{ll}\text { Shannon's diversity index } & 79\end{array}$

$\begin{array}{ll}\text { Ordination } & 79\end{array}$

$\begin{array}{lr}\text { Cover } & 80\end{array}$

5. The WWF-project: Discussion $\quad 82$

$\begin{array}{ll}\text { Species diversity } & 83\end{array}$

$\begin{array}{ll}\text { Ordinations } & 83\end{array}$

Cover of the species $\quad 84$

Shrub and tree canopy cover $\quad 86$

$\begin{array}{lc}\text { 5.1. Concluding thoughts } & 87\end{array}$

$\begin{array}{lr}\text { References } & 89\end{array}$

$\begin{array}{ll}\text { Appendix I. Recorded species } & 95\end{array}$

Appendix II. Saami names for utility goods, botanical names, villages and study sites, and list of persons who provided information 


\section{Preface}

The Scandinavian mountain chain (the Scandes) or the Kjöl ('Keel') (Ljungner 1948), part of which is situated in Sweden, is a part of the Caledonian mountain chain, which intermittently stretches from Ireland to northern Greenland. It exhibits a wide range of variation with regard to natural characteristics. This is partly because of differences in bedrock and soil type, climatic gradients in both north-south and east-west directions, as well as in altitude. These differences in abiotic conditions contribute to the occurrence of a large number of vegetation types. Factors that most clearly form the vegetation are snow protection and water. Over a short distance it is possible to note a shift from surfaces exposed to the wind, with sparsely occurring lichens, mosses and low-creeping dwarf shrubs, to slightly taller shrub-dwarf shrub vegetation or even luxuriant vegetation. In the mountain birch forest and on the open mountain, there are almost 600 vascular plant species, about 300 moss species and more than 600 lichen species.

As in other parts of Sweden, nature in the mountain chain has been influenced, and still is influenced, by both natural forces and anthropogenic activities. It is simultaneously exposed to exploitation by land-based industries, of which energy generation, mining, reindeer husbandry and mass tourism are the largest, the most space-requiring and those that possibly have the greatest effect on vegetation. Nature in these areas is also utilised by the local population and visitors from elsewhere, for recreation in different forms on a smaller scale, e.g. fishing and hunting. Despite the exploitation pressure, the mountains are nonetheless one of Sweden's most undisturbed environments and, in an international perspective, possess extremely important natural values. Aronsson (1997), among others, even speaks of 'Europe's last wilderness', but then probably disregards northern Russia west of the Ural Mountains.

Anthropogenic influence on more or less extensive areas in the mountains today can be traced far back into history. Before the beginning of the 20th century, there was little discussion on whether anthropogenic activities could imply a risk of wear-and-tear on what was then considered an almost infinite wilderness. At that time it was not even valued to any extent, to judge from the name given to it by the authorities - state owned waste lands, 'kronoöverloppsmark' - referring to areas retained by the Swedish State when partitioning land in mountain regions.
Emergence of the National Park concept in the late 19th century led to some change of opinion, and a debate about the conservation of wilderness areas was started. In 1880, the discoverer of the Northwest Passage, the geologist and polar explorer A.E. Nordenskiöld, brought up the question of Swedish National Parks. At that time hydroelectric power and natural resources had begun to be exploited by society, which had led to a more extensive communication system even in the mountain areas. Improved communications then led to mountain tourism, initially on a modest scale, but which, despite its taking place only on foot, by ski or by rowing boat, was considered by some as a potential environmental threat.

In 1909, the Swedish Parliament decreed that national parks similar to those in the United States (e.g. Yellowstone 1872) should be established in different parts of the country, to protect valuable environments for all time. Examples in the mountain regions are Peljekaise, Sarek, Sånfjället and Stora Sjöfallet, all of which were established between 1909 and 1913. The last of these was severely reduced in size when hydroelectric interests succeeded in persuading Parliament that its waterfalls could be exploited to produce electricity. Abisko National Park was established in 1919 and Vadvetjåkko in 1920.

Towards the end of the 20th century, a new debate on the mountain regions emerged, this time based on observations of accelerating wear-and-tear on mountain nature, reported by devoted nature enthusiasts and by various research projects. The root of this debate may possibly be found in the Lövhögen area, an isolated area of low mountains close to the border between the provinces of Dalarna and Härjedalen to the west of Lillhärdal, one of the home ranges in Sweden of the wild reindeer (Rangifer tarandus tarandus L.). The last of these animals was reported to have been exterminated during the 1860s (Lönnberg 1909). Since that time, there have been no reindeer in the area, until the end of the 1950s, when domestic or semi-wild reindeer (these too were Rangifer tarandus tarandus L.), began to enter the area in increasingly large numbers. Their effect on the part of the plant cover that was dominated by lichens was considerable (Höglund 1970), and was later studied in greater detail by Höglund \& Eriksson (1973).

Already in the 1980s, Nils G. Lundh, Funäsdalen, was one of the foremost figures in the debate among natureconservation enthusiasts. With the help of a camera, he tried to record temporal changes in the mountain vegeta- 
tion cover, on both the Swedish and on the Norwegian (reindeer-free) side of the international border.

Lundh (1998) used older publications (Schmidt 1801, Bäcklin 1982) in an attempt to demonstrate that the vegetation changes were relatively recent and were related to the excessive grazing pressure and trampling caused by reindeer. His views were supported by Kullman (1989), Boberg (1992), Oksanen (1992) and Ihse \& Allard (1995).

Although the debate on wear-and-tear on mountain vegetation initially focussed on the excessive utilization of the soil cover by reindeer and reindeer management, other influential factors were also considered. Among other factors, Kullman $(1979,1989,1998$, etc.), who for many years had studied the relationship between climate and vegetation at the tree-limit in the mountains, asserted that an ongoing climatic deterioration was of great importance in impoverishing the vegetation. Mechanical wear caused by visitors and cross-country vehicles also came into focus, as revealed in studies by e.g. Borgegård et al. (1975), Emanuelsson (1984), Wallsten (1988) and Renman (1989).

The first study that reported acid precipitation in the mountains was published as early as 1971: Andersson et al. (1971) reported that sensitive fish species had disappeared from waters on Mt. Fulufjäll by the mid-1960s. Similar reports later came from other southerly mountain areas. Degerman et al. (1992) presented a compilation of the knowledge available at that time on acidification of mountain environments. As regards terrestrial vegetation, it was found that only a few reports had been published. However, various observations of presumed negative effects on the lichen cover were reported.

In 1995, at the request of the government, the Environmental Advisory Committee (Miljövårdsberedningen) submitted an analysis of the environmental situation, and proposals for measures to be introduced for ensuring sustainable development in Sweden's mountain regions. This work was based on existing enquiries and proposals, various published scientific reports, reports from national authorities and organizations, hearings with the local population and personal observations, etc. Particular attention was given to conditions in the southern part of the mountain chain.

From a botanical point-of-view, the following proposals, among others, are of interest:

Because it was a land-based industry, the reindeer industry was required to shoulder especial responsibility for environmental considerations.

It was proposed to regulate the right to drive on snow-free terrain in the open mountains, to minimize damage to the soil and vegetation.

The right to travel by snow-scooter should be restricted to a considerably greater extent to established tracks, in both the mountains and forest areas.

In 1992, the World-Wide Fund for Nature (WWF) arranged a conference on 'The Reindeer Grazing Problem' at which representatives of the reindeer industry and the relevant authorities conducted a broad-ranging discussion with nature conservationists and scientists. It became clear that reindeer husbandry alone could not be accused of being responsible for the ongoing processes. A visible result of the conference was that the WWF's project committee decided to initiate a comprehensive research project, with Lennart Nyman as leader, which from the start became known, rather unfortunately, as the 'reindeer grazing project'. Certain influential factors other than reindeer grazing land were also to be studied.

The project was intended to demonstrate any changes in the vegetation within the study area along the mountain chain - both retrospectively and in the future. It was hoped that the facts obtained could be used, together with others, in planning land utilization by land-based industries. The methods employed should also be useful for the purposes of environmental monitoring. Thus, the work should contribute to the long-term conservation of today's mountain environment, and should also serve as a platform for measures designed to return the mountain vegetation to its former richer state, principally with regard to biomass.

The project dealing with vegetation consists of two sub-projects. A study of changes in plant communities, vegetation cover and erosion using remote analysis is being made through comparative interpretation of existing infrared (IRF) aerial photographs from the early 1980s, and those more recently taken. The potential of satellite technology is also utilised, whereby mainly Landsat TM pictures are compared with aerial photographs as part of an effort to develop the method (cf. Ihse \& Allard 1995, Allard, et al. 1998, Allard 2001). This sub-project has been carried on at the Department of Physical Geography, Stockholm University, and is reported separately (Allard 2003).

The ground-based sub-project that will be presented in what follows is based on repeated plant counts on fenced and open sample areas situated in vegetation types commonly found in areas ranging from Fulufjället, Dalarna, in the south, to the region of Tavvavuoma (Davvavuopmi), Lapland, in the north. This report covers the initial phase and the first revision after 3-5 years. The cover and frequency of the plant species/groups present have been recorded. Among factors that may influence 
species diversity and plant biomass, it has been possible to record, to some extent, the effect of weather conditions during the growing season and traces of the presence of large herbivores. A similar project in the Tavvavuoma area, started in 1967-1968, has been incorporated in this sub-project. The Department of Plant Ecology, Uppsala University, has been the base for this work.

\section{Acknowledgements}

The main provider of funding is the World Wide Foundation for Nature - WWF. As a coordinator, Ola Jennersten at WWF in Stockholm has had great patience with us. Contributions, both economic and logistic, have been received from the County Administrations in Dalarna, Jämtland and Norrbotten, and from the Swedish Environmental Protection Agency. The Phytogeographical Society made it possible for us to publish in its Acta Phytogeographica Suecica series. Professor emeritus Eddy van der Maarel and Professor Jon Ågren at the Dept. of Plant Ecology, Uppsala University placed rooms at our disposal within the department; Jon assisted with statistical analysis during the project. Senior-officer Tuomo Raunistola (late), Section for Reindeer husbandry at the County Administration in
Norrbotten, has been of great help, e.g. as coordinator and coach when teams were to start field work in different places at the same time. Dr. Ingvar Backeus and Willy Jungskär, Dept. of Plant Ecology, Uppsala University, helped us to organise the initial phases of the computer processing. Professor Kurth Perttu, Dept. of Short Rotation Forestry, Swedish University of Agricultural Sciences (SLU), gave generous help in the handling of meteorological data. Professor Bernt Jones, SLU, helped us describe reindeer deseases. Great help was given by Susanne Idivuoma and Ulla Svedell in checking the Saamish terminology. The translation from Swedish to English and correction of our English was done by the late Nigel Rollison, subsequently continued by Dr. Jeremy Flower-Ellis. The Police Authorities in Gällivare and Kiruna generously allowed us to use their excellent accommodations during fieldwork at Ritsem and Järämä (Jarin). The editor of the Phytogeographic Society, docent Erik Sjögren, showed angelic patience and also offered continual encouragement during the writing process.

And last but not least, especial thanks go to our families, for their love, understanding and indispensable practical and emotional support during the all-too-lengthy writing period.

We are most grateful to all of you.

Uppsala 2007,

Olof Eriksson, Mikael Niva and Alexandro Caruso. 


\section{Introduction}

From runic engravings to a vegetation map based on remote analysis - the emergence of the Swedish mountain region from the shadows of history

The earliest evidence we have of long-term human utilization of biological production in mountain regions is found by archaeologists in remnants of habitations and on stones, often with game motifs. The artists were the hunters who followed the herds of wild beasts and harvested them when the opportunity occurred. After southern Scandinavia had become ice-free (ca. 13,500 B.C.), hunter-gatherer groups migrated into the area as early as 12,000 years B.P., following the herds of wild reindeer.

More than 8,000 years ago, the oldest surviving work of art in Scania, a reindeer hunter's tent and two reindeer, was incised on a deer antler (Liljenberg 1991).

The oldest site excavated to date in northern Sweden is situated north of lake Dumpokjauratj, east of Arjeplog, Lapland. Samples of charcoal were dated by Accelator Mass Spectrometry (AMS) radiocarbon dating, and found to be ca. 8,500 years old. A large number of Lithic Artifacts were found. Reindeer, elk and beaver were important sources of food during different periods. Colonisation is likely to have come from the north, the settlers being late descendants of the Komsa complex, who had a long northern subarctic history (Bergman, Olofsson, Hörnberg, Zachrisson \& Hellberg 2004).

The earliest finds in the mountains of south Norway are about 9,000 years old (Skogland 1994). In the Swedish provinces of Härjedalen and Jämtland, similar finds have been made, but are younger.
Agrarian colonisation, principally in the form of animal husbandry combined with the hunting of wild reindeer, occurred in some Swedish mountain valleys during the Late Iron Age (Hansson 1997). Königsson (1986) reports pollen evidence that grazing land was established during the Middle Ages near Fjällnäs in Swedish Lapland. The Mittåkläppen area in Härjedalen has become an alarming example of the current over-utilization of reindeer grazing land that already was in use for grazing during the Viking era (Wallin \& Aronsson 1998). However, we must bear in mind that the elk (Alces alces) by far was the most important large quarry during antiquity. This is testified by rich osteological material, e.g. at Vuollerim, Norrbotten county, and numerous rock carvings, e.g. at Nämforsen, Ångermanland county (Zackrisson 1992).

Before Olof Rudbeck the Younger and Linnaeus, written descriptions dealing with the northern wildernesses, including the mountains, their inhabitants as well as their animals and plants, were acquired through more or less imaginative descriptions, frequently based on unreliable sources. The descriptions by Vergil and Tacitus, who wrote during the early stages of our chronology about Ultima Thule, the unknown land situated in the farthest north, and inhabited by remarkable creatures with peculiar ways of living, are examples. Tacitus introduced the name 'fenni', still used in North Norway, whereas the Finns there have retained their former name, 'kväner'. The Fenni became renowned for their remarkable ability to use a pair of 'troll-wood' skis to pursue wild animals running over snowfields. Thus, in the 6th century A.D., the Gothic author Procopius added the prefix 'skriti' to 'fenni'. The

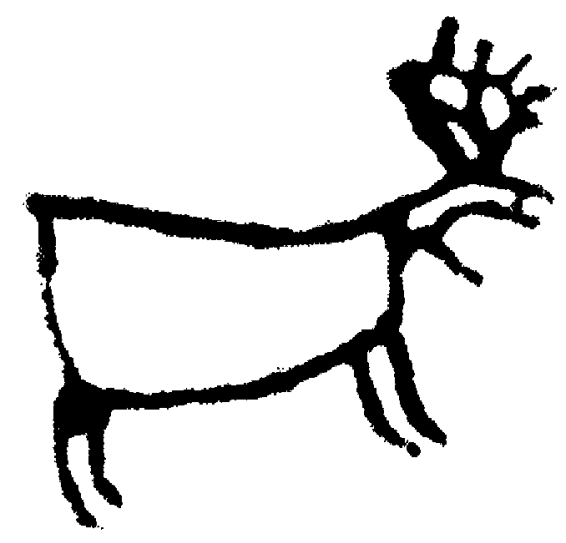

Fig. I. The oldest known rock-carving representing a reindeer, from the Neolithic era, was found in 1658 at Glöse in Alsen, Jämtland county (Hallström 1960). 


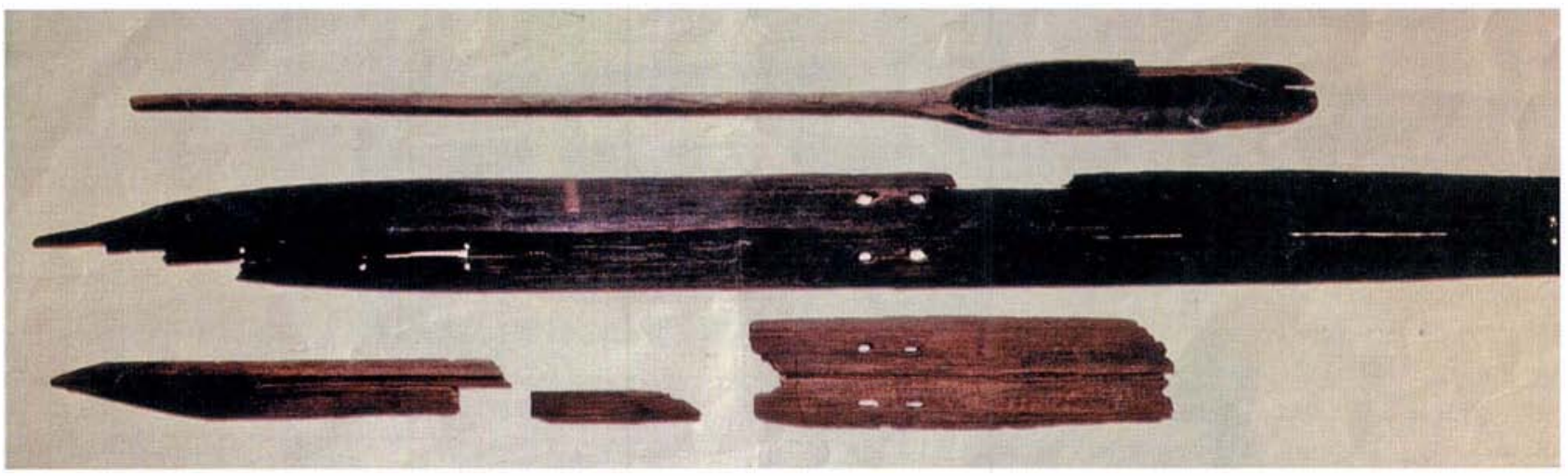

Fig. II. The Kalvträsk skis were found in a peatland at Kalvträsk, Västerbotten county. Their 14C-dated age is ca. 5200 years. This find is the oldest known, and may be ca. 500 years older than the oldest Egyptian pyramid. The bindings consisted of straps bound around the foot and threaded through four vertical holes in the footrest. This type of ski is not otherwise known from Scandinavia, but was common in parts of Siberia up to the present time, and may perhaps be regarded as one of many indications of early cultural contact with Eurasia (Åström 1993). The 'shovel staff' (Saamish gaivo-soabbi) - an aid to progress as well as a means of testing the suitability of the snow-cover for grazing - is still occasionally used.

Saami were known as ski-finns - or skiers - far back in history. Skis were, however, used long before the days of Procopius. As a proof of this, the 'Kalvträskskis' (fig. II, Åström, K. 1993) can be seen, which together with a 'skovelstav' - an early form of ski-stick - were found in 1924 during drainage work ca. $80 \mathrm{~km}$ east of Lycksele, Västerbotten county.

In the early 5 th century A.D., the Roman priest P. Orosius wrote a history book ('Historiae adversum Paganos') which over the years became a classic in Europe. In the late 9th century, Alfred the Great, King of Wessex (871899), ordered the translation of Orosius into Old English

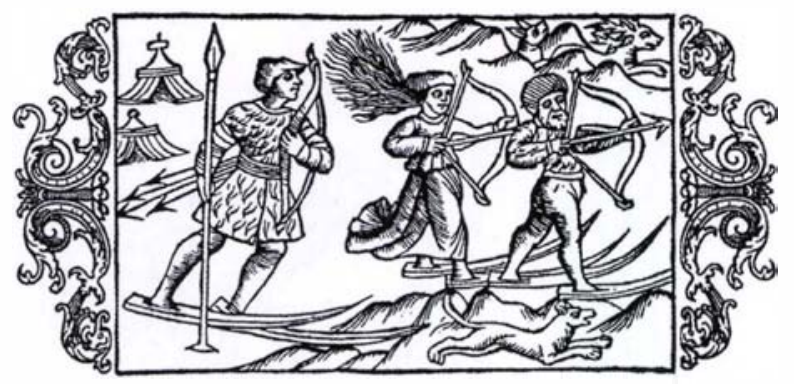

Fig. III. The 'Skridfinns' use curved, broad and smooth wooden planks bound to their feet when hunting the wild animals of the snowy mountains. The assistance of armed women is necessary for success. - However, the men always decide how the catch is allotted, and how it shall be used (O. Magnus, 1555).
(Alfred's Orosius, ca. 890). The first part contained a geographical survey of Europe south of the Alps, a region known to Orosius. Alfred supplemented the English version with a description of Europe north of the Alps. Here it is interesting to find the description of North Scandinavian conditions given by the Viking Chieftain Ottar, who lived 'northernmost of all' in Hålogaland, the northern part of Norway. Ottar visited Alfred's court around 890 A.D. He related that he had domestic animals, decoy reindeer, to assist in the capture of wild reindeer, and 600 domesticated reindeer. He had travelled extensively and had a good knowledge of how the mountain Saamislived, of taxes that had to be paid, and of those with whom barter was carried on. He had reached as far as the White Sea by ship, where the Bjarmar people had created a hunting-farming culture in the estuary of the River Dvina. Thus it is clear that the Vikings were acquainted with the northernmost regions of the Scandes and neighbouring areas of land.

In the early 13th century, the Danish historian Saxo Grammaticus wrote on 'Lappia' and its inhabitants, the 'Lapps' in 'Gesta danorum' - The History of the Danes. Until the mid-16th century very little was published that extended our knowledge of nature within the region we now know as Kölen or the Scandes - the Scandinavian mountain chain (cf. Ljungner 1948). In 1539, an excellent map of the North - Carta Marina - was published in Venice. In 1555 , this was followed by a large ethnographical work on the North - 'Historia de gentibus septentrionalibus' (The History of the Northern Peoples). The publications became of great importance as sources of knowledge for many years. The author of both was Olaus Magnus, a Swedish Catholic priest who lived in exile in Rome after the Reformation. His brother Johannes, who assisted with the work of publication, shared his fate. 
The description covers a wide spectrum, e.g. ethnography, economics, geography and natural history. The author was clearly very well read and even had personal knowledge of parts of the country, such as that acquired during a period as a bogus itinerant pedlar who travelled as far north as Norrbotten. In 1519 he reached Pello in Tornedalen. He had a considerable amount of information about the Saamis, about their neighbours at that time, about ecology of reindeer and about their value to their owners and hunters. He knew that lichens were an important component of the reindeer's winter diet, as well as that their hooves were particularly suitable for a life under snowcovered conditions. The mountain chain that separated Sweden and Norway was known to him. Its name should be Mt. Doffra fjäll - a name we today associate with a region in the centre of the Norwegian part of the Scandes (Dovre). The 'History' consists of a remarkable mixture of exact observation and loans from contemporary learned publications. Pliny the Elder (24-79 A.D.) was probably the person from whom most loans were taken.

Up to the publication of Schefferus' 'Lapponia' in 1673, knowledge of the mountain region was not increased to any particular extent. The botanical research and teaching that emerged were connected with the seats of learning. Here, mention should be made of Sigfridus Aronus Forsius (ca. 1550-1624) who, at the turn of the 16th-17th century, was active as a professor at Uppsala. His main interest was astronomy, but also botany (Forsius 1611). In fact, he was the first to publish botanical works in Swedish. In 1601-1602, he journeyed to Lapland, mainly with the intention of studying border conditions between Sweden and Norway, and to map the country up to Varangerfjord. This expedition probably made him more knowledgeable about Lapland's nature than any of his contemporaries (Eriksson, G. 1969).

In 1648, Johannes Schefferus (1621-1679), who was born in Strassburg, was appointed Skyttean Professor in oratory and politics at the academy in Uppsala. He cultivated close relationships with national leaders, and in 1671 was given the task of describing Lapland and the Laps by Magnus Gabriel de la Gardie, at that time Chancellor of the Realm. Priority was to be given to ethnological aspects, such as the value of the region to the national economy. The result, 'Lapponia', was written in Latin and first published in Frankfurt am Main in 1673. It was then rapidly published in several modern languages. However, it would take almost three hundred years before it was published in Swedish, in the Acta Lapponica series issued by the Nordic Museum.

Schefferus' knowledge of Lapland is not based on what he himself saw. Apart from older sources such as Pliny, Solinus Tacitus, Procopius, Saxo and the brothers Johannes and Olaus Magnus, he used detailed reports on Lapland and its living conditions prepared for him on the order of the Chancellor of the Realm, by clergymen working in the northern parts of the country. Samuel Rheen, rector of Råneå, Johan Torneaus, a schoolmaster in Torneå, and Olaus Petri Niurenius, rector of Umeå, submitted reports that were most utilised. Their reports are characterised by distinct objectivity. Adetailed field notebook belonging to the widely travelled Johannes Bureus (1568-1652), who studied antiquities and languages (Bureus 1886), together with oral records given by Saami youngsters studying in Uppsala, supplemented the field material (G. Eriksson 1969).

The term 'fjäll' (mountains) was examined, together with their extent and function as a protective border to Norway, along a line from Jämtland to the 'Ice Sea' (Arctic Ocean). Both open mountains and mountain regions covered with birch were described, as well as the coniferous forests adjacent to the mountains. The shrub layer, where currant bushes were allowed to play a remarkably large role, was superficially described. Berries found, as well as some of the plants used by the Saami, e.g. Angelica archangelica $\mathbf{L}$. and Rumex acetosa ssp. lapponicus Hiit., were mentioned. The most important goals for reindeer
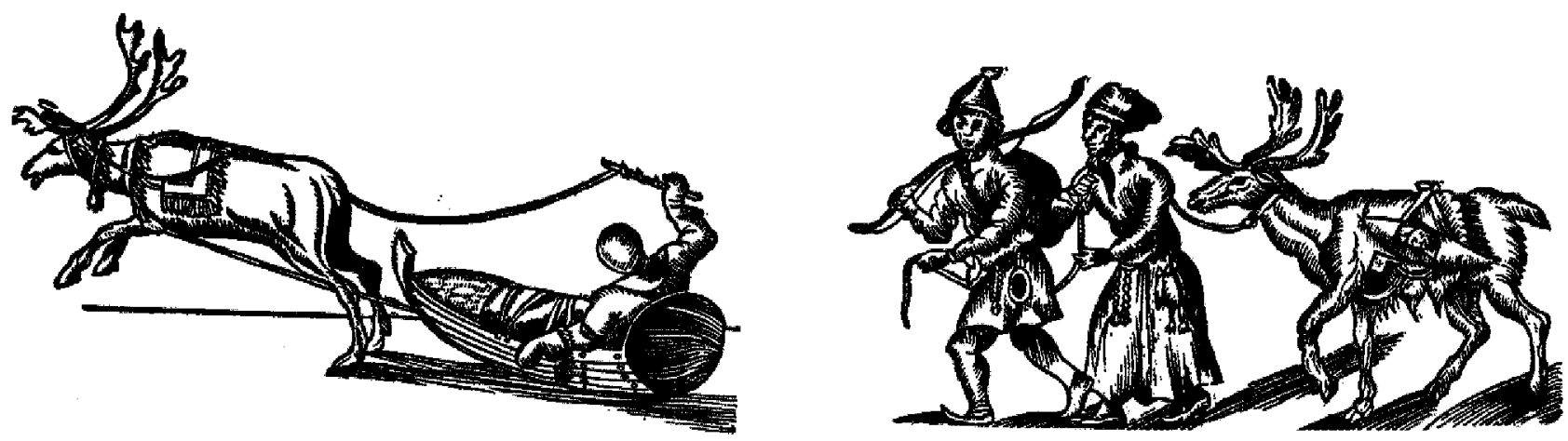

Fig. IV. Lappish women transport their children to the priest differently in winter than in summer. In winter, the child is laid in a Lapland sleigh (Saamish gieres) drawn by a reindeer. In summer, she transports the child in a cradle (Saamish gietka) on the reindeer's back. (Schefferus 1956). 
husbandry were also identified. Access to good natural grazing in mountain valleys was emphasised, together with the presence of mires that could also be used for grazing. The question of their value as potential farmland was, however, left unanswered (Schefferus 1673).

Andreas Bureus (1571-1646), a cousin of J. Bureus, has been called the father of Swedish cartography. In 1611 he published his first map (at a small scale) of the Kola Peninsula and northern Scandinavia down to latitude ca. $63^{\circ} \mathrm{N}$. Enthusiastically supported by King Gustav IIAdolf, he published a map covering all of Scandinavia and the neighbouring countries in 1626, 'Orbis arctoi nova et accurate delineatio' ('A new and accurate description of the arctic region'). Both maps are in conical projection, and may be regarded as the first real maps showing the mountain regions. It was not until 1796 that they were superseded, when the map made by Anton Swabo and Clas Wallman of Västerbotten (i.e. up to the watershed between the rivers Torneälv and Kemiälv) was published. This beautiful map was at the scale 1:440,000, and was included in S.G. Hermelin's countrywide atlas.

\section{Botanical research}

Botanical research in Sweden during the 17th century led to systematic floristics and descriptive botany. Olof Rudbeck the Elder (1630-1702) made a major contribution to this development. He began his research career in medicine at Uppsala, and discovered the lymphatic system in the mid-17th century. He published his results in 1653, shortly after the Dane, Thomas Bartholin, had independently published very similar observations. Having studied in the Netherlands during 1653-1654, where he studied not only medicine but also botany, Rudbeck returned to Uppsala, and soon became professor of medicine. He founded Sweden's first botanic garden, based partly on Dutch plant material. His professorship was altered to cover both botany and medicine. As a scientist, he represented the modern view of nature that emerged during the 17th century and, as regards botany, was formulated by, among others, Harvey and Malphigi. Rudbeck's major contribution to botany was his Campus Elysii (1702), illustrations of all the world's plants, organised so that prevailing errors in nomenclature and systematics could be corrected. Two volumes containing several hundred illustrations had been printed, before the extensive Uppsala fire of 1702 destroyed almost the entire collection of nearly seven thousand woodcuts, among which were those to be used for illustrations of plants found in the mountain regions of Sweden.

Rudbeck is probably mainly known today for his 'Atland', or 'Atlantica' (1672-1702), an historical work in which he tried to demonstrate that Plato's poetic epic 'Atlantis' was in fact a description of Sweden, the origin of all culture from whence it spread to the rest of the world. Through 'Atlantica', Rudbeck's belief about the link between Atlantis and the North became widespread. A few examples are given below:

Glysisvall - the original form for Elysium, or the Elysian Fields, the homes of the blissful, said to be found in the North during the summer.

Ida fjäll - according to Rudbeck, more or less the entire mountain chain, originating from the placename Idre. Homer's mountain Ida was said to be actually situated in the North.

Helicons berg - Härjedalen

Ararat - Åreskutan

Amazons - Hamai warriors and hunters of female gender, living in a pronounced matriarchal society. They were said to have lived to the west of the Ripheic Mountains in northern Finland. They were exterminated by Hercules, burnt and placed in three heaps at Amaisojärvi, west of the Ripheic Mountains (the name originating from the Swedish word ripa, meaning ptarmigan). That they should have been placed in three piles parallels the three burial mounds at Gamla Uppsala.

Hercules - according to Rudbeck, the first syllable refers to the Swedish word här- (host; military power), and -kules refers to the masculine form of kulla, the word used in Dalama when referring to a woman.

Olof Rudbeck's son, Olof the Younger (1660-1740) inherited his father's interest in botany and was his equal as an author. He began his academic studies in his home town of Uppsala at the age of thirteen. Botany and medicine were his main subjects, and his father, who was of course professor at the university and even Rector for a time, supervised his studies, which were supplemented with a study visit, mainly concerning botany, to England, Holland and Germany in 1687-1691. On his return he was appointed professor of medicine in succession to his father.

Economic interests, foremost those of the State, had taken early travellers to the northern wilderness. Profitable mining was the principal attraction. With Olof Rudbeck the Younger, purely scientific journeys of discovery were introduced in the north. During the summer of 1695, he made a long journey of discovery in Lapland, including visits to the true mountain region in the Luleå and Torne parts of Lapland.

Rudbeck's research journey, which was so unusual at that time, was intended to be described in a comprehensive publication: 'Nora samolad sive Lapponia illustrata' - 'Lapland illustrated'. Only one part, however, was published (in 1701), the part describing the journey from Uppsala to the border with the province of Gästrikland. The fire in Uppsala in 1702 destroyed a large part of the learned production, such as notes, manuscripts, books and most of the woodcuts. The library at Lövsta in North Uppland contains, however, botanical material illustrated in several volumes. One of them covers some of Rudbeck's mountain plants and other objects found in nature. Fragments of Rudbeck's travel notes (Rudbeck 1695) can today be found in the Linnaean Society's library in London. These allow us to glimpse some of his botanical observations. 


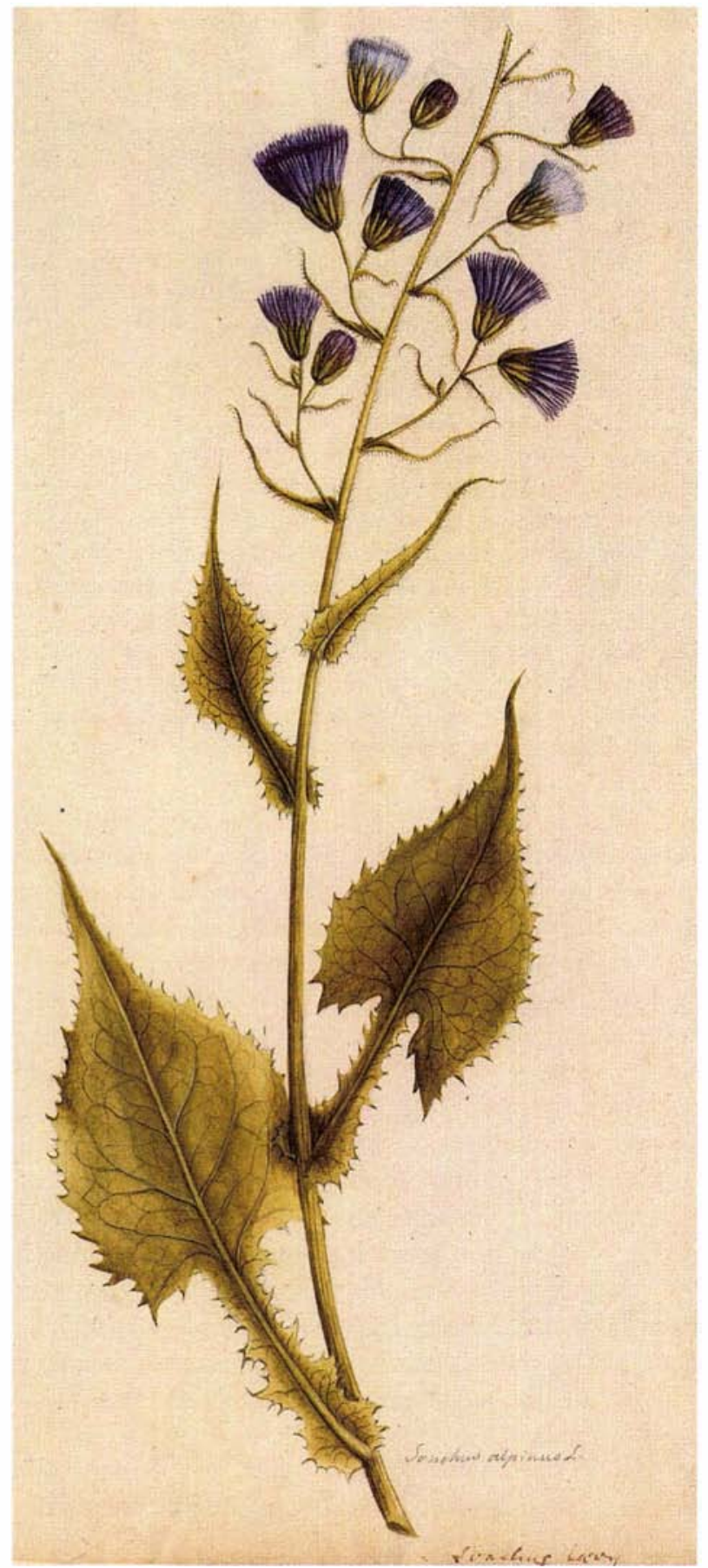

Fig. V. Cicerbita alpina (Swedish torta, Saamish jearjá). Occurs in northern Sweden in meadow forests and tall-herb meadows, from the lowland forest areas to the mountains. It is readily eaten by reindeer, elk and bears, and was an important vegetable for the Lapps. The young, peeled stalks were eaten both raw, and after being boiled together with reindeer milk (South saamish gompa). The dried roots were used as a medicine rich in vitamin C, to treat scurvy (Rudbeck, O. the Younger 1720).
During his travels in the Torneträsk area, Rudbeck found a large number of plants new to him. When considering that, on the advice of his guide, he never took more than twenty to thirty steps away from the path, his results are considerable. He also found reason to criticise Schefferus, who had considered that Lapland was particularly deficient in species as regards botany.

Whereas Schefferus, with the help of all his informants, had not managed to list more than 80 types of 'grass', Rudbeck had found more than three hundred during his first journey. In 1720 he published a list including the 95 most remarkable finds.

Phenological observations were made concerning the flowering of certain herbs at Torneträsk, in Luleå and in Uppsala, as well as various observations of a more or less plant-geographical nature. In 'Acta literaria et scientiarium Sveciae' (1734), he described in words and illustrations the 'Cascavari' waterfall at Kvikk jokk. This is the first published illustration of nature in the Lule region of Lapland.

However, interest in botany appears to have diminished gradually; perhaps the reason can be found in the losses caused by the Uppsalafire. Following the example of his father, Olof Rudbeck the Younger was also strongly attracted by the great Gothic vision. His father, for example, was influenced to such an extent that, in 'Atlantis', he placed Paradise itself in Kvikk jokk. Lapland was, of course, the former Elysian Fields where, according to ancient belief, Salix grew, and the relationship between Salix and the Swedish word 'salig' (blessed) was considered obvious.

Rudbeck the Younger saw it as his duty to demonstrate that Gothic was the origin of all languages. He found, for example, clear relationships between Gothic, the Saamish language and Hebrew. His interest in birds resulted in a richly illustrated bird book, which was not published until 1988.

Linnaeus's life, particularly during his younger years, is well known to Swedes. However, a brief recapitulation may be useful in refreshing the memory. He was born in 1707 , in a clergyman's home in rural Småland. He received a relatively good education and spent a childhood close to nature under the inspiration of his father, who was interested both in horticulture and in the wild flora. Rothman, a teacher of him at the secondary school in Växjö stimulated his growing interest in botany, by telling about the interesting botanical garden at Uppsala (which, however, at that time was in rather poor shape). The next teacher of importance was Kilian Stobaeus, who was Linnaeus's teacher in medicine and natural history during his short time at the university of Lund (1727-1728).

Linnaeus's move to Uppsala University in the autumn of 1728 gave him rather better opportunities to study medicine and a better environment and personal circle of friends, that proved to be a good base for his early scientific work in botany, its systematics, terminology and nomenclature. 

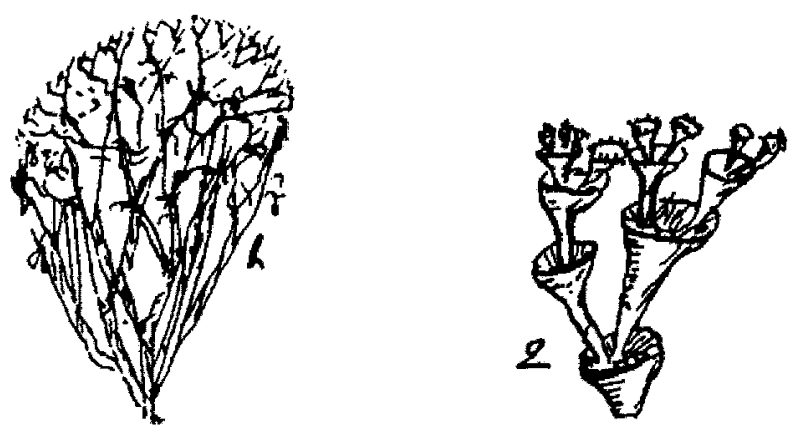

Fig. VI. In the course of his journey along the Ume River to Lycksele, Linnaeus illustrated Cladonia rangiferina var. alpestris (L.) Schaer, i.e. Cladina rangiferina (L.) Nyl., Cladina stellaris (Opiz.) Brodo or both, and Cladonia coccifera (L.) Willd. (Linnaeus 1732). The importance of lichens as reindeer fodder was already well-known, e.g. from O. Magnus (1555).

Olof Celsius, Dean of the Cathedral, gave him economic support and introduced him to Olof Rudbeck the Younger, in whose home Linnaeus was given lodgings and access to his library. In 1732 the Royal Academy of Sciences placed its entire economic resources at his disposal for a scientific jourmey to Lapland, which he made during the same summer. The intention was 'to illustrate Lapland's natural history with regard to stones, soils, water, herbs, trees, grass, mosses, quadrupeds, birds, fish and insects, together with human diseases, health, nutrition, customs and mode of living'.

An attempt to reach the mountain region of Västerbotten during the early summer ended, quite understandably, in the waterlogged Lycksmyren swamp north-west of Lycksele, after which the journey continued to Luleå and further up the river Lilla Luleälv. Themountains northwest of Kvikkjokk gave him a rich reward for his efforts. Within the space of a few weeks above the coniferous tree limit, he had collected material that formed the main part of his Flora Lapponica, printed in Holland in 1737. Contemporary scholars considered this to be his masterpiece from the first great period of publication. Nonetheless, there can be no doubt that Rudbeck's pioneering work was of great benefit to Linnaeus. Apart from a rich material of a purely botanical nature, Flora Lapponica contained a number of notes connected with the purpose of the journey. Linnaeus's diary from the journey, Iter Lapponicum, was printed in London in 1811 and became a literary classic.

As an observer of all phenomena in nature, as well as of human living conditions and behaviour in a wide sense, Linnaeus was remarkable. His division of topographic regions into biological zones of different extent, for example, was precise and even today endures in parts. He made an excellent differentiation between the mountain region's alpine belts - the forested region, forests of mountain birch, low mountains, mountain slopes and high mountains

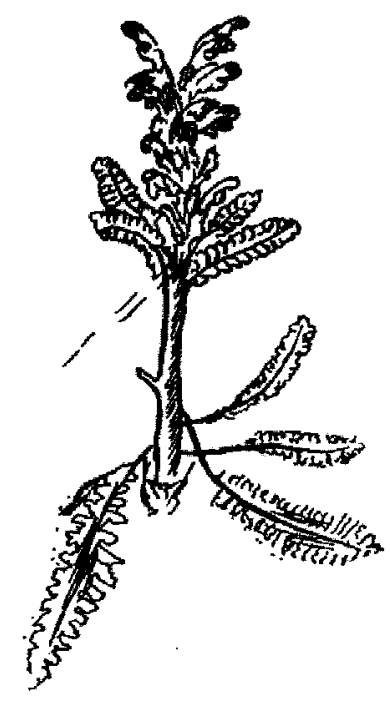

Fig. VII. Pedicularis flammea L. was illustrated by Linnaeus on his journey between Virihaure and Kvickjokk (Linnaeus 1732).

(Du Rietz 1942). Similarly, his talent as an author was of the highest class, whereas his skills as an illustrator were less developed. Nonetheless, the sketches in his diary have a naïve charm, and show evidence of a pronounced feeling for important aspects of the objects illustrated.

During the winter of 1733, Linnaeus visited Dalarna for the first time, to study mineralogy. During the following summer, at the request of the Provincial Governor in Falun, Nils Reuterholm, he traversed the countryside together with friends and assistants in a search for 'rare products of nature and economically unutilised resources within the three realms of nature'. As regards botany, the journey was a disappointment. In Iter dalecarlicum (1953), he comments laconically that Sweden's southernmost mountain region was much more deficient in species than he had imagined.

Several botanically interested physicians were among Linnaeus's disciples. One of the more prominent was Lars Montin (1723-1785), a sharp-eyed field botanist who botanised in the Kvikkjokk mountains in 1749. He was the first to find Juncus biglumis. His journey provided material for two dissertations, one on the bryophyte Splachnum luteum and the other, his graduate dissertation, on Saami diseases and medicines. Another of these botanically interested doctors was Johan Otto Hagström (1716-1792). He received much praise from Linnaeus for his dissertation on wild flowers that bees prefer to visit (Pan apium, 1768). Considerably earlier (1749), a visit to his home district of Jämtland had resulted in a dissertation on the region's economic natural history.

Linnaeus inspired his disciples to undertake adventurous expeditions to distant countries, where they were thought to function as their master's extended arms and 


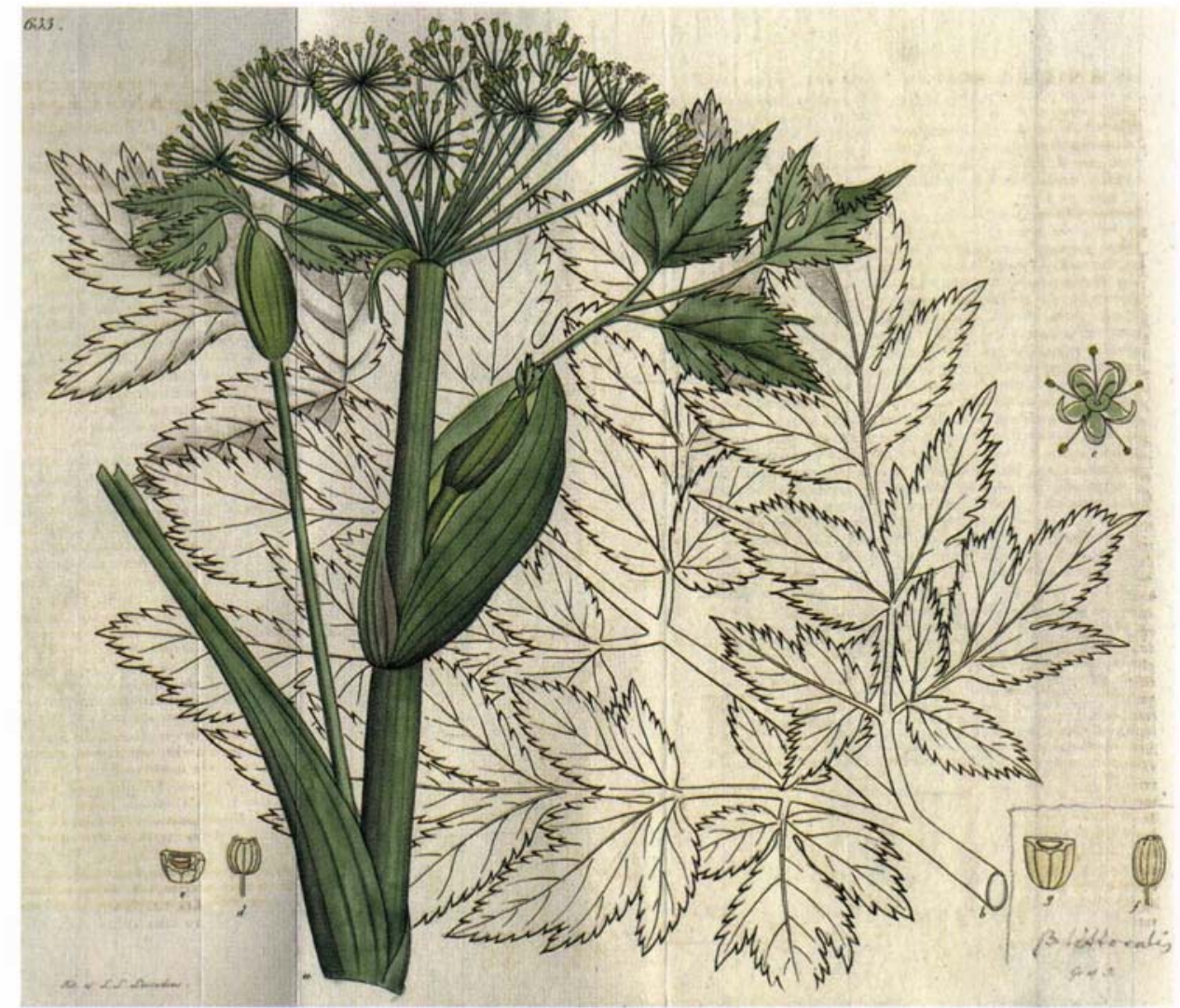

Fig. VIII. Angelica archangelica. Common on moist sites in small valleys, and beside streams and springs. An important constituent of the spring and early-summer reindeer fodder. Formerly one of the Saamis' most important vegetables (Saamish boska). Before flowering, the peeled stalks were eaten raw. Like Rumex acetosa ssp. lapponicus (Saamish juopmu), it was used as a preservative in reindeer milk, which was stored for lengthy periods in springs. It also found an extensive pharmaceutical use as a herb for loosening phlegm and for treating cramp (Wahlenberg 1830). Drawing by L. L. Laestadius (1830).

senses, diligently collecting and describing not only true scientific aspects, but also those of benefit to society. Their interest in the mountain regions of Sweden appears to have been limited. One exception was, however, Daniel Solander, born in Piteå in 1733, who arrived in Uppsala as a student in 1750 . He was one of Linnaeus's most cherished students, and went on research trips to Piteå Lappmark and Norway in 1753 , and later also visited the mountains. A study trip to England led to his abandonment of Sweden and Linnaeus, but with English support he achieved considerable success in exploring the plant kingdom in the southern hemisphere. Aboard the 'Endeavour', he took part in Captain Cook's firstcircumnavigation, when Tahiti, Tierra del Fuego, New Zealand and Eastern Australia were visited, yielding a rich collection of material.

During the mid-1750s and onwards, the Royal Academy of Sciences enthusiastically supported research expeditions to exotic countries, undertaken mainly by Linnaeus's disciples. Curiously enough, interest in discovering more about their own country was weak. However, an exception was the work carried out by two young students, Johan Daniel Lundmark, a student of medicine, and Olof Swartz, during an expedition to collect items of botanical and zoological interest in Lapland in 1780. Unfortunately, it yielded little of scientific interest. Olof Swartz later became one of Sweden's most prominent and widely travelled botanists.

Göran Wahlenberg (1780-1851) was appointed professor of medicine and botany in 1829. He extended our knowledge of the Scandinavian world of plants. His Flora lapponica (1812) and Flora Svecica (1824-1826) proved to be highly stimulating for research in floristics and systematic botany. However, his foremost achievements were in plant geography, where he, together with Alexander von Humboldt, came to be regarded as a pioneer. Wahlenberg was a withdrawn and austere person, who largely kept to himself. He had no disciples who would continue along the paths he had staked out. However, Swedish plant geography as he created it came to dominate the relatively modest research in this field during subsequent decades.

In the early 19th century, Wahlenberg made four botanical and geological expeditions to Lapland and northern 
Norway. The Sulitelma Massif, at that time considered to be Sweden's highest mountain, especially attracted his interest. In 1813, on the small mountain Unna Tuki southeast of Virihaure, he made the first find of Arenaria humifusa Wahlenb. in the Nordic countries, a species that more than a century later came to be of great importance in discussions on the early immigration of mountain flora. In the introduction to Flora lapponica (1812) he gave an account of the main characteristics in the plant-geographical structure of northern Sweden. He differentiated between the mountain vegetation zones, and correlated them with climatic conditions. During the period 1812-1814, he worked in the Swiss Alps and the Carpathian Mountains, in order to be able to compare conditions in the Swedish mountains and those prevailing in corresponding regions elsewhere in Europe.

One of Wahlenberg's successors was Lars Levi Laestadius (1800-1861). He was born in Jäckvik, parish of Arjeplog, his parents being of Saami descent. Laestadius grew up in Kvikk jokk, read theology in Uppsala and was appointed vice-pastor in Arjeplog. In 1826 he moved to Karesuando as rector, then to Pajala in 1849. Laestadius won great esteem as a botanist, particularly in floristics and plant geography. He conducted extensive journeys of botanical research, particularly in northernmost Norrland. In the early 19th century, he found Papaver laestadianum Nordh. in the Pältsa district, which came to be an important item of evidence in connection with the Nunatak theory, i.e. the discussion whether or not species were able to survive the most recent ice age on the top of mountain peaks that rose above the ice. In 1838, Laestadius participated in P. Gaimard's French expedition in Lapland, as a natural history polyglot guide. He published a number of dissertations dealing with Lapland's plants, as well as contributing drawings in Wahlenberg (1830), and providing important contributions to floras prepared by Wahlenberg, E. Fries and Hartman. Together with his family, he produced a large amount of high-quality herbarium material that was given to major botanical collections in Europe. For example, Gaimard's expedition was given nearly 10,000 sheets. In recognition of this, Laestadius received the French Legion of Honour (Larsson 1999).

Theodor (Thore) Magnus Fries (1832-1913), professor of botany and practical economy at Uppsala University, visited Öst-Finnmarken in Norway in 1857 and 1864 and, as one of the first, came to know the Arctic lichen flora thoroughly. Rutger Sernander and the lichenologists A.H. Magnusson and G.E. Du Rietz were three of his pupils.

Axel Hamberg (1863-1933) is probably the person who has meant most for exploration of the Sarek area, partly through more than thirty years' work and partly through having inspired and supported a large number of researchers within many disciplines of science. He himself was a polyhistor, with roots in biology, geology, physical geography, climatology and, in particular, glaciology. He studied, among others, the climate and glaciers in the Sarek area, and carried out advanced mapping, largely based on photogrammetry. In 1907 he was appointed professor of geography at Uppsala University. Two years later, Parliament decided that Sarek and Stora Sjöfallet should be national parks, something that mainly Hamberg should be thanked for.

Thore C.E. Fries (1886-1930) spent several years researching Lapland's vegetation. In his doctoral dissertation 'Botanische Untersuchungen im Nördlichsten Schweden' (1913), he distinguished between plant communities on the basis of a new approach used in plant-geographical studies in other Fennoscandian regions. The influence of snowcover and reindeer grazing on the vegetation was also studied.

Rutger Sernander (1866-1944) was professor of Plant Ecology in Uppsala from 1908 to 1931. The dispersal biology of plants and the development of climate and the plant world in Scandinavia were his main fields of interest. His thorough knowledge of plant communities in northern countries allowed him to give an exceptionally detailed picture of the development of vegetation in Sweden. Sernander's wide field of competence, and enthusiastic personality, resulted in his being able to assemble a group of devoted disciples, the 'Uppsala School', which enthusiastically fought to promote plant sociology during this period of 'Sturm-und-Drang' in the field of plant geography.

G.E. Du Rietz (1895-1967) was one of the more prominent disciples. He was Sernander's successor as professor in Plant Ecology, 1934-1962. Du Rietz carried out comprehensive studies ranging from the mountains to the seacoast. Algae, lichens - particularly their reproductive conditions - and mosses (Sphagnum) were given special attention.

T.Å. Tengvall (1892-1946), who studied in the Sarek district, H. Smith (b. 1889), who worked in the mountains of Jämtland and Härjedalen, and G. Samuelsson (18851944), who studied plants in the mountains of Dalarna, all followed in the footsteps of C. E. Fries.

Together with the above-mentioned researchers, mention should be made of G. Björkman (b. 1898), Th. Arvidsson (b. 1904) and especially S. Selander (b. 1891). They worked in the Pite and Lule Lappmark regions. Apart from plant ecology, Sten Selander involved himself deeply in nature management, particularly in the preservation of undisturbed mountain nature. He was also a successful lyricist.

Hugo Sjörs (b. 1915) who succeeded G.E. Du Rietz, was professor in Plant Ecology at Uppsala University from 1962 to 1980 . His scientific production is extensive, and covers a wide field. He focussed on the ecology of central Swedish mires, but also worked on several mire complexes in the mountains. Another of his research fields, of major importance for our knowledge of vegetation in 
mountain regions, concerns studies associated with water systems chosen as potential objects for exploitation, e.g. the Ångermanälv river.

Olof Rune (b. 1919) is probably one of those who, in modern times, has been of major importance to research into the flora of mountain regions in southern Lapland, which previously attracted only limited research attention. The relatively few plants throughout the entire mountain chain that show a strong dependence on a substrate influenced by serpentines and other ultrabasic rocks, were studied in his doctoral thesis 'Plant life on serpentines and related rocks in North Sweden' (1953).

Apart from the circle of researchers and explorers, the person who probably did most to spread knowledge of Sweden's northernmost regions was Selma Lagerlöf, who published 'Nils Holgerssons underbara resa genom Sverige' (Nils Holgersson's wonderful journey through Sweden). Although this was a book intended for primary schools, it also appealed to older readers. Today, the book belongs to the Swedish national literary heritage. The book's climax was hinted at already at the start (in the southernmost province of Skåne), when the wild geese with their exotic addresses were introduced to Nils: Mother Akka came from Kebnekaise, only relatively recently known as Sweden's highest mountain, Viisi came from the Ovik mountains, Kolme from Sarektjåkko, etc. Selma Lagerlöf's book has been translated into about thirty languages, and she was awarded the Nobel Prize in literature in 1909. Nils Holgersson may have given generations of readers, both Swedish and elsewhere, their only contact with the northern regions described in the book.

\section{Large-scale exploitation of mountain regions}

The growth of the industrial world during the early 20th century made great demands on access to abundant energy and efficient transportation systems. In the context of Sweden's northern mountain regions, this implied, e.g. the exploitation of hydroelectric resources in many of the large rivers, and the building of a railway to the Atlantic coast, which was always ice-free. The 'Iron-ore Railway' from Kiruna to Riksgränsen was opened in 1903, and electrified in 1915. During the summer of 1911, the stretch of the 'Inland Railway' from Gällivare to Porjus was completed, and in 1919 work started on the hydroelectric dam at Suorva on the river Stora Lule älv. The nature-protection organisation at that time, which acquiesced in the destruction of large parts of Stora Sjöfallet National Park, subsequently was subjected to massive criticism.

Spin-off effects of hydroelectric exploitation were that some inventories of a biological nature were made. A consistent feature was that fisheries biology inputs were given predominance, and that other biological studies were concentrated mainly to the littoral zones prior to regulation. It may be mentioned, for example, that a detailed

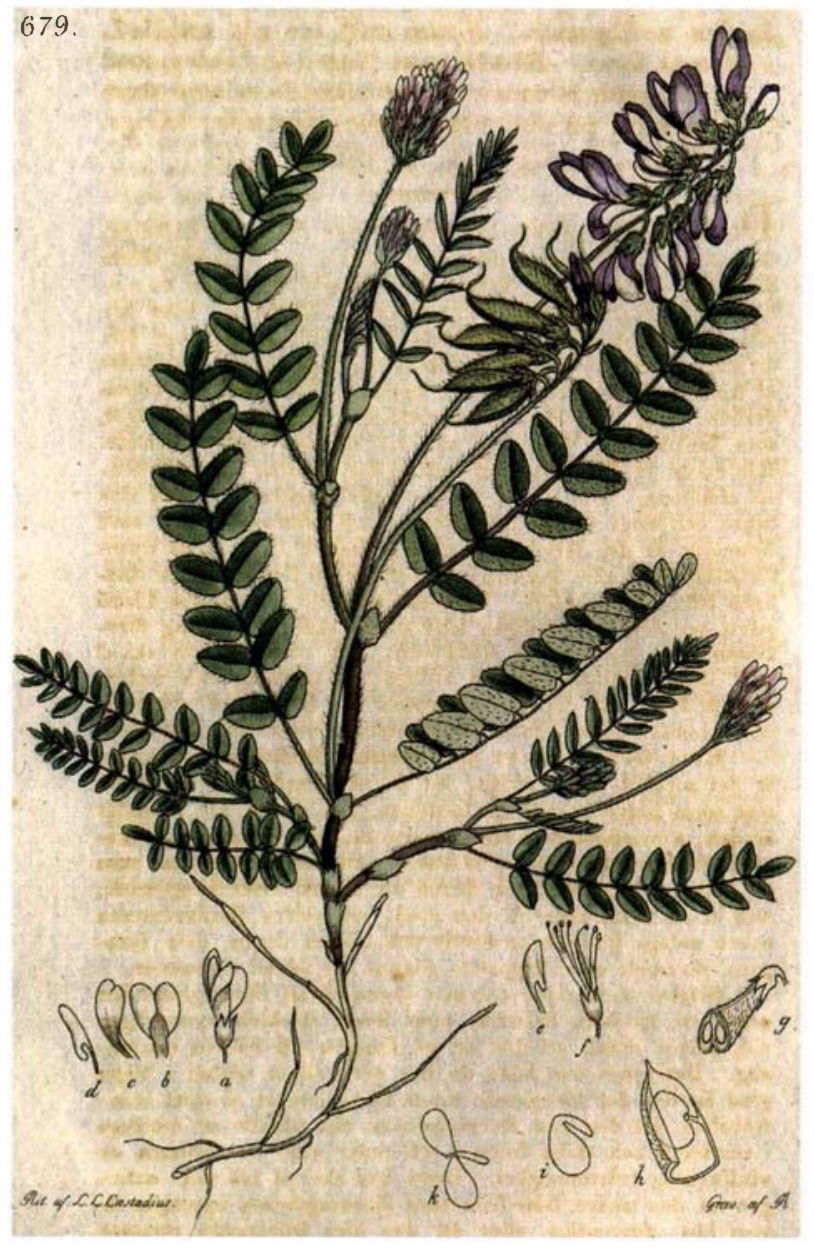

Fig. IX. Astragalus al pinus L. (Saamish duottar-saphal) 'There is no doubt that this species is one of the most palatable, and that it is among the summer delicacies of the reindeer.' Drawing by L. L. Laestadius in Wahlenberg, C. 1830.

botanical study was made at Stora Sjöfallet before the dam was built, but that the reports were not published until many years later (Björkman 1939, 1965). Changes that occurred subsequent to the completion of the four damming stages have been studied to a minor extent only.

Stora Sjöf allet National Park was considered by many to be the finest in Sweden, perhaps even in Europe, and it may be of interest to look a little closer at events leading to its establishment and subsequent fate. Most of the great rivers draining the Swedish mountains are now regulated, and in many cases the decision-making processes have been fairly similar.

In 1818, Abraham Roman gave the first relatively detailed description of Stora Sjöfallet, in his book 'Berättelser om Norrbotten och dess Lappmarker' (Tales of Norrbotten and its Lappmarks (Saami districts). This was followed in 1866 by the description given by Carl Anton Pettersson in 'Lappland dess natur och folk' (Lapland, its nature and people), and we may regard Pettersson as having, from a 
Fig. X. Stora Sjöfallet National Park. The Suorva reservoir at Suorva, seen from the 'Road to the West'. When the photograph was taken (30 September 1996), the waterlevel was fairly low. Photo: O. Eriksson.

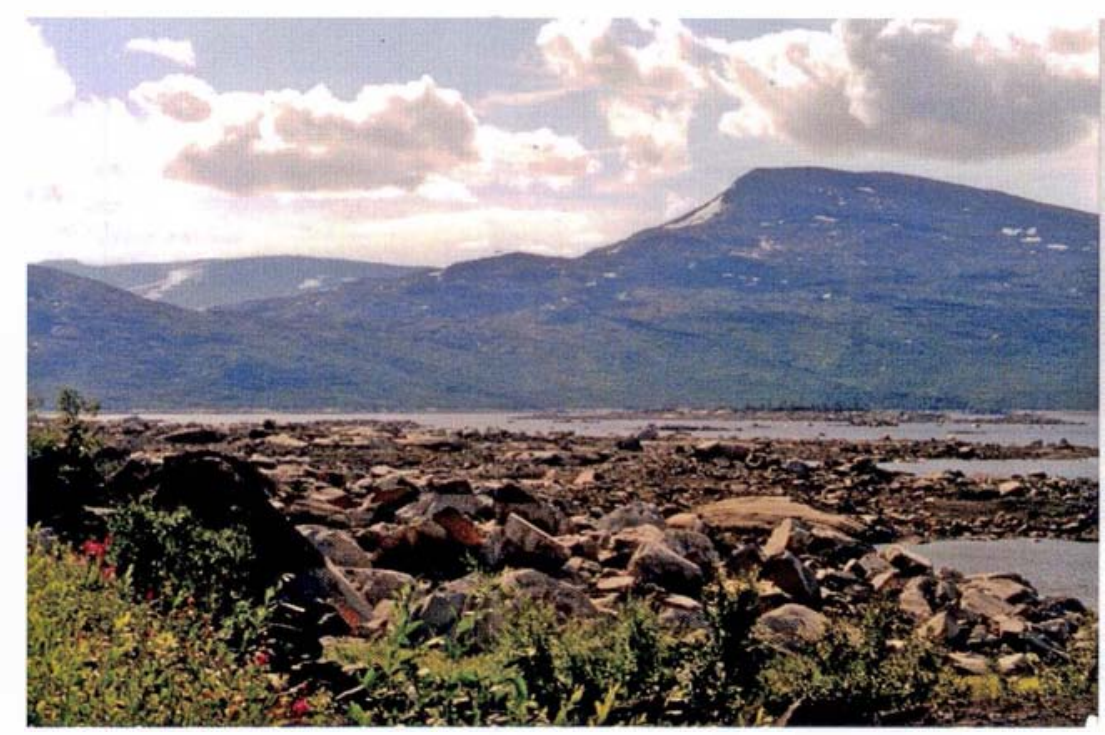

tourist's point-of-view, 'discovered' Stora Sjöfallet and the neighbouring mountains. The Swedish Tourist Association, founded in 1885, opened up the area to tourists in various ways, but sometimes in conflict with the spokesmen for nature protection. Stora Sjöfallet National Park was established in 1909, but already in 1910 work started on the Porjus power station some $85 \mathrm{~km}$ downstream. In a longer perspective, the regulation of the lake system above Porjus was almost self-evident and, as might have been expected, in 1920 Parliament decided that areas upstream that would be affected by the building of the dam and other regulation measures at Suorva should be withdrawn from the national park.

Abrahamsson (1975) summarised some of the effects of regulation as follows: 'Three of the Stora Sjöf all waterfalls are completely dry (Laestadius's waterfall, Pettersson's waterfall and Düben's waterfall), and Widmark's waterfall and Hermelin's waterfall have only modest amounts of what may be described as overspill water.'

Up to the early 1970s there were four stages during which the level between high water and low water, i.e. the regulation amplitude, was increased, to $30 \mathrm{~m}$ in the very large Suorva reservoir. Numerous smaller lakes and waterways have disappeared. As a comparison, it may be mentioned that the natural amplitude in these water systems before regulation was $3.7 \mathrm{~m}$. The water volume is about two-thirds of that in Lake Vänern. The full reservoir is estimated to be ten times greater than the natural volume at normal water level in the unregulated lakes upstream of Suorva.

On account of its size and its orientation, largely NW$\mathrm{SE}$, the reservoir is of ten exposed to severe storms, which would have been manageable for boat traffic on the smaller lakes before regulation.

Depending on the character of the shoreline, a flooding zone has been created, which varies in width from perhaps
$50 \mathrm{~m}$ to about one kilometre. Normally, there is a belt of several hundred metres' width, almost devoid of higher plants and animal life. Many species have disappeared, whereas others have been drastically reduced. For example, within the Sjöf all area there were originally 532 different vascular plant species. Of these, 367 were in areas withdrawn from the park in the first stage of regulation. Seventeen species were totallyexterminated, e.g. Rhododendron lapponicum (Björkman 1939, 1963a,b). Lindberg (1970) estimated that 50 years'exploitation in the national parks had removed the living conditions for at least 100,000 pairs of ducks, waders, small birds, etc., together with mammals and birds of prey that were affected directly or indirectly.

This exploitation of an important mountain area naturally could not take place without protest. Researchers such as Axel Hamberg, G. Einar Du Rietz and Sten Selander reacted strongly. Abrahamsson (1975) expressed surprise that the board of the Swedish Tourist Association (STF) did not express an official standpoint concerning encroachments in the park.

\section{Data for decision-making in Swedish-Norwegian rein- deer grazing conventions - new knowledge of nature in mountain regions}

The 'Lapp codicil', i.e. the addendum to a treaty between Denmark and Sweden that, since 1751, with supplements in 1883, had regulated the right of Swedish Saami to use reindeer-grazing land in Norway, came to an end in the early 20 th century (1907). It was replaced by a series of SwedishNorwegian commissions that, under Finnish chairmanship, were charged with obtaining the knowledge necessary for negotiations concerning a new convention. The work was largely conducted in the northernmost mountain region within the Karesuando and Kiruna municipalities, and in Troms county in Norway. 


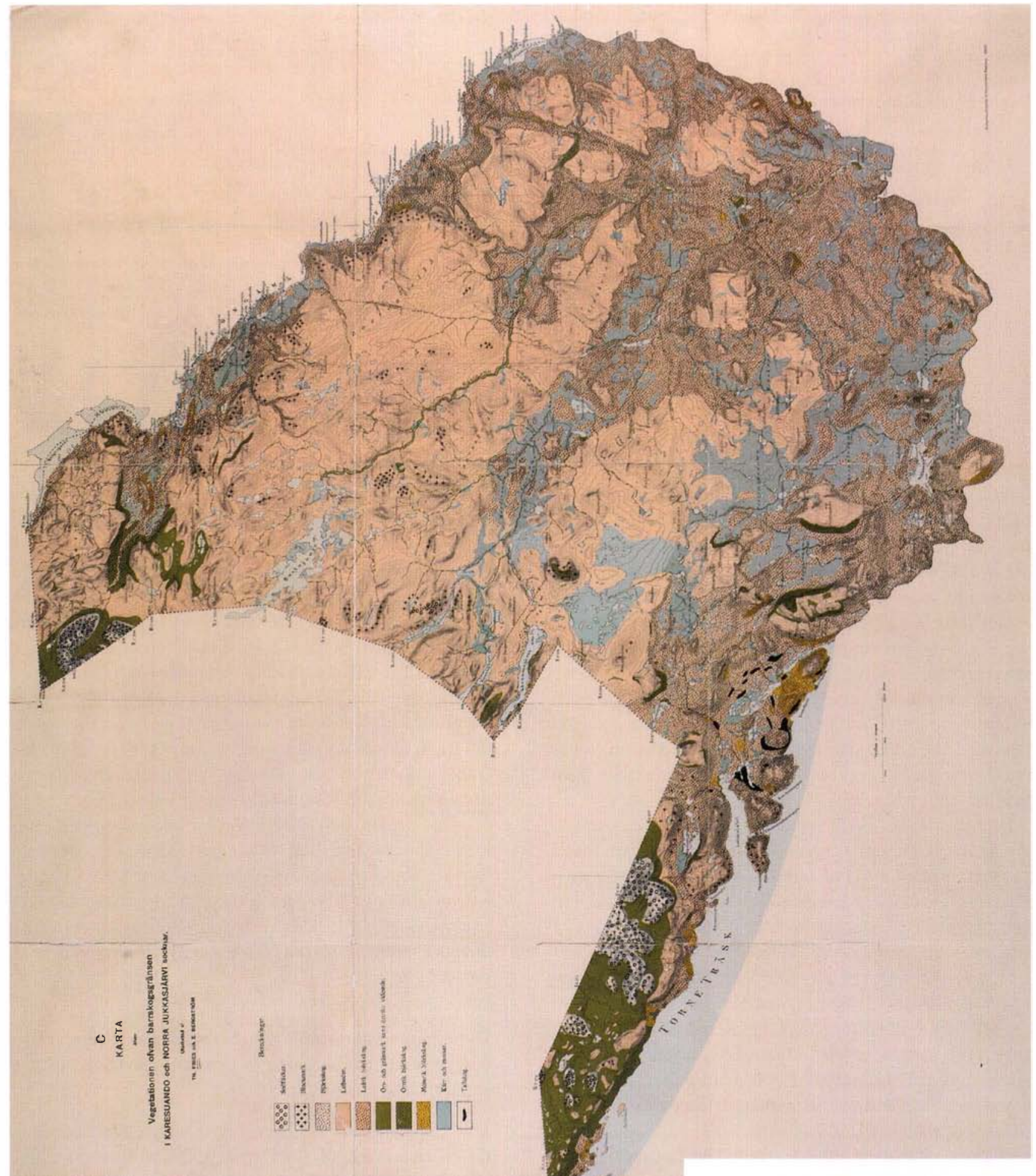

Fig. XI. Part of the map by C.Th. Fries and E. Bergström, 'Map of the vegetation above the coniferous forest limit in the parishes of Karesuando and Norra Jukkasjärvi'. Eight dominant vegetation types, as well as boulder-strewn areas and snow-patches, are included. (App. C in E. Lönnberg 1909) 
As an example of the planned work, it may be mentioned that the 1906 Reindeer Grazing Commission (Stockholm 1913) had created a picture of reindeer-grazing conditions and migration patterns across national borders, by means of interviews with Swedish and Norwegian Saami, local inhabitants and government officials.

The 1907 Commission (Stockholm 1909) focussed on the possibility of reducing Swedish reindeer herding on Norwegian territory by various measures. Information was collected during journeys along the migratory routes and in the spring and summer pastures in the mountains.

The Reindeer Commission of 1909 (Helsinki 1912) initiated the creation of the widest biological knowledge base through its own fieldwork. For two years the vegetation was studied, with emphasis on the reserves of reindeer grazing in different seasonal grazing areas. A line transect model for enumeration, adapted to make it practically applicable, was used. Great interest was shown in the phenology of forage plants, as well as in the location and nature of calving sites, together with the timing of calving.

Details of the time at which a complete snow cover became established, and of its successive thawing, and of the structural features of snow that negatively influence grazing, were also published. As an annex (originally confidential) to the 1909 court proceedings concerned with the reindeer-grazing question, a pamphlet entitled 'Om renarna och deras levnadsvanor' (On reindeer and their living conditions; Lönnberg 1909) was submitted. A vegetation map at the scale 1:200,000, showing the northernmost part of the Swedish mountain chain, drawn by Th. Fries and E. Bergström, was included. When considering the extent of the region and its inaccessibility, the compilation of this map may be regarded as a pioneering work of the highest quality. The findings of the Commission were published in six volumes.

Fries also participated in the Reindeer Grazing Commission of 1913, where cooperation was established with a working group consisting of experienced Swedish, Finnish and Norwegian researchers in the biologicalgeographical sphere. This working group conducted fieldwork in 1914 and 1915. The results were presented in 18 volumes (Stockholm, 1917). Probably none of the earlier commissions that had worked to acquire data for the reindeer-grazing conventions could have presented so much knowledge on contemporary reindeer management and on the biological conditions determined by natural conditions in the mountains, as did the 1909 and 1913 commissions. A new 'Convention between Sweden and Norway regarding the right of migratory Lapps to reindeer grazing' became law in 1919 (Svensk författningssamling 1919 , No. 895). This has subsequently been prolonged in stages. A new Convention is presently being prepared, but when it will be approved is not known.

\section{National Parks}

The National Parks in the mountains not only contribute to providing - occasionally fragile-protection to valuable natural environments, but also provide freedom for the predatory fauna. An increased frequency of visitors, and publicity, have certainly increased the awareness of the general public with regard to these important but limited regions of the mountain chain. The parks also offer the opportunity to conduct research based on long-term series, e.g. concerning relationships between weather, climatic change, vegetation and fauna. Examples are the research projects based on the Abisko Research Station (founded 1912) in the Abisko National Park and, to a lesser extent, in the adjacent Vadvetjåkko National Park.

\section{Present-day maps of the mountains}

The first practically usable maps covering the entire mountain chain are the Ordnance maps at a scale of 1:200,000. The first to be published - the Abisko map - appeared in 1886 , and by 1923 the entire mountain chain had been covered. After about 50 years, the present-day topographical maps, based on interpretation of aerial photography, have now superseded the Ordnance maps. The first of the new series covered the Kiruna area (1960-1961), and the final sheet of the mountain chain was published in 1978. The map scale is $1: 50,000$ or $1: 100,000$. These maps are substantially more reliable than their predecessors.

A map of Sweden's solid geology was published in 1958 , the same year as the map of Sweden's Soil Types. Both were published by the Geological Survey of Sweden. The National Atlas of Sweden was published in 17 volumes between 1990 and 1996. Naturally, in addition to the abovementioned general maps, numerous detailed maps of limited areas have been created over the years.

During the 1970s, a programme of aerial photography was started, covering all of Sweden on infrared film from an altitude of $9,000 \mathrm{~m}$. This material formed the basis of the 'Vegetation map of the Swedish mountains', in colour and at a scale of 1:100,000, prepared by the Department of Physical Geography, Stockholm University, by Andersson et al. in 1978-1984. This work was commissioned by the Swedish Environmental Protection Agency (EPA). The National Land Survey, Luleå, is presently working with the mapping of the remaining parts of the country, using much the same approach.

When the National Land Survey's vegetation maps finally cover areas along the borders of the mountains, which were omitted in the EPA map, the vegetation of the mountain chain may be considered to be largely known. 


\section{The reindeer}

\subsection{Origin}

The origin of the reindeer family is not fully known. However, it appears to have come from Alaska, Beringia or from the mountain regions of northeastern Asia, more than 400,000 years ago (Banfield 1961).

Flagstad \& Røed (2003) used mitochondrial DNA sequences to establish that a large and coherent population in Beringia, with dispersal far into Eurasia, appeared to be the most important origin of the genus's gene pool. In addition, there appears to have been a small, isolated refugium in western Eurasia and a larger, well-defined one to the south of the North American ice-sheet during the Wichelian/Wisconsin glaciation.

Several subspecies have become differentiated from these dispersal areas and have spread over the Old and the New World, to both boreal and to alpine and arctic areas from lat. $45^{\circ} \mathrm{N}$ (northern China) to lat. $80^{\circ} \mathrm{N}$ (the Arctic islands).

When the latest ice age began, about 190,000 years ago, the reindeer was already a pronounced feature of the European fauna. The ice had its greatest extent about 25-30,000 years ago, and the reindeer had its corresponding greatest dispersal 12-15,000 years ago. At that time, it dominated the ice-free tundra to the south of the ice, in what is today Central and Western Europe, including Ireland, England and large parts of the North Sea - at that time also tundra. The reindeer co-existed with species such as the woolly mammoth, hairy rhinoceros, musk ox, cave bear, cave hyena and arctic fox. The reindeer has managed to survive the demise of most of its contemporary species.
The reindeer was an important source of nutrients, both for the Neanderthals ca. 50,000 years ago, and for the Cro-Magnon people ca. 25-30,000 years ago, as evidenced by finds of bones and artefacts from ancient dwelling places. Cave paintings in the Dordogne, France, and at Altamira, Spain, are excellent examples of Palaeolithic art at its peak during the Magdalenian period 13,000 years ago, and indicate the great importance of reindeer to the peoples of that time.

A period with relatively mild climate occurred about 16,000 years ago, and the ice began to recede towards the north. Southern Sweden became ice-free about 10,000 years ago, and after a further 1500 years, it had been reduced to a small remnant in Northern Sweden.

The reindeer, and other species we find today in the mountain fauna, e.g. certain rodents, the arctic fox and ptarmigan, followed the ice as it receded. Immigration to Scandinavia took place during the later part of the 'Dryas period' about 12,000 years ago. The Närke Sound, linking the Yoldia Sea with the Atlantic, cut off the Scandinavian peninsula about 9,000 years ago and affected the expansion of the fauna towards the north. Reindeer were, however, common on the Scandinavian tundra during the Allerød period (12-9,000 years ago). The tundra period came to an end with a warm period about 9-8,000 years ago, resulting in the rapid establishment of coniferous and deciduous forests and in the development of a fauna consisting of elk, red deer, beavers and forest birds. Both humans and reindeer moved successively towards more high-altitude and nutrient-poor regions.

The melting of the land ice, especially in areas of north-

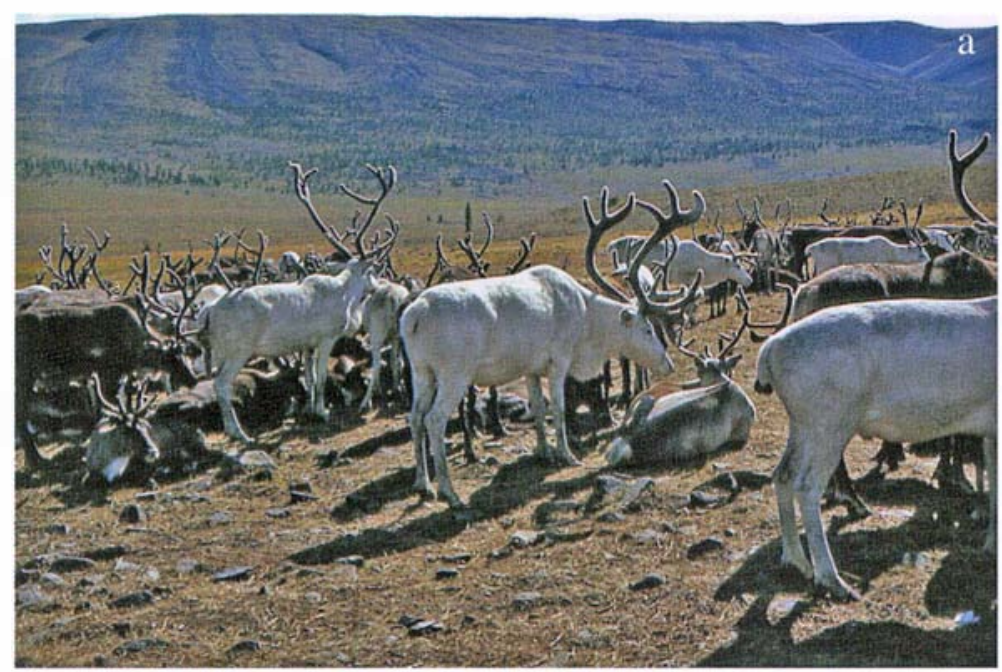

Fig. XII. The genus Rangifer occurs in a number of forms in the northern hemisphere, e.g.

a. Rangifer tarandus tarandus east of SebenKeul, Verkhoyansk Mountains, Republic of Sakha (formerly Yakutia). Photo: O. Eriksson, September 1973;

b. Rangifer tarandus tarandus at Tavvavuoma, Lainiovuoma Saami village, Swedish Lapland. Photo: O. Eriksson, 10 August 1973;

c. Rangifer tarandus groenlandicus at Rävsjön, S. Strömfjord, Greenland. Photo: O. Eriksson, 17 August 1978;

d. Rangifer tarandus platyrhynchus, female with calf, Svalbard. Photo: Anon. 

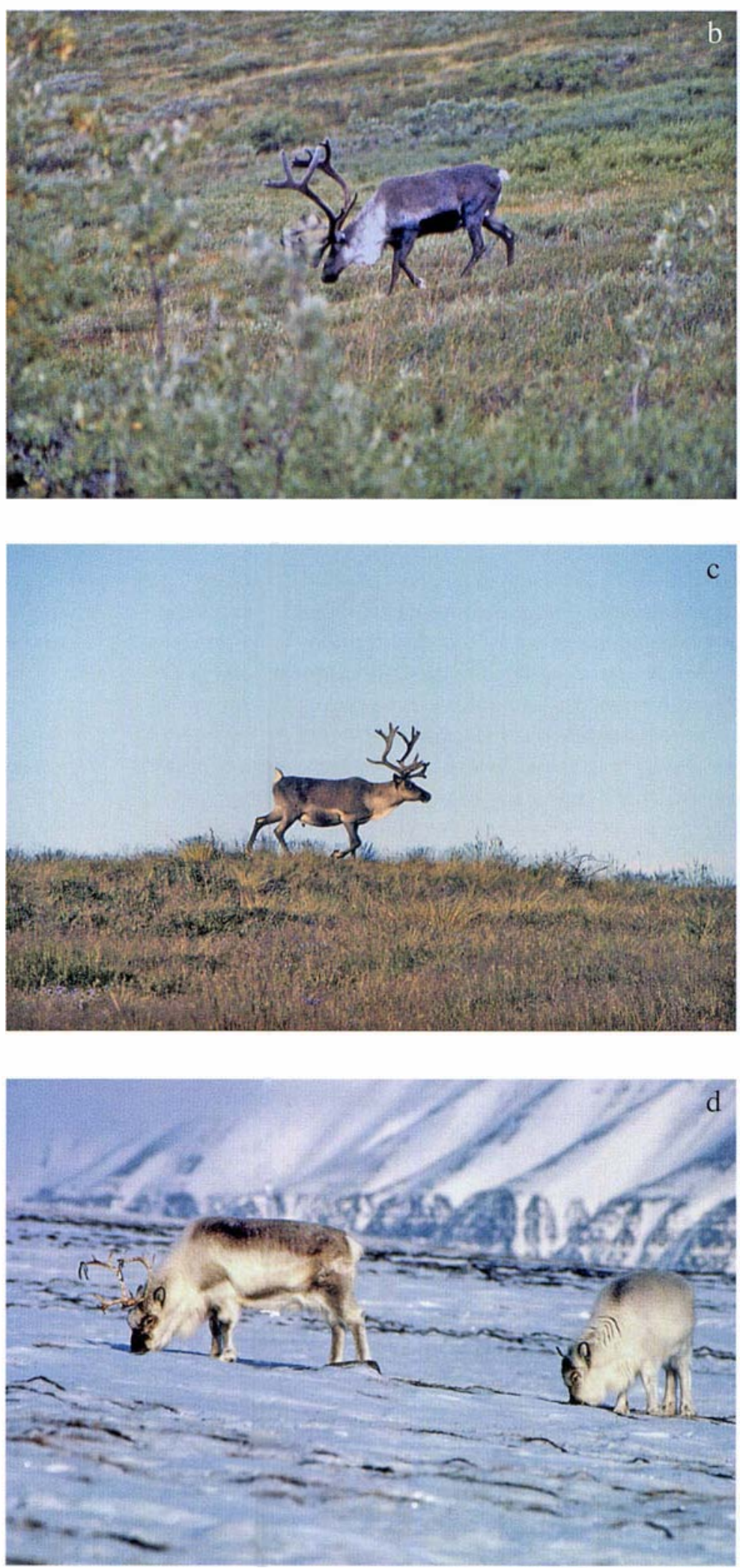


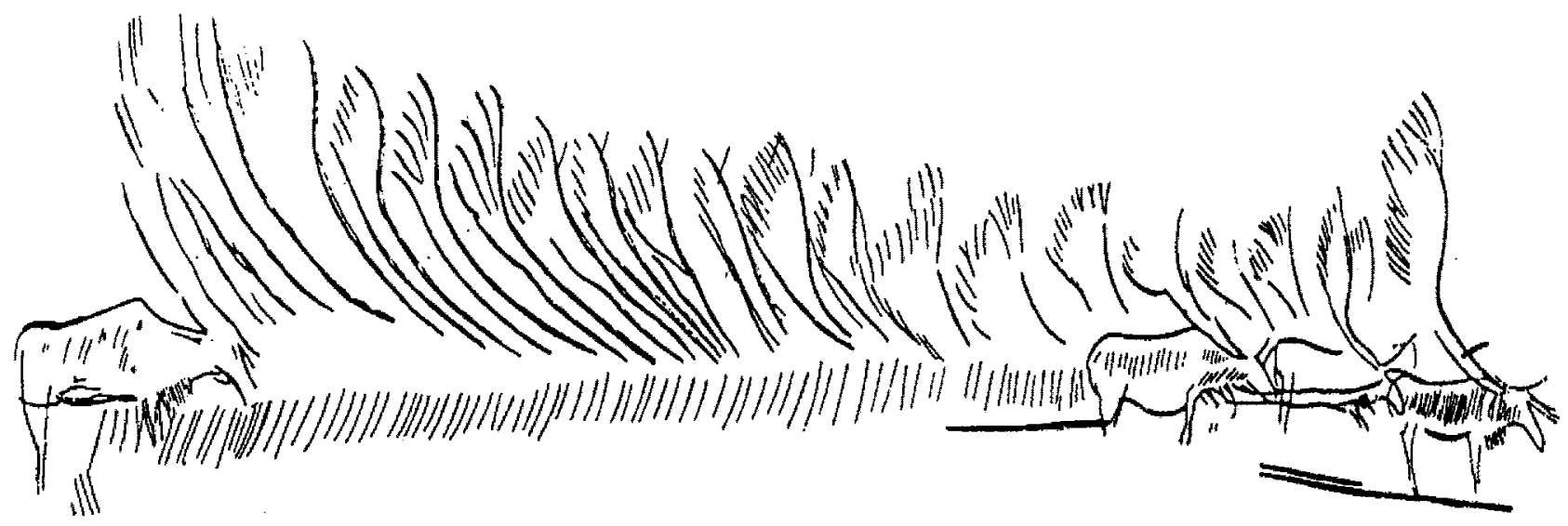

Fig. XIII. A reindeer herd depicted ca. 10,000 years ago on a cave wall at Teyjat, France. The impression of a large number of animals in rapid motion is striking.

ern Fennoscandia that melted early, probably permitted the immigration of the tundra reindeer from the east, together with the hunters who depended on them. Wild reindeer were now numerous also in the northernmost parts of the Scandinavian peninsula, and along the mountain chain down to Säma and Idre in Dalarna. However, their numbers decreased with time, depending on intensive hunting by meat-demanding settlers as well as by Saami who wanted to exterminate wild reindeer, which caused disorder by mixing with the domesticated herds. The last wild reindeer in Dalarna were shot during the 1860s-1870s, whereas in Norrbotten, they had probably already disappeared during the 1830s (Lönnberg 1909). However, in the southern parts of the Norwegian mountains, e.g. Setesdal Vesthei,

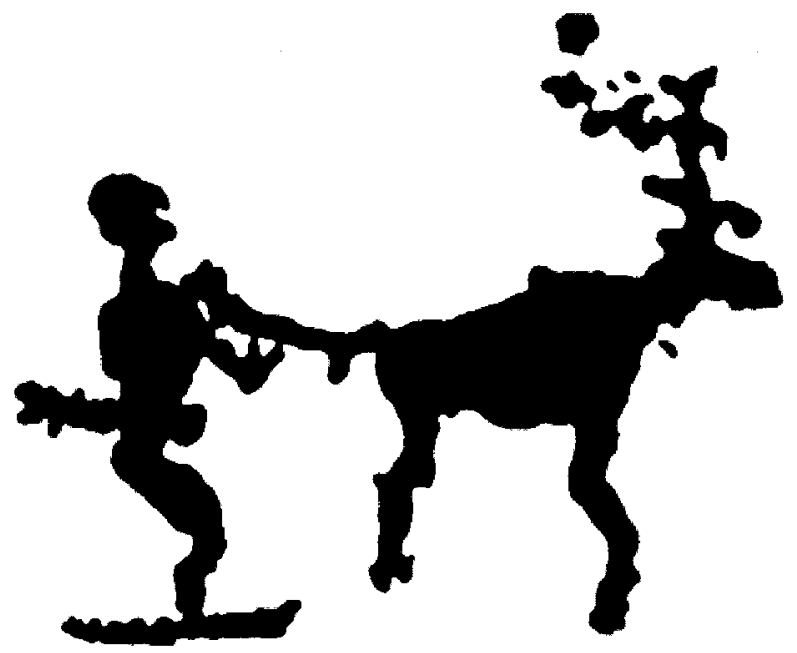

Fig. XIV. Man and reindeer in an early rock-engraving at Zalavruoga, coast of the White Sea, Russia. A possible indication of an early migration from the east. After Skjenneberg \& Slagsvold (1968).
Hardangervidda, Ottadalen, Snöhetta and Rondane, there still remain populations of wild reindeer, living under strictly regulated conditions.

The Scandinavian domesticated reindeer, both the mountain reindeer and the forest reindeer, can trace their main origin to the Eurasian tundra reindeer, Rangifer tarandus tarandus L., which was described and named by Linnaeus in 1758 . However, Hollsten (1774) reported that, during the 18th century, there were wild forest reindeer of a different breed in the taiga around the Gulf of Bothnia. These reindeer were reported to be much larger than the mountain reindeer, and had a darker coat. During the mating period they moved farther to the west from the coastal regions into the area of the Lappmark (Saami territory), where there were domesticated reindeer based on $R$. tarandus tarandus $\mathrm{L}$. This intermingling might explain why some of the domesticated 'forest' reindeer, at least in the early 20th century, were somewhat larger than the domesticated 'mountain' reindeer.

The wild forest reindeer (Rangifer tarandus fennicus Lönnberg) gradually was exterminated within most of its northern range up to the end of the 19th century. In eastern Finland, Karelia and neighbouring regions of Russia, however, an increasing population still remains (Siivonen 1975, Nieminen 1980).

Nonetheless, Lönnberg believed that descendents of the wild forest reindeer described by Hollsten (1774) were to be found among the semi-wild 'domesticated' forest reindeer belonging to Sjocksjock's Saami village in the eastern part of Jokkmokk parish. These were renowned for their size and attractive appearance, e.g. as mentioned in 'Proposals for regulations concerning the Swedish Lapps and settlers in Sweden', a report published in Stockholm by a Parliamentary Committee. (Förslag till Förordning angående de Svenska lapparne och de bofasta i Sverige 1883)

Sjockjock's Saami village was split in 1903 and amalgamated with the Jokkmokk and Gällivare forest Saami 
villages. In 1945, Jokkmokk was amalgamated with Serri and Udtja. The Rödingträsk group in Udt ja village became famous for their reindeer, which were much larger than those normally found in other Saami villages. Lönnberg (1909) observed them in the field, interviewed reindeer owners and conducted taxonomic investigations, including craniometric studies. Unfortunately, his material was limited. His conclusion was that the Rödingträsk population of domesticated forest reindeer, although diluted, probably originated from $R$. tarandus fennicus Lönnberg, the Finnish-Karelian subspecies, whereas the domesticated mountain reindeer were taxonomically identical to $R$. tarandus tarandus, as well as the domesticated 'forest' reindeer farther south in the reindeer-management area, e.g. Mausjaure or Malå.

Espmark (1981) studied the taxonomic relationships between the domesticated mountain and forest reindeer in Sweden. Skull as well as antler measurements were made. The material studied consisted of more than 800 skulls collected during the early 1950s from most of the reindeer-management area, and stored in the Swedish Museum of Natural History. Espmark's report does not reveal whether efforts were also made to include material from the Rödingträsk population. His conclusion was that the two groups of domesticated reindeer are not completely identical, but that the differences are not as distinct as as- serted by Lönnberg (1909). We can only speculate about the conclusion he might have reached, had the material included reliably identified Rödingträsk skulls. Experienced reindeer herders (pers. comm. Stefan Mikaelsson, Rödingsträsk andApmut-Ivar Kuol jok, Sirkas) assert that it is still possible to distinguish reliably between descendents of the ancient Rödingträsk line by sight. Regardless of any conclusions reached, a study of family relationships between domesticated mountain reindeer, 'normal' domesticated forest reindeer, the Rödingträsk type and wild Finnish forest reindeer ( $R$. t. fennicus), as inferred from mitochrondrial DNA sequences, would be illustrative.

\subsection{Reindeer feeding}

As an herbivore, the reindeer is a fastidious generalist and opportunist, searching for the most valuable grazing available while constantly on the move, generally against the wind, and consuming what it finds with great finesse. Its menu consists of most of the alpine and forest flora; thus examples are given only occasionally in what follows.

The types of vegetation used in mountain reindeer husbandry, principally during spring, summer and autumn, are all within the year-round territories where the Reindeer Husbandry Act of 1977 is applied throughout

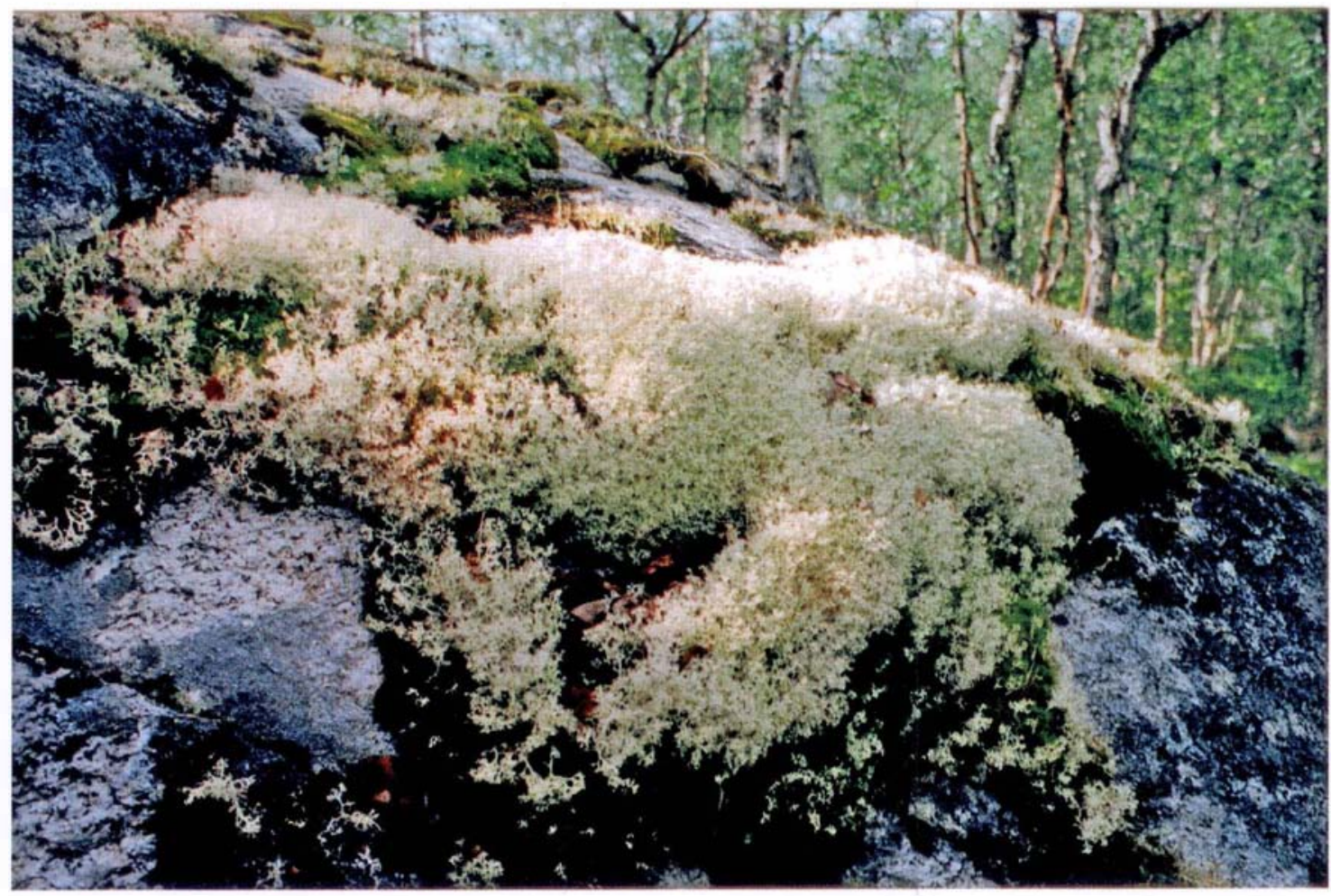

Fig. XV. Even on sites exposed to heavy grazing pressure, patches with abundant lichen growth can be observed. Topography, snowdepth, etc., limit access to such sites by the reindeer. Cladina or Cladonia spp. On steeply inclined slabs in the Birch forest heath type with mosses east of Seukokjaure, Sörkaitum Saami village. Photo: O. Eriksson. 15 July 1998. 


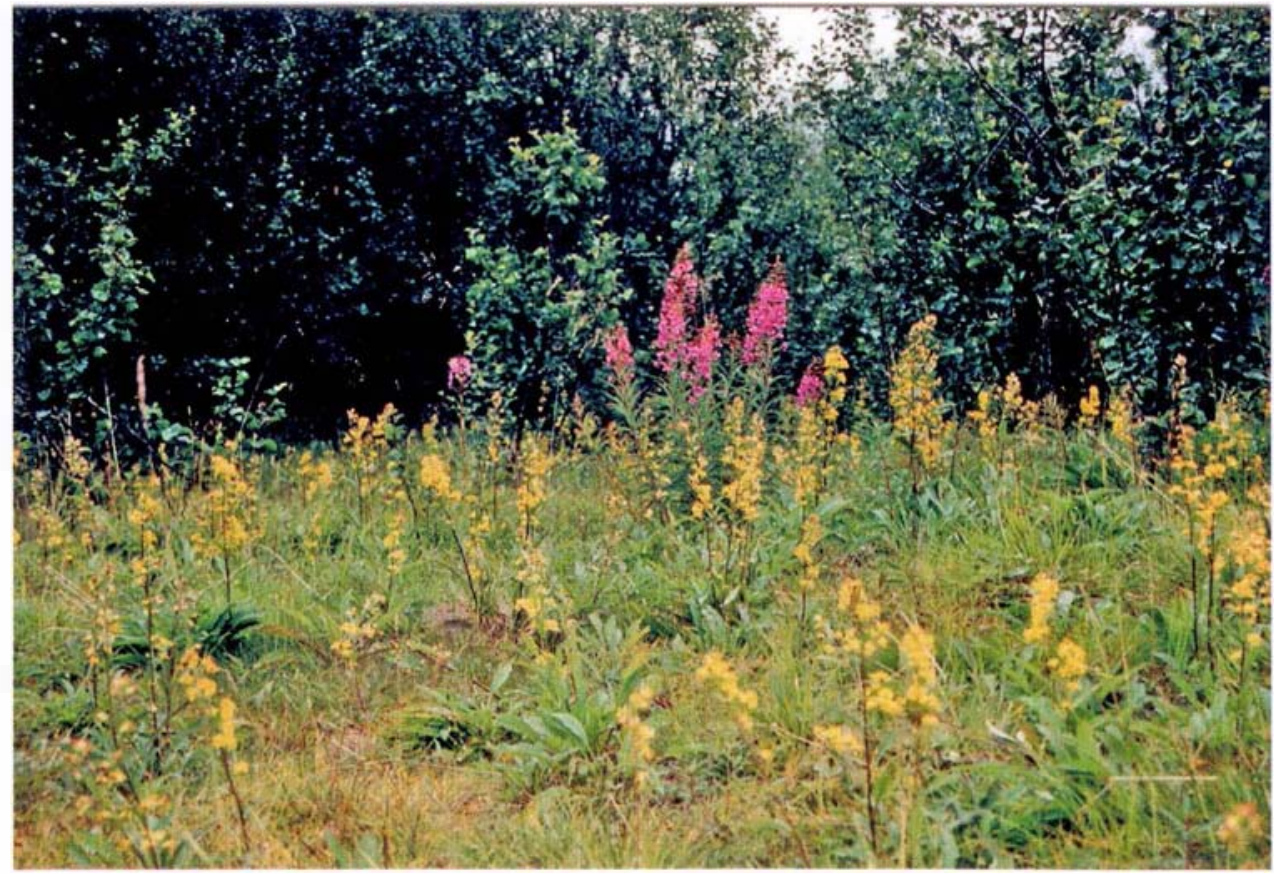

Fig. XVI. Among other species, Epilobium angustifolium and Solidago virgaurea (Saamish horbmá and beatnatnjuovččarassi) are in bloom at the height of summer, providing high-quality forage near the tree line. Birch forest heath type with mosses, east of Seukokjaure, Sörkaitum Saami village. Photo: O. Eriksson, 1 August 1997.

the year (Geijer 2003), and in the low-alpine belt and the upper parts of the subalpine mountain birch woodlands. The types of vegetation included in the present study can all be found within these zones.

The tree limit (Saami: orda) is one of the most important natural lines of demarcation that influence the presence of reindeer (O. Blind, P. Idivuoma, pers. comm., Ruong 1982). The low-mountain area at higher altitudes provides early grazing on thawed summits and southern slopes, as well as on the sheltered, yet easily monitored and fairly regularly used calving grounds. However, the grazing there is of ten sparse. Lichens such as Cetraria spp., Cladonia spp., Cladina spp., Sterocaulon spp., and shrubs such as Arctostaphylos spp., Vaccinium spp., Empetrum hermaphroditum and last-year's grasses, dominate initially (Lönnberg 1909, Palo 1981). Betula nana has somewhat of a special status as a grazing plant. The top shoots are cleaned of bark, buds and young leaves. The twigs are broken off more or less where wood and bark make up roughly similar amounts of biomass. Traces of grazing are seen in the white-scraped remaining twigs.

As the spring and early summer progress, fresh grazing of graminaceous plants becomes available, e.g. Festuca ovina, Deschampsia cespitosa, D. flexuosa, Anthoxanthum odoratum, A. odoratum subsp. alpinum, Phleum al pinum, $J$ uncus trifidus and Carex bigelowii. Thawed stretches of wetland and springs provide species such as Eriophorum vaginatum, Angelica archangelica, Menyanthes trifoliata and sedges. Roots and rhizomes are also grazed. Wil- lows (Salix spp.), especially those that have more or less green, non-hirsute, leaves, such as Salix phylicifolia and S. hastata, have great value for grazing in the early stages, and are considered to be among the most attractive (L. Baer, P. Idivuoma, pers. comm., O. Eriksson unpubl, Warenberg et al. 1997). Willows of similar value, but developing later and smaller in size, are $S$. reticulata and $S$. herbacea, the occurrence of which can, to some extent, be associated with thawed snowdrifts.

\section{Pastures in the mountain birch woodlands}

The mountain birch woodlands (close to the tree limit) provide protection in bad weather and both lichen and green grazing during the snow-free period. Here can be found more or less the same grazing plants as within the low alpine zone. Mountain birch leaves provide a considerable nutrient supplement and, in addition, a number of nutritious herbs flower during July-August, e.g. Epilobium angustifolium, Melampyrum sylvaticum, Solidago virgaurea, and Cicerbita alpina. These plants are of great importance, and are grazed when the myriads of insects permit.

Fungi such as Leccinum versipelle, L. rotundifolia, Suillus bovinus, S. variegatus and Lactarius trivialis are searched for and grazed intensively during the late summer and early autumn (Lönnberg 1909, Sk jenneberg \& Slagsvold 1968, O. Eriksson, unpubl.). Dry fragments can even be identified in rumen contents from the winter-grazing period. However, the moisture content of fungi is high 


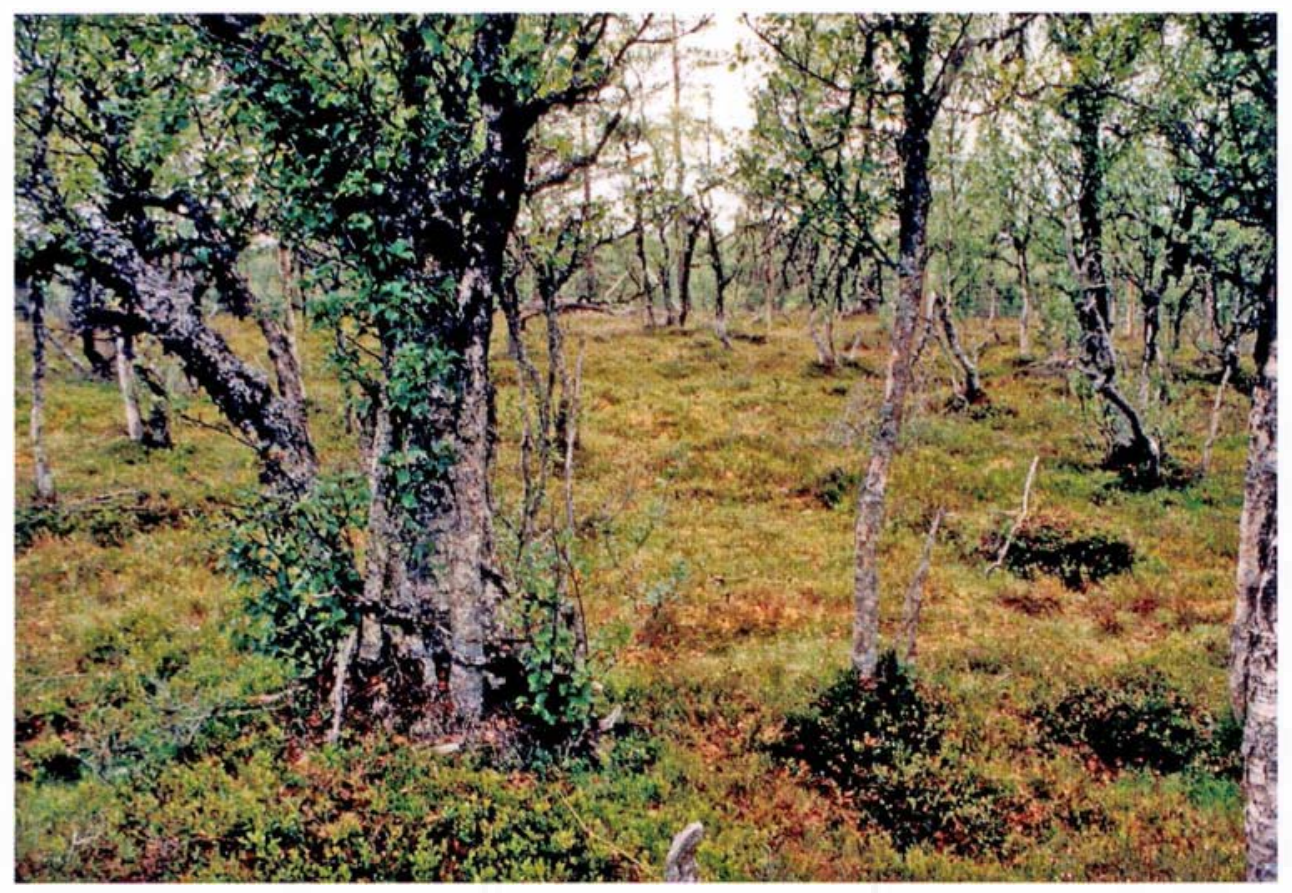

Fig. XVII. If the ground-lichens are inaccessible to the reindeer, tree lichens becomeimportant as a food source. Intensive grazing on birch can, however, lead to digestive problems, because fragments of birch bark are ingested and accumulate in the digestive canal (personal communication, Lars Baer). Birch forest heath type with mosses and scattered Pinus sylvestris. Långfjället, Idre Saami village. Photo: O. Eriksson, 15 July 1998

(ca. 90\%) and the content of essential nutrients is low. The proteins that are present are principally enzymes, of high quality owing to their content of all essential amino acids. In addition to large amounts of phosphorus and potassium, many fungi have valuable concentrations of calcium, zinc, iron, manganese and selenium. The partiality of reindeer for a diet of fungi is probably conditioned by the mineral content (Skjenneberg \& Slagsvold 1968, Holmberg \& Marklund 1996).

Apart from the migrations from winter to summer grazing areas via the spring and autumn grazing pastures, an altitudinal migration can be seen in the mountain area of some Saami villages. This extends from the spring pastures of the low-alpine zone, down to the early-thawed pastures along valley bottoms below the forest limit, and then moves upwards following the thaw and budbreak, driven by the hatching of mosquitoes (O. Blind, pers. comm.).

Within the summer-grazing area, there is a daily altitudinal migration, between good pastures in the valley bottoms, and resting places on snow-patches or on windswept summits, where the reindeer find cool conditions and a minimum of irritating insects (Kuhmunen 1974).

The reindeer normally make use of the plant communities close to the tree limit during the snow-free period, partly during a rather short period, connected with the traditional reindeer migrations between winter and summer areas during the calving period in May, and partly during the autumn, when the herd is often left to graze more or less freely.
In years when weather conditions (i.e. snow) make it impossible to move to, or to remain in, the winter-grazing areas, the spring and autumn areas may also be used as winter grazing. The lichens and shrubs associated with the ground layer are now supplemented by epilithic lichens, such as Cetraria hepatizon, Hypogymnia alpicola, $H$. intestiformis, Parmelia centrifuga and P. saxatilis. The grazing of epilithic lichens can be detected through the wear caused by mineral particles, which appears to have a disastrous effect on the front and eye-teeth of the lower jaw, thereby shortening the life of the animal (Skuncke 1958, Sk jenneberg \& Slagsvold 1968).

The tree layer contains epiphytic lichens. On the branches of the mountain birch, the most common lichens are possibly Cetraria sepincola and Bryoria simplicior, whereas on the trunks the lichen that is most clearly visible is Parmelia olivacea, owing to its deep olive-green to brown-black colour. It is abundant above the level that it generally covered by snow during the winter. Other frequent species are Parmelia sulcata and Physcia stellaris.

The intensive utilisation almost throughout the year of plants sensitive to wear-and-tear is likely to have a destructive effect on the vegetation, which consists of many species with long regeneration periods. 


\subsection{Fertility}

Skuncke (1973) reported that $80 \%$ of the female reindeer in the reindeer research herd normally gave birth to a calf annually, from their second year of life until their tenth or thirteenth year. Skjenneberg \& Skogsvold (1968) reported $70-80 \%$ calving by Norwegian domestic reindeer in the same age interval.

\subsection{Diseases}

The reindeer's mode of life, the relatively sparse groups or herds present in large areas, and the length of time during the year for which the ground is covered by snow or ice, result in the most common diseases' being of minor importance (Berglöf 1923, Skjenneberg \& Slagsvold 1968). Infectious diseases can, however, become a major problem if the reindeer are kept under more intensive management or confined in pens. The Reindeer Grazing Convention of 1919 (Svensk författningssamling 1919 N:r 895 § 158-167), provides information on how epizootia such as reindeer plague, reindeer disease, anthrax and infectious hoof disease should be dealt with when Swedish reindeer graze in Norway. Reindeer plague (Pestis tarandi) is a disease that occurred frequently during the 18 th and 19 th centuries. In the mid-1760s, there was a particularly severe outbreak in the reindeer herds. Many Saami lost almost all their reindeer, and began instead to fish in the Norwegian fjords. As a result, the population in Jukkasjärvi was reduced over a 25-year period, from 1300 persons to fewer than 900 (Ruong 1982). In 1896, thousands of reindeer died in northern Lapland, probably because of an infection with Clostridium septicum (Skjenneberg \& Slagsvold 1968, Rehbinder \& Nikander 1999). In 1911, reindeer plague broke out in the Arjeplog mountains, killing the entire calf population (Ruong 1982).

Reindeer pasteurellosis (Septicaemia haemorrhagia) is caused by bacteria belonging to the Pasteurella group. In 1912 and 1913, there were severe outbreaks, extending fromArjeplog northwards. Between one and two thousand reindeer died. In 1924, there were outbreaks in Jämtland. The summer of 1959 was exceptionally hot and dry in southern Scandinavia. Several hundred reindeer, most of them calves, died on account of pasteurellosis in about the same areas as were affected by the 1912-13 outbreak. In one Saami village, the losses amounted to $70 \%$ of the one-year-old calves (Skjenneberg \& Slagsvold 1968).

Contagious hoof disease, caused by infection with Fusobacterium necrophorum, was a common disease of reindeer during the days of intensive management (Rehbinder \& Nikander 1999). Linnaeus wrote in Iter lapponicum (1732) about this disease in the mountains of Lapland. The Saami name 'slubbo' refers to the swollen foot and means, quite simply, 'club'. The infection can also affect other organs and parts of the body, causing severe necrotic lesions that of ten contribute to the death of the animal. In the Gällivare district between two and three thousand reindeer died during the summer and autumn of 1866 (Skjenneberg \& Slagsvold 1968).

Anthrax is a serious bacterial disease that afflicts many species of herbivorous animal. It is caused by Bacillus anthracis. Mortality among untreated animals is $5-20 \%$. The disease has not been verified with certainty on reindeer in Scandinavia. In Russia, a number of severe reindeer epizootia have been confirmed as anthrax. For example, there was a massive outbreak on the Jamal peninsula in 1911, when more than 100,000 reindeer died (Dratjinski 1914, Skjenneberg \& Slagsvold 1968).

Brucellosis is a disease that affects many different species of animal, including man. There are various $\mathrm{Bru}$ cella species; the one that causes disease and abortions in reindeer is Brucella suis biotype 4, earlier named Brucella rangifer. Brucellosis occurs in most areas where reindeer are found, but not in the Nordic countries. The disease is a problem for reindeer husbandry, on account of its stealthy development and continuous losses, but also because it is a zoonotic disease (Rehbinder \& Nikander 1999).

Among parasites that cause disease in reindeer, the meningeal worm, Elaphostrongylus rangiferi, is the one capable of causing the largest losses. Eggs and larvae are transported through the veins to the spinal cord and beneath or within the cerebral membranes. Locomotion disorders occur, leading to the death of the animal. In some years there are large losses among calves, but also among adults (Rehbinder \& Nikander 1999).

Air-borne pests, such as mosquitoes, gnats, horseflies, skin warble (Hypoderma tarandi), and throat warble ( $\mathrm{Ce}$ phenemyia trompe) are assumed to be well known and are not discussed further here.

\subsection{Mortality}

All efforts to calculate the number of reindeer that die each year suffer from large errors in the source material, and thus provide rather unreliable results. The original experimental method was to search for carcasses in the field, which, for practical reasons, is never $100 \%$ reliable. During the summer, carcasses disappear rapidly, e.g. because of drowning, predators or scavengers. During winter, the snow cover may hide a carcass (Haglund 1966, 1968, Bjärvall et al. 1990). Radiotelemetry, i.e., searching by means of radio signals from reindeer fitted with transmitters, has been used in research in the Saami villages of Umbyn and Jåkkåkaska, but for economic reasons, only a few animals could be used (Bjärvall et al. 1990).

As regards adult reindeer, studies in Umbyn and Jåkkåkaska Saami villages gave the result that, among females, annual mortality is probably ca. $2.8 \%$ (Bjärvall et al. 1990). 
Table 1A. Reindeer killed by predators in the study areas and in Sweden in 1986 - 1994 (Nilsson, 2004)

\begin{tabular}{|c|c|c|c|c|c|c|c|c|}
\hline Saami Village & $1986 / 87$ & $1987 / 88$ & $1988 / 89$ & $1989 / 90$ & $1990 / 91$ & $1991 / 92$ & $1992 / 93$ & 1993/94 \\
\hline Lainiovuoma & 20 & 10 & 59 & 22 & 51 & 107 & 52 & 123 \\
\hline Saarivuoma & 104 & 90 & 85 & 65 & 483 & 155 & 6 & 209 \\
\hline Mellanbyn & 26 & 61 & 125 & 64 & 114 & 33 & 70 & 113 \\
\hline Sörkaitum & 38 & 243 & 214 & 179 & 311 & 85 & 328 & 132 \\
\hline Mittådalen & 461 & 558 & 381 & 760 & 318 & 340 & 470 & 176 \\
\hline Idre & 32 & 67 & 149 & 179 & 28 & 10 & 10 & 26 \\
\hline Total in Sweden & 5012 & 6859 & 6910 & 8252 & 9030 & 8152 & 12495 & 5491 \\
\hline
\end{tabular}

Table 1B. Reindeer killed by predators in 1993/1994 divided among study areas, reindeer gender and/or species of predator (Nilsson 2004).

\begin{tabular}{|c|c|c|c|c|c|c|c|c|c|c|c|}
\hline Saami Village & Male & Female & $\begin{array}{l}\text { Adult, } \\
\text { unknown } \\
\text { gender }\end{array}$ & Calf & $\begin{array}{l}\text { Unknown } \\
\text { age and } \\
\text { gender }\end{array}$ & Wolverine & Lynx & Bear & Eagle & $\begin{array}{c}\text { Unknown } \\
\text { predator }\end{array}$ & Total \\
\hline Lainiovuoma & 87 & 12 & - & 24 & - & 110 & 4 & 2 & 5 & 2 & 123 \\
\hline Saarivuoma & 138 & 21 & 11 & 37 & 2 & 199 & - & 1 & 6 & 3 & 209 \\
\hline Mellanbyn & 51 & 23 & - & 39 & - & 82 & 21 & - & 10 & . & 113 \\
\hline Sörkaitum & 78 & 12 & 6 & 40 & 1 & 82 & 37 & - & 11 & 2 & 132 \\
\hline Mittådalen & 42 & 12 & - & 112 & 4 & 9 & 141 & 4 & 21 & 1 & 176 \\
\hline Idre & 9 & 6 & - & 11 & - & - & 24 & 2 & - & - & 26 \\
\hline
\end{tabular}

Calf survival is strongly influenced by the condition of the reindeer cows, which is governed, e.g. by access to, and quality of, grazing both before and during pregnancy (Rehbinder \& Nikander 1999). Factors such as late arrival at the calving areas, low temperatures, precipitation, longlasting snow cover, difficulty in fording swollen rivers when the thaw is late, as well as predation, strongly affect the survival of new-born calves (Bergerud 1980, Reimers 1989, B järvall et al. 1990). When the first problems in life have been successfully overcome, the calf must then find access to the right sort of forage in sufficient amounts during the following autumn and winter.

The results of the study of reindeer losses in Umbyn and Jåkkåkaska Saami villages (Bjärvall et al. 1990) indicate that annual calf mortality during 1982-1986 was, on average, $13.1 \%$ in Jåkkåkaska and $13.5 \%$ in Umbyn. In Jåkkåkaska, predators were responsible for $66 \%$ of these losses, and in Umbyn the corresponding figure was $75 \%$. Among calves that die during the summer, $60 \%$ are the result of predation and $15-20 \%$ are due to illness, drowning, starvation, etc. (Rehbinder \& Nikander 1999). The Board of Agriculture estimates that annual losses of adult animals in Swedish reindeer husbandry amount to $10 \%$. Half of the animals lost die during the summer (Lantbruksstyrelsen 1985). However, in 1988 predators killed 58,000 reindeer (Svensk rennäring 1999).

The extent of predation over time is very difficult to estimate with acceptable precision, on account of the dif- ficulty to find all carcasses. The cause of death can probably be determined with much greater reliability (Rehbinder \& Nikander 1999, Bjärvall et al. 1990). Compensation from the State for reindeer killed by predators was paid up to 1993/94 on the basis of carcasses found. From 1994/95, compensation has been based upon the number of bears, wolverines, lynxes and wolves within each Saami village (Svensk rennäring, 1999).

\subsection{Slaughter}

The slaughter percentage in Swedish reindeer husbandry varies with time and is decided by, e.g. the preferences of the owners, the requirements of the market and the

Table 1C. The total grazing area in the Saami villages and the maximum number of reindeer allowed (Svensk rennäring 1999*, Swedish-Norwegian Reindeer Grazing Commission of $1964^{\dagger}$ ).

\begin{tabular}{lcc}
\hline Saami village & $\begin{array}{c}\text { Area } \\
\left(\mathrm{km}^{2}\right)\end{array}$ & $\begin{array}{c}\text { Max. no. of } \\
\text { reindeer } 1988\end{array}$ \\
\hline Lainiovuoma & 3497 & $10500^{\dagger}$ \\
Saarivuoma & 3513 & $7000^{\dagger}$ \\
Mellanbyn & 3355 & $7000^{*}$ \\
Sörkaitum & 4879 & $8000^{*}$ \\
Mittådalen & 3902 & $5000^{*}$ \\
Idre & 2883 & $2700^{*}$ \\
\hline
\end{tabular}



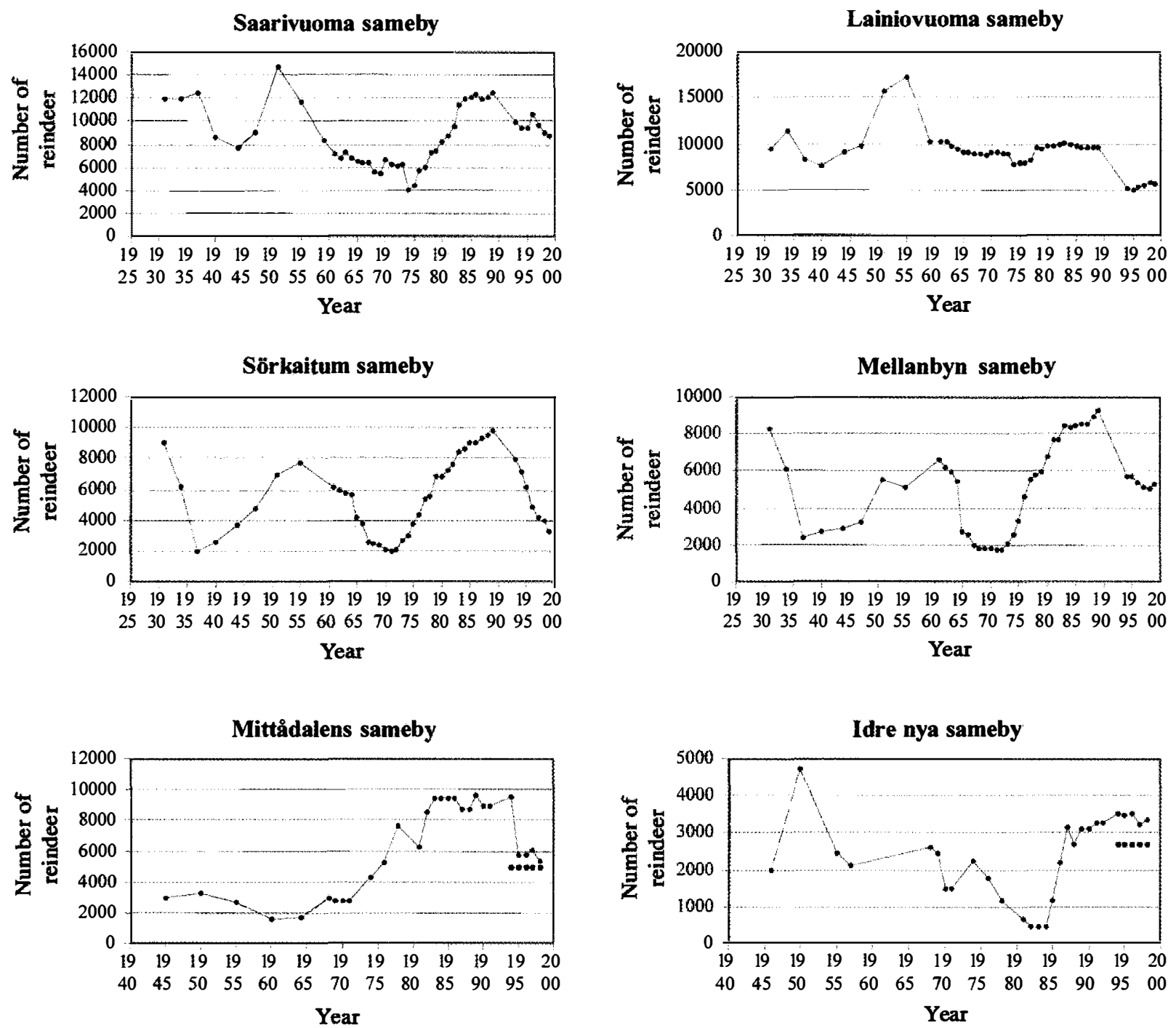

Fig. 1a. Number of reindeer in the winter population during most of the 20th century within the Saami villages Saarivuoma, Lainiovuoma, Sörkaitum, Mellanbyn, Mittådalen and Idre new sameby (County Administration in Norrbotten and Jämtland). Short, dotted line indicates the maximum permitted herd size in Mittådalen and Idre (Svensk rennäring 1999). - (Sameby: Saami village)

availability of grazing. Statistics are unreliable, owing to deficiencies in reports submitted to the Board of Agriculture. In 1993/94, the reports stated that 98,300 reindeer were slaughtered, of which $39 \%$ were calves and $61 \%$ were adults. A comparison with the report from 1998/99 shows that slaughtering had been halved during the intervening period; 49,092 animals were slaughtered, of which $60 \%$ were calves and $40 \%$ were adults. The slaughter of calves had thus increased by $21 \%$ (Svensk rennäring, 1999).

\subsection{Herd size over time}

The genus Rangifer, whether wild, tame or allowed to run wild, is present within large parts of the northern hemisphere's boreal and arctic regions, where it is exposed to different influences imposed either by nature or by man. Diseases and lack of forage, together with predation, have long been regarded as important factors that limit the size of animal populations (Fowler 1987, Andersson 1982).

However, in the arctic world the islands of ten lack predators and the reindeer herds are regulated by access to grazing, weather fluctuations and, to some extent, hunting (Vibe 1967, 1982, White et al. 1981). In mainland areas, the populations are additionally exposed to slaughter 


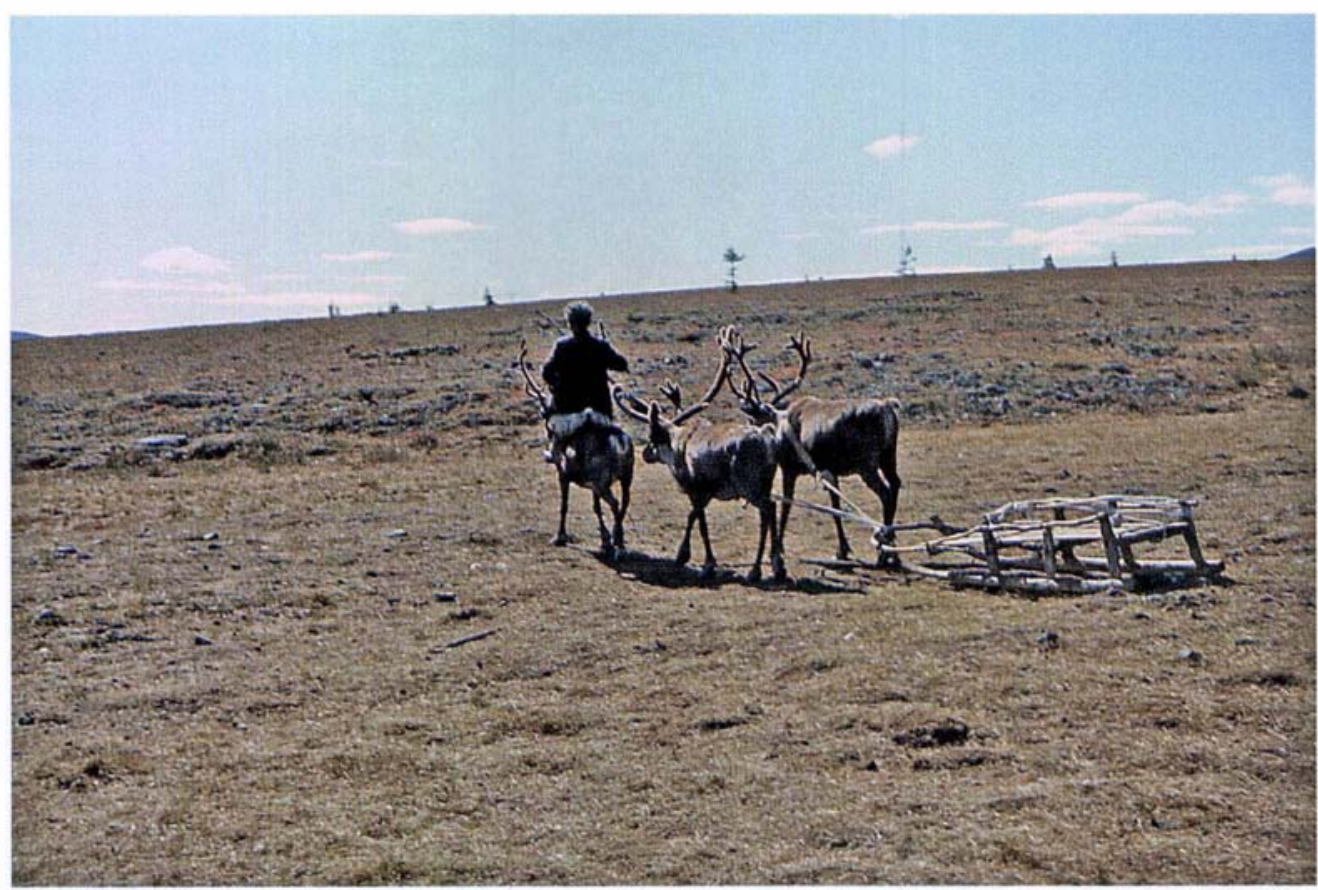

Fig. XVIII. In Sakha (Yakutia), the reindeer is still used for riding and draught purposes more or less throughout the year. Photo: O. Eriksson september 1973

or hunting of varying intensity (Syroechkovskii 1984, Bergerud 1980, 1983). Reduced grazing land, forestry and forest fires are other influencing factors (Eriksson \& Raunistola, 1990, 1993, Eriksson et al. 1987, O. Eriksson 1979, 1980, 1984a, Klein 1982, Miller 1976, Uggla 1958). In this way, the reindeer populations that are exposed to predation commonly loose $50 \%$ or more of their calves. Abandonment of calves and physiological or medical disorders have a lesser influence on numbers (Eloranta \& Nieminen 1986, Nordkvist 1980, Bergerud 1971). For the entire Swedish reindeer herd, the variation in numbers during the past century or so has been about $25 \%$, around a mean level of about 225,000 reindeer in the winter population. The winter population refers to the number of animals following the annual cull, but before calving (Svensk rennäring 1999).

The variation is cyclic, with peaks about every 25 years. The dips in the 1920s, 1940s, 1960s and 1970s were mainly caused by long winter periods, with snow conditions that hindered migrations without breaking up the herds, and which completely or partly prevented the reindeer from reaching ground grazing. Examples of such snow conditions are:

- Tjuohki, ice cover after rain on cold open ground (Swedish 'flen').

- Skarta, thawed, packed snow cover directly on the ground, encapsulating the ground vegetation.

- Tsaevvi, an inner layer of snow inside the main snow cover at temperatures around $0{ }^{\circ} \mathrm{C}$, that prevents the reindeer from smelling the presence of ground vegetation.
- Tjaerga, wind crust, hard wind-packed snow.

Tsuongo, thaw crust, a thick layer of thawed and later frozen packed snow.

- Snow depths of more than $80 \mathrm{~cm}$.

(The 1909 Reindeer Grazing Commission 1912, Ruong 1964,

N. Skum, pers. comm., O. Eriksson 1976)

As can be seen from Figure IA, the number of reindeer has fluctuated widely within 'our' research Saami villages during the 20th century. The explanations are probably the same as those that governed the variations in the national population. The neighbouring villages Lainiovuoma and Saarivuoma had similar reindeer population peaks around 1935 and 1955, after which the number of reindeer in Saarivuoma decreased to about 6,000 during the 1970s, before increasing again to about 12,000 during the 1980s. Lainiovuoma had a very uniform number of reindeer during the period 1960-1990, about 10,000 head. During the 1990s, both villages suffered severe reindeer losses on account of difficult winter-grazing conditions and poor calving results.

Sörkaitum and Mellanbyn had the best figures during the 20th century, with $8-10,000$ reindeer around 1930, 1955 and 1990, but with large decreases in-between and towards the end of the 20th century. Sörkaitum, in particular, suffered severe losses, for the same reasons as those that affected Lainovuoma and Saarivuoma before the turn of the century (Svensk rennäring 1999).

The Mittådalen Saami village had a uniform number of reindeer up to the middle of the 1970s, around 3,000 head, after which the herd increased rapidly, and during 


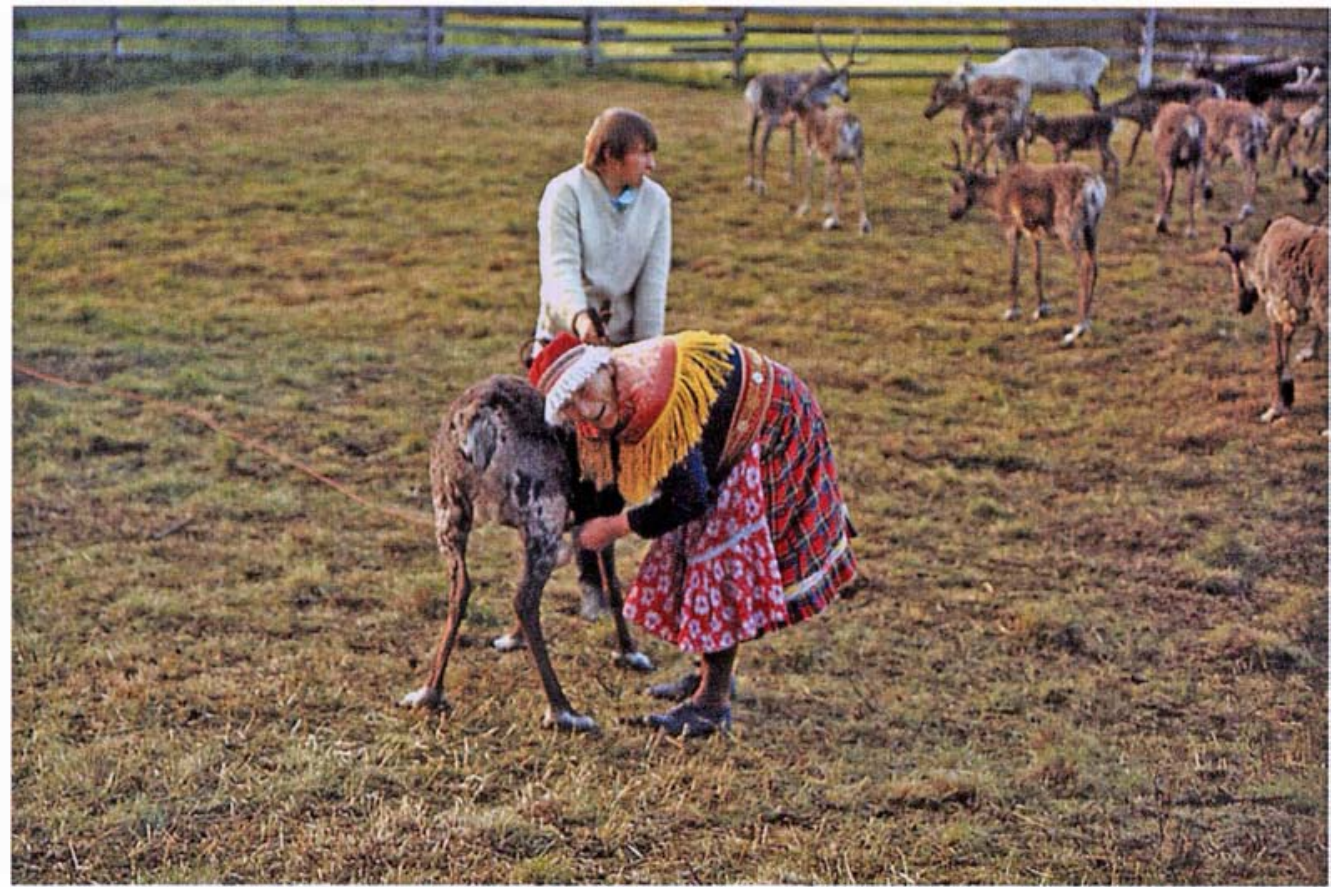

Fig. XIX. Female reindeer (vajor) were milked to a limited extent until the 1980s. At an earlier stage, reindeer milk was important in the diet and in the domestic economy. Reindeer cheese is nutritious and can be stored, and is therefore an attractive commercial product. According to Ruong (1982), the protein content is $10.9 \%$, the fat content $17.1 \%$ and the milk-sugar content $3.8 \%$. The photograph was taken at Vivungi, in Vittangi forest Saami community, by O. Eriksson in July 1968.

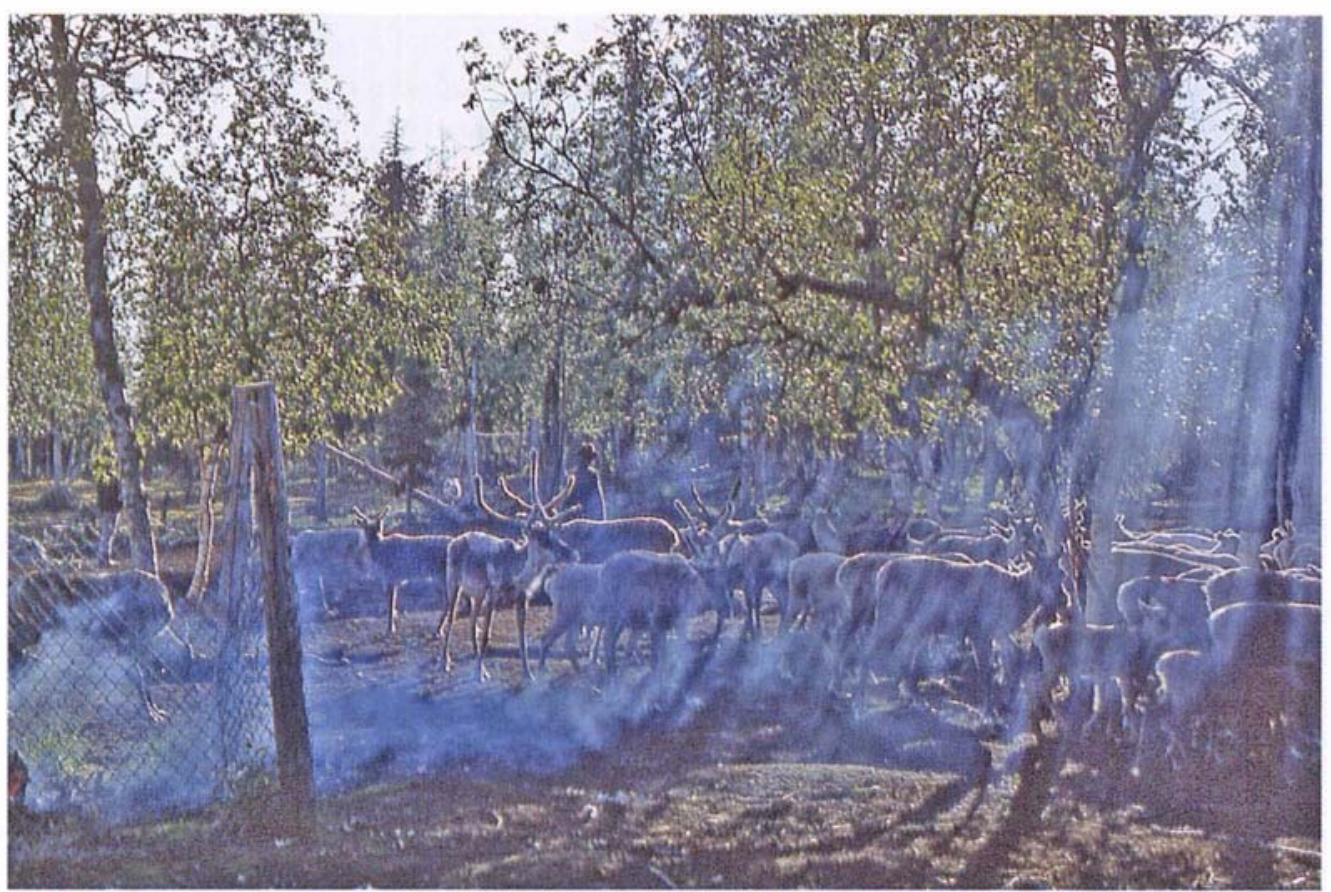

Fig. XX. When the reindeer are gathered in summer in enclosures for marking and occasional milking, the irritation caused by biting insects is reduced with the help of smudge fires (Saamish suovva). Viikusjärvi, Vittangi forest Saami community. Photo: O. Eriksson, July 1969. 
the 1980s and mid-1990s numbered around 9,000 animals. Subsequently, a decision by the village council led to a considerable reduction.

Idre new Saami village was reorganized in 1984, after a long depression during which only sporadic reindeer counts were made. The new village's reindeer numbers decreased sharply during the 1980s, and during the 1990s the number was relatively even (around 3,000), which corresponds to the maximum number permitted.

\subsection{Reindeer domestication and handling}

The utilisation of the genus Rangifer in a more or less domesticated form is originally associated with the Old World. This includes attempts during the 19th and 20th centuries to introduce reindeer husbandry as an alternative occupation for native peoples in North America and on Greenland (Skjenneberg \& Slagsvold 1968). Marco Polo (1967) mentions a tribe dwelling in the Lake Baikal region during the latter part of the 13th century, which owned reindeer and utilised them as riding animals. Laufer (1917) discovered, in still older Chinese annals, notices referring to reindeer husbandry on the northern boundary of the Chinese empire. From a knowledge of linguistic and literary sources, he dates the beginning of reindeer husbandry to the beginning of the present era, in the Baikal region. This evidence probably refers to the Soyots, huntergatherers on a tributary of the River Yenisey in the Sayan Mountains, who also carried on some reindeer husbandry. Their herds were small, and rarely comprised more than 50 animals, which, however, were large and readily tamed. They were used as beasts of burden, for riding, as decoys and for milking, but rarely kept for slaughter (Wiklund 1919). Vainshtein (1980) is of the opinion that the reindeer has been domesticated in Siberia since at least the last millennium B.C.

In the course of time, a number of peoples within the distribution area of the reindeer in Eurasia have developed various forms of domestication, which have led to various degrees of tameness. If meat production is the sole aim, then naturally a lower degree of tameness is required (but docility at the level of the herd), compared with what is required of reindeer used as riding or draught animals. Vainshtein (1980) illustrated, on the basis of significant cultural traits, areas of utilisation among reindeer-herding peoples (here reproduced in a somewhat simplified form):

Saami type: Pack-carrying; Draught; Milking; Herding with the help of dogs; Hunting with the help of decoy reindeer.

Samoyed type:(W. Siberia) Draught; Hunting with the help of decoy reindeer; Herding with the help of dogs; No milking.
Tungus type: (East of Lake Baikal) Pack-carrying; Draught; Riding without stirrups; Milking; Herding with the help of dogs.

Koryak type: (North-Eastern type) Draught; Hunting with the help of decoy reindeer; Herding without dogs.

Sayan type: (West of Lake Baikal) Pack-carrying; Riding with saddle and stirrups; Milking; No hunting with the help of decoys; No herding with dogs.

Riding in the strict sense did not occur among the Saami, but children and persons enfeebled by age could occasionally be carried on reindeer-back during a migration (Ruong 1982). Milking has been practised sporadically by most reindeer-herding peoples (op. cit.). The systematic use of milk occurred only within the Saami-, Tungus- and Sayan-type of reindeer husbandry. For example in the Vittangi Saami village, parish of Kiruna, reindeer were milked until the 1980s, to maintain the tradition (L. Berggren, pers. comm.). The employment of tame reindeer as decoys in the hunting of wild reindeer is a method used by the three northerly types, Saami, Samoyed and the north-eastern (Koryak) type (Vainshtein 1980).

The origin and development of methods of reindeer husbandry and equipment follow several paths of development or combinations of such paths. Examples of these are innovation and development within a given population, knowledge transfer between reindeer-herding peoples and the copying of types of equipment, terminology, etc., from neighboring peoples who have domesticated other species of animals. Examples of this are riding, draught- and transport- equipment, such as saddle and stirrups, bridle and pack-saddle from horse-based cultures, and sledges adapted for pulling by reindeer, adopted from peoples who use dogs as draught animals (Wiklund 1919).

The reasons for the adoption of reindeer-herding within peoples originally dependent on hunting and fishing have been the subject of lively discussion during the past century. During the first half of the century, a range of hypotheses was presented by ethnologists and philologists. Lundmark (1982) commented on the shortage of reliable source material for these hypotheses. Since the mid-1950s, research has been placed on a considerably firmer foundation following Tegengren's (1952) and Hultblad's (1968) thorough analysis of the historical source material from Finnish and Swedish Lapland, respectively. Zackrisson (1976) was responsible for the introduction of archaeological source material into the discussion. In recent research into the introduction of reindeer husbandry, the ecological context has been studied by means of palaeoecological methods (Aronsson 1991). According to Fjellheim (2004), the shift in the natural economy of the Saami may have been brought about by environmental factors, originating in climatic changes in the 16th and 17th centuries, which made it advantageous to change from a hunting-based economy to nomadic reindeer husbandry. Ingold (1980), 
Lundmark (1998) and others consider, however, the transition to be a product of changes in human society. Thus the introduction, and subsequent expansion, of reindeer husbandry might be explained by a process of ecological adaptation and economic specialisation. In the inland areas and the mountains, reindeer husbandry, combined with hunting and fishing, was the natural development, while agriculture advanced in the coastal areas of northern Sweden (Aronsson 1995).

The earliest mention of the reindeer as a domestic animal in Scandinavia can be found in the narration of Ottar, from the latter part of the 9th century (Alfred's Orosius). Ottar told of the ownership of decoy reindeer and of a herd of 600 tame reindeer. Some scholars, e.g. Manker (1947) and Ruong (1982), consider that some form of reindeer husbandry already existed during the late Iron Age, whereas others, e.g. Steckzen (1964) and Selinge (1982), would date its origin considerably later. Lundmark (1982) accepts the possibility that small herds of reindeer may have been used for hunting, as decoys and as beasts of burden, even before the introduction of direct domestication during the 17th century. This view appears to be supported by Zackrisson (1984). Elucidation of the distinction between reindeer nomadism and a Saami hunting culture is important to the understanding of reindeer husbandry in earlier times. By the term 'reindeer nomadism' it is to be understood that the herd of tame reindeer is the basis of the economy. This leads to a way of life in which the Saamis follow their herds throughout the year, and live mainly on them. In the hunter society which preceded reindeer nomadism, there were also reindeer, but these had a subsidiary function within an economy based on hunting, fishing and the gathering of food plants (Lundmark 1982). Hunter-fisher peoples have lived in northern Scandinavia for thousands of years - the earliest traces of dwelling sites in the inland areas date from 7000-6000 B.C. (Aronsson 1995, Kuol jok 1998). The Saami identity developed among them from the 6th century A.D., when 'external' competition from other peoples increased (op. cit.).

\section{Saami and reindeer husbandry - some definitions}

The Saami culture exhibits a wide range of variation in time and space. A number of terms has been used to describe these variations. Not all such terms are unequivocal, hence some lack of clarity, and misunderstanding, have arisen (cf. Lundmark 1985, Aronsson 1991 and Sköld 1992). To characterise their adaptation to the environment, the following terms are used here:

Forest Saamis: (earlier called Spruce Lapps, ForestLapps). These make their living in the taiga throughout the year (Ruong 1982, Aronsson 1995).

Mountain Saamis: (Mountain Lapps). These live above the coniferous forest limit for much of the year. Their migrations between the summer and winter grazing areas are of ten of considerable length (op. cit.).

Northern Saamis - Southern Saamis: These names are principally based on linguistic differences. A long history of contact has also given rise to some cultural variation, which should not, however, be regarded as a sharply defined cultural boundary (op.cit.). The valley of the Lule river may be seen as an approximate boundary, since Saamis living north of it principally were in contact with a settled population who spoke a Finnish dialect (Mienkielin), while those who lived south of it had their external contacts with Swedish speakers (Marainen 1984).

Semi-nomadism: A special and original form of small-scale reindeer husbandry, combined with hunting, fishing and some wage labour, which has been common throughout northern Eurasia. Migrations are usually of limited extent (Ruong 1982, Aronsson 1991, 1995).

Reindeer nomadism: Herds of tame reindeer are the basis of the economy. Migrations between summer and winter grazing areas are often of considerable length (Lundmark 1982, Rheen 1983).

Intensive reindeer husbandry: Indicates a multi-facetted utilisation of the reindeer and reindeer products: reindeer are used as draught- and pack-animals, for milking, as a source of meat and hides, and for selective slaughter (Paine 1972).

Extensive reindeer husbandry: This implies a tendency towards the sale of animals for slaughter (op. cit.).

In general, it may be said that intensive reindeer husbandry is aimed at a natural economy, whereas extensive reindeer husbandry leads to a monetary economy. The meaning of the terms 'intensive' and 'extensive' fluctuates somewhat, however, depending on whether they are associated with the herding of reindeer in contrast to reindeer husbandry as a business. When associated with herding, they imply a varying degree of tameness, and when associated with business, they tend to indicate different degrees of utilisation. Among both forest Saamis and mountain Saamis thereexist both reindeernomads and semi-nomads, with a varying length of migration, as well as hunters, fishers and other occupational groups. They can also be northern Saamis or southern Saamis. Within the Saami village, reindeer husbandry can be intensive in some respects and in others, extensive, e.g. as regards migration, herding and provision of fodder.

\section{Husbandry of forest reindeer}

The entire annual cycle is passed in the taiga. During the snow-free period, areas which provide fresh forage adjacent to wetlands are grazed. When there is a snow cover, areas of coniferous forest which provide ground- and arboreal lichens as well low brush and a few graminoids, are grazed. Originally, the reindeer herds were small, but were kept together. Herds were moved over fairly short distances between milking areas with good grazing, and with some means of reducing disturbances caused by biting insects, 
e.g. smudge fires, and-for preference-good fishing. In autumn and winter, herd movements were determined by the availability of opportunities for hunting, and access to grazing. Within a family, the division of labour was such that the women were responsible from an early stage for dealing with the animals, while the men were occupied with hunting and rapping. As the number of reindeer increased, however, the men became increasingly involved with the reindeer (Ruong 1944, Marklund 2004). The transition to the reindeer nomadism of the forest Saamis (with hunting and trapping as more or less important adjuncts) continued throughout the 18 th century. At the turn of the 18/19th centuries, a clear shift was evident (Marklund 2004). Ruong (1944) considers, however, that the forest Saamis at that stage did not strategically choose major change, but that they attempted to maintain balance within the system. As an example, it may be mentioned that a 'big reindeer owner' in the Arvidsjaur Saami village owned 60-80 animals at the end of the 18th century (Marklund 2004).

\section{Mountain reindeer husbandry}

The migration pattern of the reindeer is followed. Between spring and autumn, the mountain grazings are utilised, from the tree limit (Saamish: 'orda') upwards to the mountain heaths. The winter is normally passed in the lichen-bearing coniferous forests.

As early as the 16th century, the Saamis were divided into 'spruce Lapps', i.e. forest Saamis, and 'mountain Lapps', who mainly lived in the mountain areas. The latter lived on reindeer products to a greater extent than the former. Hunting and fishing were of lesser importance to them (Rheen 1983). Developments during the 17th century, towards full-blown nomadism, resulted in their migration areas having a narrowly elongated shape, approximately orientated in an east-west direction, and adapted to the migration pattern of the reindeer and to the course of the rivers which formed the boundaries of the areas (Beach 1981, Ruong 1982). Their herds also came to be considerably larger than those of the forest Saamis. Rheen (1983), then priest at Jokkmokk, wrote regarding tame reindeer in the 17 th century that 'Tame reindeer are they that increase the Lapps' reindeer, of which many Lapps own 100, indeed 1,000 , and some more ... the Lapps own many more female than male animals, so that the Lapp who owns 100 females has no more than 20 or 30 males, since it is through the females that their herds increase ...'.

\section{Good grazing-poor grazing}

This classification can include many usable forage plants within a given seasonal grazing area. It can also cover accessibility, which usually is determined by snow conditions - snow depth, density, hardness, etc.

\section{The Saamis and the authorities}

One of the contacts with the outside world, which in time came to be burdensome to the Saamis, and strongly influenced their way of life, was their tax liability, earlier mentioned by Ottar and by the authors of the Icelandic sagas (Ruong 1982). The boundaries between nation-states were not as yet delimited, hence the Saamis, at worst, could face demands from tax collectors - doubling as traders - from the chieftainly domains in northern Norway, from Finnish and Russian areas, and from Sweden. Novgorod was long the most prominent power in upper Norrland, and based its tax-collection and its trading system on a series of intermediaries. Local élites acted as an extension of the authority of Novgorod in the area around the White Sea and the Gulfs of Bothnia and Finland during the 13th century (Lundmark 1998). Furs, prized throughout Europe, hides and hide-based products were both the most important trade items and the basis for taxation from an early stage.

The source material concerning the earliest Swedish presence in northernmost Fennoscandia is meagre, and is based on hunting and trade expeditions, which long transgressed present-day national boundaries. In essence, the land was considered to be 'waste' before the 14th century, but was sporadically crossed by Saamis, who had been exposed to military incursions by peoples 'from the east'. After peace with Novgorod was declared at Nöteborg in 1323, the Swedish Crown aimed at securing its suzerainty over what had now become Swedish-Finnish territory - and naturally to benefit from whatever taxes that could be demanded. The Novgorod system of tax collection having been seen to be inefficient, it was decided to establish a new system. This was admittedly based on a body of tax collectors - 'birkarls' - who earlier had served Novgorod, but who now derived their authority from, and were directly responsible to, the Swedish Crown. The origin and designation of these 'birkarls' has long been the subject of lively debate by many scholars. One theory was that they originated in Pirkala parish near Tampere in Finland. An attempt was even made to equate the word 'birkarl' with the name of the settlement Birka, and with animals-beaver, 'bjur' - which provided a highly regarded fur. The 'birkarls' are first mentioned in a document dated 1328 , in which it is stipulated that their travel and trading activities should not be disturbed, and neither should the hunting activities of the Saamis. The 'birkarls' are described in the document as a group of wealthy farmers residing in the coastal areas of the parishes of Pite, Lule, Torne and Kalix, who possessed the privilege of trading with the Saamis and of taxing them, subject to the payment of fees to the Crown. This system appears to have operated with little change up to the middle of the 16th century. Its main beneficiaries were undoubtedly the 'birkarls', since the annual fee to the Crown was only eight marten pelts and 1280 squirrel pelts. Before 1528 , the 'birkarls' paid only half that fee for their privileges. 
King Gustavus Vasa laboured untiringly to increase the revenues of the Crown. Among such efforts were successive increases in tax liability. Even the Saamis were liable to pay tax by families. In 1553 , individual tax assessments were introduced in the province of Västerbotten, i.e. over more or less the entire extent of the current provinces of Norrbotten and Västerbotten. In Pite-, Lule- and Torne Lappmarks, 301 'tax Lapps', i.e. Saami families, were registered for taxation, at the same time as they were taxed at values which in total far exceeded the fees previously paid to the Crown by the 'birkarls'.

The new realisation of the tax-paying capacity of the Saami areas led to major changes. The 'birkarls' lost their right of taxation, but on payment of a fee, were confirmed in their old right to trade with the Saamis. After some time, one 'birkarl' in each Saami area became a tax-collector for the Crown, and was given detailed instructions to extract, with the help of the taxation rolls, the tax due from 'his' tax-liable Saamis, and to deliver an account and tax revenues to the Treasury in Stockholm.

The tax levied on each family was, as a rule, one or two bundles of furs (squirrel pelts; one bundle equals 80 pelts), or one or two marten pelts, and possibly, a quantity of dried fish. In other words, not an especially heavy burden. The steady increase in the number of Saamis liable for tax indicates a degree of prosperity towards the beginning of the 17 th century. Trade with the Crown and with the 'birkarls' provided an influx of goods, money and precious metals (mainly silver). The transactions took place in connection with winter fairs, which were held at the winterdwelling-places at a time of year when, owing to the weather, hunting and trapping were less profitable. The addition of purchased flour and butter introduced agricultural produce to the diet, and tided over a period of dietary insufficiency, which could have fatal consequences.

Trapping, hunting and the initially small reindeer herds had earlier sufficed for the needs of the sparse population. Increased population size, increased trade and the introduction of goods produced outside the Saami areas, led to difficulties when the supply of game and fish began to decrease as a result of increased pressure on the natural resource base, and possibly also in consequence of climatic deterioration.

The fiscal demands of the Crown could be met during the 16th century, so long as they primarily consisted of furs, which in any case were little used in Saami society, where reindeer hides were more important. At the beginning of the 17th century, the Crown abruptly changed its taxation policy. The reason for this was that Sweden was at war with Poland, and that the campaign of 1601 had been a failure as a result of the lack of food supplies. In March 1602, King Charles IX decreed a new tax on the Saamis, which was to be paid in reindeer and in increased quotas of dried fish. After some transitional difficulties, a new tax ordinance came into force from 1607. Every
Saami household was to contribute two reindeer and eight 'lispund' of dried fish by way of tax (1 'lispund' equals 6.8 $\mathrm{kg}$; 8 'lispund' corresponded to ca. $150 \mathrm{~kg}$ live weight). In addition, the Crown was to have a tithe of reindeer calves and a tithe of dried fish. Such a tax demand, framed in terms of foodstuffs, was a serious blow to the Saami economy. The reindeer demanded by the Crown as tax were initially retained in the Saami areas, with the help of hired Saamis as herders. In 1610, the Crown's reindeer, which were carefully recorded by the tax-collectors, amounted to ca. 1,000 in Lule Lappmark alone. They were successively slaughtered and the meat was sent to Stockholm. King Charles IX showed a close interest in reindeer husbandry. Large herds of Crown reindeer in the Saami areas were one of his visions for increasing the exploitation of the resources of the Saami territory. Attempts to farm reindeer in the province of Medelpad were a signal failure.

The new tax led to a crisis in the economy, since the Saami population had already outgrown the limits of the trapper society. The wretched condition of the Saamis is documented in reports from the tax-collectors and in petitions to the King from, among others, priests active in the Saami territories. The tax revenues decreased successively, and in 1620 it was necessary to halve the tax, for lack of a sufficient tax base. After a few years it was further reduced, and lay at the level of two 'lispund' of dried fish or one thaler or two pairs of shoes of tanned hide.

The supply crisis led quite rapidly to innovations among the forest Saamis. When the old economy, based on hunting and trapping, no longer sufficed, there was a gradual transition to a strategy based on a greater year-round utilisation of the reindeer. This was undoubtedly reinforced by the other products that nature could provide, such as fish, game and vegetables. It is here possible to speak of a gradual transition from a trapper society to a semi-nomadic way of life. Forms of contact between Saami society and the outside world, other than the purely fiscal, may also have contributed to steering development away from a hunterfisher culture, via various intermediate forms, to reindeer nomadism and present-day reindeer husbandry.

From 1500 onwards there is evidence for the division of the Saami territories into very large community holdings, sijdas, which were more or less circular in shape, and adapted to the trapper society's utilisation of its resources. The holding comprised the fishing-waters, hunting-grounds, etc., required for supplying the community's needs throughout the year. This division had probably arisen far earlier than the 16th century. Within the holding, which could comprise about one hundred members, smaller areas were allotted to individual families. Each family possessed, as a rule, several tracts of land, between which it migrated as necessitated by the seasonal food supply.

Within the sijda there was originally a single, common dwelling site, dalvvesijd, to which the families returned in autumn when communal hunts for wild reindeer and 
other labour-intensive activities took place, and which were the prerequisite for winter survival. Mid-winter was a quieter period, which provided opportunities for social activity. Matters of common interest were taken up by the sijda council, which was made up of the heads of families and functioned as a legal body. Judgements were given, disputes were ventilated, land was re-allocated in accordance with changes in the needs of families or because new families had been formed. The council also dealt with external contacts, with other sijdas, with traders and tax officials, who before the 16th century could originate from several sources. The natural boundaries of the sijdas were well known to all concerned.

The changed tax policies of the Crown also affected the sijda system. In 1602, King Charles IX decided that the Saamis should attend fairs at fixed sites every winter. There they would pay tax, and when churches had been built, would also attend services. The administration of justice was also associated with the fairs. Traders were prohibited from doing business at the old dalvvesijdas. In 1611, King Charles IX died, and with him died the interest of the Swedish Crown in the intensive exploitation of the Saamis for tax purposes.

\section{The silver-mining era and the Saamis}

In 1634, argentiferous ore was discovered on Nasafjäll, which lies near the Norwegian border in the present-day Arjeplog municipality. In Stockholm, where knowledge of the riches seized by the Spaniards in the New World, including silver, was widespread, it was supposed that Nasafjäll was Sweden's own new Eldorado, which must be exploited as quickly as possible. As has already been noted, Sweden's many wars had strained the Crown's finances. The collector of Saami tax in the Pite district was made responsible for ensuring, with the help of hired Saamis and their pack- and draught-reindeer, that ore was transported from the mine to the smelting-works at Silbojokk at lake Sädvajaure, and thence to the coast at Piteå, a roadless distance of ca. $400 \mathrm{~km}$. In compensation for this, a tax reduction and other appropriate benefits were to be offered. However, it proved difficult to recruit a sufficient number of reindeer drivers, which led to an unsuccessful attempt to solve the transport problem by coercion. As a last resort, the Saamis assigned to transport duties reacted by fleeing from Pite Lappmark over the Norwegian border, or down to the coast of the Gulf of Bothnia. The mine ran at a loss for a number of years, until Danish troops invaded from the Norwegian side of the border and burnt down the mine buildings, which were never afterwards rebuilt.

The Crown had discovered a new source of silver in the mountain Kedkevare, north-west of Kvikkjokk. Mining began during the 17th century, and in this case also, the Saamis were to be responsible for transporting the ore. The governor of Västerbotten, Johan Grahn, who himself was of Saami extraction (and incidentally the only Saami ever ennobled), strove hard with the help of his contacts in the government to improve the situation of the reindeer drivers. At the start, his efforts were fruitless. The Saamis fled even from Lule Lappmark, especially after a new ore body was discoved at Alkavare, near Kedkevare, and an increased need for transport was therefore to be expected. The number of Saamis registered as resident in Lule Lappmark declined during the mid-17th century, from almost 200 to 65 .

At the beginning of the 18th century, the mines at Kedkevare and Alkavare were almost worked out. The Saamis had returned, and the population of Lule Lappmark was once more at its 1650 level. Toease pressure on the Saamis from mines and smelting-works with a large demand for transportation, Johan Grahn suggested that the Saami territories should be opened to colonisation by pioneers from an agricultural background, and who were familiar with the use of the horse as a draught animal. This was done out of consideration for the Saamis-he did not foresee its consequences.

\section{The colonisation of the Saami territories}

As was mentioned in the Introduction, the utilisation of the Saami territories foragriculture is, in an historical perspective, a very recent event. From the 16th century onwards, the Crown's interest in establishing a settled, agricultural population in the 'waste areas' increased; this was a prerequisite for the assertion of territorial rights over the land, which increased in importance with the discovery of silver deposits in Pite and Lule Lappmark. The inclination among the population in general to colonise the Northlands was, however, limited. It increased when, in 1673, the Crown promulgated the 'Lappmarksplakatet', which provided for benefits coupled to settlement in the Saami territories; tax exemption for 15 years and relief from military service, those which probably were of greatest importance.

Colonisation increased successively, and with it the frequency of disputes between the Saami and the colonisers, principally regarding the right to fisheries. These disputes were of ten ventilated in court, where at the start the Saami side of the argument was successful, since the assessors were usually Saami, who were aware of the problems of obtaining a livelihood. Cases brought by Saami plaintiffs often involved unlawful entry into fisheries. The colonisers made claims concerning damage to hay by passing reindeer herds, the hay having been left unprotected on wooden hay-drying racks, to be brought in later when a snow-cover facilitated transport. The damage consisted in the overturning of hay-drying racks, and trampling and fouling of the hay when the reindeer attempted to reach forage plants, such as Equisetum spp., Menyanthes trifoliata and Potentilla palustris, which were mixed with the hay. 


\section{Regulations concerning the Saami territories}

By the mid-18th century, the conflict of interests had reached such proportions that the Crown, in 1749, promulgated a set of regulations applicable to the Saami territories, which aimed at defining their utilisation. The colonisers were primarily required to carry on cultivation and animal husbandry. They were given limited hunting rights within an approximate $5-\mathrm{km}$ radius from the smallholding. Fishing was permitted within the same area, including waters over which the Saamis had rights. The Saamis themselves were required to confine their hunting, fishing and reindeer husbandry to the areas subject to taxation.

Up to the mid-18th century, the large-scale reindeer nomadism that had begun during the 17 th century, had developed into a profitable occupation, which gave the Saamis trading advatages over the still limited settled population. From the latter part of the 18th century onwards, decisive changes took place; colonists arrived in increasing numbers, and the proportion of Saamis in the population of the inland and mountain areas declined. The importance of reindeer husbandry to the economy also declined in step with the increased importance of other forms of enterprise. The situation of the Saamis now deteriorated markedly, mainly in consequence of the measures taken by the authorities. For example, the Saamis' chances of succeeding in legal disputes with colonisers were sharply curtailed. Within Saami society itself, several negative changes occurred. To begin with, the reindeer herds suffered severe losses. From the mid-18th to the beginning of the 19th century, years of dearth in reindeer husbandry repeatedly occurred. In Jokkmokk parish, for example, two-thirds of the reindeer herds perished in 1756. Even the years 1786, $1796,1813-1816,1830-1837$ and 1843 appear to have been afflicted. As a result, the Saami population of Lule Lappmark decreased by half in the latter part of the 18th century and during the first half of the 19th century.

The crisis in reindeer husbandry was probably caused by a combination of factors, e.g. by a shortage of grazing due to weather conditions, by increased losses of animals to predators, and by disease among the reindeer. There may also have been an imbalance between the number of reindeer and current methods of husbandry, whereby the reindeer herds were concentrated and the hinds were milked on overgrazed pastures, with a consequent risk of disease transmission. That the milking areas and grazings were heavily exploited, is illustrated by the fact that, from the end of the 18th century, disputes between Saamis concerning the areas liable for tax were increasingly decided by the courts.

\section{The 1751 boundary decision affecting Denmark- Norway and Sweden-Finland}

In 1738 , a boundary commission began work on defining a national boundary between Denmark-Norway and Sweden-Finland. The boundary was mainly to follow the watershed along the Scandes. The local populations, including the Saamis, were given an opportunity of presenting their views on the proposed alignment of the boundary. In Finnmark, in the farthest north, Sweden withdrew its claims to the parishes of Kautokeino and Karasjokk, but received in compensation the parishes of Idre and Särna in the province of Dalarna, which formerly had belonged to Denmark (Ruong 1982).

The border divided the Saami lands into a Danish and a Swedish sphere of interest. In the Saami context, there was initially no real border, and it was therefore of little importance. The mountain range (the Scandes) was already divided into different sijdas for late spring grazing and early autumn grazing. The sijda areas extended across the Scandes, defined by the alignment of the Swedish valley systems (Marainen 1984).

Two codicils were appended to the boundary treaty, which was signed in Strömstad in 1751 by representatives of both kingdoms. In one codicil (Lapp-codicil of 1751), the rights and obligations of the migratory Saamis in both kingdoms were defined. In spring and autumn, the Saamis, in accordance with ancient custom, were permitted to move with their reindeer from one kingdom to the other. Without regard to the border, they were permitted to utilise both land and shore for the sojourn of both people and animals. They were to be received amicably, and protected even if a state of war existed. They were to pay tax only in the kingdom in which they were registered as resident.

The codicils, with their humane spirit, are remarkable for their time and have been called the Saami Magna Charta. They constitute a kind of charter of rights for the Saamis in Sweden and Norway, which, however, has partly been invalidated by subsequent historical events.

\section{The boundary of the Saami territories}

After the mid-18th century, the Swedish Crown came to regard all land that was not subject to Saami taxation, as belonging to the state. The intention was to promote the establishment of colonists, even where the natural circumstances were not directly favourable. One means was to prevent the coastal farmers, who from mediaeval times had hunted and fished in the inland areas without much regard for the sijda, from competing with the Saamis and colonists. In 1751, a boundary was established, the 'Boundary of Saami Territories' which corresponded, by and large, with the boundary which at present separates the provinces of Norrbotten and Västerbotten from Lapland. The land west of this boundary (i.e. Lapland) was to be utilised only by colonists and Saamis. 


\section{Cultivation limit}

During the 19th century, the pace of colonisation greatly increased, which was to the disadvantage of the Saamis, who lost reindeer pasture in the form of wetland- and meadow-plants, which were mowed by the colonists as winter fodder. Access to fisheries was essential to the colonists, especially during the establishment phase, and had always been essential to the Saamis. Intrusions into fishing waters were consequently a severe blow.

In 1873, the 'limit of cultivation' was set out. This was intended to separate cultivable land from the montane areas in the provinces of Norrbotten and Västerbotten. West of this boundary, no colonisation was to take place, and the Saamis were to have sole rights throughout the year. East of the boundary, they were permitted to keep their reindeer between October and April. The boundary never gave the intended protection to the Saamis. Numerous colonists already existed within the limits of the area, and permission continued to be granted for new settlements. When the value of the natural resources in the mountain areas (minerals, water-power and forest) became apparent, large-scale exploitation began, which was in many respects to the detriment of Saami interests.

\subsection{Reindeer grazing and availability of grazing, from the time of Olaus Magnus}

\section{Reports from pioneers in Lapland}

Early travellers or residents (usually clergy) in the reindeergrazing areas have left posterity few accounts of grazing sites and of the availability of grazing.

The earliest, scanty, information about reindeer grazing during the period of snow cover may be that given by Olaus Magnus (1555). 'The food of this animal (i.e. the reindeer), consists of the white lichens on the hills, especially in winter.'

Olaus Graan served for about 30 years as a priest in the Piteå town and rural parishes, and was well informed about conditions in the Lappish areas. In his 'Relation' (1672), he gave an account of the reindeer's habit of straying widely during the autumn in search of the most attractive fungi. The difficulty of keeping theherds together at that time, and of protecting them against predators, was mentioned.

In 1673, Johannes Schefferus published his work ' $L a p$ ponia', compiled on the orders of the Chancellor, Magnus Gabriel de la Gardie. This was intended to describe both natural conditions in Lapland, and the inhabitants' way of life, and was to focus on the value of the region to society. On the orders of the Chancellor, information was provided by clergy resident in Lapland, and by university students of Saami origin.
Information concerning reindeer forage plants was given by, among others, Samuel Rheen (1671), who for many years was a priest in the parish of Jokkmokk: 'towards autumn, when the ground is snow-covered, the reindeer mainly seek the white moss (i.e. Cladina spp.), which is found both on the mountains and in the forest areas. The reindeer dig for this with their forefeet, by throwing aside the snow and consuming the little they can find beneath it.'

N. Lundius from Pite Lappmark, a student in Uppsala (son of the first priest of Saamibirth, Andreas Petri Lundius, from 1640 minister in Arvidsjaur), related that 'During the period of snow, the reindeer subsist on a particular kind of white moss (i.e. Cladina spp.), which grows in large quantities both on the mountains and in the forests throughout Lapland.' In the work 'Descriptio Lapponiae' (1675), he relates that 'in Umeå Lappmark, the Mountain Lapps travel to the fair on Twelfth Night (Epiphany). When they pass through the (tax)lands of the Spruce Lapps, they ask leave to pursue wild reindeer. Many a Spruce Lapp accomodates up to ten Mountain Lapps, who may stay with their reindeer until Lady Day (Annunciation Day), as there is more winter grazing on the lands of the Spruce Lapps than on their own. The reindeer do not graze on the moss in summer, but on green plants that we call 'misar grass', which grow in water; the root is thick, and above it grow three leaves, which branch off one from another (this probably refers to Menyanthes trifoliata). In summer, both reindeer and Lapps willingly eat Angelica archangelica, which grows beside rapids.' (op. cit.)

Also P.M. Martinière, a French physician, who travelled in Lapland in the mid-17th century, gives an account (Schefferus 1673) of the grazing by reindeer of lichens, ' ... which everywhere are found in vast quantities'.

Olof Rudbeck the Younger was the first to undertake a true research expedition to the northernmost parts of the kingdom. In the summer of 1695 , he travelled as far as lake Torneträsk. In his journal (Rudbeck 1695), he gives some information about the choice of forage plants by reindeer at different seasons, and about their behaviour: 'where food is concerned, they eat not only 'moss', i.e. lichens, but also the leaves of trees and shrubs that grow in the mountains, and diverse herbs and grass, as well as various kinds of fungus, especially Lactarius species. It is remarkable that, notwithstanding the abundance of green forage, they are not as fat in summer as they can be in winter, when they graze on the white moss as long as the snow-depth and absence of an ice-crust permit. But when they are unable to reach the ground-forage, they turn their attention to the grey and black moss that hangs like a beard from tree-branches, and which is called lichen. If reindeer come upon human urine, they lick it up with a good appetite. When reindeer calves wish to suckle, or become separated from their mothers, they call to them with a sound that resembles that made by tame swine. Their hooves are 
of great importance to the ability of reindeer to move in the terrain without losing their foothold. If a reindeer is startled, or otherwise moves of its own volition, it moves by preference against the wind.' (op.cit.)

\section{Linnaeus' travels in Dalarna and Lappland}

In the summer of 1734 , Linnaeus undertook his expedition to Dalarna. His travel report (Iter Dalecarlicum) was not published in Swedish until 1889, and an annotated edition appeared in 1953.

In western Dalarna he encountered lichen-covered areas, both in the coniferous forest and on the mountains. Many of the observations concerning the utilisation of lichens are familiar from Flora Lapponica (1737).

As regards the region, the reindeer forage plants and their use, he recounts: 'In the area around Särna, the only cereal sown is Hordeum vulgare (barley), which often is damaged by frost. The mainstay of life here is principally hunting, fishing and cattle-herding. No state taxes are paid here. The Lapps, who carry on reindeer husbandry, would be more profitable to the state in this parish'.

The farmers must each year collect large quantities of reindeer lichen as winter fodder for the cattle. Every husbandman collects 100-200 loads of reindeer lichen with the help of an iron rake, usually in rainy weather. He takes home loads of lichen in winter, and feeds them to the cattle instead of hay. This keeps them alive, but does not fatten them. The regeneration of the lichens takes 20 years. Where, however, the reindeer has fed on good lichen areas, their regeneration takes only one year. The mountains are the Lapps' summer dwelling, and the forest their winter dwelling. Both, in other words, are utilised. By producing reindeer products, the Lapp would greatly benefit the province. The settlers in Lapland and the Lapps could very well co-exist. In summer, the reindeer do not harm the meadows, and in winter they need no hay. Any competition need only affect hunting and fishing ... It was remarkable to see here that the top of the large, white reindeer lichen was so dry, that one needed only touch it with the fingers, for it to fall into dust, but internally it was not only soft and juicy, but also tough and moist ... One had expected to see more new and unusual species here than in the Lappish mountains, since the area lies so far to the southward, but one was sadly deceived. Barely one-tenth of the species found in Lapland were found here, even though the mountains were white with lichens, such as never were seen in Lapland. The mountains here were as dry as those in Lapland were moist. Shed antlers of wild reindeer were visible on the fields.' In Flora Lapponica (1737), Linnaeus gives information about the reindeer lichens and their importance both to the Saami, and to the settlers.

This is a selection of his information concerning the reindeer's forage plants: a. This lichen is the most important of the plants, that are found in Lapland.

b. Within the plant kingdom, there is no other species that appears in such masses, especially in the forest areas, where the sterile, sandy and gravelly heaths are covered with sparse pine forest. In such areas one can pass through areas $20-30 \mathrm{~km}$ long, where the ground is white as snow and covered only by this lichen.

c. After the ravages of forest fire, the ground may lie quite dry and bare, but where all other vegetation refuses to return, the reindeer lichens thrive abundantly, and after six or more years attain their normal size.

d. ... the reindeer exist during the summer mainly on grass. Then they abandon for preference the warm, forested valleys and climb to the windy mountains, covered by perpetual snow, where they pass the warm midday hours on the snowy mountains. ...

To be able to watch their animals, their owners too, the Lapps, pass the summer on the mountains. At the beginning of autumn, both Lapps and reindeer, the former by the severe cold, the latter by the lack of forage, are compelled to leave this abode of cold ...

e. Even the settlers (whose way of life much resembles that of our farmers) comprehend the benefits of using this lichen. During rainy weather they scrape off with a manytoothed rake this plant, which clings together and is readily loosened from the ground. They gather it into heaps and use it during the winter, after it has been moistened with a little water, as an excellent fodder for their cattle.

f. The reindeer lichen is exceedingly common in almost all Lapland's forested areas, but less abundant in the mountains. The mountains in Dalarna, by contrast, are almost completely covered by this lichen, Lichen rangiferinus (=Cladina rangiferina), Lichen niveus (=Cetraria nivalis), Empetrum and Betula nana, the round-leaved birch.

... On the heaths in Älvdalen there are reindeer lichens, which in moist weather are collected as winter fodder for the cattle.

... The great quantities of Calluna vulgaris (ling) found here, appear to be capable of collection and of feeding to the stock as fodder, as also is horse-dung, which in winter is used as fodder.

... South of Särna, we entered a dense forest, which on the ground was snow-white with lichen, but the branches of the trees were quite black and soft by reason of a black, beardlike lichen, which hung down from their lower parts.

...From Höstnadden and Långfjället, the distant Västerdalsfjällen were visible in the east. Farther to the west lay a large group of mountains, above which the twin peaks of Sulufjället on the Norwegian side appeared. From (Storvättes-) Hågna many mountains were visible to the north and northwest, of which Swucku was the foremost. The whole of this area was largely white, covered by reindeer lichens, but the higher is the mountain, the less (sparser, 
lower) also is the white lichen.

Judging by the accounts of journeys and scientific publications, interestin the quantitative aspects of reindeer forage plants was limited during most of the 19th century. With some exceptions, the observations made were fairly fragmentary. Exceptions were those made by e.g. Wahlenberg (1804) and Hult (1881). It may be claimed, with some justification, that Hult was the first to attempt to quantify the plants that provide food for reindeer.

At the urging of the mining minister Baron S.G. Hermelin, during the summer of 1802 Göran Wahlenberg undertook a mainly botanical expedition in Kemi Lappmark, within the parishes of Utsjoki, Enare and Sodankylä. At that time, these parishes were part of the province of Västerbotten, and were occupied by the sijdas which subsequently invaded Karesuando and Jukkasjärvi. His report (Wahlenberg 1804) also contained information of a geographical and economic nature.

He found Utsjoki parish to consist of a very broken mountainous area. 'The hilltops extend just above the birch forest limit, and are covered with reindeer lichen to the summit. Especially at Mandu jaure in the Uts joki valley system, the hillsides are entirely covered with reindeer lichens, so that they appear quite white at a distance through the sparse birch forest. Utsjoki parish is one of the best lichen areas in the north; these extend parallel with the eastern side of the Scandes, and constitute the regio subalpina Lapponiae of botanical nomenclature. Utsjoki has for this reason always been one of the Lapp congregations richest in reindeer. Almost all true Reindeer Lapps are Swedish citizens. During winter, which is the greater part of the year, they reside within Swedish territory, where they find an abundance of reindeer moss. In this may be found the explanation of the relative liveliness of the winter season in the Lappish areas of Sweden. In Enare and Utsjoki, Wahlenberg found no noteworthy resources of reindeer forage for year-round use, nor was there any noteworthy reindeer husbandry.' (op. cit.)

\section{Zetterstedt's journey in Torne Lappmark}

In the summer of 1881, the professor of zoology at the University ofLund, WilhelmZetterstedt, travelled in Torne Lappmark and adjacent areas of Norway and Finland. His route mainly followed the Torne river and lake Torneträsk, the Norwegian coast in Troms and Finnmark counties and southwards via theAlta and Kautokeino rivers to Palojärvi. Thence he travelled along the Palojoki river to the Muonio and Torne rivers.

In the course of the joumey, excursions were undertaken to collect both scientific information and 'specimens'. Information concerning the economy of the districts through which he passed was noted. His travel report (Zetterstedt 1822) was published the following year.

From what follows, it is evident that observations concerning reindeer forage were somewhat sparing: 'The mountains on either side of the south end of lake Torneträsk were covered with reindeer lichen (Cladina rangiferina) and Stereocaulon paschale. The upper reaches of the Alta river were so shallow, that travel by boat was impossible. The journey therefore continued on foot towards the Kautokeino river, initially through forests of pine and birch. Later, after they had gained height, they traversed a stretch of ca. $40 \mathrm{~km}$ along a fairly level mountain ridge. Open, dry areas were covered by Cetraria nivalis. 'Those areas and hills covered by this plant, show up white even at a long distance. In these mountains, it is incomparably taller and thicker, and the separate lichen stands richer, than in more southerly areas. This lichen too is a sought-after food for the reindeer, and could doubtless be employed as a healthy food for humans.' (op.cit.)

From Kautokeino, it was possible to travel upstream by boat ca. $15 \mathrm{~km}$ along the Kautokeino river, which later became too shallow. The journey to Karesuando continued on foot, to begin with over fairly level terrain covered with Cladina rangiferina, Cetraria islandica, Stereocaulon paschale and Empetrum hermaphroditum.

Subsequently, the land became more boggy. From Karesuando, the return journey began by boat along the border river.

\section{Zetterstedt's journey in Ume Lappmark}

In 1832, Zetterstedt made a round trip in Ume Lappmark, up the Ume river across to the source of the Angerman river and downstream to Åsele, thence via Lycksele to his home in Lund. The primary aim was to collect insects, but also birds. In the course of the journey, a compendious diary was kept, containing both Zetterstedt's own observations and those of a multitude of informants, concerning soils, economy, living conditions, etc., within parts of the parishes of Lycksele Lappmark. In 1833, the travel report was published (Zetterstedt 1833), and as regards reindeer forage, was still less detailed than Zetterstedt (1822). A few observations were made on lichen resources: At Gaskeluokta on the south side of lake Storuman, ca. 40 $\mathrm{km}$ northwest of Stensele, Cetraria islandica occurred sparsely, and epidendric lichens were common, especially on dead trees. Cladina spp., Cladonia spp. and Stereocaulon paschale were abundant, and epidendric lichens were common, especially on dead trees.

The vegetation at lake Vojmsjö resembled that at Storuman. Between lake Torvsjö and Åsele, it was noted that extensive areas of forest had been burnt, although this was illegal - spruce forest to create good grazing, pine forest to burn off the lichens to the detriment of reindeer husbandry, which for reasons of competition was unwelcome in the area. (op. cit.) 


\section{The Lapp bailiffs' yearbooks}

The new taxation law of 1695 stipulated that every 'Lapp village' should have its District Clerk, who, together with the Lapp Bailiff, should allocate and receive the common tax impost on the members of the community, as decided by the state (Beach 1981). During the 18th century, there was a large increase in the number of tax-Lapps and in taxland. The number of disputes concerning questions of land ownership and disposition, which reached the courts, presided over by the Lapp Bailiffs, culminated during the 1750s. They provided the early administration by bailiffs with valuable information about changes in the circumstances of reindeer husbandry, which called for adjustment of existing rules (op. cit.). From the end of the 19th century until the mid-20th century, the archives contain a number of the annual reports submitted by the Lapp bailiffs in Norrbotten and Jämtland to their respective county administrative boards. The reports from Västerbotten are, however, absent from the archives. The reports contain scattered notices about grazing areas and their utilisation. Some examples:

\section{The Lapp bailiffs in Norrbotten}

In 1892, F. Forsström reported that it was possible that there had been more reindeer in Arjeplog in formertimes than at the time of writing, but that a reduced availability of lichen grazing areas had reduced the number of reindeer. It seemed indisputable that the reindeer lichens in Arjeplog had been most evenly distributed and grown most abundantly within the mountain area, in a tract ca. $40 \mathrm{~km}$ wide eastwards from the Swedish-Norwegian border. Spring, summer and autumn grazing, and in former times certainly even winter grazing, must have resulted in the near-exhaustion of the reindeer lichens by grazing and trampling.

In the 1907-1908 report, he told that the Lapps in Jukkasjärvi and Enontekis could, as a rule, over-winter west of Jukkasjärvi church village and $50 \mathrm{~km}$ west of Karesuando during the 1830 s, because the number of reindeer was so small that the lichen grazings in the mountains sufficed. In 1892 , the situation was such that the majority of reindeer were compelled to move to the winter grazings far down in Pajala parish. A long period of spring and autumn grazing in a $40-\mathrm{km}$ broad zone east of the border had, in addition, caused the grazing areas to be so heavily grazed down and trampled, that scarcely a trace of reindeer lichen (Cladina spp.) could be seen (op. cit.).

In the report for 1907-1908, J. Hultin reported that in recent years, the Lapps in Karesuando, Jukkasjärvi and a large proportion of Gällivare parish had begun to move the reindeer herds far too early from the summer grazings down to the autumn lichen grazings, in consequence of which the lichens were both grazed and trampled down. As a result of this abuse, the Lapps would be compelled from year to year to use the lichen grazings in the lowlands ever earlier in autumn (Hultin, J. 1908).

J.O. Holm reported in 1917 that, at the beginning of the 20th century, the Lapps in the villages north of lake Torneträsk-Torne river had begun to exhibit an increasingly marked unwillingness to migrate any great distance southwards for the winter within their winter grazing areas. They remained by preference close to the line Jukkasjärvi-Karesuando.

The consequence was that the areas west of the winter grazings' uppermost parts were too heavily exploited, and became impoverished. In the winter grazings that had remained unused, perhaps for 20 years, the lichen cover had, however, reached a considerable thickness. The main reasons for the unwillingness to migrate farther were said to be business connecions with sedentary villagers, proximity to the town of Kiruna where provisions were purchased, the schooling of the children in the villages of Jukkasjärvi and Lannavaara, and the risk of controversies with farmers in 'the lower country'. The source of the disagreements was the damage that could be caused by the reindeer along their migration route, to unprotected hayracks which often were left by farmers on the hay-mires for later collection and transport over the snow. Farmers might also wish to protectlichen areas close to the villages, since they needed it as fodder both for their own draught reindeer and for domestic livestock during severe winters. To maintain control over the reindeer and to avoid damage, was almost impossible, especially during difficult grazing conditions when the reindeer became scattered over wide areas owing to a lack of forage.

\section{Lapp bailiffs in Jämtland}

In the report for 1899, the Lapp bailiff Axel Frändén reported to the county administration in Jämtland that ten to twelve unfavourable years for reindeer husbandry, with flen, bodni-vihki or both (Eriksson 1976), which had hindered access to reindeer lichens from under the snow, had caused large numbers of reindeer to die of hunger or to become dispersed in all directions while seeking accessible forage. Many of these unsupervised, stray reindeer had fallen victim to predators. Among the Saami, it was claimed that a few wolves could kill as many as 30 reindeer in a night. The number of reindeer, which at the end of 1890 , possibly with some exaggeration, had been estimated at $60-70,000$, and at the beginning of 1896 at 27,000 , was estimated to be 12,000 in 1899 .

Tourists, who appeared in increasing numbers each year, were criticised for having contributed in their own way to the decline of reindeer husbandry, by luring the Lapps away from their nomadic life to an existence as porters and guides.

An important cause of the decline in the reindeer stocks was to be found in the decrease or even disappearance of 
reindeer lichen in the Mountain Lapp villages, with the exception of Tännas and Idre, where there still was good access to lichens. The blame for the decline in the lichen carpets was ascribed to the difficult snow conditions during a series of years, which were said to have affected lichen growth negatively; to trampling during the snow-free period by free-roaming reindeer flocks; and to an abundance of small rodents, which were claimed to destroy 'the root system'. Complaints were also made regarding grazing competition by Saami, who recently had become settlers, and who themselves kept domestic livestock as well as providing grazing during the summer for about 200 of the farmers' horses. The horses were permitted to stray freely on the mountain heaths, with trampling damage as a consequence. In the report for 1900, Frändén reiterated the fear that reindeer husbandry would collapse if, as in the previous decade, the reindeer herds were permitted to roam freely on the mountains and in the submontane areas, trampling and crushing the lichens which, on warm summer days, were thin and fragile. For advice, Frändén wrote to his colleagues, the bailiffs in Norrbotten and Västerbotten. The bailiff in Norrbotten, J. Hultin, considered that the number of reindeer had periodically been too great, so that the annual growth of the lichens had been less than the need for forage. The lichen areas had been grazed down annually, so that they finally resembled those devastated by forest fire.

The Lapp bailiff Fredrik Burman in Västerbotten wrote: 'Even in Västerbotten, the Lapps complain that the reindeer lichens are disappearing from the mountains. It seems improbable that the formation of an ice crust on the ground should be the cause; such things have occurred at all times. The mountain lemming is, however, commoner than formerly, and may be an appreciable factor. Perhaps, too, the Lapps, in their work with the reindeer nowadays, are less afraid of trampling on dry summer days than formerly was the case. This appears to be one of the most likely causes of the disappearance of the reindeer lichens.'

In the report for 1911, the bailiff Abraham Staaf writes: 'The Lapps' care of the reindeer is lax. The increasing tendency to let the reindeer fend for themselves is a danger to the future existence of the reindeer-herding population. It is not enough that they, by their indifference, cause intolerable conditions in the contacts between the settled population and the Lapps. It also contributes to the fact that the reindeer lichen, especially in the dry summer months, is more than needfully broken and destroyed by the trampling of the reindeer; and since the lichen is so greatly reduced within the county, it is necessary for the Lapps to strive in every way to preserve their mountains.'

In the 1913 report (Staaf 1913), he writes: 'As the principal causes of the current decline of reindeer husbandry, I would put forward:

(1) the Lapps' upbringing, both in the home and at school; (2) their inclination to construct log houses where the entire family comes to dwell throughout the year, and where the children in particular learn habits that make them idle, and incapable of the nomadic life, and of becoming true Reindeer Lapps; (3) the transformation of reindeer husbandry to comprise solely meat production, whereby the Lapps' contact with the reindeer is reduced to a minimum.'

The report for 1933-34 was written by Waldemar Gardham (1935). As to the number of reindeer, he writes, among other remarks: 'On the basis of the stocklists (24,370 animals) and the 1934 reindeer inventory $(29,465$ animals), the reindeer stock can be estimated at between 25,000 and 30,000 animals. On the one hand, this number is greater than the Lapps' lichen grazings in the mountains can stand in the long term, and on the other hand, it is more than is compatible with ordered, friction-free and economic reindeer husbandry.' Most of the Lapp bailiffs undertook voluntarily to reduce the reindeer numbers to the level set by the Crown.

\section{The Saami view of the grazing situation}

Johan Olofsson Turi was a Saami, who was born near Kautokeino in the mid-19th century and who migrated to Sweden. At an early stage in his life he was a reindeer herder, though later his predominant interest was hunting and fishing, as well as being a source of income in which the major predators were a central feature. His knowledge of nature and reindeer husbandry in Torne Lappmark was great. In 1908, he obtained the support necessary for him to be able to carry out his dream project-a book about the Mountain Saamis and their life as he had experienced it. The principal supporter of the undertaking was Emilie Demant Hatt, a Danish woman with a great interest in Saami life, and the manager of the mining company Kiirunavaara-Luossavaara AB, Dr. Hjalmar Lundbohm. Lundbohm exercised a great influence on society and cultural life in northern Sweden.

Turi had a command of written and spoken north-Saamish and Finnish, but less so of Swedish and Norwegian. The book 'Muittalus samid birra' (A book about the life of the Saami) was published in Copenhagen in 1910, and comprised both the Saamish text and a translation into Danish by Emilie Demant Hatt. A Swedish translation 'En bok om samernas liv', appeared in 1917. The extracts below deal with reindeer grazing:

'When the reindeer lichen is finished, no other food grows for the reindeer. And the reindeer lichen is finished for no other reason than that the reindeer have consumed it.

-- Nowadays there is little more than the berry bushes up here, where there are so many reindeer, and therefore one must take great care to keep the herd together or to herd the reindeer.

-- The Lapps have now begun to think about their fu- 
ture, and they can now see that the reindeer no longer can live on these areas in Jukkasjärvi and Karesuando, since the reindeer lichen is finished; now the young sons of the Lapps are beginning to look for other occupations.

-- Forty years ago, there was still beautiful white lichen here in the Kattavuoma area (east of lake Torneträsk), so that the whole ground was white. And at that time there were not many nomad villages in Talma, nor in the whole of Jukkasjärvi parish; but when more Lapps began to move in from Karesuando and Kautokeino, the reindeer lichen decreased year by year. And now, when there are so many mountain lemmings, they too have eaten much lichen, and in this way the reindeer lichen has decreased, and is still decreasing. Of this there is proof: if one counts back 25 years, it is easy to recall that there was still plenty of lichen in Talma and in the entire parish of Jukkasjärvi, and now all is, as it were, burnt.

--A Saami knows well enough what his own livelihood is, and he would not wish for any other; but when the Crown has taken the land from the Saami and given it to the farmers, the Crown no longer has power over that land. And thus the Saamis now see that the land on which they may live and graze reindeer, on that land the reindeer can no longer live, for the reindeer lichen is entirely gone.'

The newspaper Samefolkets Egen Tidning (S.E.T.) began to appear regularly in 1919. Its main aim was 'to give its attention to the Saamis, and to see to their economic and cultural interests.' The editor-in-chief from its inception and for many years was Torkel Thomasson, a Saami, born near Fatmomakke in Västerbotten county. Originally a reindeer herder, as an adult he acquired some legal training.

Over the years, S.E.T. often published field reports concerning reindeer forage and reindeer husbandry in the broad sense. In addition to the editor, the authors were active reindeer-herders and others with an insight into questions relating to reindeer husbandry.

The Lapp Commission of 1919, appointed by the government to provide a basis for new legislation concerning reindeer husbandry, the poor-law organisation and the nomad schools administration, made an extensive journey throughout the Saami districts in the summer of 1920, to canvass the views of the Saami population. The editor of S.E.T. took part in this, and in his travel diary, published in S.E.T. Nos. 3 and 4, 1920, gave some information about current grazing conditions. Some of this information was, however, at second hand.

The heathland areas in the coniferous forest between Gällivare and Soppero appeared to him to be heavily grazed; there were only traces of reindeer lichens. The same observation was made along the road between Övre Soppero and Karesuando, where short-stemmed, crooked mountain birch had increasingly usurped the place of coniferous trees in the forests. The mountains in the north are said to have been equally scraped bare of reindeer lichens, as were many other areas, a circumstance which justified the transition within the Saami villages to joint reindeer herding during the spring and summer (S.E.T. No. 4, 1920).

In S.E.T. No. 4, 1921, the editor writes regarding the Oviksfjäll mountains, west of lake Storsjön in Jämtland, that:

'By their nature the Oviksfjäll mountains give the impression of a fertile landscape, both the high mountains and the forest areas around them. The reindeer lichen (South Saamish 'viste') is indeed grazed down, but here it occurs incomparably more abundantly than on the Västerbotten mountains and to the northward of them.'

In S.E.T. No. 4, 1921, the reindeerherder Jonas Torkelsson relates that: 'I came to the Oviksfjäll mountains from Hotagen in 1873. At that time, it seemed as if no Saamis had dwelt on the Oviksfjäll mountains. The reindeer lichen was as good as untouched.' In S.E.T. No. 3, 1922, Torkel Thomasson wrote: 'The fact is that the reindeer lichens on our grazing grounds, principally in the mountains - with few exceptions - is nowadays grazed down, to the extent that the support given to reindeer husbandry by these grazing areas is no more than marginal. Do the natural preconditions for pursuing reindeer husbandry exist in our country?'

The reindeer-grazing convention between Sweden and Norway, which came into force on 1 January 1923, had some consequences for reindeer husbandry in northern Dalarna (Idre), and to some extent also, in the adjacent areas of Härjedalen. The reason was that reindeer strayed into neighbouring areas of Norway from time to time during the snow-free period, which was not regarded favourably by the local people. It was suggested to the county administration in Jämtland that Idre should be closed to future reindeer husbandry. (S.E.T. No. 3, 1925). (cf. Linnaeus 1953)

Naturally, the Saamis in Idre objected to this, and argued for the construction of a fence along the Norwegian border. This would also prevent the movement of reindeer from the direction of Tännäs, which also occurred. There was some support for the suggestion from the county administration in Falun. The desire of the Saamis in Idre to remain there may be explained by the fact that the area has Sweden's richest lichen grazings, as well as on the mountains, with a carrying capacity for many more reindeer than there were in the area at the time. There was, in addition, the advantage that the area was rarely affected by the snow conditions thathinder grazing, in the form of a surface icecrust (flen, tjuohki), which are feared in the northern parts of the reindeer-grazing region (S.E.T. No. 1, 1926).

The opposition of the Saamis led to court proceedings. The lower court found in their favour, but the superior court 

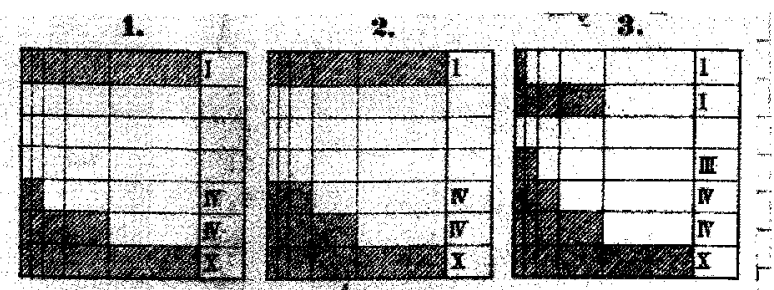

Fig. IB. (In Hult 1881) Investigation sites: 1. - Kittilä, 2, - Turtola, 3. - Kittilä-Isovaara. Pine forests with a complete lichen cover.

found in favour of the county administration in Jämtland. In a judgement dated 28 March 1930, the affected Saamis wer found guilty of illegal reindeer grazing in Idre, and were required to evacuate the area no later than 15 December, and to remove to Tossåsen Saami village, which, from the point-of-view of reindeer husbandry, was a far poorer option (S.E.T. No. 4, 1930).

'By all accounts, reindeer husbandry in this country has now passed its zenith. There are signs that it is declining. The overcrowding in Arjeplog has led to grazed-down lichen fields, and it is no longer attractive for young Saami to devote themselves to reindeer husbandry, with some exceptions. The perpetual conflict over the convention (between Sweden and Norway, concerning questions of reindeer grazing) and much else, causes one to be doubtful.' (S.E.T. No. 3, 1932; Lars Andersson-Spellok, among the Saami villagers appointed assistant bailiff in SemisjaurNjarg Saami village).

'There is overcrowding and the lichen fields are totally grazed down, which indeed is the situation not only within Arjeplog but also in the areas north and south of it.' (S.E.T. No. 3, 1932).

\section{R. Hult's attempt to deduce the laws governing the composition of plant formations}

R. Hult, together with $\mathrm{Hj}$. Hjelt, took part in 1877 in a botanical expedition to northernmost Österbotten and the western part of Kemi Lappmark, Finland (Hult 1881).

At the time (until 1889), the studied area was still open to 'Swedish' reindeer husbandry, carried on by Finnish Saamis, who had recently obtained Swedish citizenship, and who consequently could migrate to Enare as well as to Norway. In addition to the 'Swedicised' Saamis, there were reindeer-herding Saamis who had retained Finnish nationality.

Hult's goal was to contribute to the investigation of 'the laws that determine the composition of plant formations (vegetation types).' The aim thus was not to assess the availability of reindeer forage, but the result is to some extent illuminating even in that respect. The method cho- sen was to estimate the abundance of the formations and species according to a five-point scale:

$\begin{array}{ll}\text { Rr and } \mathbf{r} & \text { rare } \\ 1 \text { and } 2 & \text { occasional } \\ 3 \text { and } 4 & \text { scattered } \\ 5-7 & \text { frequent } \\ 8-10 & \text { abundant }\end{array}$

The basic formations were.

$\begin{array}{ll}\text { I. } & \text { Coniferous trees } \\ \text { II. } & \text { Broadleaved trees } \\ \text { III. } & \text { Shrubs } \\ \text { IV. } & \text { Dwarf shrubs } \\ \text { V. } & \text { Grass } \\ \text { VI. } & \text { Herbs } \\ \text { VII. } & \text { Creepers (absent) } \\ \text { VIII. } & \text { White mosses } \\ \text { IX. } & \text { Liverworts } \\ \text { X. } & \text { Lichens }\end{array}$

The results from each sample area were presented partly as grid diagrams divided into horizontal and vertical cells. The horizontal direction showed the stratification of the vegetation and its abundance. The vertical direction showed the basic formation. Among the most northerly sites investigated were three pine stands situated at Kittilä, Turtola and Kittilä Isovaara.

As is shown in Fig. IB (In Hult 1881), the cover of ground lichens was rich. At Kittilä, Stereocaulon paschale occurred abundantly. Cladonia spp., Cladina spp., Cetraria spp. were occasional. At Turtola, Cladina arbuscula was abundant, $C$. rangiferina frequent, Nephroma arcticum was occasional and Stereocaulon sp., Cladonia spp. and others were sparse.

At Kittilä-Isovaara, Cladina arbuscula was frequent, and Cladonia spp., Cladina rangiferina, C. stellaris and Stereocaulon spp. and others were scattered.

The results of an inventory of four pine heaths in the vicinity of Kolari, between Turtola and Kittilä, and from exposed bedrock areas above the tree limit on Ylästunturi at ca. $900 \mathrm{~m}$ above sea level also showed a complete lichen cover with a similar species assemblage. This gives reason to infer that the grazing pressure in this area, close to the Swedish reindeer-husbandry region, was low at the end of the 19th century. 


\section{The 1909 Commission on Reindeer Grazing Lands}

The 1909 Commission on Reindeer Grazing Lands carried out field studies in 1910 and 1911 regarding the supply of, and access to, reindeer forage within the Saami villages in Torne Lappmark which make use of grazing lands in Norway during the summer. The studies were part of the preparatory work for a new convention between Sweden and Norway, covering the trans-border reindeer husbandry. The inventory methods and some results, taken from 'Proceedings of the 1909 Commission on Reindeer Grazing Lands', are summarised below:

I. In consideration of differences in topography, soil and vegetation, and with regard to their varying importance to the reindeer husbandry, the study areas are divided into zones

(1) The coniferous forest zone (S-zone)

(2) The mountain birch forest zone (FS-zone)

(3) The montane heath zone (V-zone)

(4) The high-mountain zone (H-zone)

II. The fieldwork was based on line transects. For practical reasons, e.g. accessibility, the transects could not be laid out parallel. Emphasis was placed on 'all forest types, terrain and extent of vegetation in which they might be represented within each individual area'.

III. 'The percentage occupied by the forage types lichen and grass-herb forage, and their quality, as also of moss, dwarf shrubs and rock exposures along the transect, was recorded directly.' Occasionally, when the transects traverseddry sites to too large an extent, some adjustments were made, following discussion. 'These adjustments were made in each individual case according to the unanimous decision of the commission.'

IV. The inventory distinguished four main classes:

(1) Sites unsuitable for grazing

(2) Moss and dwarf shrubs

(3) Lichen grazings

(4) Grass-herb grazings

Restriction to these main classes was determined by difficulties in correctly distinguishing between all of the transitional forms that exist. It may be of particular interest to touch upon the commission's definition of lichen grazing grounds:

'... in the term lichen grazing grounds the commission includes all sites that are covered to varying degrees with ground lichens, that are suitable for reindeer grazing'.

The relative value of the lichen ground was classified as follows:

(1) small remains (or sparse traces) of lichen

(2) remains (or traces) of lichen

(3) lichen of abundance 1

(4) lichen of abundance 2, etc., up to abundance 10

By lichen of abundance class $1(y=1)$ is understood a lichen grazing that may indeed be grazed down, but nonetheless no more severely than that it can be considered satisfactory when snow and ground conditions are not a hindrance to grazing. - Lichen of abundance class $2(y=2)$ provides good grazing when grazing conditions are not a hindrance. - Lichen of abundance class $3(y=3)$ can be regarded as very good grazing, which provides necessary nutriment, even when ground conditions are a hindrance. -Lichens of abundance classes 4-8 have been encountered exceptionally, and then only on small patches, which probably are protected from reindeer grazing. Small remains or sparse traces of lichen and remains or traces of lichen may on average be regarded as equivalent to $1 / 3$ and $2 / 3$ of class $y=1$. The sub-classes most commonly represented in the study area are 'small remains or sparse traces' and 'remains or traces'. They occur both on sites heavily grazed by reindeer, and in moss-dwarf shrub vegetation in the form of small lichen patches with taller fruiting bodies. Lichens of abundance class 1 , and exceptionally of class $y=2-3$ mainly occur in forested areas.

The inventory of the lichen resources within the mountain birch forest and montane heath zones in the Saami villages Talma, Saarivuoma, Lainiovuoma and Könkämä, the 'northern villages', is summarised in the tables below. Information concerning lichen grazings in these villages, which has been obtained under other circumstances and on other occasions, will be presented in a later section.

The zone of mountain birch forests, the FS-zone, appears to correspond most closely to the mountain birch forests described by Andersson et al. (1978-1984) and Påhlsson (1998). The zone of montane heaths (the Vzone) is comparable with the heaths described by the same authors. This zone is absent from the surveyed part of Talma.

As Tables 2A-D show, the lichen resources in 'the mountain birch forest' and 'montane heaths' were very limited. The commission's assessment was that the resources in none of the villages corresponded even remotely to the requirements of the existing numbers of reindeer. 'The nomad Lapps' reindeer within the studied areas graze very hard. It is sometimes difficult to understand how lichens over such great areas came to be so thoroughly grazed down by reindeer.' (1909 Commission on Reindeer Grazing Lands).

The representatives of the Saami villages interviewed by the commission claimed, quite unanimously, that the ruined grazings on the Swedish side of the border were the result of the hordes of reindeer that had poured in from the 
Table 2A. Talma Saami village. Lichen resources in the mountain birch forest zone (FS-zone).

FS-zone

\begin{tabular}{lccc} 
Lichen grazings & $\mathrm{km}^{2}$ & $\%$ of area of lichen grazings & \% of area of region \\
\hline Small remains (or sparse traces) & 544.0 & 84.8 & 58.8 \\
Remains (or traces) & 104.5 & 14.9 & 6.6 \\
Abundance =1 & 53.6 & 7.6 & 3.4
\end{tabular}

Table 2B. Saarivuoma Saami village. Lichen resources in the mountain birch forest zone (FS-zone) and montane heath zone (V-zone), respectively.

\begin{tabular}{lccc}
\hline FS-zone & $\mathrm{km}^{2}$ & \% of area of lichen grazings & \% of area of region \\
Lichen grazings & & & 34.3 \\
& 583.9 & 77.5 & 9.5 \\
Small remains (or sparse traces) & 94.1 & 1.5 & 1.1 \\
Remains (or traces) & 10.4 & & 51.3 \\
Abundance =1 & & 97.7 & 1.2 \\
V-zone & 390.1 & 2.2 & 0.0 \\
Small remains (or sparse traces) & 8.9 & 0.1 & \\
Remains (or traces) & 0.2 & & \\
Abundance =1 & & & \\
\hline
\end{tabular}

Table 2C. Lainiovuoma Saami village. Lichen resources in the mountain birch forest zone (FS-zone) and montane heath zone (Vzone).

\begin{tabular}{lccc}
\hline FS-zone & $\mathrm{km}^{2}$ & \% of area of lichen grazings & \% of area of region \\
Lichen grazings & 305.5 & 73.2 & 51.9 \\
\hline Small remains (or sparse traces) & 79.6 & 19.1 & 13.6 \\
Remains (or traces) & 32.1 & 7.7 & 5.5 \\
Abundance =1 & 0.2 & -- & - \\
Abundance =2 & & & 47.0 \\
V-zone & 347.4 & 96.2 & 3.8 \\
Small remains (or sparse traces) & 27.8 & 7.4 & \\
Remains (or traces) & & & \\
\hline
\end{tabular}

Table 2D. Könkämä Saami village. Lichen resources in the mountain birch forest zone (FS-zone) and montane heath zone (V-zone).

\begin{tabular}{lccc}
\hline $\begin{array}{l}\text { FS-zone } \\
\text { Lichen grazings }\end{array}$ & $\mathrm{km}^{2}$ & \% of area of lichen grazings & \% of area of region \\
\hline Small remains (or sparse traces) & 311.5 & 64.4 & 48.1 \\
Remains (or traces) & 107.4 & 22.2 & 16.6 \\
Abundance =1 & 59.3 & 12.2 & 9.2 \\
Abundance =2 & 4.7 & 1.0 & 0.7 \\
Abundance =3 & 0.8 & 0.2 & 0.1 \\
V-zone & & & 45.3 \\
Small remains (or sparse traces) & 547.4 & 91.7 & 3.6 \\
Remains (or traces) & 43.9 & 7.4 & 0.5 \\
Abundance =1 & 5.6 & 0.9 &
\end{tabular}

north. 'Aged Lapps relate that in their youth (before the mid-19th century) the land was still white with lichens, but that two or three decades after the incursion of the Kautokeino Lapps in the 1850 s and 1860 s, this began to decrease markedly.' Still more striking was the deterioration of the lichen grazings after the closure of the Finnish border (1889). Then, the large herds of the Rommavuoma and Suondavaara Saamis, which in former times had regularly spent the winter in Finland, could no longer be taken there, for fear of the brusque methods of the Finnish officials. 
These reindeer, too, must now graze in Sweden.

'Formerly, every area was worked over by the herds but once during the winter. It was also possible to leave some areas completely untouched. At the present time, an area is worked over both during the migration to the coniferous forests, and in the late-winter migration to the mountains. Indeed, it happens that some areas are worked over three or four times during the winter, by herds from several villages.' (op.cit.)

In theopinion of the Saamis, it was necessary to reduce the numbers of reindeer, so that the grazing grounds would not be worked over more than once each winter, thus avoiding further deterioration, which threatens to make reindeer husbandry impossible. Furthermore, it would be desirable that some areas should be left untouched in some years, to recover. The number of reindeer must nevertheless be reduced. Some consider a reduction by half, others by at least one-third. In their opinion, it might be possible to to attain the same result if the area of winter grazings were doubled and, above all else, if they were protected from grazing by forest reindeer throughout the year (ibid.)

\section{Observations on reindeer grazing during the 20th cen- tury, by botanists working in the mountains}

During the summers of 1905-1912, Thore C.E. Fries, partly accompanied by and in cooperation with E. Bergström and S. Mårtensson, carried out extensive studies of vegetation conditions in Torne Lappmark. In the summer of 1908, the reindeer's choice of forage plants was investigated. In the winter of 1909, long journeys were made in the study area, in company with reindeer-herding Saamis. The aim was to study both reindeer husbandry in winter, and the effects of the snow-cover on the vegetation.

Among the results of this work can be mentioned a vegetation map tailored to the needs of reindeer husbandry, at a scale of 1:200,000 (Fries \& Bergström 1909, in Lönnberg 1909, Fig. XI), sections on the reindeer's choice of forage plants and on conditions for reindeer husbandry in the 'northern villages' in Lönnberg (1909), and a doctoral thesis (Fries 1913).

In Lönnberg's publication (1909), Fries concluded that the winter grazings in the coniferous forest region sufficed for the then existing stock of reindeer in the 'northern villages'. However, grazing pressure was intense, as was shown by the shortness of the lichens. As regards the autumn and spring grazings above the coniferous forest limit, the situation was worse; forage was very scarce. It consisted of sparse and short lichens, clumps of Empetrum hermaphroditum and scattered tussocks of grass - where there was any vegetation at all. Through the trampling of the reindeer, and the effects of the wind, a large part of the ground was devoid of all plant cover.

In his doctoral thesis (Fries 1913), he gave an account of the vegetation above the coniferous forest limit in the
Table 3A.Plant cover on sample plots in three lichen-rich vegetation types (Fries 1913): I. Empetrum-rich lichen birch forest at Kelottijärvi, 30 km WNW of Karesuando; II. Heath-like lichen birch forest. Tavvaskaite, S slope; III. Lichen-rich Empetrum heath, W of Kiepenjåkkå by the 'Barrier lake'. Vegetation layer: $a=$ upper tree layer $(>6 \mathrm{~m}) ; \mathrm{b}=$ lower tree layer $(2-6 \mathrm{~m}) ; \mathrm{c}=\mathrm{shrub}$ layer $(0.8-2 \mathrm{~m})$; $\mathrm{d}=$ upper field layer $(0.3-0.8 \mathrm{~m})$; e=intermediate field layer $(0.1-0.3 \mathrm{~m}) ; \mathrm{f}=$ lower field layer $(0.03-0.1 \mathrm{~m})$; $\mathrm{g}=$ ground layer $(0-0.03 \mathrm{~m})$.

\begin{tabular}{|c|c|c|c|c|}
\hline \multicolumn{4}{|c|}{ Vegetation } & \multirow{2}{*}{ III. } \\
\hline b & Betula odorata & $\begin{array}{l}\text { I. } \\
2\end{array}$ & $\frac{\text { II. }}{1}$ & \\
\hline c & Betula odorata & 2 & 2 & - \\
\hline$d$ & Calamagrostis lapponica & . & 1 & - \\
\hline \multirow[t]{4}{*}{ e } & Festuca ovina & - & 1 & - \\
\hline & Juncus trifidus & - & 1 & - \\
\hline & Luzula arcuata & - & 1 & - \\
\hline & Calamagrostis lapponica & - & - & 1 \\
\hline \multirow[t]{8}{*}{$f$} & Empetrum nigrum & 2 & 2 & 3 \\
\hline & Arctostaphylos al pina & 1 & & 1 \\
\hline & Lycopodium complanatum & 1 & - & - \\
\hline & Betula nana & - & 1 & 1,5 \\
\hline & Vaccinium vitis idaea & 1 & 1 & 1 \\
\hline & Myrtillus uliginosa & & - & 1,5 \\
\hline & Festuca ovina & - & - & 1 \\
\hline & Pedicularis lapponica & - & - & 1 \\
\hline \multirow[t]{30}{*}{$\mathrm{g}$} & Polytrichum juniperinum & + & + & + \\
\hline & + Polytrichum cfr. piliferum & 3 & + & + \\
\hline & + Dicranum sp. & 1 & 3 & 3,5 \\
\hline & Cladonia rangiferina al pestris & 3 & + & + \\
\hline & + Cladonia rangiferina vulgaris & 1 & + & + \\
\hline & + Cladonia rangiferina silvatica & 1 & 3 & 4 \\
\hline & Stereocaulon paschale & 2 & 1 & 1 \\
\hline & Lecanora tartarea & 1,5 & 3 & \\
\hline & Cetraria cucullata & 1 & 1 & + \\
\hline & Cetraria islandica & 1 & 1 & + \\
\hline & Cetraria nivalis & 1 & 3 & 3 \\
\hline & Cladonia bellidiflora & 1 & 1 & - \\
\hline & Cladonia cenotea & 1 & - & - \\
\hline & Cladonia coccifera & 1 & 1 & 1 \\
\hline & Cladonia decorticata & 1 & 1 & - \\
\hline & Cladonia deformis & 1 & 1 & 1 \\
\hline & Cladonia furcata crispata & 1 & - & + \\
\hline & Cladonia gracilis cornuta & 1 & - & 1 \\
\hline & Cladonia pyxidata & 1 & 1 & 1 \\
\hline & Cladonia uncialis & 1 & 2 & 3 \\
\hline & Lecanora hypnorum & 1 & 1 & 1 \\
\hline & Lecanora tartarea & - & - & 1 \\
\hline & Pertusaria dactylina & 1 & - & 1 \\
\hline & Phyllocladien + sterile crustaceous lichens & 1 & - & 3 \\
\hline & Alectoria ochroleuca rigida & - & 1,5 & 1 \\
\hline & Alectoria divergens & - & 1 & 1 \\
\hline & Alectoria nigricans & - & 1 & 1 \\
\hline & Solorina crocea & - & 1 & - \\
\hline & Peltigera rufescens & - & - & 1 \\
\hline & Thamnolia vermicularis & - & - & 1 \\
\hline
\end{tabular}

Cover: 1 =occasional; $2=$ scattered; $3=$ sparse; $4=$ rich; $5=$ abundant. 
Table 3B. Bergfors 1: heath-like lichen birch forest, $487 \mathrm{~m}$ a.s.l.; Bergfors 2: Myrtillus nigra-rich lichen birch forest, $485 \mathrm{~m}$ a.s.l.; Kopperåsen: on lichen-rich Empetrum nigra-heath, $430 \mathrm{~m}$ a.s.l.; Riksgränsen 1: on lichen-rich Myrtillus nigra-heath, $470 \mathrm{~m}$ a.s.l.; Riksgränsen 2: on lichen-rich Myrtillus nigra-heath, $480 \mathrm{~m}$ a.s.l. (for explanations see Table 3C).

\begin{tabular}{|c|c|c|c|c|c|c|c|c|c|c|}
\hline & \multicolumn{2}{|c|}{ Bergfors 1: } & \multicolumn{2}{|c|}{ Bergfors 2: } & \multicolumn{2}{|c|}{ Kopperåsen: } & \multicolumn{2}{|c|}{ Riksgränsen 1} & \multicolumn{2}{|c|}{ Riksgränsen 2} \\
\hline & $\mathrm{c}$ & $\mathrm{h}$ & $\mathrm{c}$ & $\mathrm{h}$ & $\mathrm{c}$ & $\mathrm{h}$ & c & $\mathrm{h}$ & $\mathrm{c}$ & $\mathrm{h}$ \\
\hline Cladina stellaris & $\mathrm{E}$ & & $\mathrm{T}$ & 31 & - & & E & & $\mathrm{E}$ & \\
\hline C. rangiferina & $\mathrm{E}$ & & $\mathrm{E}$ & 29 & $\mathrm{~T}$ & 15 & $\mathrm{~T}$ & 39 & $\mathrm{~T}$ & 41 \\
\hline C. arbuscula/C. mitis & $\mathrm{S}$ & 30 & $\mathrm{~T}$ & & $\mathrm{~S}$ & 26 & S & 41 & $S$ & 39 \\
\hline Cladonia uncialis & $\mathrm{T}$ & & $\mathrm{T}$ & & $\mathrm{E}$ & & $\mathrm{T}$ & & $\mathrm{T}$ & \\
\hline Stereocaulon paschale & $S$ & 24 & T-S & 24 & $\mathrm{E}$ & 30 & $S$ & 30 & S & 40 \\
\hline
\end{tabular}

northern part of Torne Lappmark. Hult's scale (Hult 1881) was the basis for the description of cover and for the division into vegetation strata.

The descriptions of the vegetation were related to 'representative' sample plots of varying size in existing plant communities. As examples here have been chosen the description of the lichen cover in the lichen-rich mountain birch forest-valuable for grazing - and the lichen-rich montane heaths, respectively.

Nine types of lichen-rich mountain birch forest were distinguished, on the basis of the characteristics of the tree layer, the presence of a shrub layer, the dominant species of the field layer, and lichen dominance in the bottom layer.

On one sample plot, Cladina spp. and Cetraria nivalis were scattered in the lowest field layer. In the bottom layer of all plots, there were single/scattered individuals of a considerable number of lichen species.

Fifteen types of lichen heath were distinguished. The classification was based on the dominance of lichens and vascular plants, respectively, in the field and bottom layer. The absence of vascular plants gave a sixteenth type - the pure lichen heath. On two only of the plots classified as lichen heath did lichens appear in the field layer, viz. in lichen-rich Cassiope tetragona heath and Diapensia lap- ponica heath. The occurrence in the bottom layer of a large number of lichen species of varying value as forage plants, was noted. On half of the plots, important forage species occurred scattered or even richly, but were of low stature.

Fries considered that the role of reindeer as a major contributor to the degradative effects of wind erosion on the lichen heaths of Torne Lappmark was beyond doubt. On the extensive, sandy plateaux in the alpine region, intensive reindeergrazing and wind erosion together had given rise to large, bare patches. To this process, Fries' contemporaries could bear witness, for they had during their lifetime seen the vegetation disappear from areas where the reindeer lichens previously had formed a continuous carpet.

\section{Tengvall's measurements of reindeer lichen growth}

In the years 1916-1919, commissioned by the Interior Ministry, T.Å. Tengvall investigated lichen growth in the northernmost Saami areas (Tengvall 1928). The method used was serial measurement of the height increment of species protected from reindeer grazing. Enclosed sample plots were laid out at seven sites along the railway between Gällivare and Riksgränsen, three of which were below the coniferous forest limit. In the present context, attention

Table 3C. The sample plots along the south side of lake Tometräsk, at the start of the project in 1914. Lichen cover and height. Cover (c), $\mathrm{E}=\mathrm{occasional}, \mathrm{T}=$ scattered, $\mathrm{S}=$ sparse, $\mathrm{R}=\mathrm{rich}, \mathrm{Y}=$ abundant and Height $(\mathrm{h})$ in $\mathrm{mm}$ of lichen thalli. Bergfors 1: heath-like lichen birch forest, $487 \mathrm{~m}$ a.s.l. Bergfors 2: Myrtillus nigra-rich lichen birch forest, $485 \mathrm{~m}$ a.s.l. Kopperåsen: on lichen-rich Empetrum nigra-heath, $430 \mathrm{~m}$ a.s.l. Riksgränsen 1: on lichen-rich Myrtillus nigra-heath, $470 \mathrm{~m}$ a.s.l. Riksgränsen 2: on lichen-rich Myrtillus nigra-heath, $480 \mathrm{~m}$ a.s.l.

\begin{tabular}{|c|c|c|c|c|c|c|c|c|c|c|}
\hline & \multicolumn{2}{|c|}{ Bergfors 1} & \multicolumn{2}{|c|}{ Bergfors 2} & \multicolumn{2}{|c|}{ Kopperåsen } & \multicolumn{2}{|c|}{ Riksgränsen 1} & \multicolumn{2}{|c|}{ Riksgränsen 2} \\
\hline & $\mathrm{c}$ & $\mathrm{h}$ & $\mathrm{c}$ & $\mathrm{h}$ & $\mathrm{c}$ & $\mathbf{h}$ & c & $\mathrm{h}$ & $\mathrm{c}$ & $\mathrm{h}$ \\
\hline Cladina stellaris & $\mathrm{E}$ & & $\mathrm{T}$ & 31 & - & & $\mathrm{E}$ & & $\mathrm{E}$ & \\
\hline C. rangiferina & $\mathrm{E}$ & & $\mathrm{E}$ & 29 & $\mathrm{~T}$ & 15 & $\mathrm{~T}$ & 39 & $\mathrm{~T}$ & 41 \\
\hline C. arbuscula/C.mitis & $\mathrm{S}$ & 30 & $\mathrm{~T}$ & & $\mathrm{~S}$ & 26 & $S$ & 41 & $\mathrm{~S}$ & 39 \\
\hline Cladonia uncialis & $\mathrm{T}$ & & $\mathrm{T}$ & & $\mathrm{E}$ & & $\mathrm{T}$ & & $\mathrm{T}$ & \\
\hline Stereocaulon paschale & $\mathrm{S}$ & 24 & $\mathrm{~T}-\mathrm{S}$ & 24 & $\mathrm{E}$ & 30 & $S$ & 30 & $S$ & 40 \\
\hline
\end{tabular}


will be concentrated to the plots above this limit, i.e. those situated along an east-west line along the south side of lake Torneträsk, viz.

Cladina stellaris was absent from the plot at Kopperåsen. On the other plots, the cover of the lichens most valuable as reindeer forage was estimated. In summary, it may be stated that the stock of lichens within the research area was small. The degree of cover was in the interval E to T. Cladina arbuscula/C. mitis and Stereocaulon paschale, however, occurred somewhat more richly and had slightly taller thalli.

Harald Smith (1920) carried out fieldwork of a botanical nature in the years 1908-1919, with emphasis on plant-sociological studies in the high-mountain areas of southwestern Jämtland and northwest Härjedalen. Fries (1913) had grouped the heath series plant communities into two parallel sub-series - the lichen-rich and the mossrich. Smith found that this division was not clear within his study area, with the exception of the most continental part-Vättafjäll-Rogstöten. Otherwise, he largely failed to find typical lichen-rich heath, naturally with the exception of heaths of wind-barren type.

At the start of the study, intensive grazing by excessively large reindeer herds had entirely ruined existing heaths. Only on limited areas of block-rich terrain, inaccessible to reindeer, was it possible to see well developed specimens of the larger lichens. Between 1913-1915, the reindeer herds were heavily reduced, at the same time as the management routines were tightened. As a result, Smith considered that he could see a notable increase in lichen biomass on the heaths he had classified as lichen-rich, despite the low growth rate. In comparison with the lichen heaths of the Rogen-Vättafjäll area, they must, however, be considered as markedly poor in lichens.

The first, and from a botanical point of view, possibly the best studied of our montane areas, together with the Abisko mountains, is that part of Lule Lappmark around Kvikkjokk and Virihaure.

Olov Rudbeck the Younger and Linnaeus were the first outside visitors, and after them, the number of visitors to this part of the mountains is almost incalculable. The first investigation of the flora in Lule Lapp@mark of a modern plant-geographical nature, was made by $\mathrm{G}$. Wahlenberg (1812).

During the 1940s, S. Selander (1950) carried out plantgeographical fieldwork in the area between the Sarek and Stora Sjöfallet national parks, which had been the subject of intensive study by Tengwall $(1920,1924,1925)$ and Björkman (1924, 1939). The limit in the south was the areas in which Arwidsson $(1926,1943)$ and Wistrand (1962) had worked.

Selander's study area covered parts of three Saami villages - Tuorpon, Jåkkåkaska and Sirkas, all three of which had a varying use as migration routes, as spring, summer and autumn residences, and-naturally-for reindeer grazing, and then usually during the snow-free period. The number of reindeer that grazed the area during the summer is uncertain. In 1945, when reindeer inventories were carried out, over 13,000 reindeer appear to have grazed there, and of these 3-4,000 had habitually strayed in from Vaisaluokta in the north.

Selander considered that reindeer grazing within his study area did not affect the vegetation to the extent that might be suggested by the large number of reindeer. The reason for this may have been both the tendency of the reindeer to roam widely, their light grazing pressure compared with that of domestic livestock, and their sophisticated choice of forage plants and plant parts ( $c f$. Lönnberg 1909, p. 144; Du Rietz 1924, p. 95).

The observations concerning the relationship between reindeer trampling and wind erosion and exposure of the soil, which Fries (1913, p. 252) had made, were not shared by Selander, who did not note this phenomenon within his study area, which to him appeared to be poor in lichens.

G. Degelius (1943) studied during a few weeks in the summer of 1941 the lichen flora and vegetation in the mountains east and south of Virihaure, an area that was included in Selander's (op. cit.) study area. Degelius considered that the Virihaure area is a part of the mountain chain that is heavily utilised for reindeer grazing, which contributes to the absence of major, continuous lichen heaths.

The factors that principally shape the lichen flora and vegetation around Virihaure are, according to Degelius:

1. Easily weathered and more or less lime-rich bedrock.

2. A limited occurrence of mountain birch forest.

3. The moist climate, which, especially to the westward, gives rise to areas in which the snow thaws late or not at all.

4. Reindeer grazing.

5. The temporary and quite insignificant Saami settlements, which nevertheless lead to some removal of wood and of material for building fences and enclosures, which influences the sparsely occurring birch forests.

The late thaw, which affects some parts of the area, as well as the intensive spring reindeer grazing in other areas, prevents the developments typical of the more continental montane areas, where reindeer grazing does not occure.g. on Fulufjäll and Dovre (ibid.). 


\section{The WWF-project, Background}

\subsection{Project objectives and study sites}

The objective of the main project was to document longterm changes in mountain vegetation. Results obtained should be useful, for example, in the development of methods for environmental monitoring, and in studies of the utilisation of grazing in reindeer husbandry. Consequently, it was appropriate for the work to be concentrated on types of vegetation that are susceptible to wear-and-tear, those that are of great importance for grazing, those that cover large areas, and that can be reliably identified on the available IR photographs from different periods. To provide comparisons, sample plots were laid out in types of vegetation considered less susceptible to wear-and-tear, e.g. moss-rich forests of mountain birch, grass heaths and sub-alpine meadows (Emanuelsson 1984).

To fulfil the aims of the project, a reference group of five experimental areas, spread along the mountain chain, was selected. Reindeerhusbandry and nature-conservation interests were included, together with access to vegetation maps and available older IR aerial photographs. These last were also intended to serve as a basis for remote-sensing studies, to be carried out at the Department of Physical Geography, Stockholm University (Ihse \& Allard 1995). The final report on those studies was published by Allard (2003). The five experimental areas (see map) were given the working names Tavvavuoma, Ritsem, Sånfjället, Långfjället and Fulufjället, and were reconnoitred during the summer of 1993. The southernmost areas are on Fulufjället in Dalarna, and the northernmost are $c a .15 \mathrm{~km}$ south of Tavvavuoma in Lapland.

In 1967-1968, several paired sample plots (a fenced and an open) were laid out in Tavvavuoma (O. Eriksson $e t$ al. 1998), and in connection with field work in 1996, the two in best condition, Puollanvare and Tjuolmajaure (see
Map 1), were incorporated into the project, to illustrate vegetation development over a longer period.

\subsection{Geology}

Table 4 lists the position, height above sea level, solid geology and soil type of all the experimental sites. At all

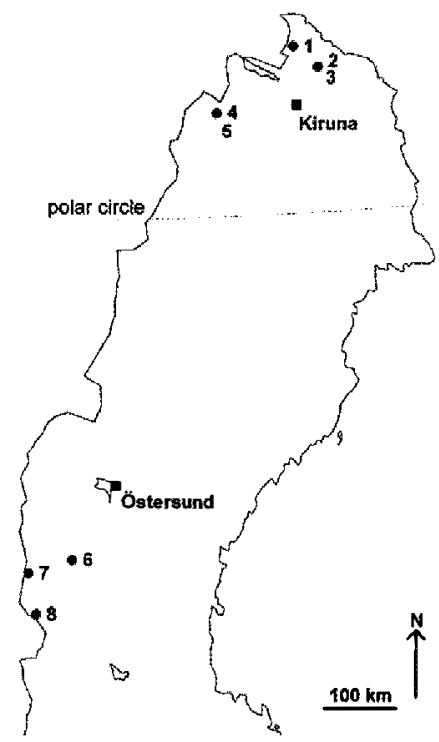

Map 1. Location of experimental areas in the WWF-project along the Scandinavian mountain chain. The experimental areas are located in vegetation types which are assessed to be susceptible to deterioration, of importance for grazing, covering large areas, and are identifiable on available IR-photographs. The areas are (working name/Saami village): 1. Tjuolmajaure/Lainiovuoma, 2. Poullanvare/Lainiovuoma, 3. Tavvavuoma/Lainiovuoma, 4. Ritsem/Mellanbyn, 5. Ritsem/Sörkaitum, 6. Sånfjället/Mittådalen, 7. Långfjället/Idre Nya Sameby, and 8. Fulufjället.

Table 4. Position, height above sea level, solid geology and soil type (Berggrundskarta över Norrbottens län 2000 (BD), Berggrundskarta över Norrbottenfjällens norra del 1965, Karta över berggrunden i Jämtlands län 1969 (Z), Jordartskarta över Kopparbergs län 1948 (W). National Atlas of Sweden 1994).

\begin{tabular}{|c|c|c|c|c|}
\hline Locality & Latitude, longitude & m a.s.l. & Bedrock & Soil type \\
\hline $\begin{array}{l}\text { Tavvavuoma (T), Bd-prov. } \\
\text { (incl. Poullanvare) }\end{array}$ & $68^{\circ} 20^{\prime}, 21^{\circ} 15^{\prime}$ & $500-575$ & $\begin{array}{l}\text { Metagranodiorite, } \\
\text { Metatonalite }\end{array}$ & $\begin{array}{l}\text { Till and weathered deposits above } \\
\text { timber line }\end{array}$ \\
\hline Ritsem (R), Bd-prov. & $67^{\circ} 45^{\prime}, 17^{\circ} 40^{\prime}$ & $725-800$ & Micaschists & $-"-$ \\
\hline Sonfjället (S), Z-prov. & $62^{\circ} 20^{\prime}, 13^{\circ} 55^{\prime}$ & $910-940$ & $\begin{array}{l}\text { Vemdalen Quartzite } \\
\text { formation }\end{array}$ & $\begin{array}{l}\text { Gravelly wave-washed till, } \\
\text { high boulder frequency }\end{array}$ \\
\hline Långfjället (L), W-prov. & $62^{\circ} 05^{\prime}, 12^{\circ} 25^{\prime}$ & $800-1010$ & Dala granite & Gravelly till \\
\hline Fulufjället (F), W-prov. & $61^{\circ} 30^{\prime}, 12^{\circ} 25^{\prime}$ & $860-930$ & Sandstone & Gravelly till \\
\hline Tjuolma jaure (Tj), Bd-prov. & $68^{\circ} 30^{\prime}, 20^{\circ} 24^{\prime}$ & 865 & Gneiss & Till and weathered deposits above timber line \\
\hline
\end{tabular}


sites except Ritsem, the bedrock is severely weathered and chemically acidic. The sites thus lack the potential to form a suitable substrate for rich vegetation. The soils have podsol profiles throughout, with till and, in some cases, weathered soil at the base. The raw humus layer on the lichen-rich vegetation types is thin $(1-4 \mathrm{~cm})$, whereas it is slightly thicker in the moss-rich stands of mountain birch.

The Ritsem site lies within an area of bedrock made up of mica schist that is soft, relatively easily weathered and locally calciferous, which influences the vegetation.

\subsection{Physical geography}

The sites studied were based on aggregates of both abiotic and biotic parameters. Both Tjuolmajaure and Ritsem are situated within the Northern High Mountain area of Nordland Troms and Lapland. They consist of rounded low mountains, interspersed with mountain plateaux and valleys. The solid geology and soil types are described in Table 4. Mountain birch woodlands become increasingly more frequent to the south and east.

Tavvavuoma is part of the continental forests of Finnmark and Lapland. The area is characterized largely by subalpine-subarctic mountain birch woodlands, with open montane plant communities at higher altitudes. The area consist largely of expanses of mountain and hilly terrain, up to ca. $700 \mathrm{~m}$ a.s. 1 .

Sånfjället, Långfjället and Fulufjället all lie within the southern mountain area, which is characterized as rounded mountains on poor bedrock, with intermediate level areas (Anon. 1977).

\subsection{Climate and weather}

Northwestern Europe, particularly Scandinavia, benefits during the colder parts of the year by an inflow of mild air from the Atlantic (Sjörs 1999). In many respects, the mountain chain functions as a divider between two large climate zones, the Atlantic and the Continental. The warm westerly winds from the Atlantic are forced upwards, and slowed down, by the mountain chain, which has the result that their effect on areas to the east is less than if the mountains were not there. Correspondingly, the mountains prevent the easterly winds from inner Eurasia from affecting the climate too strongly to the west of the mountain chain. As a result, relatively low summer temperatures characterize the mountain region, which has to do with the normal decrease of temperature with height. The winter temperature, however, is relatively high, since it often is higher at higher altitudes than in the valley bottoms in these regions, and because of the maritime influence of the sea to the west ( $\AA$ ngström 1974). Comparisons on an annual basis between calculated temperatures within areas at certain latitudes and certain heights above sea level, with those actually measured, reveal anomalies that, when transferred to maps, show zones with similar temperature climate.

The study sites at Tjuolmajaure and Tavvavuoma are situated within an extensive continental-subcontinental area in the northernmost part of Fennoscandia (Sjörs 1990, Oksanen \& Virtanen 1995). Low winter temperatures and relatively little precipitation, which falls as snow during half the year, characterize the region. Permafrost, in the form of palsa hummocks, is abundant. In many respects, the experimental sites at Sånfjället, Långfjället and Fulufjället are situated in a similar continental-subcontinental region with its centre in Norway, but which extends over northern Dalarna and southwest Härjedalen (Oksanen 1998, Sjörs 1999). The site at Ritsem is located at a high altitude, and the western mountains do not provide an effective barrier to the westerly winds; consequently the climate in this area is to some extent oceanic (Oksanen 1998).

Continentality can be calculated as the sum of the temperature difference between July and January, and between day and night during June (Raab \& Vedin 1995). The Ritsem area will then have an index in the range 25-35,

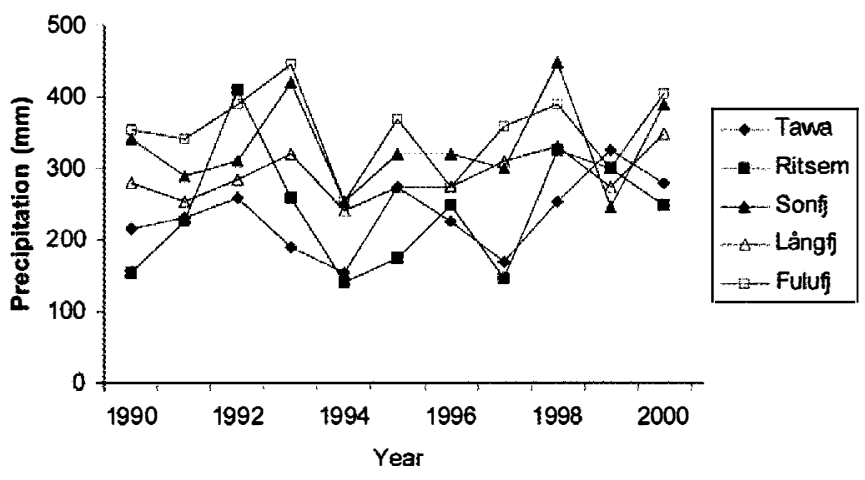

Figure 2. Precipitation during the growing season (daily temperatures $>+3^{\circ} \mathrm{C}$ ) for the years $1990-2000$. The precipitation data were obtained from meteorological stations in Sweden and Norway, not far from the study sites (Table 2). Precipitation (mm) is presented as mean values. 
whereas the other study sites are in the range 35-40. By comparison, the most continental area in Sweden, situated in the inland parts of Norrbotten and Västerbotten, has an index in the range $40-45$, whereas the most maritime area, along the southwest coast, has 20-25.

To calculate the length of the growing season for each study site, the air temperature was weighted with the distance to the nearest meteorological station, according to the following formula:

$$
T=\frac{\sum T_{i} / d_{i}^{2}}{\sum 1 / d_{i}^{2}}
$$

where $T$ is the weighted temperature at the site, $T_{i}$ is the temperature at station $i$, and $d_{i}$ is the distance $(\mathrm{km})$ between station $i$ and the site, as shown in Table 5 .

\section{Growing season}

The growing season, i.e. the period when vegetation is most active with regard to reproduction, growth and dispersal, is usually defined as that part of the year when the daily temperature exceeds, on average, a certain limit. Ångström (1974) gives this as the period (days) during which the daily mean temperature continuously exceeds $+3{ }^{\circ} \mathrm{C}$; it ends when the temperature again falls below the threshold value. Raab \& Vedin (1995) use the threshold value $5^{\circ} \mathrm{C}$. Both of these values are, in fact, based on temperatures considered relevant for agriculture and forestry. A generally applicable threshold value for the mountain region probably does not

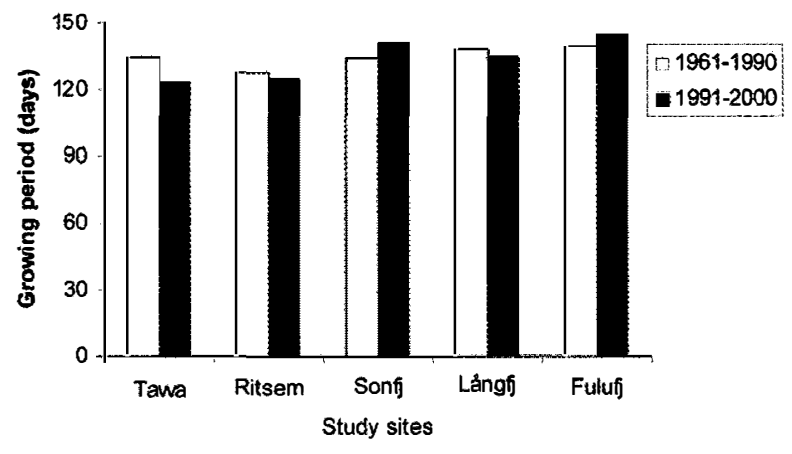

Fig. 3. The length of the growing season (days $>3^{\circ} \mathrm{C}$ ) during 1961-1990 (normal data), and for 1990-2000.

exist, because different plants have differing abilities to withstand extreme temperatures. Good examples are the ground-living Bryoria lichen species, with a dark-coloured thallus that can be photosynthetically active in small melt cavities under a thin snow cover, even if the temperature is low. A condition for this, however, is that there is some contact with layers of air close to the soil, and sufficiently intensive sunshine (Larson \& Kershaw 1975).

The length of the growing seasons during 1961-1990 were calculated according to Morén \& Perttu (1994), and is given in Fig. 3 as the mean of the period's length for vegetation types at the different study sites.

Table 5. Distance $(\mathrm{km})$ between study sites and the meteorological stations used in determining the length of the growing season for each locality.

\begin{tabular}{|c|c|c|c|c|c|}
\hline \multirow[t]{2}{*}{ Meteorological station } & \multicolumn{5}{|c|}{ Sites } \\
\hline & Tavvavuoma & Ritsem & Sonf jället & Långfjället & Fulufjället \\
\hline Katterjåkk & 131 & & & & \\
\hline Naimakka & 38 & & & & \\
\hline Karesuando & 52 & & & & \\
\hline Ritsem & & 15 & & & \\
\hline Nikkaluokta & & 57 & & & \\
\hline Satis & & 49 & & & \\
\hline Stora sjöfallet & & 49 & & & \\
\hline Hede & & & 14 & & \\
\hline Klövsjöhöjden & & & 46 & & \\
\hline Lofsdalen & & & 33 & & \\
\hline Dravagen & & & 33 & & \\
\hline Idre & & 89 & 33 & & \\
\hline Röros & & & & 72 & \\
\hline Drevso & & & & 25 & \\
\hline Särna & & & & & 26 \\
\hline Grundforsen & & & & & 28 \\
\hline Älvdalen & & & & & 70 \\
\hline
\end{tabular}




\section{Humidity}

Precipitation and evaporation, being dependent on temperature, and runoff in large or small waterways, together largely decide the level of moisture in the soil, and thus also the character of the climatic zone. Humidity is of greatest importance during the growing season. De Martonne (1926 a,b,c) created an aridity index (more correctly a humidity index) based on the formula:

$$
H=\frac{P}{T+10}
$$

where $P$ is the annual precipitation ( $\mathrm{mm})$ and $T$ is the mean annual temperature $\left({ }^{\circ} \mathrm{C}\right)$. The constant 10 is used to reduce the influence of temperature on the index slightly, and to make it more useful in colder regions.

According to Ångström (1953a), de Martonne's formula can also be used in a modified form to calculate humidity during periods other than an entire year, e.g. for the growing season.

$H_{v}=\frac{365}{n_{v}} \frac{N_{v}}{10+T_{v}}$

$H_{v}$ is the humidity during theperiod, $n_{v}=$ the number of days in the period, $N_{v}=$ the precipitation and $T_{v}$ the mean temperature during the period. De Martonne's formula possibly gives slightly too high humidity values for some mountain areas where the excess of precipitation over evaporation rapidly runs off on account of the ground's irregularity (Ångström 1953a). Nonetheless, on the whole the maps of the areas agree fairly well with those that show temperature during comparable periods (ibid. 1953a).

B. Eriksson (1986) calculated the share of the precipitation that did not evaporate, but which could benefit the vegetation. This is based on the difference $(\mathrm{mm})$ between precipitation and evapotranspiration. Table 6 shows the humidity climate of the study sites during the growing season, according to de Martonne and Eriksson, respectively. According to Eriksson, the three southernmost study sites are in much moister climatic zones than they are according to de Martonne.

\subsection{Vegetation types}

The underlying bedrock and its weathering capacity influences the composition of the vegetation. On easily weathered basic bedrocks, e.g. limestone, dolomite and mica schist, all of which are nutrient-rich, the vegetation is richer in species than on the more acidic and less readily weathered bedrocks, e.g. granite, gneiss, quartzite and sandstone. Even if lichens do not actively take up nutrients from the soil, they are nevertheless influenced by the bedrock. This is because the minerals influence the composition of the surface water, and thus the nutrients available, in addition to the fact that competition from mosses and vascular plants of ten is considerable on nutrient-rich sites.

In selecting the vegetation types within the study sites, use was made of Vegetationskarta över de svenska fjällen (Andersson et al., 1978-1984) and Vegetationskarta över norra Härjedalens skogsland (Rafstedt 1987). The vegetation classifications used in these maps are based on physiognomic and plant-sociological-ecological factors, as well as on what it is possible to map from available infrared aerial photographs. The vegetation types studied in this project cover all large mountain areas, and are also important grazing areas for reindeer. The linkage of the localities to the aerial photographs, the desirability of gaining access on the ground, and the need for large areas, have sometimes caused the requirement for homogeneous vegetation types to be disregarded.

The study sites situated above the tree limit, i.e. on grass heaths, dry heaths, dry heaths with lichens and meadows with herbs, lie within the low alpine zone, which is delimited at its lower boundary by the woodland formed by Betula pubescens var. czerepanovii. It has a vertical extent of about $300 \mathrm{~m}$, up to the level at which Vaccinium myrtillus ceases todominate, even in situations where there is a reliable, late, thaw (Sjörs 1999).

The present localities lie in the altitude interval $570 \mathrm{~m}$ (Puollanvare dry heath) to $1010 \mathrm{~m}$ (Långfjället grass heath), a range of $440 \mathrm{~m}$ which is approximately equivalent to a difference of six degrees of latitude. The plant cover on the heaths may be more or less fragmented: this depends, e.g. on the degree of exposure, possible trampling and

Table 6. Humidity at the study sites during the growing season.

\begin{tabular}{lcccl}
\hline Study site & Humidity index ${ }^{1)}$ & Character of area ${ }^{2)}$ & Humidity $(\mathrm{mm})^{3)}$ & Character of climate region ${ }^{4)}$ \\
\hline Tjuolmajaure & $28-32$ & Continental & $0-50$ & Weakly humid \\
Tavvavuoma & $28-32$ & Continental & $0-50$ & Weakly humid \\
Ritsem & $48-52$ & Humid & $150-200$ & Very strongly humid \\
Sonfjället & $36-40$ & Moderately dry & $100-150$ & Strongly humid \\
Långfjället & $44-48$ & Subhumid & $150-200$ & Very strongly humid \\
Fulufjället & $44-48$ & Subhumid & $150-200$ & Very strongly humid
\end{tabular}

${ }^{1)}$ Martonne in Ångström (1953a); ${ }^{2)}$ Hesselman in B. Eriksson (1986); ${ }^{3)}$ B. Eriksson (1986); ${ }^{4)}$ Lundin (2003). 


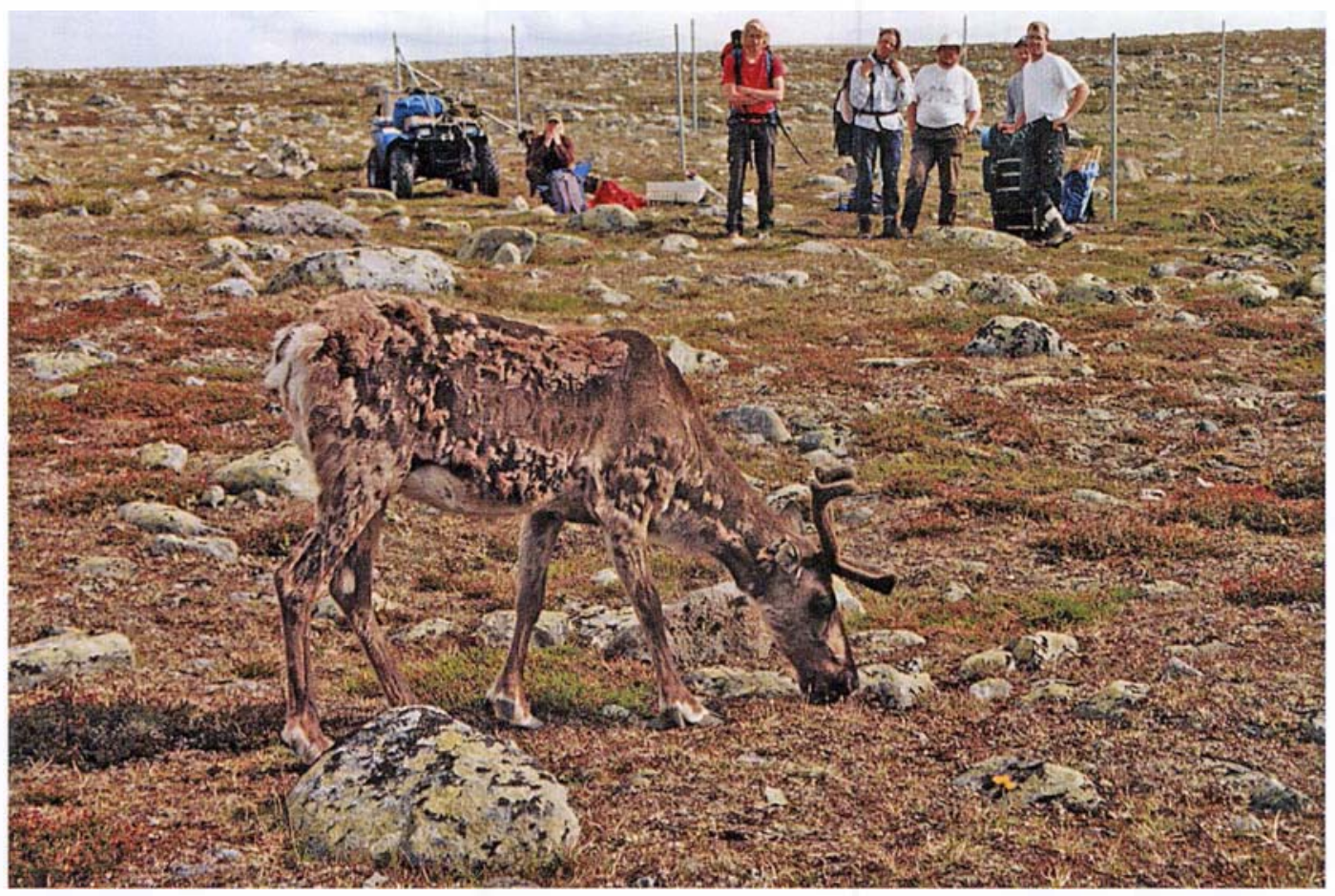

Fig. XXI. A peacefully grazing reindeer outside an enclosed sample plot on Långfjället, being observed by the motor-borne, wandering and botanising human being, yet another important factor that affects the mountain vegetation. The photograph was taken in connection with the revision of the grass heath plot on Långfjället, in the summer of 1998.

grazing by reindeer (Sjörs 1956, 1971, Andersson et al. 1978-1984, Oksanen 1992).

\section{Grass heath}

Thin vegetation, dominated by Carex bigelowii, Deschampsiaflexuosa, Festucaovina and Nardus stricta. There is a gradual transition to dry heath. It occurs mainly in the higher and northern parts of the mountains (Andersson et al. 1978-1984), and differs from the meadow by being well irrigated only during and immediately after snowmelt.

The study site consists of a snow-protected heath of Nardus stricta-C. bigelowii type, Mat-grass type (Påhlsson 1998), that corresponds closest to D. flexuosa-N. stricta heath (Sjörs 1956). The grass heath has a fairly small extent, but has been included in the study for long-term observations of whether it can change, after the cessation of reindeer grazing, to a wind heath of type Cladina alpestris (Påhlsson 1998), or to a wind heath of type Mountain Crowberry (Empetrum hermaphroditum) which, according to H. Mellkvist, County Administration, Falun (pers. comm.), formerly dominated the area.

\section{Meadow with low herbs}

Grass- and herb-dominated vegetation types restricted to soils with relatively long-term protection by snow, and of ten with mobile soil water. The extent is largest within the low alpine region. It changes to species-rich plant communities if influenced by lime (Andersson et al. 1978-1984): Poa al pina-Ranunculus acris meadows with e.g. Bistorta vipara, Parnassia palustris and Bartsia al pina (Sjörs 1999). The abundant (mobile) seepage water gives the meadow vegetation at Mellanbyn the occasional appearance of a fen.

\section{Dry heath}

Dominance of low dwarf shrubs, e.g. Vaccinium myrtillus, Empetrum hermaphroditum and low Betula nana with some narrow-leaved grasses. The closure of the plant cover is generally low, but varies with snow cover. The dry heath type covers large areas in the low alpine region, and changes to species-rich plant communities under the influence of lime.

In the southern mountains, low-growing Calluna vulgaris dominates, with some Empetrum nigrum, Vaccinium vitis-idaea, V. myrtillus, Arctostaphylos alpina and a number of lanceolate grasses. The bottom layer is dominated by Cladonia and Cladina spp. The closure of the plant cover is generally low. A variant in wind-exposed positions is the Dry heath with lichens, where Cladina spp. and Cetraria islandica dominate the plant cover, with some Empetrum hermaphroditum, Calluna vulgaris, Phyllodoce caerulea and Arctostaphylos al pina (Andersson et al. 1978-1984). 


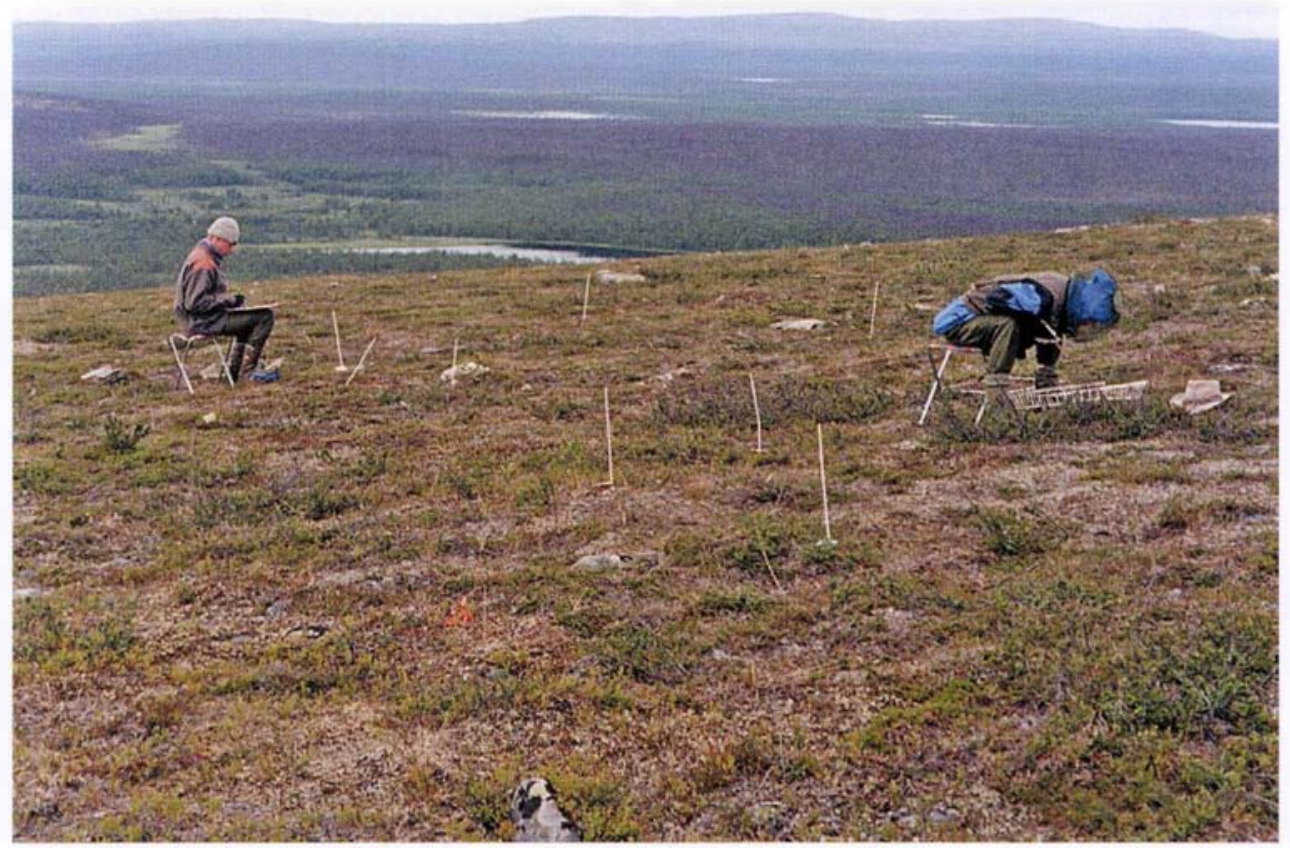

Fig. XXII. The revision of the control plot on Poullanvare in the summer of 1996. The vegetation type is Dry heath. The heath vegetation is dominated by crowberry (Empetrum), and the dominant lichen species is Stereocaulon paschale. In the mountain birch forest below the mountain, large areas damaged by the larvae of the autumnal moths (Oporinia/Epirrita and Operophthera) are visible.

The study areas on Dry heath at Tjuolmajaure, Tavvavuoma (including Puollanvare), Sånfjället and Långfjället are of Mountain Crowberry type (Påhlsson 1998), which corresponds to Flechtenreiche Empetrum ass. (Fries 1913). Vaccinium myrtillus and Cladina spp. benefit from protection against wind and snow. On Fulufjället, only sporadically visited by reindeer herds, as well as Långfjället and Sånfjället, of which the latter two are grazed by reindeer, there is Dry heath with lichens (Andersson 1982) in some areas outside our sites. This corresponds to the Cladina al pestris type (Påhlsson 1998) and Flechtenreiche Betula nana-Gebüsch-ass. (Fries 1913).

\section{Mountain birch forests}

The zone of mountain birch forests in Sweden, covering about $22,000 \mathrm{~km}^{2}$, is largely a northern oceanic phenomenon that forms a distinct altitudinal zone between the coniferous forest limit and the open mountain. Betula pubescens var. czerepanovii completely dominates the tree layer.

Mountain birch forests are found not only in the Scandes, on the Kola peninsula and in the northern Urals, but also on a minor scale on southwestern Greenland, southern Iceland and possibly in Scotland (Sjörs 1956). Several researchers, e.g. Hähmet-Ahti (1963) and Sjörs (1999) today include the mountain birch forests in the fairly heterogeneous, northern boreal subzone-however, as a part that almost entirely lacks conifers. The mountain birch forest is a relatively stable final stage in vegetation development, but can be influenced e.g. by shifts in climate and by the mass occurrence of insects, such as Oporina autumnata and Operophthera brumata (Tenow 1972). The defoliated branches during the winter provide inadequate protection against snow, and in consequence, windbroken trees as well as deep snowdrifts can be seen close together (Sjörs 1971).

The present study sites below the tree limit are situated in high-lying parts of the mountain birch region. The altitude varies between $580 \mathrm{~m}$ (Tavvavuoma) and $940 \mathrm{~m}$ a.s.l. (Sånfjället). At Tavvavuoma and on Sånfjället, the tree layer is completely dominated by Betula pubescens var. czerepanovii, whereas minor occurrences of conifers can be noted on Långfjället and Sånfjället.

Påhlsson (1998) describes four types and seven variants of mountain birch forest. The present study concerns two, viz. Mountain birch forest-dwarf shrub type, which most closely corresponds to birch forest heath type with lichens (Andersson et al. 1978-1984), and Mountain birch forest of dwarf shrub-grass type, which corresponds to birch forest heath type with mosses (op.cit.).

The study areas containing the birch forest heath type with lichens are situated at Tavvavuoma, $520 \mathrm{~m}$ a.s.l., and on Fulufjället at $860 \mathrm{~m}$ a.s.l. (cf. Table 4 ). They cover fairly large areas, mainly in the north, east and inner parts of the mountain chain. On poor and dry land trees of this type of ten have multiple stems, are thin, crooked and 4-6 m tall (Carlsson et al. 1999). Juniperus communis may form a sparse shrub layer. Dwarf shrubs, mainly Calluna vulgaris and Empetrum spp., are found only in 
patches. The plant cover of the bottom layer is dominated by lichens, mainly Cladina spp. (Andersson et al. 1978-84). Fries (1913) coined the name Empetrum-reicher Flechtenbirkenwald. Nordhagen (1943) used the name Betuletum empetro-cladinosum, alternatively Betuletum empetro-hylocomiosum. Sjörs (1971) called it a lichen-rich mountain birch forest.

The birch forest heath type with mosses (Andersson et al. 1978-1984), used in some of the present studies, is found at Tavvavuoma and on Sånfjället, Långfjället and Fulufjället. The altitude varies from $460 \mathrm{~m}$ (Tavvavuoma) to $880 \mathrm{~m}$ a.s.l. (Fulufjället). As regards size, it is the largest of all mountain birch forest types ( $c f$. Table 4$)$, and is found throughout the entire mountain chain (Påhlsson 1998). This type of forest is low, and has an undergrowth of dwarf shrub species such as Vaccinium myrtillus and Empetrum spp., as well as grasses such as Deschampsia flexuosa and herbs, e.g. Solidago virgaurea and Cornus suecica. Mosses are more common than lichens in the bottom layer (Påhlsson 1998). Fries (1913) calls it Moosbirkenwald. Nordhagen (1943) calls it Betuletum myrtillohylocomiosum, Hähmet-Ahti (1963) subalpine Empetrum myrtillus type or subalpine Empetrum type, and Sjörs calls it a blueberry-rich mountain birch forest, or a mountain crowberry birch forest.

\section{Extent of vegetation types studied}

An estimate of the proportion of the selected types of vegetation in the mountain plant cover is given in Table 7. It has been compiled using data from Andersson $e t$ al. (1978-1984), Rafstedt (1987) and Albertsson et al. (1986-87).

The 'mountain area' was delimited by Andersson et al. (1978-1984). It should be noted that some of the low mountains along the eastern edge of the mountain range fall outside the map that covers montane vegetation. Rafstedt (1987) gives an example of a vegetation map of the area to the east of those that are covered by the map of montane vegetation. It illustrates the vegetation on the low mountains Sånfjället, Vemdalsfjällen and Klövsjöfjällen, and that within the surrounding area of northern boreal subzone 'forest' as defined by Sjörs (1999).

A picture of the northern boreal subzone's mountain birch forests outside the mountain range is given by $\mathrm{Al}-$ bertsson et al. (1986-1987). These forests cover ca. 1,900 $\mathrm{km}^{2}$ in northern Norrbotten. The low mountain area Pessinki, with extensive reserves of primeval montane forest, is in this area. Within the northern boreal zone, these forests extend as far as the Norwegian Sea and to the coast of the Barents Sea (Tuhkanen 1980).

Grass heath is found to some extent along the entire mountain range, but has its greatest extent farthest north and in central and southern Norrbotten. It is not known whether this extent is conditioned by climate or whether, as proposed by Påhlsson (1998), it is a result of long-term, intensive grazing by reindeer.

Dry heath is found, as is grass heath, along the entire mountain range, and covers large areas almost everywhere. To a lesser extent it is also found on open areas slightly below the tree limit, where it can form undergrowth in the mountain forests (Sjörs 1956).

Meadows with low herbs form a rather sparsely occurring vegetation type. Only on the map-sheets Sitasjaure and Fatmomakke does the type cover more than $10 \%$ of the ground surface. This vegetation type is restricted to snow-protected ground with mobile ground water (Sjörs 1956).

Birch forest-heath types are found along the entire mountain range, and in northern Norrbotten, also to the east of it. They cover about $22,000 \mathrm{~km}^{2}$. In dry localities with little warmth, they are low (4-6 m) and mainly multiple-stemmed. Single stems, up to $12 \mathrm{~m}$ tall, are found in moist, nutrient-rich sites with good snow protection (Carlsson et al. 1999).

Birch forest-heath types with lichens have their greatest extent in northern Norrbotten, whereas the birch forestheath type with mosses is found along the entire mountain range, although to a lesser extent in the far south.

The dry heath and the birch forest-heath type with lichens at Tavvavuoma and the 'old' dwarf-shrub heath at Puollanvare are all within Saarivuoma Saami village. Tjuolmjaure's 'old dwarf-shrub heath' and Tavvavuoma's moss-rich mountain birch forest are within Lainiovuoma Saami village (here 'old' refers to experiments initiated in 1967-1968). The dwarf-shrub heath at Ritsem is within Sörkaitum Saami village, but the meadow is within Mellanbyn. Sånfjället lies within Mittådalen Saami village, and Långfjället within Idre new Saami village. Fulufjället is completely outside the reindeer-husbandry area, but within the former range of the wild reindeer (Rangifer tarandus L.), now extinct (Lönnberg 1909). This area is now included in the National Park established in 2002. The seven study sites are situated within six Saami villages with varying sizes of reindeer herd. In purely legal terms, all study sites in the Tavvavuoma area are situated within Lainiovouma Saami village. However, a fence which separates the Saami villages and which does not entirely follow the administrative boundary, leads to the result that Saarivuoma's reindeer graze on the dwarf-shrub heath and in the moss-rich mountain birch forest in Tavvavuoma, as well as on Puollanvare's dwarf-shrub heath. 
Table 7. The presence and cover of vegetation types. From: Vegetationskartan över de svenska fjällen (Andersson et al. 1978-1984), Vegetationskarta över norra Härjedalens skogsland (Rafstedt 1987) and Vegetationskarta bladen Karesuando, Soppero and Lannavaara (Albertsson et al. 1986-1987).

\begin{tabular}{|c|c|c|c|c|c|c|c|c|c|c|c|c|c|}
\hline \multirow{2}{*}{\multicolumn{2}{|c|}{ County / Map }} & \multirow{2}{*}{$\begin{array}{l}\text { Area } \\
\mathbf{k m}^{2}\end{array}$} & \multicolumn{2}{|c|}{ Grass heath } & \multicolumn{2}{|c|}{ Dry heath } & \multicolumn{2}{|c|}{$\begin{array}{l}\text { Meadow } \\
\text { with } \\
\text { low herbs }\end{array}$} & \multicolumn{2}{|c|}{$\begin{array}{l}\text { Birch forest - } \\
\text { Heath type } \\
\text { with } \\
\text { lichens }\end{array}$} & \multicolumn{2}{|c|}{$\begin{array}{l}\text { Birch forest - } \\
\text { Heath type } \\
\text { with } \\
\text { mosses }\end{array}$} & \multirow[t]{2}{*}{ Notes } \\
\hline & & & $\mathrm{km}^{2}$ & $\%$ & $\mathrm{~km}^{2}$ & $\%$ & $\mathrm{~km}^{2}$ & $\%$ & $\mathrm{~km}^{2}$ & $\%$ & $\mathrm{~km}^{2}$ & $\%$ & \\
\hline $\mathrm{Bd}$ & 1 Treriksröset & 3550 & 444 & 12.5 & 1402 & 39.5 & 53 & 1.5 & 284 & 3.5 & 694 & 8 & $\begin{array}{l}\text { Tjuolma jaure }{ }^{3)} \\
\text { Tavvavuoma }^{3)}\end{array}$ \\
\hline $\mathrm{Bd}$ & 2 Abisko & 3060 & 337 & 11 & 459 & 15 & 275 & 9 & 0 & 0 & 214 & 7 & \\
\hline $\mathrm{Bd}$ & 3 Rensjön & 2366 & 24 & 1 & 308 & 13 & $<12$ & $<0.5$ & 450 & 19 & 544 & 23 & \\
\hline $\mathrm{Bd}$ & 31L Karesuando & 417.4 & 0 & 0 & 9.4 & 2 & 0 & 0 & 14.9 & 3.6 & 99.9 & 24 & one sheet \\
\hline $\mathrm{Bd}$ & 30K Soppero & 2500 & 21.7 & 1 & 236.1 & 9.4 & 6 & $<1$ & 128 & 5.1 & 858 & 34 & four sheets \\
\hline $\mathrm{Bd}$ & 30L Lannavaara & 2594.4 & 0 & 0 & 68.8 & 0.3 & 0.1 & $<1$ & 63.3 & 2.5 & 746.1 & 28.8 & four sheets \\
\hline $\mathrm{Bd}$ & 4 Sitasjaure & 3110 & 559 & 12 & 591 & 19 & 389 & 12.5 & 0 & 0 & 187 & 6 & Ritsem ${ }^{3)}$ \\
\hline $\mathrm{Bd}$ & 5 Kebnekajse & 2500 & 375 & 15 & 338 & 13.5 & 175 & 7 & 25 & 1 & 200 & 8 & \\
\hline $\mathrm{Bd}$ & 6 Virijaure & 2980 & 536 & 18 & 656 & 22 & 253 & 8.5 & 0 & 0 & $<15$ & $<0.5$ & \\
\hline $\mathrm{Bd}$ & 7 Ö. Sarek & 3500 & 438 & 12.5 & 648 & 18.5 & 53 & 1.5 & 35 & 1 & 403 & 11.5 & \\
\hline $\mathrm{Bd}$ & 8 Sulitelma & 1900 & 266 & 14 & 266 & 14 & 95 & 5 & 0 & 0 & 114 & 6 & \\
\hline $\mathrm{Bd}$ & 9 Kvikkjokk & 2500 & 375 & 15 & 275 & 11 & 75 & 3 & 25 & 1 & 225 & 9 & \\
\hline $\mathrm{Bd}$ & 10 Pieljekaise & 3170 & 380 & 12 & 443 & 14 & 159 & 5 & 0 & 0 & 666 & 21 & \\
\hline Ac & 11 Umfors & 2487 & 137 & 5.5 & 560 & 22.5 & 187 & 7.5 & 0 & 0 & 460 & 18.5 & \\
\hline Ac & 12 Ammarnäs & 2500 & 125 & 5 & 500 & 20 & 125 & 5 & 0 & 0 & 600 & 24 & \\
\hline Ac & 13 Tärna & 2950 & 103 & 3.5 & 339 & 11.5 & 148 & 5 & 0 & 0 & 738 & 25 & \\
\hline Ac & 14 Fatmomakke & 3560 & 178 & 5 & 409 & 5 & 196 & 11.5 & 0 & 0 & 712 & 20 & \\
\hline $\mathrm{Z}$ & 15 Frostviken & 3320 & 17 & 0.5 & 338 & 10 & 68 & 2 & 0 & 0 & 406 & 12 & \\
\hline $\mathrm{Z}$ & 16 Håkafot & 1670 & 8.5 & 0.5 & 142 & 8.5 & 25 & 1.5 & 0 & 0 & 159 & 9.5 & \\
\hline $\mathrm{Z}$ & 17 Kolåsen & 3350 & 100 & 3 & 636 & 19 & 67 & 2 & 0 & 0 & 67 & 2 & \\
\hline $\mathrm{Z}$ & 18 Storlien & 2600 & 156 & 6 & 624 & 24 & 130 & 5 & 0 & 0 & 130 & 5 & \\
\hline $\mathrm{Z}$ & 19 Åre & 3100 & 155 & 5 & 465 & 15 & 31 & $<1$ & 31 & $<1$ & 310 & 10 & \\
\hline $\mathrm{Z}$ & 20 Funäsdalen & 3030 & 61 & 2 & 758 & 25 & 91 & 3 & 91 & 3 & 333 & 11 & \\
\hline \multirow[t]{2}{*}{$\mathrm{Z}$} & 18 D.E.N Härjedalens & & & & & & & & & & & & \\
\hline & 19 D. E skogsland & 5625 & 34 & 0.6 & 360 & 6.4 & 0 & 0 & 73 & 1.3 & 180 & 3.2 & $\begin{array}{l}\text { one sheet } \\
\text { Sånfjället }{ }^{3)}\end{array}$ \\
\hline W & 21 Idre & 2920 & 29 & 1 & 321 & 11 & $<15$ & $<0.5$ & 29 & 1 & 58 & 2 & Långfjället 3) \\
\hline W & 22 Sälen & 3190 & 48 & 1.5 & 239 & $7.5^{2)}$ & 32 & 1 & 16 & 0.5 & 64 & 2 & Fulufjället ${ }^{3)}$ \\
\hline
\end{tabular}

\footnotetext{
1) $\mathrm{Bd}$ - Norrbottens län. $\mathrm{AC}$ - Västerbottens län. $\mathrm{Z}$ - Jämtlands län. $\mathrm{W}-$ Dalamas län;

2) Including $3 \%$ dry lichen dominated heath;

3) Study site.
} 


\section{The WWF-project: How it was carried out}

\section{Establishment of sample plots}

At all study sites except Puollanvare and Tjuolmajaure, a subjective choice was made in 1994 of six adjacent plots, $25 \times 25 \mathrm{~m}$, for each vegetation type, in which the vegetation was considered to be as similar as possible. Ridges and crests were avoided because they make up only a minor part of the total area, and because they are largely affected by both weather and wear-and-tear. The plots were laid out with the diagonals in a north-south and east-west direction and were delimited by corner crosses and corner markers of steel hammered into the soil. To avoid edge effects, all records were later made on $22 \times 22 \mathrm{~m}$ net areas, the corners of which were also marked with steel pegs.

A preliminary ordination approach, based on collected field data, provided a basis for dividing the six sampling plots into pairs with similar vegetation, where one plot was fenced and the other left open. Fences consisted of 170 $\mathrm{cm}$ high reindeer fencing material. Each relevant Nature Management unit decided the type of fence post used. Small herbivores, e.g. rodents and insects, still had free access to the plots.

When the project began in 1994, the vegetation on Fulufjället was considered not to be exposed to measurable external influences, and it was decided that a system of open sample plots could be used. During 1995, however, reindeer were seen on the mountain and droppings were observed. As a result, the sample plots were modified in 1996 to consist of three open and three fenced plots per vegetation type on all study sites.

At Puollanvare and Tjuolmajaure, a pair of plots $12.5 \times 12.5 \mathrm{~m}$ (one fenced and the other open) were laid out on each site in $1967-68$ by O. Eriksson. The identification markings in the terrain were similar to those at other sites (i.e. in the WWF project). Table 8 lists vegetation types, height above sea level, plot size, number of plots, year of establishment, and year of second inventory of each type of vegetation, for all study sites.

Within each fenced plot, a maximum of eight subjectively chosen $0.5 \times 0.5 \mathrm{~m}$ quadrats were selected, and permanently marked for photography at each revision. These quadrats were intended to illustrate the type of vegetation that dominated in the original situation, and subsequently to illustrate any changes in plant composition, degree of cover and frequency of various species in the field layer, that might have occurred.

Table 8. Vegetation type, height above sea level, plot size, number of plots ( $\mathrm{o}=\mathrm{open}+\mathrm{f}=\mathrm{fenced})$, year(s) of establishment, and year of second inventory of each type of vegetation, for all study sites.

\begin{tabular}{|c|c|c|c|c|c|c|}
\hline Site & Vegetation type & $\begin{array}{l}\text { Alt. } \\
(\mathrm{m})\end{array}$ & $\begin{array}{l}\text { area } \\
(\mathrm{m})\end{array}$ & $\begin{array}{l}\text { No. of plots } \\
(0+f)\end{array}$ & Established & 2nd inventory \\
\hline \multirow[t]{3}{*}{ Tavvavuoma } & Dry heath & 580 & $25 \times 25$ & $3+3$ & 1995 & 1999 \\
\hline & Birch forest heath type with lichens & 520 & $25 \times 25$ & $3+3$ & 1995 & 1999 \\
\hline & Birch forest heath type with mosses & 460 & $25 \times 25$ & $3+3$ & 1995 & 1999 \\
\hline \multirow[t]{2}{*}{ Ritsem } & Dry heath & 840 & $25 \times 25$ & $3+3$ & 1995 & 1997 \\
\hline & Meadow with low herbs & 820 & $25 \times 25$ & $3+3$ & 1995 & 1999 \\
\hline \multirow[t]{2}{*}{ Sånf jället } & Dry heath & 910 & $25 \times 25$ & $3+3$ & $1995+1996$ & 1998 \\
\hline & Birch forest heath type with mosses & 940 & $25 \times 25$ & $3+3$ & $1995+1996$ & 1998 \\
\hline \multirow[t]{3}{*}{ Långfjället } & Dry heath & 840 & $25 \times 25$ & $3+3$ & 1995 & 1998 \\
\hline & Grass heath & 1010 & $25 \times 25$ & $3+3$ & 1995 & 1998 \\
\hline & Birch forest heath type with mosses & 800 & $25 \times 25$ & $3+3$ & 1995 & 1998 \\
\hline \multirow[t]{3}{*}{ Fulufjället } & Dry heath & 930 & $25 \times 25$ & $3+3$ & $1995+1996$ & 1999 \\
\hline & Birch forest heath type with lichens & 860 & $25 \times 25$ & $3+3$ & $1995+1996$ & 1999 \\
\hline & Birch forest heath type with mosses & 880 & $25 \times 25$ & $3+3$ & $1995+1996$ & 1999 \\
\hline Poullanvare & Dry heath & 570 & $12.5 \times 12.5$ & $1+1$ & 1967 & 1997,1999 \\
\hline Tjuolma jaure & Dry heath & 865 & $12.5 \times 12.5$ & $1+1$ & 1968 & 1997,1999 \\
\hline
\end{tabular}




\section{Composition of the ground layer}

To assist studies of the field and bottom layers, each net area was mapped and divided into 484 subplots of $1 \times 1 \mathrm{~m}$ ( $0.5 \times 0.5 \mathrm{~m}$ at Puollanvare and Tjuolmajaure). Of these, 20 subplots were randomly chosen and measured, starting from the corner markings of the net plots. The percentage cover of each individual species, of litter, mineral soil, etc., on the subplots was then estimated.

Where species determination and quantification were impossible without destructive sampling, some species were grouped together. One example is the group of juvenile Cladonia/Cladina lichens, which are difficult to determine in the field. Consequently, in what follows, the term 'species' may also include genus, species group or other class.

\section{Shrub and tree layer}

To be able to describe the shrub and tree layer in the net plots for the birch forest-heath type with mosses and birch forest-heath type with lichens, the detailed plan was used to select sixteenareas $5.5 \times 5.5 \mathrm{~m}$, of which six were randomly chosen, and were measured from the corners of the net plot. Estimates were then made of species composition, degree of cover, height, diameter (base, breast, crown) and individual density. Grazing pressure on each subplot was also determined.

\section{Presence of herbivores}

The presence over time of hares, reindeer and elk within the studied plant communities was estimated by counting droppings (Lavsund 1975) in six areas $5.5 \times 5.5 \mathrm{~m}$ per $25 \times 25 \mathrm{~m}$ plot. The age of the droppings was not considered. Traces of browsing in the shrub and tree layer were also noted. These records were not made at the Puollanvare and Tjuolmajaure sites.

\section{Data processing}

Descriptions of the composition of a plant community that include only the number of taxonomic groups (e.g. species) cause vital information on community structure to be ignored. No knowledge is obtained on whether certain species are common or rare. To obtain a measure of species richness in a community, it is customary to use various diversity indices, which not only consider the number of taxa, but also individual degrees of cover, biomass per unit area, or distribution of cover between taxa.

In the present study, use was made of Shannon's diversity index (Shannon 1948), whereby it was possible to calculate species diversity at the different study sites, as well as the types of vegetation according to the formula:

$H=-\sum_{i=1}^{s} \frac{T_{i}}{T_{t}} \ln \frac{T_{i}}{T_{t o t}}$

where $H=$ Shannon's diversity index, $T_{i}=$ cover of a species or group of species, $T_{\text {tot }}=$ total cover of all species and groups of species, and $s=$ the number of identified species/groups of species. The number of taxa found, and how evenly they are distributed in the ground layer, thus determines the value of $H$. The greater the number of taxonomic groups, and the more evenly distributed they are, the higher is the index value. In actual communities, $H$ is of ten between 1 and 6 (Stiling 1996), and maximum diversity occurs when all species have degrees of cover that are of the same magnitude, i.e., $H_{\max }=1 \mathrm{n} s$.

Before the various statistical tests were carried out, the recorded species were divided into groups according to Table 9. The subdivision was based on the occurrence of the species. Those that occur in most vegetation types or which are characteristic of a certain vegetation type, or both, were not grouped, but were treated individually. One vegetation type, Meadow with low herbs in Mellanbyn, was given its own grouping, because its species composition differed more compared with that of the other types.

In the statistical processing of the collected data, the vegetation types birch forest heath type with mosses and

Table 9. Shannon's diversity index for fenced and open plots in the moss-rich birch forest and the dry dwarf-shrub heath at Tavvavuoma, Sonfjället, Långfjället and Fulufjället. In each vegetation type and at each site three fenced and three open plots were studied, each with an area of $22 \mathrm{~m} \times 22 \mathrm{~m}$.

\begin{tabular}{|c|c|c|c|c|c|}
\hline Vegetation type & Plots & Tavvavuoma & Sonfjället & Långfjället & Fulufjället \\
\hline Birch forest with mosses & $\begin{array}{l}\text { Fenced } 1995 \\
\text { Fenced } 1999 \\
\text { Open } 1995 \\
\text { Open } 1999\end{array}$ & $\begin{array}{l}1.867 \\
2.259 \\
1.883 \\
1.948\end{array}$ & $\begin{array}{l}2.399^{1)} \\
2.409^{2)} \\
2.405^{2)} \\
2.508^{2)}\end{array}$ & $\begin{array}{l}2.715 \\
2.471^{2)} \\
2.639 \\
2.532^{2)}\end{array}$ & $\begin{array}{l}2.661^{1)} \\
2.779 \\
2.880 \\
2.724\end{array}$ \\
\hline Dry heath & $\begin{array}{l}\text { Fenced } 1995 \\
\text { Fenced } 1999 \\
\text { Open } 1995 \\
\text { Open } 1999\end{array}$ & $\begin{array}{l}2.291 \\
2.894 \\
2.273 \\
2.924\end{array}$ & $\begin{array}{l}1.757^{1)} \\
2.381^{2)} \\
1.718 \\
2.311^{2)}\end{array}$ & $\begin{array}{l}2.807 \\
2.858^{2)} \\
2.625 \\
2.866^{2)}\end{array}$ & $\begin{array}{l}2.423^{1)} \\
2.483 \\
2.464 \\
2.575\end{array}$ \\
\hline
\end{tabular}


Table 10. Conversion table for the percentage cover of species.

\begin{tabular}{cc}
\hline Cover in percent & Value in PCA \\
\hline $0.0001-2.0$ & 2 \\
$2.1-3.0$ & 3 \\
$3.1-5.0$ & 4 \\
$5.1-12.5$ & 5 \\
$12.6-25.0$ & 6 \\
$25.1-50.0$ & 7 \\
$50.1-75.0$ & 8 \\
$75.1-100$ & 9 \\
\hline
\end{tabular}

dry heath were analysed simultaneously. Thus a a balanced layout, with four replicates for each vegetation type, was obtained. The dry heath in Ritsem was not included in this layout, and was treated separately, because this site lacked the vegetation type birch forest heath type with mosses. The vegetation types birch forest heath type with lichens, grass heath and meadow with low herbs, were also treated individually; the same applies to the sites at Puollanvare and Tjuolmajaure.

\section{Ordination}

To obtain a picture of changes in the composition of the vegetation over the years, we carried out a PCA (principal component analysis) using the program CANOCO version 4.0 (ter Braak \& Šmilauer 1998) for each vegetation type, with all study sites included. An exception was the dry heath at Ritsem, which was treated individually, separately from the other dry heath localities.

The percentage cover of the species/species groups was revised according to a 9-degree scale (Table 10).

All species were present in the analysis. Cover by shrubs, shrub height, cover by trees, tree height and droppings were used as passive environmental variables.

PCA, which is an ordination method for indirect gradient analysis, implies that the two least similar sample plots are chosen and placed one at each end of a line; other plots are then arranged along the same axis, depending on their floristic similarity to the plots at each end. It should be noted that the plots are not arranged along a gradient in the terrain, although it is reasonable to assume that they will nonetheless be dispersed along the most important environmental gradient, since the gradient should correlate with the vegetation's composition.

Naturally, the gradientconcerned depends on the plots at the ends of the line. We may assume, for example, that the gradient is from the birch forest to the open mountain. This gradient may take on different appearances, depending upon topography, soil type, etc. Probably, some of the plots in our imaginary study are in heath vegetation and others in meadow vegetation. Somewhere in the middle of the line we may then find plots which all are close to the tree limit, but which nevertheless are very dissimilar. We can then make another line, on which the plots can be located in a coordinate system with two axes, still with vegetation similarities as the common base. We would then probably have few meadow plots at one end, and heath plots at the other end of this axis.

Thus the final result will be a two-dimensional ordination diagram, with points that identify the different plots. The closer two plots are to each other, the greater is their similarity in vegetation. Species can also be included in the diagram in the same way. Species that usually occur together will then lie in the same part of the diagram. An arrow that starts from the centre represents each species and ambient variable. The arrow for a certain species points towards those plots on which it is most abundant. The length of the arrow is proportional to the degree of cover of the species. If many short arrows point towards the same group of plots, one can conclude that those plots have a high diversity. The direction in which an arrow for a certain ambient variable points is the direction in which this variable increases. If the arrows for two or more ambient variables point in the same direction, we may conclude that those variables are positively correlated.

The diagram may thus be regarded as a graphical summary of basic data. As was mentioned above, plots with similar vegetation are situated close together in the diagram. This means that we can obtain an idea of the magnitude of changes in vegetation with time, by seeing how much the plots have moved in the diagram from year to year. One can also study the effect of different environmental variables on the vegetation composition.

Mathematical descriptions of ordination methods can be found in e.g. ter Braak \& Šmilauer (1998), Orlóci (1978) and Økland (1990).

\section{Cover}

To make a closer study of changes in vegetation with time, we compared the cover values of the species/species groups from the two inventory occasions. The statistical method used was a mixed-model ANOVA from the program package SAS (SAS Institute, 2001). The intention of an ANOVA is to search for significant differences between mean values, by comparing variances.

In a study in which several variables or variable groups are to be compared, an analysis of variance is preferable, e.g. to the $t$-test. A reason for this is that the number of $t$ tests increases as a function of the number of groups, and the more tests are performed, the higher is the probability of making at least one type 1 error in the analysis, i.e. of rejecting the null hypothesis.

The term 'mixed' means that the model tested consists of both fixed variables and random variables. A random variable is characterised by normally consisting of a random selection, e.g. from a population, if a population 
Table 11. Models for mixed-model ANOVA conducted on birch forest heath type with mosses (=BFM) and dry heath (=DH) together, as well as individually on birch forest heath type with lichens $(=\mathrm{BFL})$, Ritsem dry heath $(=\mathrm{DH})$, meadow with low herb (=meadow), grass heath $(=\mathrm{GH})$, Puollanvare (=Poul) and Tjuolmajaure (=Tjuol), where the degree of cover of a species/species group is tested against the influencing factors and the interactions between them.

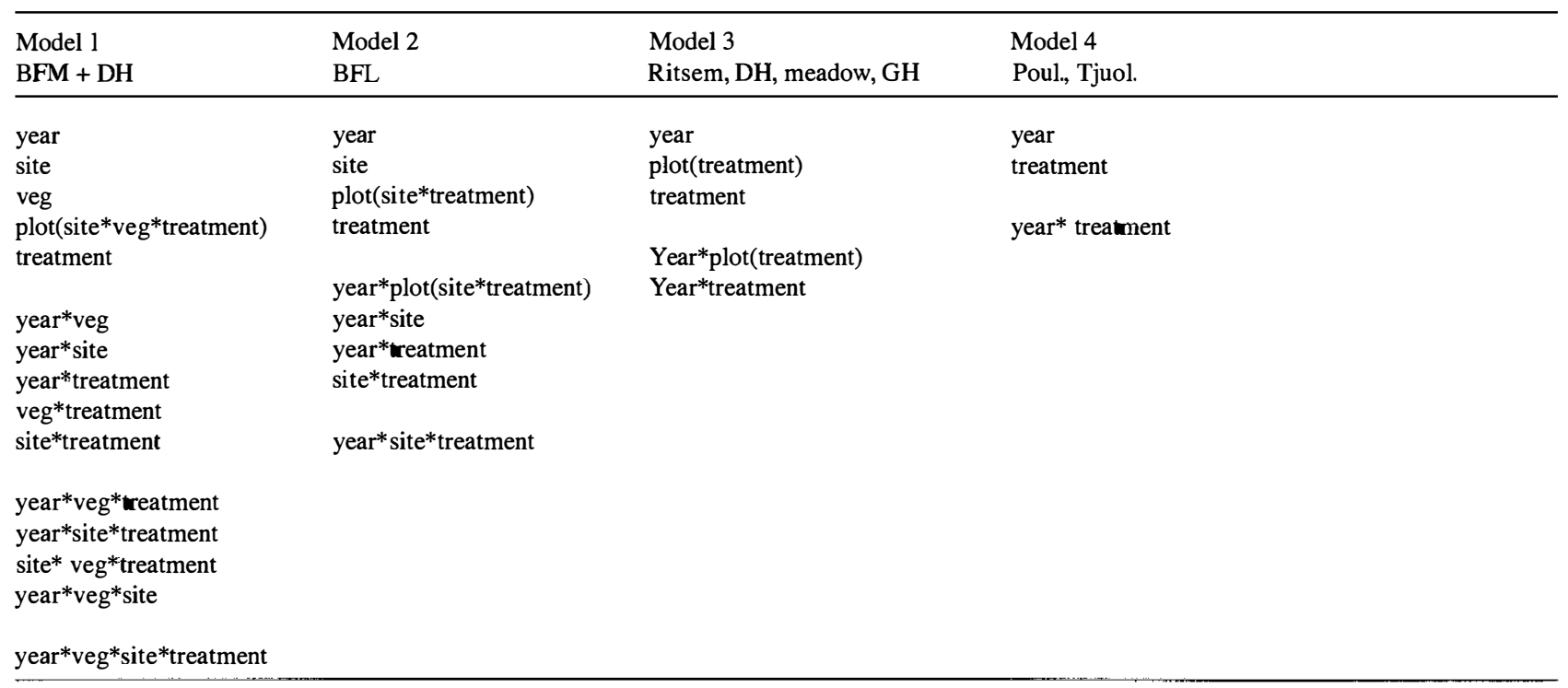

study is concerned. In the present case, the 20 subplots were randomly chosen within a plot $(25 \times 25 \mathrm{~m})$, which means that a 'sample plot' is a random variable. A fixed variable, on the other hand, has the same value or level throughout. The time of the inventory (year 0 and year 1 , respectively), the treatment (fenced or open area, respectively), the site and type of vegetation, are the fixed variables in our study.

For the ANOVA, we converted the cover values for the species and species groups according to the formula:

Transformed degree of cover $=\arcsin \sqrt{\% \operatorname{cover} / 100}$

Since it is not possible tocalculate the arcsin of numbers larger than 1 , the value 100 was used for species groups

Table 12. Model for the mixed-model ANOVA used on the shrub and tree layer in birch forest heath type with mosses and lichens.

\begin{tabular}{l}
\hline Factors \\
year \\
site \\
plot(site*treatment) \\
treatment \\
Year*site \\
Year*treatment \\
Year*area(site*treatment) \\
Site*treatment \\
Year*site*treatment
\end{tabular}

that had a total cover of more than $100 \%$. The transformed degrees of cover then constituted the response variable, which we analysed against different influencing factors and against interactions between the factors. The birch forest heath type with mosses and dry heath were tested together, whereas the dry heath at Ritsem, birch forest heath type with lichens, meadow with low herb, grass heath and the sites at Puollanvare and Tjoulmavare, were tested individually. The complete models for all analyses are given in Table 11.

With the species/species groups in model 1, that showed significant differences in any of the interactions year $x$ treatment, year $\times$ type of vegetation $\times$ treatment, year $x$ site $\times$ treatment and year $\times$ type of vegetation $\times$ site $\times$ treatment, additional models were constructed and analysed. These analyses were made for each type of vegetation, but for one site at a time. In a similar manner we treated the species/species groups in model 2 , that showed significant differences in any of the interactions year $x$ treatment and yearxsitextreatment. The model we used for these tests was the same as model 3 in Table 11. Here, the interaction yearxtreatment is the most interesting, because it can give an indication of any changes in the degree of cover with time as a response to the treatment. The same approach was also used for model 4 .

\section{Frequency}

We also investigated whether there had been any changes in the occurrence (frequency) of a species/species group. The analysis was made by means of the logistic regres- 
sion module from the SAS package (SAS Institute, 2001), and we used the same species and species group as for the analysis of variance (Table 9).

Logistic regression is a variant of common linear regression, and can be used when the response variable is binary, i.e. it can only assume two values (generally 1 and 0 ). The regression examines the relationship between one or more independent variables, and the probability that a response variable will assume a certain value. Examples of a binary variable may be mortality (living $=1$, dead $=0$ ), or the frequency of a species (occurrence $=1$, non-occurrence $=0$ ). Use can also be made of proportions, when they are based on binary data.

We used the occurrence of a species/species group on a large plot as the response variable. For all sites, the same logistic regressions were then calculated, whereby each type of vegetation was treated separately. We tested the response variable against year, area, and treatment, and against the interaction year $\times$ treatment. As with the
ANOVA, we were mainly interested in the interaction year $\times$ treatment.

\section{Shrub and tree layer}

Totrace changes in the shrub and tree layer between years in the moss-rich and lichen-rich birch forests, we used a mixed-model ANOVA. We compared the crown cover of shrubs and trees individually, as also the basal area $\left(\mathrm{m}^{2}\right.$ $\mathrm{ha}^{-1}$ ) of the tree layer. All individuals taller than $200 \mathrm{~cm}$ were treated as trees. The tests were made on each vegetation type individually; the model ANOVA is shown in Table 12.

The variables that showed significant results in any of the interactions year $\times$ treatment and year $\times$ site $\times$ treatment were used in a further ANOVA. This time we tested each site individually, using the model: year, treatment, plot(treatment) and year $\times$ treatment. 


\section{The WWF-project: Results}

\subsection{Birch forest heath type with mosses and dry heath}

Birch forest heath type with mosses are found at the four localities Tavvavuoma, Sånfjället, Långfjället and Fulufjället, whereas dry dwarf-shrub heath is the only type found on all sites studied by the project. As mentioned above, the dry heath at Ritsem was treated separately.

\section{Species present}

Table 13 shows the number of taxa (species, species groups, genus, etc.) found on the two inventory occasions at the different study sites and vegetation types. All taxa are listed in the Appendix I. The fact that some species that are difficult to identify (e.g. juvenile lichens belonging to the genus Cladonia) were grouped together when it was not possible to determine the species, makes for difficulty in deciding from the species list whether such a species actually is present, or whether it has disappeared over the years.

In the Tavvavuoma birch forest-heath type with mosses, we found Salix herbacea, Rubus chamaemorus, Cetraria ericetorum and Bartsia alpina only in the fenced plots in 1995, whereas Cladina stellaris had disappeared from the open plots during the years. Huperzia selago and Lycopodium clavatum were not found in 1995 , but when the plot was re-inventoried they were found on the open plots, and the latter species on both the open and fenced plots. Other species that had arrived by the time of the 1999 inventory were Festuca ovina and Equisetum sylvaticum in the fenced plots and Stereocaulon paschale on the open plots.

Solidago virgaurea, Stereocaulon paschale and Cetraria ericetorum had disappeared from the open plots between the two inventories in Sånfjället's moss-rich birch forest. Arctostaphylos alpinus was not found at the inventories in 1995/96, but was found on the open plots in 1998. Phyllodoce caerulea and Cetraria ericetorum are two new species on the fenced plots.

In Långfjället's birch forest-heath type with mosses, Cetraria nivalis was found on the fenced plots only in 1995, but had disappeared at re-inventory in 1998. Nardus stricta disappeared from the open plots between the inventories, whereas it appeared on the fenced plots. Festuca ovina, Linnea borealis, Arctostaphylos alpina, Nephroma arcticum and Peltigera aphthosa were not found on the open plots in 1995, but were found at re-inventory in 1998; the same applied to Festuca ovina on the fenced plots.

At Fulufjäll, Eriophorum vaginatum was found only on the open plots and Hieracium spp. only on the fenced plots in 1995. Neither was found in 1999. Arctostaphylos alpina was not present in 1995, but had arrived on the open plots in 1999.

The dry heaths at the different sites generally had a larger turnover of species than the birch forest-heath type with mosses. It may be noted that at Tavvavuoma, Phyllodoce caerulea, Diphasiastrum complanatum and Hieracium spp. were found only on the fenced plots in 1995, and that they had disappeared by the time of re-inventory in 1999. Pedicularis lapponica, on the other hand, was found only on the open plots in 1995, but had disappeared by 1999 , and Deschampsiaflexuosa disappeared only from the fenced plots between the two inventories. Examples of newly arrived species on the fenced plots are Solidago virgaurea, Calluna vulgaris, Vaccinium myrtillus and Festuca ovina, whereas Agrostis mertensii was a new species on the open plots.

In the dry heath at Sånfjället, Pleurozium schreberi was found on both fenced and open plots in 1995/6, but

Table 13. Number of taxa for fenced and open areas in the moss-rich birch forest and in the dry dwarf-shrub heath at Tavvavuoma, Sonfjället, Långfjället and Fulufjället. In each vegetation type and in each study site three fenced and three open areas were studied, each with an area of $22 \mathrm{~m} \times 22 \mathrm{~m}$.

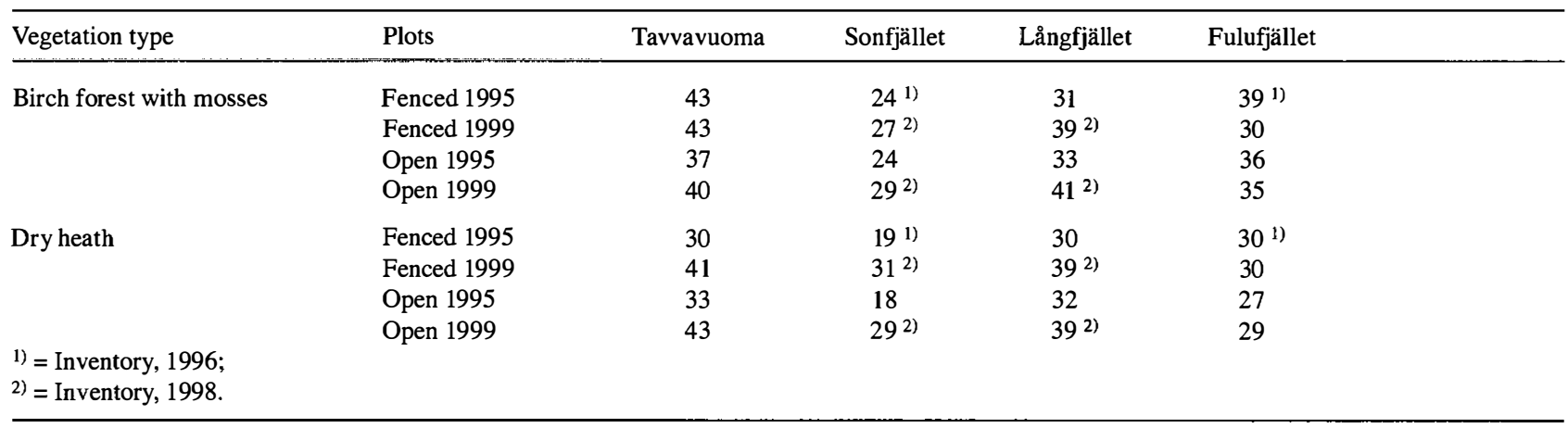



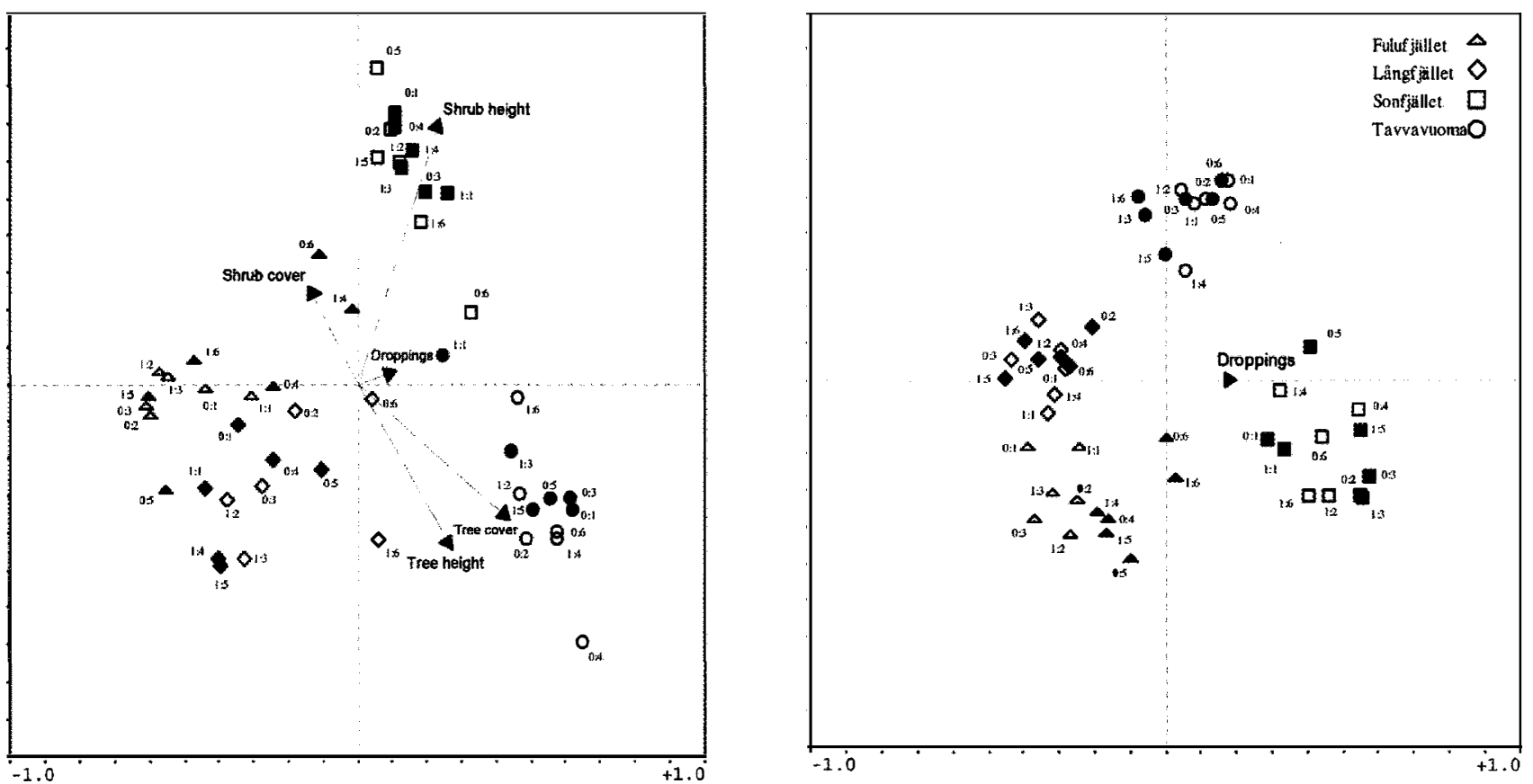

Fig. 4. Ordination diagram (PCA) for study plots in birch forest-heath type with mosses (a) and on the dry heath (b) at Tavvavuoma, Sånfjället, Långfjället and Fulufjället. The first figure in the identification codes of the plots refers to the year of inventory $(0=$ first inventory, 1=re-inventory), whereas the second figure refers to the plot number. Black symbols represent fenced plots.

only on the fenced plots in 1998. New species/groups of species on the dry heath are Hieracium spp. on open plots and Juncus trifidus and Loiseleuria procumbens on the fenced plots. Cladina rangiferina and Phyllodoce caerulea are new species on both fenced and open plots.

Arctostaphylos alpina and Juncus trifidus were found on the open plots in the Långfjället dry heath in 1995, but not in 1998. Festuca ovina, Andromeda polifolia and Trientalis europaea were absent from the open plots in 1995, but had anrived by the time of the re-inventory in 1998. Juncus trifidus was a new species on the fenced plots in 1998.

On the Fulufjäll dry heath, Stereocaulon paschale was found only on the open plots in 1995. Trientalis europaea was found on the fenced plots in 1996, but not in 1999, whereas that species had arrived on the open plots at reinventory. Arctostaphylos alpina is another species found on the open plots in 1999, having been absent in 1996 . Nardus stricta was found neither on the fenced nor on the open plots in 1995/96, but was found on the fenced plots at re-inventory.

\section{Shannon's diversity index}

Table 14 shows species diversity for the fenced and open plots, calculated according to formula 1. In Tavvavuoma's birch forest-heath type with mosses, diversity increased

Table 14. Shannon's diversity index for fenced and open plots in the moss-rich birch forest and the dry dwarf-shrub heath at Tavvavuoma, Sonfjället, Långfjället and Fulufjället. In each vegetation type and at each site three fenced and three open plots were studied, each with an area of $22 \mathrm{~m} \times 22 \mathrm{~m}$.

\begin{tabular}{llclll}
\hline Vegetation type & Plots & Tavvavuoma & Sonfjället & Långfjället & Fulufjället \\
\hline Birch for. w mosses & Fenced 1995 & 1.867 & $2.399^{1)}$ & 2.715 & $2.661^{1)}$ \\
& Fenced 1999 & 2.259 & $2.409^{2)}$ & $2.471^{2)}$ & 2.779 \\
& Open 1995 & 1.883 & 2.405 & 2.639 & 2.880 \\
& Open 1999 & 1.948 & $2.508^{2)}$ & $2.532^{2)}$ & 2.724 \\
Dry heath & Fenced 1995 & 2.291 & $1.757^{1)}$ & 2.807 & $2.423^{1)}$ \\
& Fenced 1999 & 2.894 & $2.381^{2)}$ & $2.858^{2)}$ & 2.483 \\
& Open 1995 & 2.273 & $1.718^{2)}$ & 2.625 & 2.464 \\
1) = Inventory, 1996; & Open 1999 & 2.924 & $2.311^{2)}$ & $2.866^{2)}$ & 2.575 \\
${ }^{2)}=$ Inventory, 1998. & & & & & \\
\hline
\end{tabular}


during the years, but the increase was significantly greater on the fenced plots ( $p<0.05$, Mixed-model ANOVA). On Fulufjället, diversity increased on the fenced plots, but decreased on the open plots ( $p<0.05$, Mixed-model ANOVA), and on Långfjället, species diversity generally decreased, without any differences between fenced and open plots $(p<0.001$, Mixed-model ANOVA). There were no significant differences in species richness on Sånfjället.

On the dry heath at Tavvavuoma, diversity increased somewhat between years, for both fenced and open plots $(p<0.001$, Mixed-model ANOVA). The same applies also to the study plots at Sånfjället and Långfjället $(p<0.001$ and $p<0.05$, respectively, Mixed-model ANOVA). There were no significant differences in species diversity on Fulufjället.

\section{Ordination}

The ordination diagram in Figure 4a shows that in the birch forest-heath type with mosses there is a difference in vegetation between the various sites. The plots at Tavvavuoma (lower right corner) and those at Sånfjället (upper right corner) are all assembled in relatively distinct groups. Some change, although small, can, however, be seen in the position of the individual plots between years at these sites. The sites that may be assumed to be most similar to each other floristically are Fulufjället and Långfjället, since their plots lie relatively close together in the diagram. It is also on these plots that we can see the longest movements of one and the same plot between the two inventories.

The different study sites on the dry heath (Fig. 4b) are orientated more or less in groups. One of Långfjället's open plots (plot 1), however, lies very close to the Fulufjället plots and, throughout the years, has moved even closer in the diagram. The other sites are more separated from each other. The plots at Tavvavuoma have moved diagonally downwards over the years, towards the left of the diagram. Långfjället's plots also exhibit a shift down and leftwards in the diagram, but not as large.

\section{Cover}

Figures 5 and 6 show the ground layer's percentage composition in the moss-rich birch forest and the dry dwarfshrub heath at the two inventories and at all four sites. The tables in the same figures illustrate the results of ANOVAs calculated for each site and vegetation type individually. Only the species/species groups that showed significant differences in the ANOVA, where both vegetation types were tested together, were included. The results for each vegetation type are presented separately, below.

At Tavvavouma, mosses dominate in the bottom layer, e.g. Pleurozium schreberi, Hylocomium splendens and Dicranum scoparium, whereas lichens represent only a few percent. Empetrum hermaphroditum, Vaccinium myrtillus and V. vitis-idaea are the most common forms of dwarf shrub, and Deschampsiaflexuosa is almost the only grass present. The result of the analyses of variance shows that the degree of cover of Deschampsia flexuosa, Vaccinium myrtillus and $V$. vitis-idaea changed significantly over the years, as a response to fencing. Deschampsia flexuosa decreased on both the fenced and the open plots, but the reduction was greatest on the open plots. Vaccinium myrtillus increased more on the open plots than on the fenced plots, whereas $V$. vitis-idaea increased on the fenced plots and decreased on the open plots.

Birch forest-heath type with mosses: At Sånfjället the mosses (mainly Pleurozium schreberi) and Vaccinium myrtillus occupy most of the bottom and field layers, where also Empetrum hermaphroditum occurs fairly abundantly. The commonest lichens belong to the genera Cladonial Cladina and Cetraria. The only species that shows a significant change in cover on account of fencing, is Vaccinium vitis-idaea, which decreased on the fenced plots but increased on the open plots. Deschampsia flexuosa and Empetrum hermaphroditum increased on Sånfjället, regardless of treatment, whereas the other dwarf shrubs decreased.

The bottom and field layers at Långfjället consist largely of mosses and dwarf shrubs. No species or groups of species showed any significant change in degree of cover, between fenced and open plots. The degree of cover of Deschampsiaflexuosa and Vaccinium vitis-idaea decreased on both fenced and open plots, regardless of treatment, whereas that of Vaccinium myrtillus increased.

Mosses, Empetrum hermaphroditum, Vaccinium myrtillus and Deschampsia flexuosa dominate the bottom and field layers on Fulufjället. Vaccinium vitis-idaea increased on both the open and the fenced plots, but the increase was significantly larger on the fenced plots. Cetraria also shows a positive response to treatment, with a decrease on the open plots and a small increase on the fenced plots. Deschampsia flexuosa generally decreased on Fulufjället, whereas Empetrum hermaphroditum and Vaccinium myrtillus increased their degree of cover. However, no significant difference between fenced and open plots could be identified.

Dry heath: At Tavvavuoma, Empetrum hermaphroditum dominates the field and bottom layers, together with mosses and lichens belonging to the genera Cladonial Cladina. The result of the analysis of variance shows that only the cover of Cetraria changed significantly during the years, as a response to fencing. Cetraria increased on both open and fenced plots, but the increase was larger on the latter. Vaccinium vitis-idaea and other dwarf shrubs generally increased their cover regardless of treatment, whereas that of Empetrum hermaphroditum decreased.

The ground layer on Sånfjället is taken up to $80 \%$ by the category 'other' (litter, stones, bare soil and water). The genera Cladonia/Cladina are the most common among the lichens, and Empetrum hermaphroditum is the commonest 


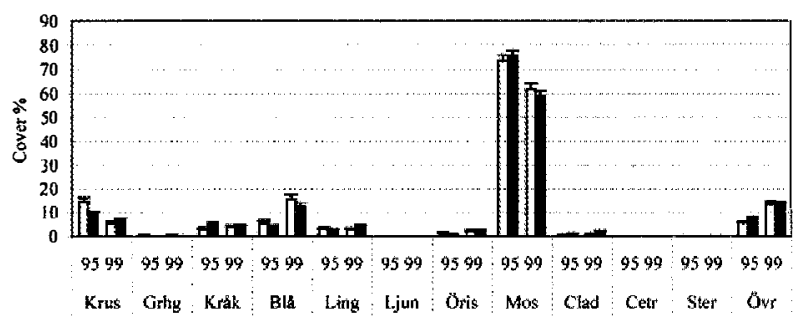

\begin{tabular}{llllllll}
\hline Factor & Df & Krus & Kråk & Blå & Ling & Öris & Cetr \\
\hline Area & 4 & $*$ & $*$ & $*$ & $*$ & $* *$ & \\
Treatment & 1 & & & & & & \\
Year & 1 & $* * *$ & & $* * *$ & $*$ & & \\
& & & & & & & \\
Year*Area & 4 & $* *$ & & $* *$ & $*$ & & $*$ \\
Year*Treatment & 1 & $* * *$ & & $* * *$ & $* * *$ & & \\
\hline
\end{tabular}

Sonfjätloe M RB

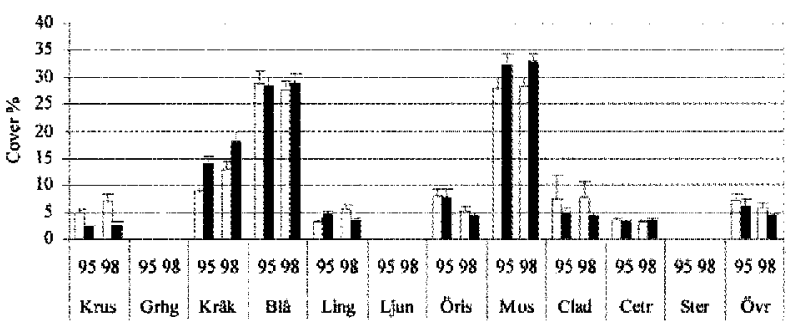

\begin{tabular}{llllllll}
\hline Factor & DI & Krus & Kråk & Blå & Ling & Öris & Cetr \\
\hline Area & 4 & $* * *$ & $* * *$ & $* * *$ & $* * *$ & & $* * *$ \\
Treatment & 1 & & & & & & \\
Year & 1 & $*$ & $* *$ & $*$ & & $*$ & \\
& & & & & & & \\
Year*Area & 4 & & & & $*$ & & $* *$ \\
Year*Treatment & 1 & & & & $* * *$ & & \\
\hline
\end{tabular}

Langfijltet MRB

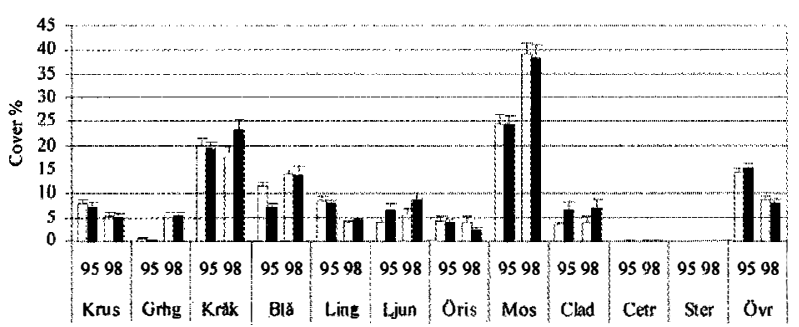

\begin{tabular}{lllllllll}
\hline Factor & Df & Krus & Krák & Bla & Ling & Oris & Cetr \\
\hline Area & 4 & & $* * *$ & & $* * *$ & & $*$ \\
Treatment & 1 & $* *$ & & $* *$ & & & \\
Year & 1 & $* * *$ & $*$ & $* * *$ & $* * *$ & & \\
& & & & & & & \\
Year*Area & 4 & & & & & $*$ & \\
Year*Treatment & 1 & & & & $*$ & & $*$ \\
\hline
\end{tabular}

Fuluf̧axlles MRB

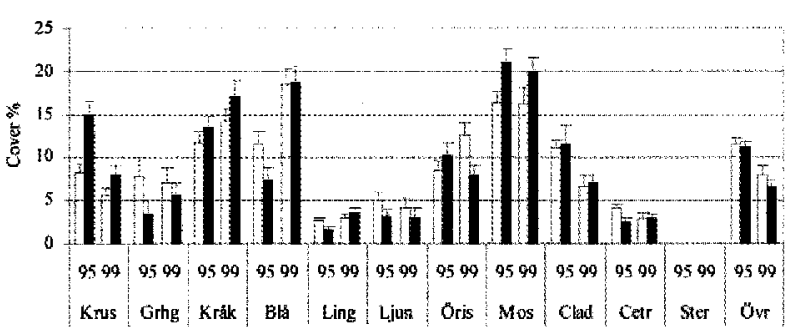

\begin{tabular}{llllllll}
\hline Factor & Df & Krus & Krak & Blå & Ling & Oris & Cetr \\
\hline Area & 4 & $* * *$ & $* * *$ & $* * *$ & $*$ & $* * *$ & \\
$\begin{array}{l}\text { Treatment } \\
\text { Year }\end{array}$ & 1 & & & & & & \\
& 1 & $* *$ & & $* *$ & $* * *$ & & \\
Year*Area & 4 & & $* *$ & & & & $* *$ \\
Year*Treatment & 1 & & & & & &
\end{tabular}

Fig. 5. Cover \% of species and groups of species in the moss-rich birch forest on the two inventory occasions at Tavvavuoma, Sonfjället, Långfjället and Fulufjället. Black columns show fenced plots, white columns show open plots, and the error columns show the standard error (SE). The tables show the result of the ANOVA calculated individually on each site. Significance is given with $*$ for $p<0.05, * *$ for $p<0.01$ and $* * *$ for $p<0.001$. Where nothing is given, the result is not significant. Note that the scales on the $y$-axes differ between diagrammes. Abbreviations refer to: Krus. = Deschampsiaflexuosa, Grhg = Other grasses, Kråk = Empetrum hermaphroditum, Blå = Vaccinium myrtillus, Ling = Vaccinum vitis-idaea, Ljun Calluna vulgaris, Öris = Other dwarf-shrubs, Mos =Mosses, Clad. = Cladonia spp., Cetr. = Cetraria spp., Ster. = Sterocaulon paschale, and Övr = Other plants.

dwarf shrub. Cetraria spp. increased significantly more in degree of cover on the open plots than on the fenced plots, whereas Vaccinium vitis-idaea increased more on the fenced plots. Both Deschampsiaflexuosa and Vaccinium myrtillus show a general increase in degree of cover, regardless of fencing.
Empetrum hermaphroditum and Cladonia/Cladina together make up about $50 \%$ of the ground cover on Långfjället. Calluna vulgaris, other dwarf shrubs and mosses are also relatively abundant. Other dwarf shrubs show no change in cover on open plots, but increased on the fenced plots; the increase was significant. Regardless of 


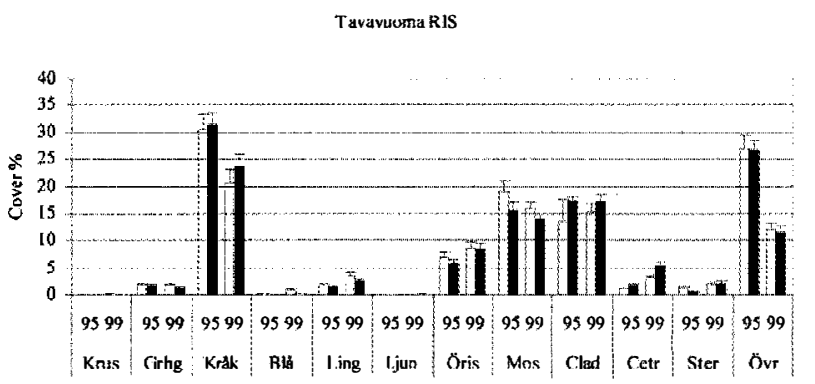

\begin{tabular}{llllllll}
\hline Factor & Df & Krus & Kråk & Blå & Ling & Öris & Cetr \\
\hline Area & 4 & & $* * *$ & & $*$ & $* * *$ & $* * *$ \\
Treatment & 1 & & & & & & \\
Year & 1 & & $* *$ & & $* * *$ & $*$ & $* * *$ \\
& & & & & & & \\
Year*Area & 4 & & & & & & $*$ \\
Year*Treatment & 1 & & & & & & $* *$ \\
\hline
\end{tabular}

Sorfälllet RIS

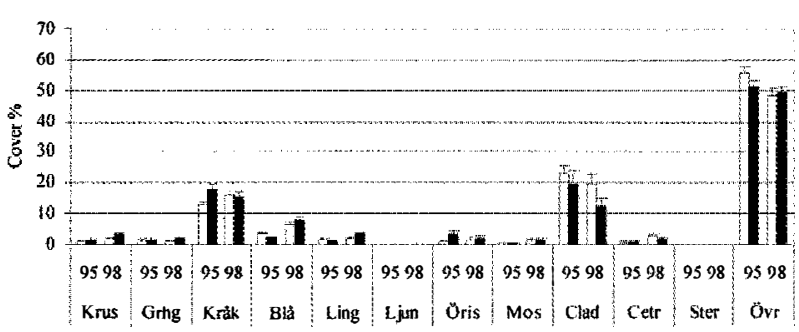

\begin{tabular}{llllllll}
\hline Factor & Df & Krus & Kråk & Blă & Ling & Oris & Cetr \\
\hline Area & 4 & $* * *$ & $*$ & $* * *$ & $* * *$ & $* * *$ & $* * *$ \\
Treatment & 1 & & & & & & \\
Year & 1 & $* * *$ & & $* * *$ & $* *$ & & $* * *$ \\
& & & & & & & \\
Year*Arca & 4 & $*$ & $*$ & $*$ & & & $* * *$ \\
Year*Treatment & 1 & & & & $*$ & & $* * *$ \\
\hline
\end{tabular}

Långfiăllet RIS

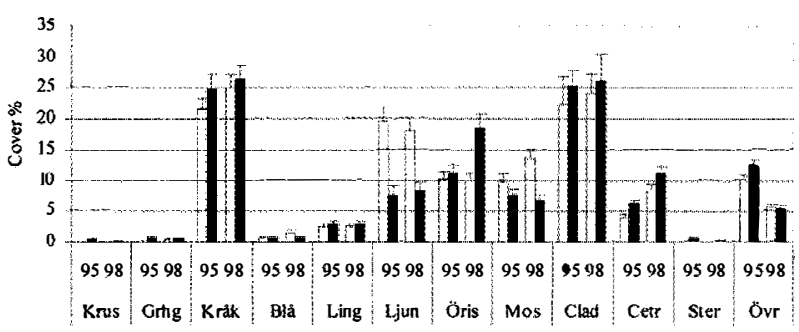

\begin{tabular}{llllllll}
\hline Factor & Df & Krus & Kråk & Blå & Ling & Öris & Cer \\
\hline Area & 4 & $* * *$ & $* * *$ & $* * *$ & $* * *$ & $* * *$ & $* * *$ \\
Treatment & 1 & & & & & & \\
Year & 1 & $* *$ & & $* *$ & & $*$ & $* * *$ \\
& & & & & & & \\
Ycar*Arca & 4 & $*$ & & $*$ & & & \\
Year*Treatment & 1 & & & & & $*$ & \\
\hline
\end{tabular}

Fuluffället RIS

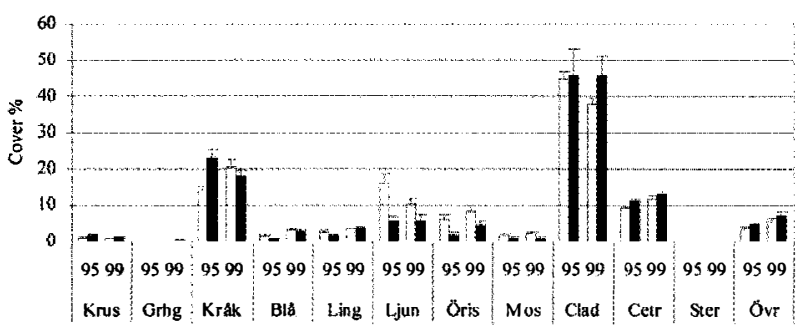

\begin{tabular}{|c|c|c|c|c|c|c|c|}
\hline Factor & Df & Krus & Kråk & Blå & Ling & Öris & Cctr \\
\hline Area & 4 & $* * *$ & $*$ & $* * *$ & $* * *$ & $* * *$ & \\
\hline Treatment & 1 & & & & & & \\
\hline Year & $\xi$ & & & & $* * *$ & & $* *$ \\
\hline $\begin{array}{l}\text { Year*Ared } \\
\text { Year*Treatment }\end{array}$ & $\begin{array}{l}4 \\
1\end{array}$ & $* *$ & $* *$ & $* *$ & & & $*$ \\
\hline
\end{tabular}

Fig. 6. Cover \% of species and groups of species in the dry heath at the two inventories at Tavvavuoma, Sånfjället, Långfjället and Fulufjället. Black columns show fenced plots, white columns show open plots, and the error columns show the standard error (SE). The tables show the result of the ANOVA calculated individually on each site. For explanations see Fig. 5.

treatment, Cetraria spp. and Vaccinium myrtillus increased, whereas Deschampsia flexuosa decreased.

Most of the ground layer on Fulufjället is occupied by lichens belonging to the genera Cladonia/Cladina, followed by Empetrum hermaphroditum as the dominating dwarf shrub. Vaccinium vitis-idaea increased on both fenced and open plots, but the increase was significantly larger on the fenced plots. Between the two inventories, Empetrum hermaphroditum increased its cover on the open plots, and decreased on the fenced plots. No other species or species group shows similar significant differences between fenced and open plots. Cetraria spp. has increased on both open and fenced plots. 
Tavvavtoma MRB

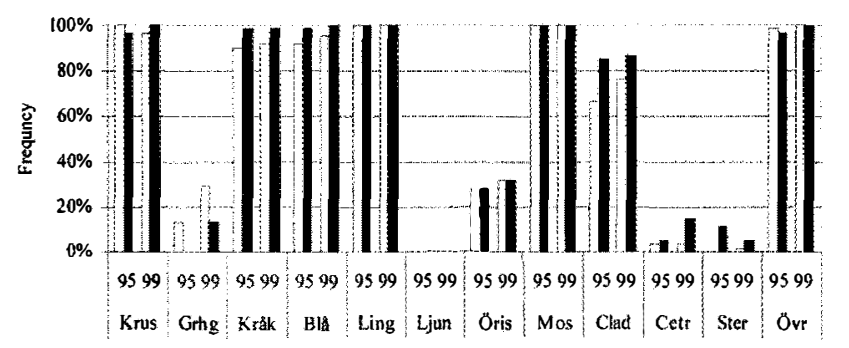

\begin{tabular}{lll}
\hline Factor & Df & Clad \\
\hline Area & 1 & \\
Treatment & 1 & $*$ \\
Year & 1 & $*$ \\
& & \\
Year*Area & 1 & $*$ \\
Year*Treatment & 1 & \\
\hline
\end{tabular}

Sonfjallet MRB

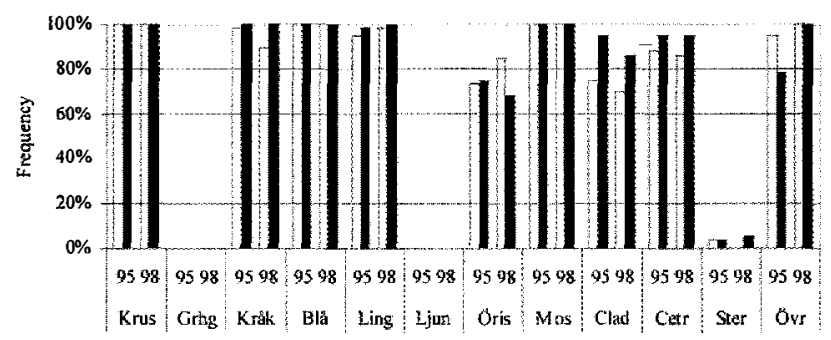

Lảngtjälet MRB

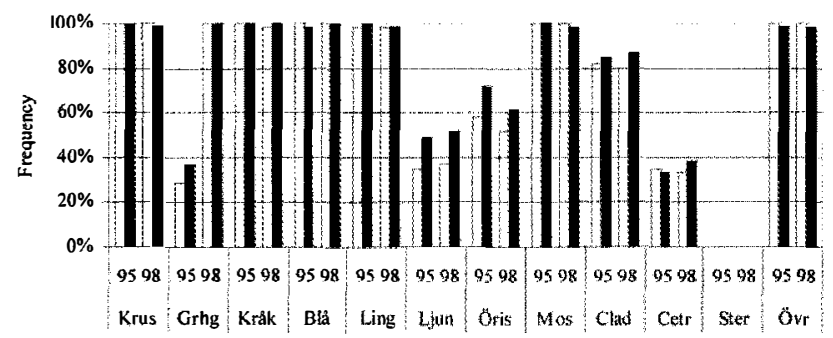

\begin{tabular}{llll}
\hline Factor & Df & Ljun & Öris \\
\hline Area & 1 & & $*$ \\
Treatment & 1 & & \\
Year & 1 & $*$ & \\
& & & \\
Year*Area & 1 & $*$ & $*$ \\
Year*Treatment & 1 & $*$ & $* *$ \\
\hline
\end{tabular}

Fulufjället MRB

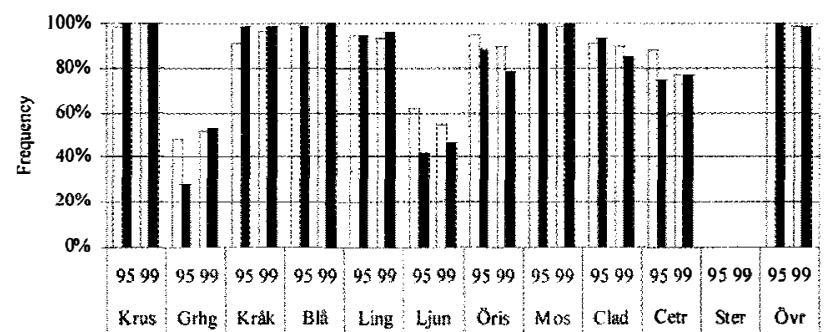

\begin{tabular}{llll}
\hline Factor & Df & Ljun & Öris \\
\hline Area & 1 & & \\
Treatment & 1 & & \\
Year & 1 & $*$ & \\
& & & \\
Year*Area & 1 & $*$ & \\
Year*Treatment & 1 & $* *$ & $*$ \\
\hline
\end{tabular}

Fig. 7. The percentage of plots with occurrence of a species/species group in the moss-rich birch forest at the two inventories at Tavvavuoma, Sånfjället, Långfjället and Fulufjället. Black columns show fenced plots, white columns show open plots, and the error columns show the standard error (SE). The tables show the results of the logistic regression calculated individually on each site. For explanations see Fig. 5.

\section{Frequency}

Figures 7 and 8 show the number of plots with presence of a species/species group in the moss-rich birch forest and the dry dwarf-shrub heath, respectively, at the two inventories and on all four sites. The tables in the same figures illustrate the results of the logistic regression calculated for each site and vegetation type individually. Only the spe- cies/species groups that showed significant differences in frequency between years, as a response to fencing or both, are included in the tables. The results for each vegetation types are presented separately below.

Birch forest-heath type with mosses: No large changes occurred in the frequency of species/species groups in the plots. At only two sites, Långfjället and Fulufjället, were significant differences found as a response to fencing. At 

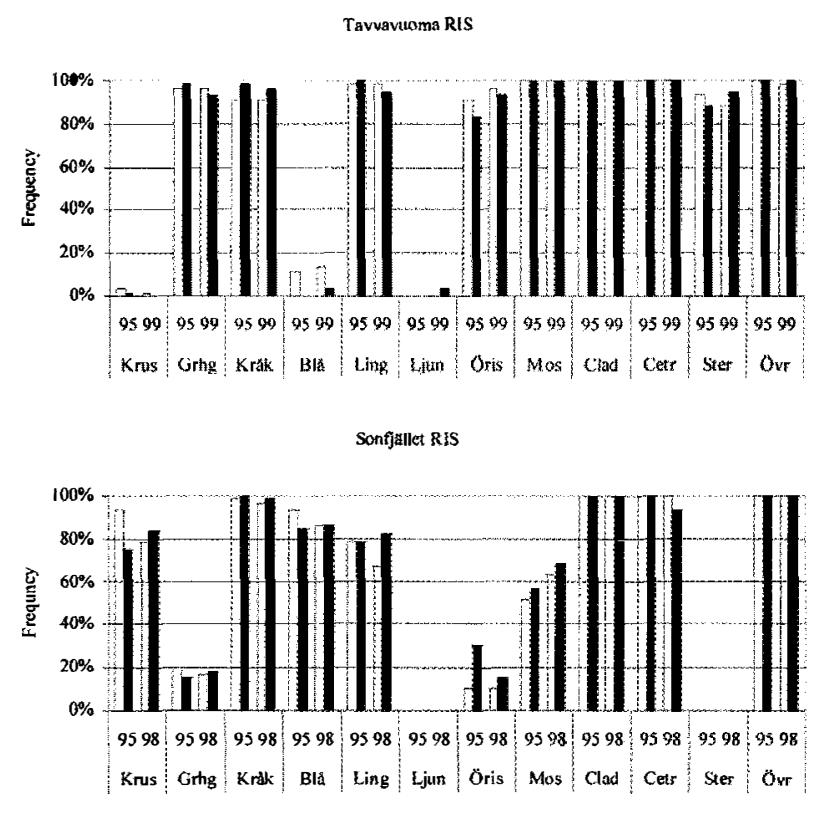

\begin{tabular}{lllll}
\hline Faclur & Df & Krus & Ling & Öris \\
\hline Area & 1 & & & $*$ \\
Treatment & 1 & $*$ & & $*$ \\
Year & 1 & $* *$ & $* * *$ & $*$ \\
& & & & \\
Year*Area & 1 & & $* *$ & $*$ \\
Year*Treatment & 1 & $*$ & $*$ & \\
\hline
\end{tabular}

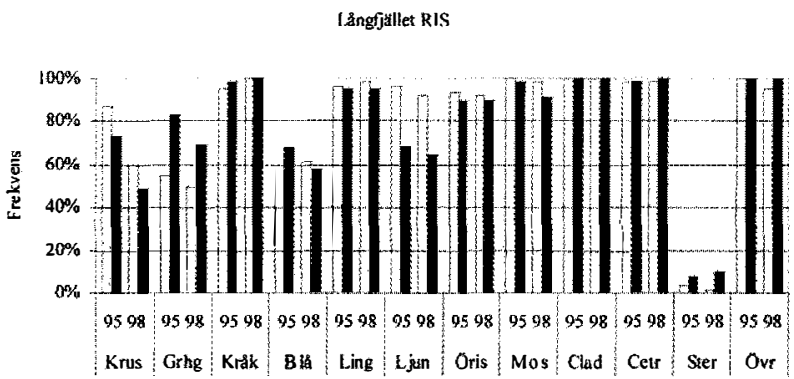

\begin{tabular}{lll}
\hline Factor & Df & Blå \\
\hline Area & 1 & \\
Treatment & 1 & \\
Year & 1 & $* *$ \\
& & \\
Year*Area & 1 & $* *$ \\
Year*Treatment & 1 & $* * *$ \\
\hline
\end{tabular}

Fulutjaller RIS

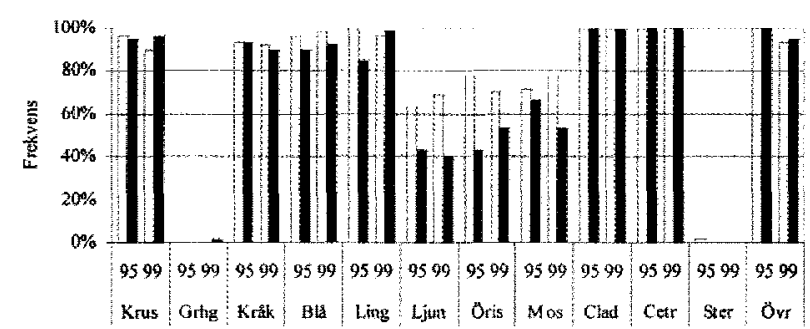

\begin{tabular}{llll}
\hline Factor & Df & Krus & Ljun \\
\hline Area & 1 & & \\
Treatment & 1 & & $*$ \\
Year & 1 & $*$ & \\
& & & \\
Year*Area & 1 & & \\
Year*Treatment & 1 & & $* *$ \\
\hline
\end{tabular}

Fig. 8. The percentage of plots with occurrence of a species/species group in the dry dwarf-shrub heath on the two inventory occasions at Tavvavuoma, Sonfjället, Långfjället and Fulufjället. Black columns show fenced plots, white columns show open plots, and the error columns show the standard error (SE). The tables show the result of the logistic regression calculated individually on each site. For explanations see Fig. 5.

Långfjället, Calluna vulgaris had become more frequent in general, but the increase was greater on the fenced plots. Other dwarf shrubs, on the other hand, decreased in frequency on both the open and the fenced plots; the decrease was significantly greater on the latter. The same applies to 'other dwarf shrubs' on Fulufjället, where Calluna vulgaris decreased in frequency on the open plots, but increased on the fenced plots.

Dry heath: On Sånfjället, the frequency of Deschampsia flexuosa and Vaccinium vitis-idaea increased on the fenced plots but decreased on the open plots, whereas other dwarf shrubs showed a general decrease in occurrence, regardless of treatment. Vaccinium myrtillus increased in frequency on the open plots, but decreased on the fenced plots on Långfjället, and the same change was found for Calluna vulgaris on Fulufjället. On Fulufjället, Deschampsia flexuosa decreased significantly, regardless of treatment. 
Tavvanioma Mrb

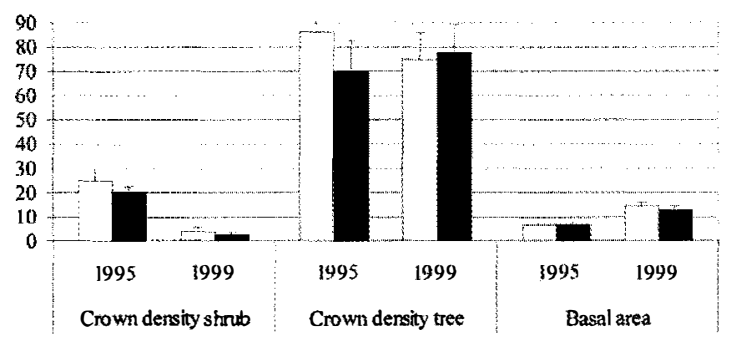

\begin{tabular}{|c|c|c|c|}
\hline Factor & Df & $\begin{array}{l}\text { Crown density } \\
\text { shrub }\end{array}$ & Basal area \\
\hline Area & 4 & & \\
\hline Ireatment & 1 & & \\
\hline Ycar & ] & **** & **** \\
\hline $\begin{array}{l}\text { Year*Area } \\
\text { Year*Treatment }\end{array}$ & $\begin{array}{l}4 \\
1\end{array}$ & & \\
\hline
\end{tabular}

Sonfjąllet Mrb

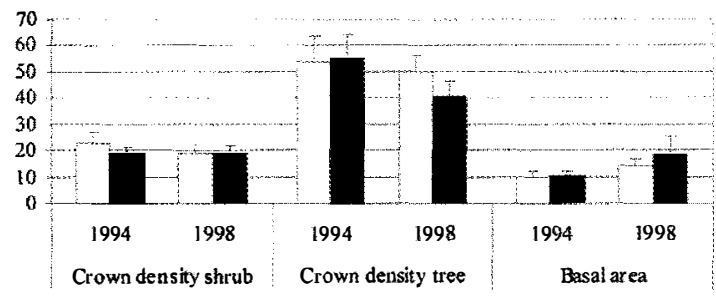

Långfjallet Mrb

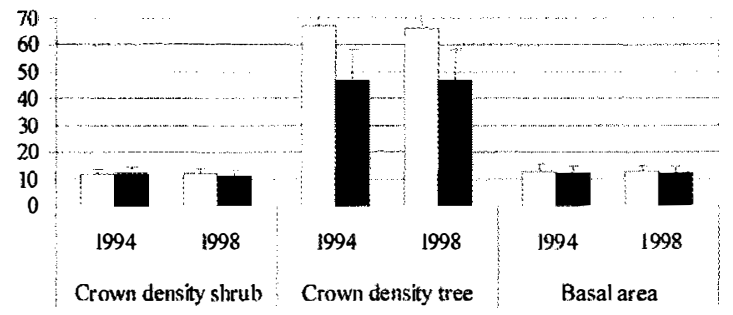

Fulufjället Mrb

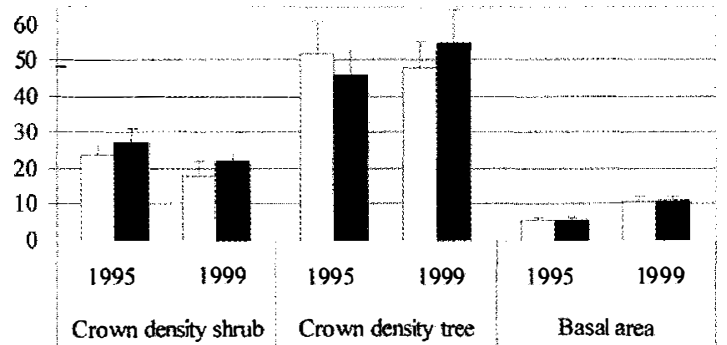

\begin{tabular}{lll}
\hline Factor & Df & Basal area \\
\hline Area & 4 & \\
Treatment & 1 & \\
Year & 1 & $* * *$ \\
& & \\
Year*Area & 4 & \\
Year* Treament & 1 & \\
\hline
\end{tabular}

Fig. 9. Crown cover,per cent, of shrubs and trees, and basal area of trees $\left(\mathrm{m}^{2} \mathrm{ha}^{-1}\right)$ at the two inventories at Tavvavuoma, Sånfjället, Långfjället and Fulufjället. Black columns show fenced plots, white columns show open plots, and the error columns show the standard error (SE). The tables show the result of the ANOVAs calculated individually on each site. For explanations see Fig. 5.

\section{Shrub- and tree-layer}

Figure 9 shows the crown cover of the shrub- and treelayer, together with tree basal area at the two inventories in the birch forest-heath type with mosses at Tavvavuoma, Sånfjället, Långfjället and Fulufjället. A significant decrease during the years in the crown cover of the shrub layer was found only at Tavvavuoma. At Tavvavouma and Fulufjället, there was also an increase in tree basal area. No significant changes, in either the crown cover of the shrub- and tree-layer or the basal area, were found at the other sites. 
Table 15. Number of reindeer droppings per hectare in fenced and open plots in the birch forest-heath type with mosses and in the dry heath at Tavvavuoma, Sånfjället, Långfjället and Fulufjället between 1994 and 1995. Values are means \pm standard deviation.

\begin{tabular}{|c|c|c|c|c|c|c|c|}
\hline \multirow[b]{2}{*}{ Site } & \multirow[b]{2}{*}{ Plots } & \multicolumn{3}{|c|}{ Birch forest-heath type with mosses } & \multicolumn{3}{|c|}{ Dry heath } \\
\hline & & Reindeer & Moose & Hare & Reindeer & Moose & Hare \\
\hline \multirow[t]{4}{*}{ Tavvavuoma } & Fenced 1995 & $129 \pm 47$ & - & - & - & - & - \\
\hline & Fenced 1999 & - & - & - & - & - & - \\
\hline & Open 1995 & $92 \pm 45$ & - & - & $3299 \pm 989$ & - & - \\
\hline & Open 1999 & - & - & - & $2167 \pm 241$ & - & - \\
\hline \multirow[t]{4}{*}{ Sånfjället } & Fenced 1994 & - & - & - & $200 \pm 101$ & - & - \\
\hline & Fenced 1998 & - & - & - & - & - & - \\
\hline & Open 1994 & - & - & - & $614 \pm 174$ & - & - \\
\hline & Open 1998 & $276 \pm 159$ & - & - & $322 \pm 257$ & - & $202 \pm 92$ \\
\hline \multirow[t]{4}{*}{ Långfjället } & Fenced 1994 & $69 \pm 42$ & $62 \pm 5$ & - & $426 \pm 39$ & - & - \\
\hline & Fenced 1998 & - & - & - & - & - & - \\
\hline & Open 1994 & $14 \pm 14$ & $7 \pm 3$ & - & $256 \pm 38$ & - & - \\
\hline & Open 1998 & - & - & - & $312 \pm 175$ & - & - \\
\hline \multirow[t]{4}{*}{ Fulufjället } & Fenced 1996 & - & $147 \pm 97$ & - & * & - & $*$ \\
\hline & Fenced 1999 & - & - & - & - & - & - \\
\hline & Open 1995 & - & - & - & $*$ & & - \\
\hline & Open 1999 & - & $18 \pm 18$ & - & - & - & - \\
\hline
\end{tabular}

\section{Droppings}

Table 15 shows the number of piles of droppings per hectare of reindeer, elk and hare for the two types of vegetation and on the study plots at all sites. In the birch forest-heath type with mosses at Tavvavuoma, reindeer droppings were found only in 1995 , when all plots were open. Droppings found on areas that were subsequently fenced had disappeared by 1999. A similar pattern was also found for Långfjället, where reindeer and elk droppings were found in 1994, but none were found at the re-inventory in 1998. On Sånfjället, reindeer droppings were found only in 1998 on the open plots. At Fulufjället, only elk droppings were found on the fenced plots in 1996, and on the open plots in 1999. No droppings of hare were found in the birch forest-heath type with mosses at any of the four study sites.

No droppings of elk or hare were found on the study plots on the dry heath at Tavvavuoma, and the amount of reindeer droppings decreased on the open plots between 1995 and 1999. The reduction by half of the reindeer droppings on the open plots on Sånfjället's dry heath corresponds with the reduction in the number of reindeer in

Table 16. Number of taxa, for fenced and open plots at Tavvavuomna in 1995 and 1999, and at Fulufjället in 1995, 1996 and 1999.

\begin{tabular}{lcc}
\hline Plots & Tavvavuoma & Fulufjället \\
\hline Fenced 1995 & 44 & $29 *$ \\
Fenced 1999 & 46 & 29 \\
Open 1995 & 50 & 30 \\
Open 1999 & 48 & 29 \\
$*$ Inventory, 1996. & & \\
\hline
\end{tabular}

the Mittådalen Saami village (Figure 3). On Långfjället, the reindeer droppings found in 1994 on the open areas that were later fenced, had disappeared by 1998 . An increase in the number of piles of reindeer droppings was noted on the open plots, but it is not possible to link this with the number of reindeer, which remained fairly constant in Idre New Saami village during the 1990s (Figure 3). The inventories on the Fulufjället dry heath in 1995/96 recorded only sporadic occurrences of reindeer and hare droppings. At the re-inventory in 1999, no droppings were found.

\subsection{Birch forest-heath type with lichens}

\section{Species present}

Two sites with the vegetation type birch forest-heath type with lichens are included in the project, Tavvavuoma and Fulufjället. Table 16 shows the number of taxa (species, species groups, genus, etc.) found at the two inventories on the two sites, and the appendix lists all taxa found. (The fact that species which are difficult to determine, e.g. juvenile lichensbelonging to the genus Cladonia, have been

Table 17. Shannon's diversity index for fenced and open plots at Tavvavuoma in 1995 and 1999, and on Fulufjället in 1995, 1996 and 1999.

\begin{tabular}{lcc}
\hline Plots & Tavvavuoma & Fulufjället \\
\hline Fenced 1995 & 2.487 & $2.145^{*}$ \\
Fenced 1999 & 2.736 & 2.238 \\
Open 1995 & 2.504 & 2.390 \\
Open 1999 & 2.642 & 2.345 \\
* Inventory, 1996. & & \\
\hline
\end{tabular}


grouped together when it was impossible to determine the species to which they belonged, makes it difficult to see from the species list whether a certain species was actually present, or if it disappeared over the years.)

At Tavvavuoma, Arctostaphylos alpina and Phleum alpinum disappeared from the open plots, whereas $A n$ tennaria dioica and Phleum alpinum disappeared from the fenced plots. Calamagrostis lapponica and Calluna vulgaris were two species that had arrived on the open plots, whereas Hieracium spp., Anthoxanthum odoratum, Juncus trifidus and Peltigera aphthosa were new species on the fenced plots.

On Fulufjället, there was no particular change in species composition between the two inventories. Polytrichum spp., however, had arrived on both the fenced and the open plots.

\section{Shannon's diversity index}

Table 17 shows the species diversity for fenced and open plots, calculated according to formula 1. At Tavvavuoma, the diversity on both the open and fenced plots increased slightly over the years $(p<0.01$, Mixed-model ANOVA). No significant differences in species richness could be found for the plots on Fulufjället.

The ordination diagram (Fig. 10) shows a separation of plots on Fulufjället from those at Tavvavuoma along the $\mathrm{x}$-axis. All plots on Fulufjället are placed to the right in the diagram, and those at Tavvavuoma to the left. Most of the plots moved downwards in the diagram over the years. Exceptions are plot 6 at Tavvavuoma and plot 6 on Fulufjället, both of which moved upwards. The diagram also shows that the shrubs are, on average, taller on Fulufjället, whereas the rees are taller at Tavvavuoma.

Fufufjallet LRB

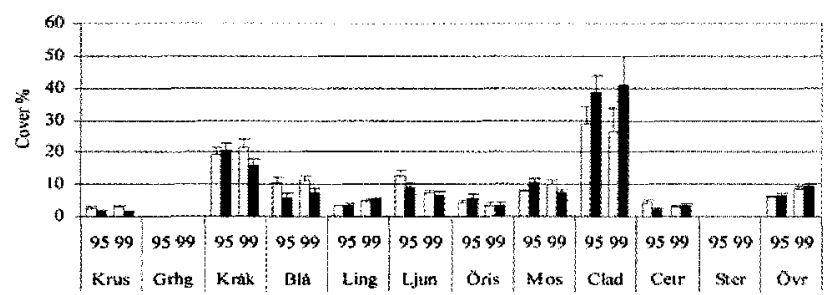

Tavavuoma LRI3

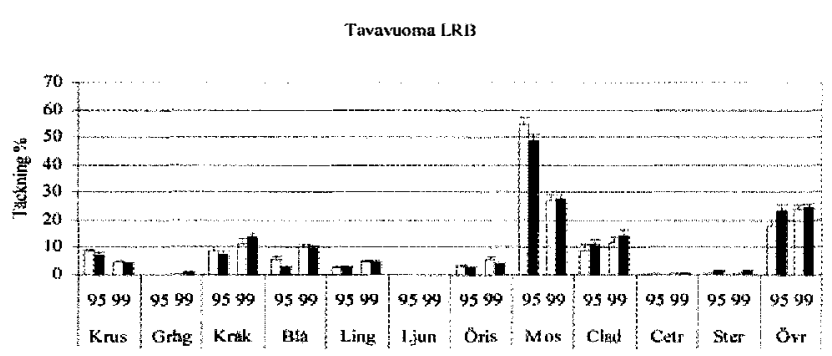

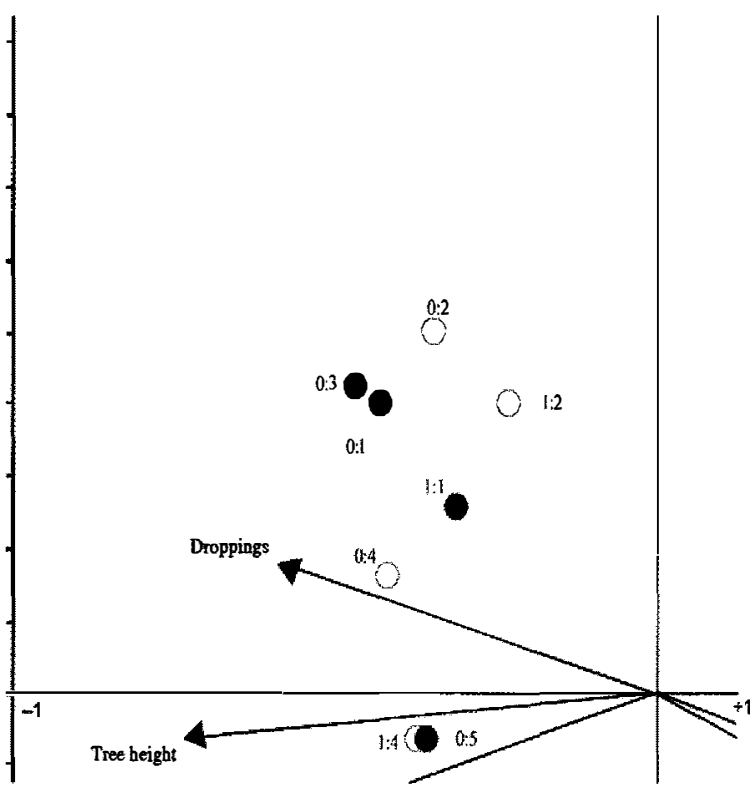

Fig. 10. Ordination diagram (PCA) for study plots in the birch forest-heath type with lichens at Tavvavuoma and on Fulufjället. The first figure in the identification code refers to the inventory ( $0=$ first inventory, $1=$ second inventory), whereas the second figure refers to the plot number. Black symbols represent fenced plots.

\section{Cover}

Figure 11 shows the percentage composition of the ground layer at the two inventories, in the birch forest-heath type with lichens at Tavvavuoma and on Fulufjället. The tables in the same figure show the results of the ANOVAs calculated individually at each site. Only the species/species groups that showed significant results in the ANOVA,

\begin{tabular}{lllllllll}
\hline Factor & Df & Krus & Blå & Ling & Ljun & Moss & Cetr & Ovr \\
\hline Area & 4 & $* *$ & $* * *$ & $* * *$ & $* *$ & $* * *$ & $* * *$ & \\
Treatment & 1 & & & & & & & \\
Year & 1 & & $*$ & $* * *$ & $* *$ & & & $*$ \\
& & & & & & & & \\
Year*Area & 4 & $*$ & & & & $*$ & $*$ & \\
Year*Treatment & 1 & & & & & 0.06 & $*$ & \\
\hline
\end{tabular}

\begin{tabular}{llllllll}
\hline Factor & Df & Krus & Gring & Blå & Ling & Moss & Orvr \\
\hline Area & 4 & & & $* * *$ & $* * *$ & & \\
Treatment & 1 & & $* *$ & & & & $*$ \\
Year & 1 & $*$ & $* *$ & $* * *$ & $* * *$ & $* * *$ & \\
Year*Area & 4 & & & & $* *$ & & \\
Year*Treatment & 1 & & & & & & \\
\hline
\end{tabular}

Fig. 11. Cover, per cent, of species and species groups at the two inventories in the birch forest-heath type with lichens at Tavvavuoma and on Fulufjället. Black columns show fenced plots, white columns show open plots and the error columns give the standard error (SE). The tables show the results of ANOVAs calculated individually for each site. Abbreviations, see Figure 5. 
where both sites were tested, have been included.

Mosses dominatestrongly at Tavvavuoma, whereas the most common lichens are represented by species belonging to Cladonia/Cladina. The result of the analyses of variance show that no species/species group had changed significantly in degree of cover as a response to fencing. Other grasses/sedges, Vaccinium myrtillus and V. vitisidaea increased in general at Tavvavuoma, whereas Deschampsiaflexuosa and mosses decreased. Mosses represent the largest decrease in cover degree; they decreased from 1995 to 1999 from about $50 \%$ to slightly less than $30 \%$. The reduction is of approximately the same magnitude for both fenced and open plots.

The largest proportion of the ground layer in the Fulufjället birch forest-heath type with lichens consists of lichens belonging to the genera Cladonia/Cladina, followed by Empetrum hermaphroditum, which is the dominating dwarf shrub. Between the two inventories, Cetraria spp. increased its degree of cover on fenced plots, and decreased on open plots. No other species or species group shows similar significant differences between fenced and open plots. Vaccinium myrtillus, V. vitis-idaea and 'other' increased on both the open and the fenced plots, regardless of treatment, whereas Calluna vulgaris decreased.

\section{Frequency}

Figure 12 shows the number of plots with occurrence of a species/species group at both sites at the two inventories.
Table 18. Number of reindeer droppings per hectare on fenced and open plots in Tavvavuoma's Birch forest-heath type with lichens in 1995 and 1999.

\begin{tabular}{lc}
\hline Plots & Dropping piles \\
\hline Fenced 1995 & $331 \pm 125$ \\
Fenced 1999 & 0 \\
Open 1995 & $275 \pm 90$ \\
Open 1999 & $643 \pm 210$ \\
\hline
\end{tabular}

The tables in the same figures show the results of the logistic regression calculated individually for each site. Only the species group (other dwarf shrubs) that showed significant differences in frequency between years, as a response to fencing or both, are included in the tables. No species or species group showed any significant change in frequency in response to fencing, neither on Fulufjället nor at Tavvavuoma, but 'other dwarf shrubs' were less frequent on Fulufjället, regardless of treatment.

\section{Shrub- and tree-layer}

Figure 13 shows the crown cover of the shrub- and treelayer and tree basal area $\left(\mathrm{m}^{2} \mathrm{ha}^{-1}\right)$ at the two inventories in the Birch forest-heath type with lichens at Tavvavuoma and Fulufjället. At both places, the crown cover in the shrub layer increased on the open plots, but decreased on the fenced plots, and the difference is significant.

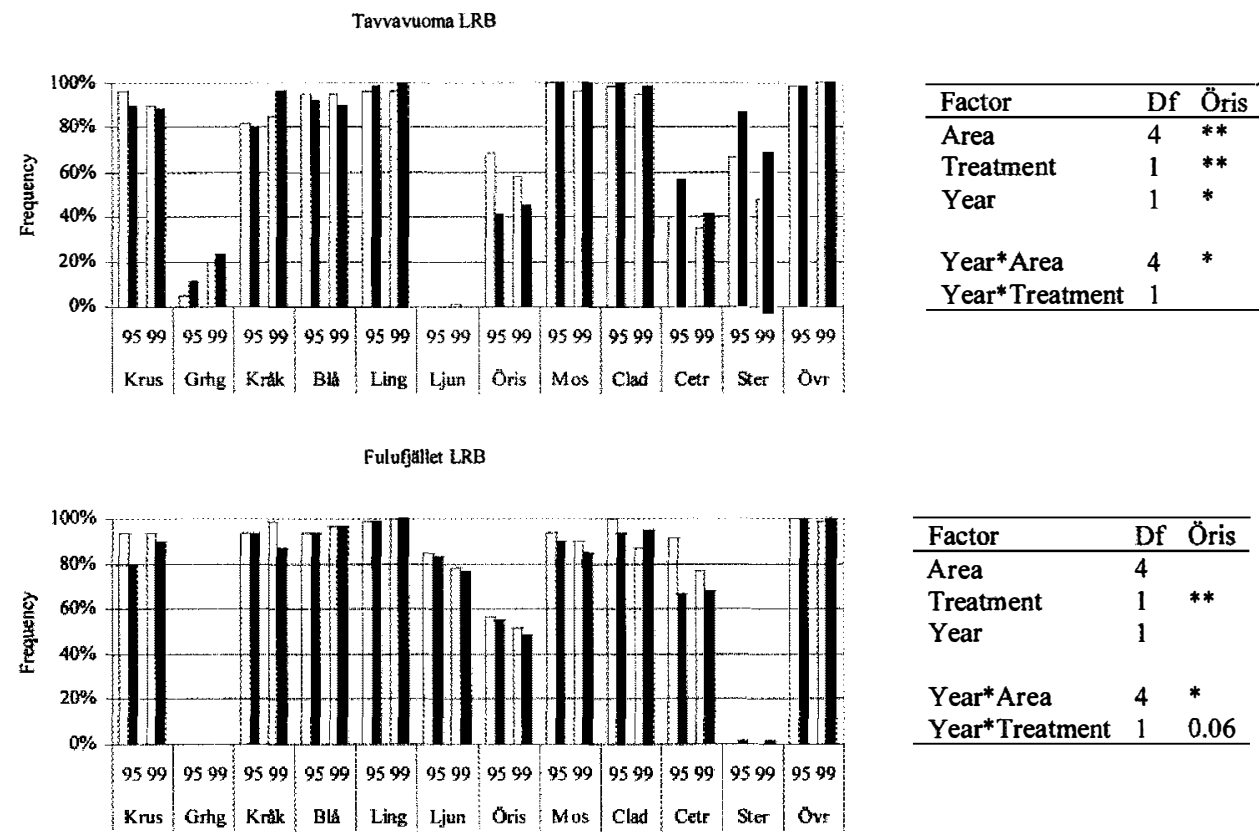

Fig. 12. Number of plots with occurrence of a species or species group at the two inventories in the birch forest-heath type with lichens. Black columns show fenced plots, white columns show open plots and the error columns give the standard error (SE). The tables show the results of logistic regressions calculated individually on each site. Abbreviations, see Figure 5. 


\section{Droppings}

No droppings of reindeer, elk or hare were noted in the study plots on Fulufjället. At Tavvavuoma, only reindeer droppings were found (Table 18). At the inventory in 1995, all plots were open and the reindeer droppings found on the plot subsequently fenced had disappeared by 1999 .

Långfjället's dry grass heath and Ritsem's dry dwarfshrub heath and low herb meadow:

The vegetation types low herb meadow and grass heath are each found only at one place, Ritsem and Långfjället, respectively, and have been treated separately. As mentioned above, the dry dwarf-shrub heath at Ritsem has also been treated separately.

\subsection{Ritsem meadow with low herbs and dry heath}

\section{Species present}

Table 19 shows the number of taxa (species, species groups, genus, etc.) found at the two inventories on the different sites and vegetation types, and all taxa are listed in the Appendix.

Pleurozium schreberi and Festuca ovina were found on the open plots on Långfjället's grass heath in 1995, but not at the inventory in 1998. The same applies to
Table 19. Number of taxa for fenced and open plots at Ritsem (dry heath and low herb meadow) and on the Långfjället grass heath.

\begin{tabular}{lccc}
\hline Plots & $\begin{array}{c}\text { Långf jället } \\
\text { grass heath }\end{array}$ & $\begin{array}{c}\text { Ritsem } \\
\text { low herb meadow }\end{array}$ & $\begin{array}{c}\text { Ritsem } \\
\text { dry heath }\end{array}$ \\
\hline Fenced 1995 & $31^{2}$ & $110^{1)}$ & 57 \\
Fenced 1997 & $35^{2)}$ & $124^{1)}$ & 64 \\
Open 1995 & $34^{2)}$ & $113^{1)}$ & 66 \\
Open 1997 & $39^{2)}$ & $118^{1)}$ & 72 \\
& & & \\
1) Inventory, 1999; & & & \\
2) Inventory, 1998. & & & \\
\hline
\end{tabular}

Stereocaulon paschale and Festuca ovina on the fenced plots. Loiseleuria procumbens and Sphagnum were not found at all in 1995, but in 1998 Sphagnum was found on both fenced and open plots, whereas Loiseleuria procumbens was found only on fenced plots.

The meadow with low herbs at Ritsem is the vegetation type with by far the largest number, and turnover, of taxa. Saxifraga cernua, Lychnis viscaria, Trientalis europaea, Botrychium lunaria, Nephroma arcticum and Salix glauca are examples of species found on the open plots in 1995, but which had disappeared in 1999. For fenced plots, Phyllodoce caerulea, Cassiope hypnoides and Trientalis europaea had disappeared over the years.

Tavvavuoma Lrb

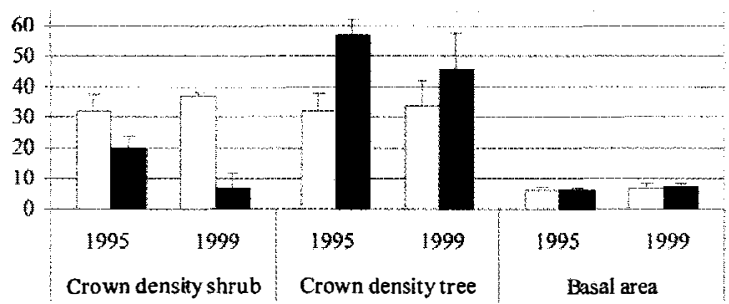

\begin{tabular}{lll}
\hline Factor & Df & Crown dens. shrub \\
\hline Area & 4 & $* * *$ \\
Treatment & 1 & \\
Year & 1 & $* * *$ \\
& & \\
Year*Area & 4 & $* * *$ \\
Year*Treatment & 1 & $*$ \\
\hline
\end{tabular}

Fulufjället Lrb

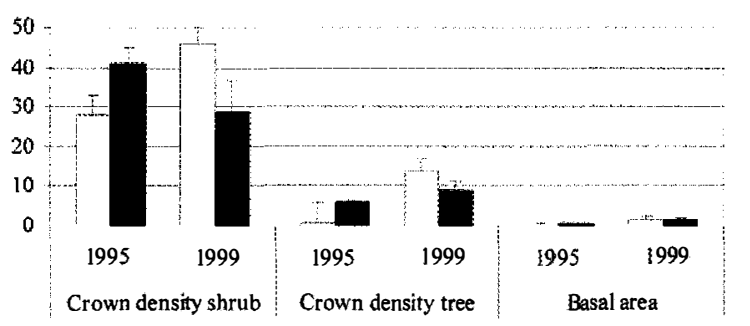

\begin{tabular}{lll}
\hline Factor & Df & Crown dens. shrub \\
\hline Area & 4 & $* *$ \\
Treatment & 1 & \\
Year & 1 & \\
& & \\
Year*Area & 4 & \\
Year*Treatment & 1 & $* *$ \\
\hline
\end{tabular}

Fig. 13. Crown cover, per cent, of shrubs and trees, together with basal area $\left(\mathrm{m}^{2} \mathrm{ha}^{-1}\right)$ of trees at the two inventories in the Birch forestheath type with lichens at Tavvavuoma and on Fulufjället. Black columns show fenced plots, white columns show open plots and the error columns give the standard error (SE). The tables show the results of ANOVAs conducted on each site individually. Abbreviations, see Figure 5. 
Examples of species that have arrived are Rhodiola rosea, Eriophorum scheuchzeri, Saxifraga foliolosa and Cladina rangiferina on the open plots, and Triglochin palustris, Eriophorum scheuchzeri and Saxifraga oppositifolia on the fenced plots.

Having been absent from the dry heath at Ritsem in 1995, Trisetum spicatum, Vaccinium uliginosum, Hylocomium splendens, Sphagnum spp. and Peltigera aphthosa were found on both fenced and open plots at the inventory in 1997. Rumex acetosa ssp. lapponicus and Gentiana nivalis, on the other hand, were found only in 1995, the latter only on open plots.

\section{Shannon's diversity index}

Table 20 shows the species diversity for fenced and open plots, calculated according to formula 1. On Långfjället's grass heath, diversity increased slightly on fenced plots, but decreased on open plots; the difference was significant $(p<0.001$, Mixed-model ANOVA). At Ritsem, there were no significant differences in species richness between fenced and open plots, but diversity had decreased in general on the dry heath $(p<0.001$, Mixed-model ANOVA).

\section{Ordination}

The result of the ordination shows that all plots on Långfjället's grass heath (Fig. 14a) have moved downwards in the ordination diagram. Additionally, at both inventories, plots 1, 5 and 6 grouped themselves together, which suggests some floristic similarity between the plots, and that changes in the vegetation have been fairly similar. Plots that diverge most from the others are plots 3 and 4 .

It is not possible to identify clearly from the diagram in Fig. 14b any definite pattern for the study plots on the meadow with low herbs at Ritsem. On Ritsem's dry heath (Fig. 14c), the open plot 2 and the fenced plot 5 have approached each other, and the same applies to the two fenced plots 1 and 3. The movements have not gone in the same direction, which indicates that there have been different changes in the composition of the vegetation on these plots.

Fig. 14. Ordination diagram (PCA) for study plots on: a) Långfjället's dry grass heath, b) Ritsem's low herb meadow, and c) Ritsem's dwarf-shrub heath. The first figure in the plot identification code refers to the inventory $(0=$ first inventory, $1=$ second inventory), whereas the second figure refers to the plot number. Black symbols represent fenced plots.
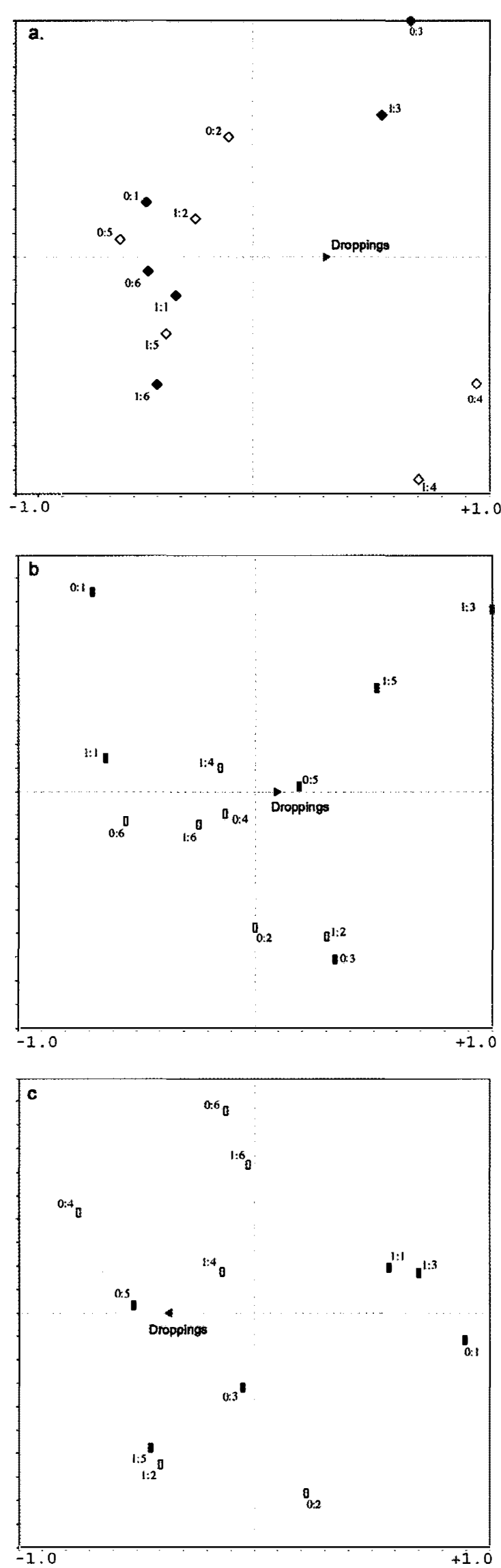
Table 20. Shannon's diversity index for fenced and open plots at Ritsem (dry heath and meadow with low herbs) and on Långfjället's grass heath

\begin{tabular}{lccc}
\hline Plots & $\begin{array}{c}\text { Långfjället } \\
\text { grass heath }\end{array}$ & $\begin{array}{c}\text { Ritsem low } \\
\text { herb meadow }\end{array}$ & $\begin{array}{c}\text { Ritsem } \\
\text { dry heath }\end{array}$ \\
\hline Fenced 1995 & $2.671^{2}$ & 3.346 & 2.775 \\
Fenced 1997 & $2.682^{2)}$ & $3.484^{1)}$ & 2.467 \\
Open 1995 & $2.855^{2}$ & $3.457^{1)}$ & 2.824 \\
Open 1997 & $2.485^{2)}$ & $3.524^{1)}$ & 2.674 \\
& & & \\
1) Inventory, 1999; & & & \\
2) Inventory, 1998. & & & \\
\hline
\end{tabular}

\section{Cover degree}

Figure 15 shows the ground layer's percentage composition of the three types of vegetation at the two inventories. The tables in the same figure show the results of the ANOVAs calculated for each individual site and vegetation type.
Only the species/species groups that showed significant differences are shown in the tables.

On Långfjället's grass heath, Deschampsia flexuosa and Cladonia/Cladina show significant signs that they thrive better on the fenced plots. Although D. flexuosa decreased on both open and fenced plots, the decrease is less pronounced on the fenced plots. Cladonia/Cladina decreased on open plots, but increased on fenced plots. Further significant differences are that the group 'other' (litter, stones, bare soil, and water) decreased on the fenced plots, but remained fairly constant on the open plots. Empetrum hermaphroditum, Vaccinium vitis-idaea and Cetraria all increased their degree of cover on the grass heath, regardless of fencing.

On the meadow with low herbs at Ritsem, grass and sedges together make up about $40 \%$ of the ground layer, herbs about $20 \%$ and mosses a few per cent less. Lichens occur only sporadically, whereas dwarf shrubs such as Vaccinium myrtillus and Calluna vulgaris are completely absent. Other herbs appear to have been favoured by grazing, as they increased on the open plots but decreased
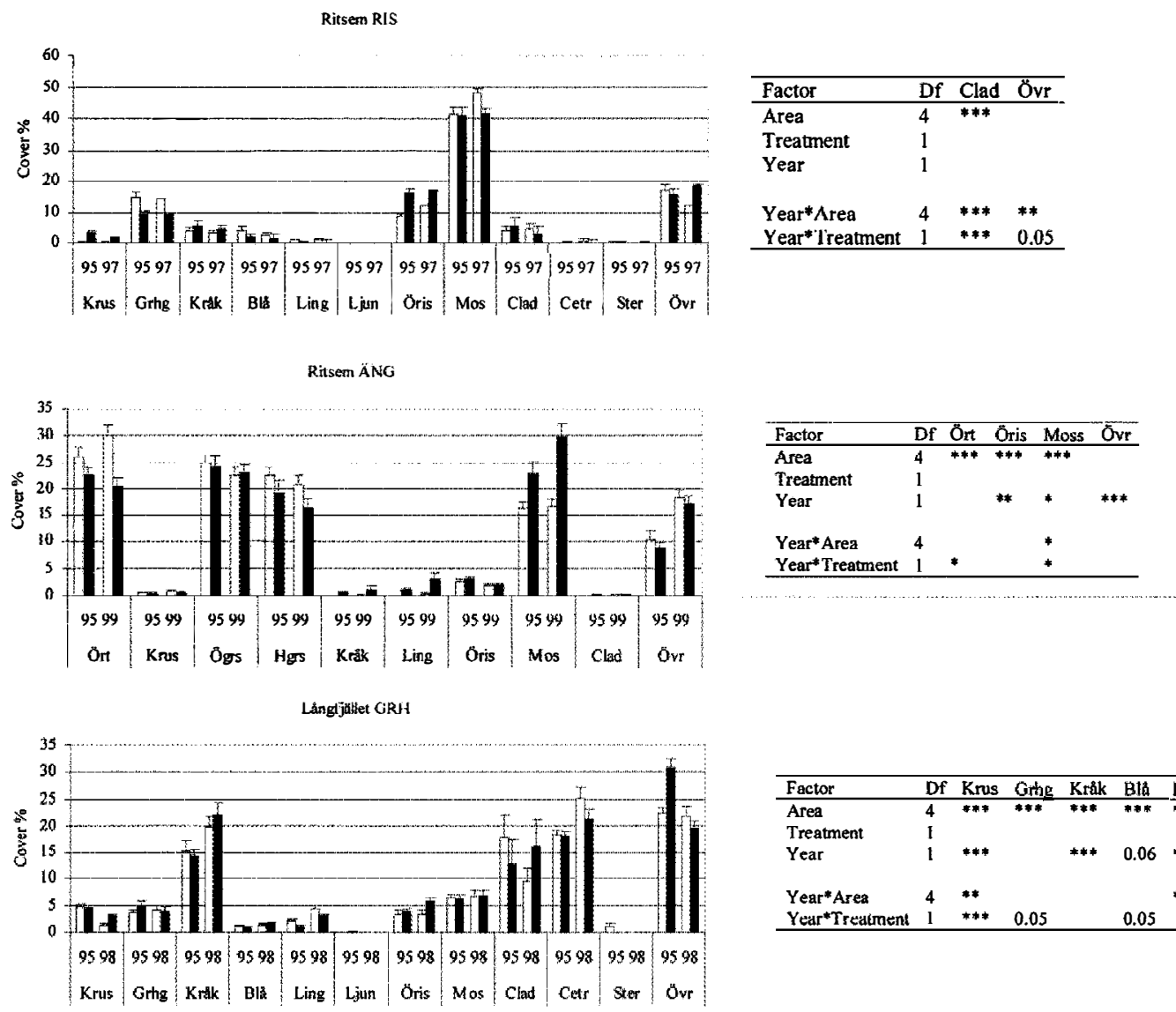

\begin{tabular}{|c|c|c|c|c|c|c|c|c|c|}
\hline Factor & Df & Krus & Grage & Kråk & Bla & Ling & Clad & Cotr & $\ddot{\phi v}$ \\
\hline Area & 4 & **** & $* * *$ & $* * *$ & 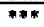 & iक & क*** & $7 * m$ & \\
\hline Treatment & I & & & & & & & & \\
\hline Year & 1 & **** & & *** & 0.06 & $* * *$ & * & * & $* * *$ \\
\hline Year*Area & 4 & $* *$ & & & & $* * *$ & **** & **** & \\
\hline Year* Treatment & 1 & *\#* & 0.05 & & 0.05 & & $* * *$ & & +44 \\
\hline
\end{tabular}

Fig. 15. Cover, per cent, of species and species groups at the two inventories on Långfjället's grass heath and at Ritsem (dry heath and meadow with low herbs). Black columns show fenced plots, white columns show open plots and the error columns give the standard error (SE). The tables show the results of ANOVAs conducted at each site individually. Abbreviations, see Fig. 5. 


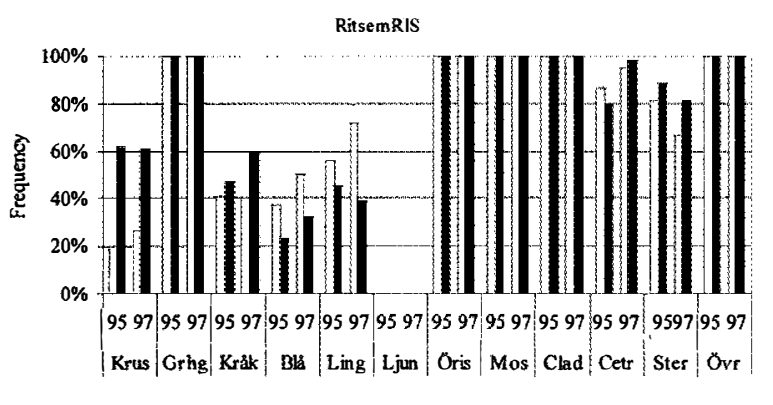

\begin{tabular}{lllll}
\hline Factor & Df & Krus & Kråk & Ling \\
\hline Area & 4 & & $* *$ & $* * *$ \\
Treatment & 1 & $* * *$ & & \\
Year & 1 & $*$ & $* *$ & $* *$ \\
& & & & \\
Year*Area & 4 & $*$ & $* * *$ & $*$ \\
Year*Treatment & 1 & $* *$ & $* *$ & $* * *$ \\
\hline
\end{tabular}

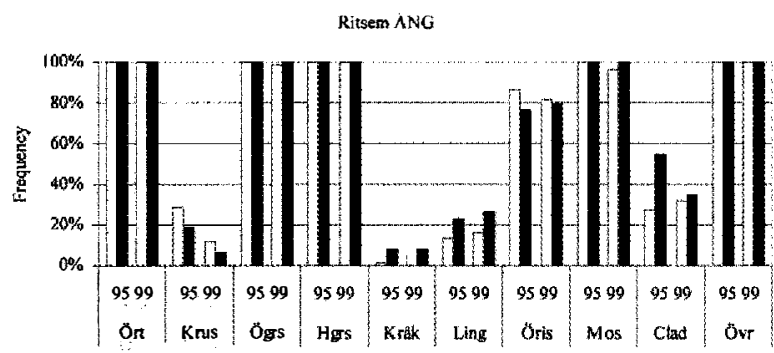

\begin{tabular}{lll}
\hline Factor & Df & Ling \\
\hline Area & 4 & \\
Treatment & 1 & \\
Year & 1 & $*$ \\
& & \\
Year*Area & 4 & $*$ \\
Year*Treatment & 1 & $* *$ \\
\hline
\end{tabular}

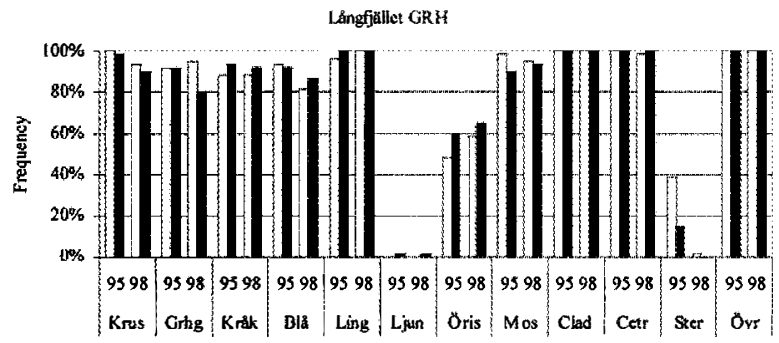

Fig. 16. Proportion of study plots with occurrence of a species or species group at the two inventories on Långfjället's grass heath. Black columns show the fenced plots, white columns show the open plots and the error columns give the standarderror (SE). The tables show the results of logistic regression conducted on each site individually. Abbreviations, see Figure 5.

on the fenced plots. The cover of mosses, on the other hand, increased on fenced plots but remained unchanged on open plots. The differences between open and fenced plots in changes in the degree of cover are significant in both cases. Regardless of fencing, the other dwarf shrubs decreased their degree of cover, whereas the group 'other' (litter, stones, bare soil and water) increased.

Mosses, and other dwarf shrubs, make up most of the ground layer of the dry heath at Ritsem. Only Cladonia/ Cladina show significant changes in cover as a result of fencing. They increased on open plots but decreased on fenced plots.

\section{Frequency}

Figure 16 shows the proportion of study plots containing a species/species group of the three vegetation types at the two inventories. The tables in the same figures show the results of the logistic regressions individually calculated for each site and vegetation type. Only the species/species groups that showed significant differences in frequency between years, as a response to fencing or both, are included in the tables.

On the meadow with low herbs in Ritsem, Vaccinium vitis-idaea shows a significant change in occurrence as a response to fencing. The frequency increased on both fenced plots and open plots, but the increase was somewhat larger on open plots. On the dry heath, the frequency of Empetrum hermaphroditum increased on fenced plots but decreased on open plots, whereas Vaccinium vitis-idaea and Deschampsia flexuosa increased on open plots but decreased on fenced plots.

No species or species group showed any significant change in frequency on Långfjället's grass heath.

\section{Droppings}

No droppings of elk or hare were found on the study plots on the three types of vegetation (Table 21). At the inventory in 1995, all plots on Långfjället's grass heath were open, and reindeer droppings found on the plots subsequently fenced disappeared by 1998 . On the open 
Table 21. Number of piles of reindeer droppings per hectare on fenced and open plots at the two inventories on Långfjället's grass heath and at Ritsem (meadow with low herbs as well as dry heath).

\begin{tabular}{lccc}
\hline Plots & $\begin{array}{c}\text { Långfjället } \\
\text { Grass heath }\end{array}$ & $\begin{array}{c}\text { Ritsem low } \\
\text { herb meadow }\end{array}$ & $\begin{array}{c}\text { Ritsem } \\
\text { dry heath }\end{array}$ \\
\hline Fenced 1995 & $399 \pm 7$ & $909 \pm 201$ & - \\
Fenced 1997 & $-2)$ & - i) & - \\
Open 1995 & $728 \pm 42$ & $1150 \pm 194$ & $5167 \pm 2017$ \\
Open 1997 & $294 \pm 242^{2)}$ & 643 & $2076 \pm 1415$ \\
\hline
\end{tabular}

plots, the frequency of reindeer droppings had more than halved between the years, and the same applied to the meadow with low herbs at Ritsem. Also on the dry heath, there was a marked reduction in piles of droppings; here there appears to be a relationship between the number of reindeer in Sörkaitum's Saami village (Figure 3) and the number of piles of droppings.

\subsection{Tjuolmajaure and Puollanvare}

\section{Species present}

The study plots at Tjuolmajaure and Puollanvare are all in the vegetation type named dry dwarf-shrub heath. Table 22 shows the number of taxa (species, species groups, genus, etc.) found in the two inventories at both sites, and all taxa are listed in the Appendix. The fact that some 'difficult' species (e.g. lichens belonging the genus Cladonia) sometimes have been grouped together, causes some difficulty in deciding from the species list whether one of these species has actually occurred, or whether it has disappeared over the years.

Festuca ovina, Pedicularis lapponica, Empetrum hermaphroditum and Vaccinium uliginosum are examples of species found on the open plots at Tjuolma jaure in 1997, but not in 1999. Within the fenced plots, Solorina crocea shows the same pattern. Juncus trifidus was present during the initial phase only on the fenced plots, but in 1999 was also present on the open plots.

Table 23. Shannon's diversity index for fenced and open plots at Tjuolmajaure and Puollanvare.

\begin{tabular}{lcc}
\hline Plots & Tjuolmajaure & Poullanvare \\
\hline Fenced 1997 & 2.163 & 2.394 \\
Fenced 1999 & 2.915 & 2.719 \\
Open 1997 & 2.407 & 2.763 \\
Open 1999 & 2.759 & 2.875 \\
\hline
\end{tabular}

Table 22. Number of taxa for fenced and open plots at Tjuomajaure and Poullanvare.

\begin{tabular}{lcc}
\hline Plots & Tjuolmajaure & Poullanvare \\
\hline Fenced 1997 & 42 & 37 \\
Fenced 1999 & 39 & 39 \\
Open 1997 & 43 & 41 \\
Open 1999 & 38 & 35 \\
\hline
\end{tabular}

On the open plots at Puollanvare, Juncus trifidus was present in 1997, but not in 1999, and the same applies to Vaccinium myrtillus on the fenced plots; this was also a new species on the open plots at the inventory in 1999.

\section{Shannon's diversity index}

Table 23 shows species diversity for fenced and open plots, calculated in accordance with formula 1. At Tjuolmajaure and Puollanvare, diversity had increased significantly, on both open and fenced plots $(p<0.01$ and $p<0.05$, respectively, Mixed-model ANOVA).

\section{Ordination}

In the ordination diagram (Fig. 17), the fenced plots are separated from the open plots. This applies to both sites and both inventories. The fenced plots are also those that have moved least between years, which suggests that the changes

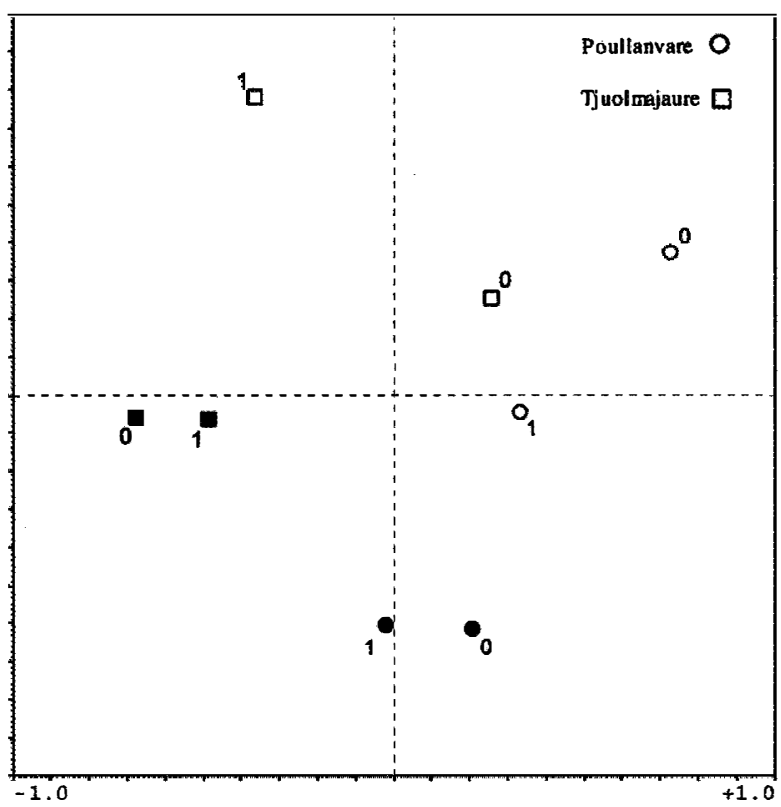

Fig. 17. Ordination diagram (PCA) for study plots at Puollanvare and Tjuolmajaure. Filled symbols represent fenced plots, and the figure in the identification code of the plots refers to the inventory ( $0=$ first inventory, $1=$ second inventory). 
Tjuolmajaure

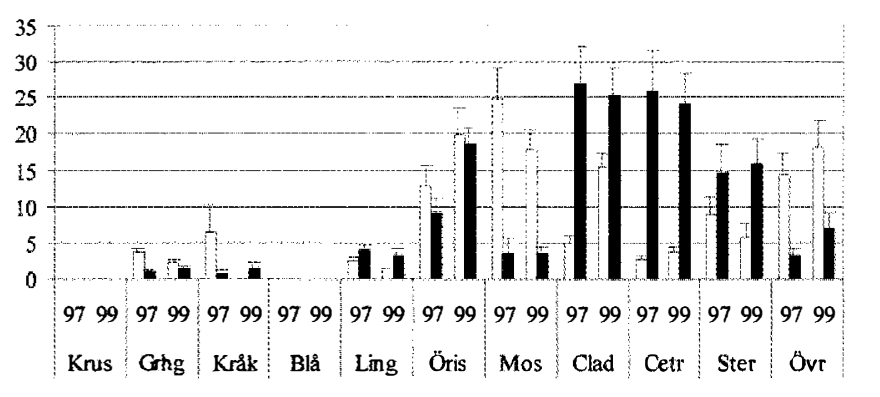

\begin{tabular}{lllll}
\hline Factor & Df & Kråk & Öris & Clad \\
\hline Year & 1 & & $* *$ & $*$ \\
Treatment & 1 & & & $* * *$ \\
& & & & \\
Year*Treatment & 1 & $*$ & & 0.06 \\
\hline
\end{tabular}

Poullanvare

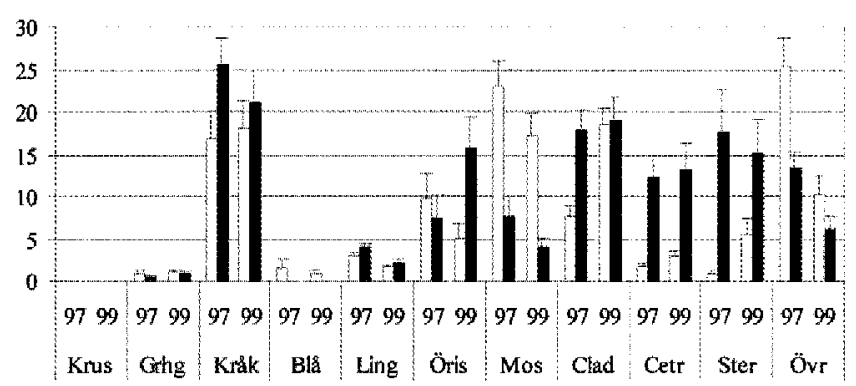

\begin{tabular}{lllll}
\hline Factor & Df & Ling & Clad & Övr \\
\hline Year & 1 & $* * *$ & $* *$ & $* * *$ \\
Treatment & 1 & $*$ & $*$ & $* * *$ \\
& & & & \\
Year*Treatment & 1 & & $*$ & \\
\hline
\end{tabular}

Fig. 18. Cover, per cent, of species and species groups at the two inventories at Tjuolma jaure and Puollanvare. Black columns refer to fenced plots, white columns to open plots, and the error columns show the standard error (SE). The tables show the results of ANOVAs calculated individually for each site. Significance is shown by * for $p<0.05$, ** for $p<0.01$ and $* * *$ for $p<0.001$. Where nothing is shown, the result is not significant. Abbreviations, See Figure 5.

in the vegetation have been small. It is also possible to see that, at the time of the first inventory, the open plots at both sites were fairly similar, but at the second inventory they had moved further from each other in the diagram.

\section{Cover}

Figure 18 shows the percentage composition of the ground cover at the two study sites at the two inventories. The tables in the figure show the results of ANOVA, calculated individually for each site. Only the species/species groups that showed significant differences in the analysis of variance are shown in the table.

At Tjuolmavare, the ground layer on the open plots is dominated by 'other dwarf shrubs', mosses and 'others' (bare soil, litter, stones, etc.), whereas the occurrence of lichens is relatively low. Within the fenced plots, on the other hand, lichens belonging to the genera Cladonial Cladina, Cetraria and Stereocaulon make up more than half of the ground layer. Empetrum hermaphroditum is the only species that shows a significant difference in cover in response to fencing, as it disappeared from the open plots, but increased slightly on the fenced plots. 'Other dwarf shrubs' increased on fenced and open plots, regardless of treatment.

The largest difference between Puollanvare and Tjuolmajaure is that the former has considerably more Empetrum hermaphroditum, on both fenced and open plots. Otherwise, the distribution of species/species groups at these two sites is fairly similar. Cladonia/Cladina increased on the open plots, but remained at a uniform level on the fenced plots, whereas Vaccinium vitis-idaea and 'other' (bare soil, litter, stones, etc.) in general decreased at Puollanvare over the years. 

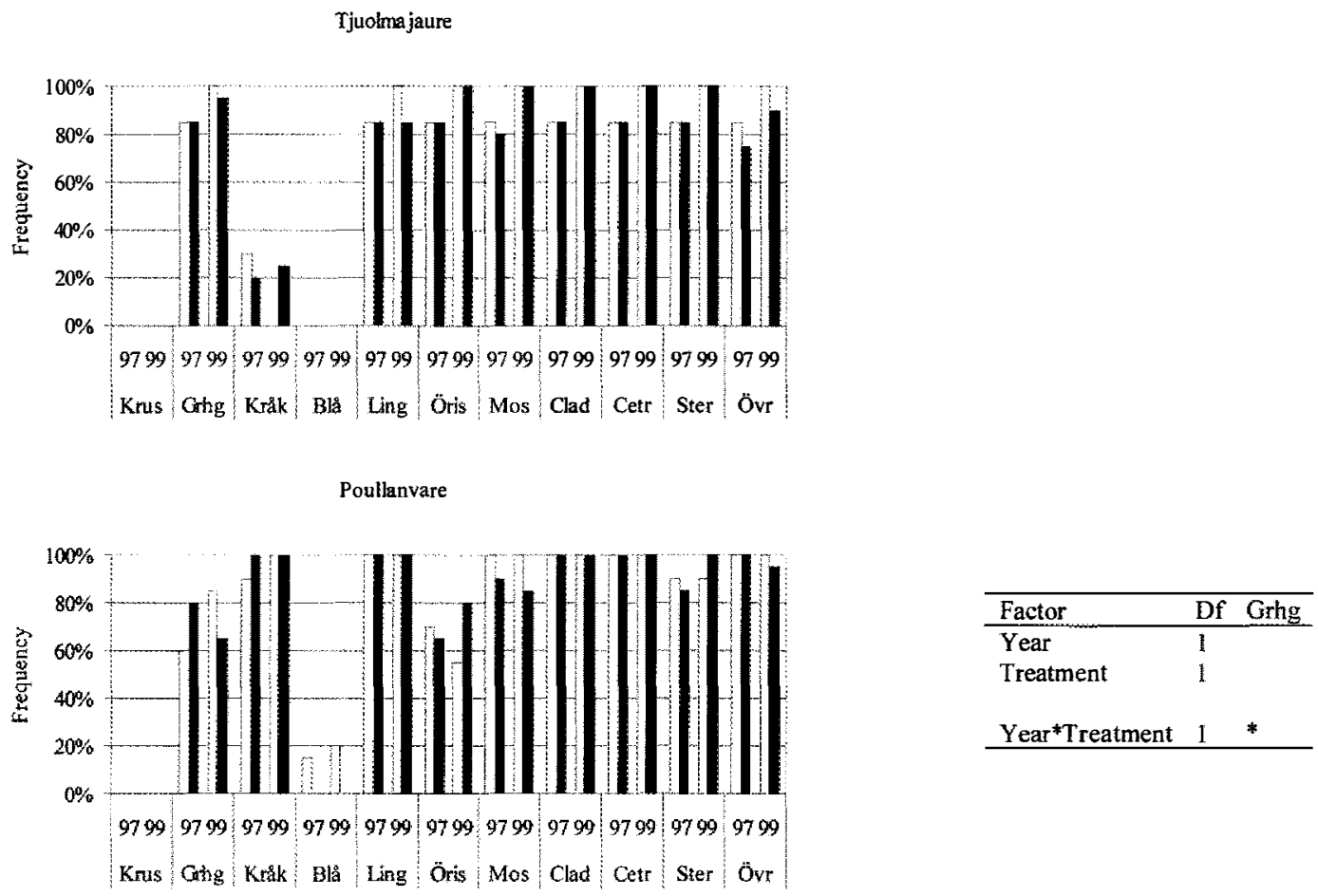

Fig. 19. The proportion of study plots with occurrence of a species/species group at the two inventories at Tjuolmajaure and Puollanvare. Black columns refer to fenced plots and white columns to open plots. The tables show the results of the logistic regression calculated individually for each site. Significance is shown by * for $p<0.05$. Where nothing is shown, the result is not significant. Abbreviations, see Figure 5.

\section{Frequency}

Figure 19 shows the proportion of plots with occurrence of a species /species group on the study sites at the two inventories. The tables in the figure show the results of the logistic regression calculated individually for each site. Only the species/species groups that showed significant differences in frequency between years, as a response to fencing or both, are included in the tables.

At Puollanvare, 'other grass/sedges' has become less frequent on fenced plots, but more frequent on open plots, which is the only significant difference between the two sites. 


\section{The WWF-project: Discussion}

Shannon diversity indexes, ordinations and analyses of the species cover showed that exclosure of reindeer and elk for three to four years had a marginal or no effect on the investigated vegetation types. This was expected, because the dynamics of grazed vegetation in general, and grazed vegetation in subarctic and alpine areas in particular, is slow (e.g. Hill et al. 1992, Manseau et al. 1996, Austrheim \& Eriksson 2001), and the duration of the present experiment was short. In plant communities such as those studied here, where reindeer have grazed since the latest ice age, the species compositions and local species pools are determined by their grazers (Zimov et al. 1995, Mulder 1999, Olofsson et al. 2001, see also Jefferies et al. 1994). Succession within these communities is slow. Examples of reindeer-grazed systems with low resilience are given in a study from northern Finland by den Herder et al. (2003). They investigated vegetation changes in exclosures in a Scots pine (Pinus sylvestris) forest and a subarctic heathland; after 13 years, their conclusion was that the vegetation in both communities was still in succession. Another example of a grazed system with low resilience is from North Wales (Hill et al. 1992). In a sheep exclosure experiment, Hill with co-workers observed that the community structure was still not stable after 30 years. Moreover, it was shown that the succession strongly depended on the initial vegetation (Hill et al. 1992).

What will the results be if the present study continues for 25 more years? We do not know: but probably they will resemble those from the 30-year exclosure experiment by Eriksson et al. (1998), that revealed conspicuous effects on the vegetation composition. The results of Eriksson et al. (1998) study demonstrated, among other things, an increase in the lichen carpet cover at the expense of bryophytes, which accords with what other studies of the effect of grazers on subarctic and alpine vegetation have shown. For example, a 50-year exclosure experiment in the Finnish boreal forest gave similar results (Väre et al. 1995). In the Finnish forest, the cover of Cladina stellaris was $63 \%$ inside the fence, and only $4 \%$ outside; the total cover of lichens was $92 \%$ inside and $75 \%$ outside. The total cover of mosses was $1 \%$ and $12 \%$ at ungrazed and grazed sites, respectively. Similarly to the results of Eriksson $e t$ al. (1998), Dicranum spp. benefitted most from grazing (Väre et al. 1995). In the 13-year exclosure experiment by den Herder (2003), C. stellaris, C. rangiferina, C. mitis, C. uncialis, Cladonia spp. and Cetraria nivalis decreased with grazing, whereas they saw no significant changes in bryophyte cover. At Ungava Bay in Canada, Manseau et al. (1996) used sites naturally inaccessible to reindeer as reference areas, when studying their effect on vegetation composition. At ungrazed sites, the lichen cover was $42 \%$, whereas it was only $4 \%$ at grazed sites; for mosses the figures were the opposite, $4 \%$ and $22 \%$, respectively. In another descriptive study, Helle \& Aspi (1983) also showed that the relative abundance of Cladina spp. increased with decreasing grazing pressure in Finnish Lapland. These examples accord with several other studies of the effects of reindeer on vegetation, reviewed by Suominen \& Olofsson (2000).

In the WWF-study, the three-way interactions between yearxvegetation $\times$ treatment were not significant, indicating that the effect grazers have on the vegetation was uniform, or more correctly, that the absence of effects was uniform. Once again, what would have been the result had the present study been running for 30 years instead of three to four years? On the dry heath at Puollanvare (Tavvavuoma in the WWF-study), in the 30-year study by Eriksson et al. (1998), Cetrarianivalis, Cladina arbuscula andStereocaulon paschale increased owing to the exclusion of reindeer and elk, but in the Birch forest heath type with lichens at Järämä, $10 \mathrm{~km}$ west of Puollanvare, Festuca ovina, Cladina stellaris, C. arbuscula and Stereocaulon paschale were more abundant inside exclosures than outside. At Puollanvare, $C$. nivalis, which is an important fodder lichen on wind-exposed sites, had increased inside the exclosure. At Järämä, C. stellaris, also an important fodder lichen on sites not exposed to wind (Eriksson et al. 1981, Warenberg et al. 1997), showed increased abundance inside the exclosure as compared with the control plot. There are more examples of differences between responses of vegetation types to terminated grazing. In a 7- and in an 11-year-old exclosure experiment in Finnmark, northern Norway, changes in plant community structure were studied (Moen \& Oksanen 1998, Olofsson et al. 2002). Two arctic-alpine plant communities were used, an unproductive snowbed and a considerably more productive tall-herb meadow. In the latter, the effect of exclosure was not as extensive as in the low-productive snowbed. The effect of summer reindeer grazing on tundra heath vegetation at four sites with different climate and different vegetation composition, was studied by Olofsson et al. (2001); they used a fence erected 30 years earlier. At two sites, graminoids dominated the grazed areas, while ericoid dwarf shrubs had almost disappeared. At the other sites, neither graminoids nor ericoids increased, owing to grazing. In the study by Manseau et al. (1996), the lichen carpet on the shrub tundra was reduced, whereas it was not affected in stands of Betula glandulosa. 


\section{Species diversity}

The most commonly used hypothesis on the effect of herbivory on species diversity is the intermediate disturbance hypothesis (Grime 1973, Fox 1979). According to this, diversity is low in the absence of disturbance, because of competitive exclusion, and high at intermediate levels when competitive exclusion is hindered. Diversity is also expected to be low at high levels of disturbance, when only the most tolerant species persist. One problem with the intermediate disturbance hypothesis is that it is difficult to determine a priori which disturbance level is low, intermediate, or high, and thereby test the hypothesis. Milchunas et al. (1988) modified the intermediate disturbance hypothesis, and suggested that a disturbance is determined by the grazing history of the vegetation and the mode of plant competition within it, i.e. for a community adapted to a certain grazing pressure, every deviation from that pressure is a disturbance. Furthermore, Olff \& Ritchie (1998) theorise that large herbivores always affect plant diversity positively through several mechanisms. However, at high densities, such as in intensive livestock grazing, large herbivores can graze non-selectively, leaving only a few tolerant plant species, hence reducing plant diversity. Thus, according to the intermediate disturbance hypothesis, we would expect a smaller number of species within our fenced plots compared with open control plots, provided that the grazing pressure had been on an intermediate level. However, if the grazing pressure has caused a high level of disturbance to the vegetation, which is implied by many observers e.g. Lundh (1998), Oksanen (1992), and Ihse \& Allard (1995), the number of species should increase within the fenced plots, as a result of endurable conditions for more species. An increased number of species within fenced plots is also to be expected according to the theory of Olff \& Ritchie (1998).

However, as has already been pointed out, there were no particular effects on the number of taxa present or on Shannon diversity indices, in consequence of terminated reindeer and elk grazing; this is an expected result, likely to be caused by the short duration of the experiment. Large numbers of species had not time to become dispersed and established on the plots during the two to four years for which the fences have existed, and no large changes in the proportions between species had time to develop. A species that has disappeared from the local species pool will have considerable difficulty in re-establishing via seed and other long-distance dispersal options, such as fragmentation, in arctic and subarctic areas (Amen 1966, Kudo 1993, Stöcklin \& Bäumler 1996, Pyšek 1997). Thus, although our results imply that diversity in the investigated area is not affected by the grazing of large herbivores, this is probably not the case. In general, grazing appears to increase diversity on heathlands (Suominen \& Olofsson 2000, Austrheim \& Eriksson 2001). In Pinus sylvestris forests (Finnish Lapland), where several studies of diversity after reindeer grazing have been performed, the results suggest that grazing increases diversity and that the increase is due to reduced competition of the dominant species, Cladina spp. (e.g. Helle \& Aspi 1983, Väre et al. 1995). However, in the 30 -year exclosure experiment by Eriksson et al. (1998), in the same area as the present study, no significant differences in species number or diversity between open and fenced plots were detected, although other conspicuous changes in the vegetation within fenced plots had occurred.

The dry heath at Ritsem has more taxa (57-72) than the same vegetation type at other sites (18-43), which is probably due to the calcareous bedrock and the humidity of the site. It is difficult to compare, accurately and meaningfully, the number of species or species groups between sites, but it may be noted that the number of species found in a Pinus sylvestris forest in northwest Finland was between 11 and 22 (Helle \& Aspi 1983), whereas in the study by Eriksson et al. (1998) the number of taxa found was between 28 and 39 . There were conspicuously large increases in the number of species between inventories on the dry heath in Tavvavuoma, Sånfjället and Långfjället. In the open plots on Sånfjället, the number of recorded taxa increased by more than $60 \%$. The reasonfor this is unknown to us, but might involve the reduced number of reindeer that periodically appear in the area, or that the team that carried out the inventory in 1998 was better able to separate lichen species, than the team that made the initial inventory in 1996. Indications of the latter can be seen on the taxalists in the Appendix. The weather conditions before, or between, inventories might also have had some effect, but the data available are insufficiently detailed to allow this to be determined. Whatever the reason for the increase, the result shows the importance of including different types of vegetation in surveys, to avoid generalizations. The Shannon diversity indices for the dry heath on Sånfjället increased by $34 \%$ between inventories of open plots, and $36 \%$ between inventories of fenced plots, which is more than twice as much as if the proportions between taxa were the same; this indicates that the degree of evenness between taxa has increased. This may also be an effect of splitting a large group of taxa into several smaller ones.

\section{Ordinations}

Within plant ecology, ordination is of ten used to arrange habitats in a two-dimensional space. Here we use the method to discover changes in species presence and cover due to changes in grazing. No conspicuous effects of the cessation of grazing by large herbivores were seen in the PCA-ordination. The different sites with vegetation type 'Birch-forest heath type with mosses', 'Birch-forest heath type with lichens' and 'Dry heath' differed distinctly in vegetation composition. This dispersal in the ordination 
space was unknown, but is very significant for the study, as it facilitates some generalisation of future results, since the vegetation types used represent a larger part of the vegetation of the mountain range (Table 7).

In an interim-report on the present study (Eriksson et al. 1999), 'Fencing' was used as an environmental factor in an ordination of all vegetation types on Långfjället and Sånfjället, and this factor was, unsurprisingly, not statistically significant. However, the environmental factor 'Time' indicated significant changes in the plant community, irrespective of grazing treatment. Thus, the open and fenced plots moved similarly in the ordination space. This can be explained by the reduced grazing in the areas, and is also implied by the reduction in reindeer droppings at all sites, except the vegetation type 'Birch-forest heath type with lichens' at Långfjället. At this site, exclosures were suggested to affect the vegetation.

\section{Cover of the species}

Grasses are generally expected to be resistant to trampling and grazing (Emanuelsson 1984, Hik et al. 1992, Wegener \& Odasz 1997, Mulder 1999); grasses might even be favoured by grazing (e.g. Moen et al. 1993, Olofsson et al. 2001). Crawley (1997) states that the ability of grasses to withstand grazing is their most famous trait. Intense sum- mer grazing by reindeer in northern Norway changed the vegetation, from moss-rich heath tundra into graminoiddominated steppe-like tundra vegetation (Olofsson et al. 2001). The basal meristems of grasses, their large resource reserves belowground, together with their high photosynthetic rate, quick leaf turn-over and nutrient absorption, and low production of secondary compounds, all increase their capacity for regrowth after grazing (Archer \& Tieszen 1980, Chapin 1980). Grasses may respond to grazing through several mechanisms, e.g. by increasing axillary shoot production, increased number of leaves per shoot or by delayed senescence. Furthermore, reduced self-shading and an increased proportion of young leaves may also be advantageous for the growth rate of grasses. However, low nutrient availability limits plant growth in subarctic and alpine areas, especially of grasses (Chapin et al. 1986, McKendrick et al. 1980). Consequently, grasses are usually of less importance in plant communities in these areas. But, according to Zimov et al. (1995), a high grazing pressure on tundra may change the vegetation towards a grassdominated steppe owing, for instance, to increased nutrient turnover and thaw-depth of the ground. This hypothesis was supported by a recent study of the vegetation along a 40-year-old fence separating different grazing regimes in northern Fennoscandia (Olofsson et al. 2004).

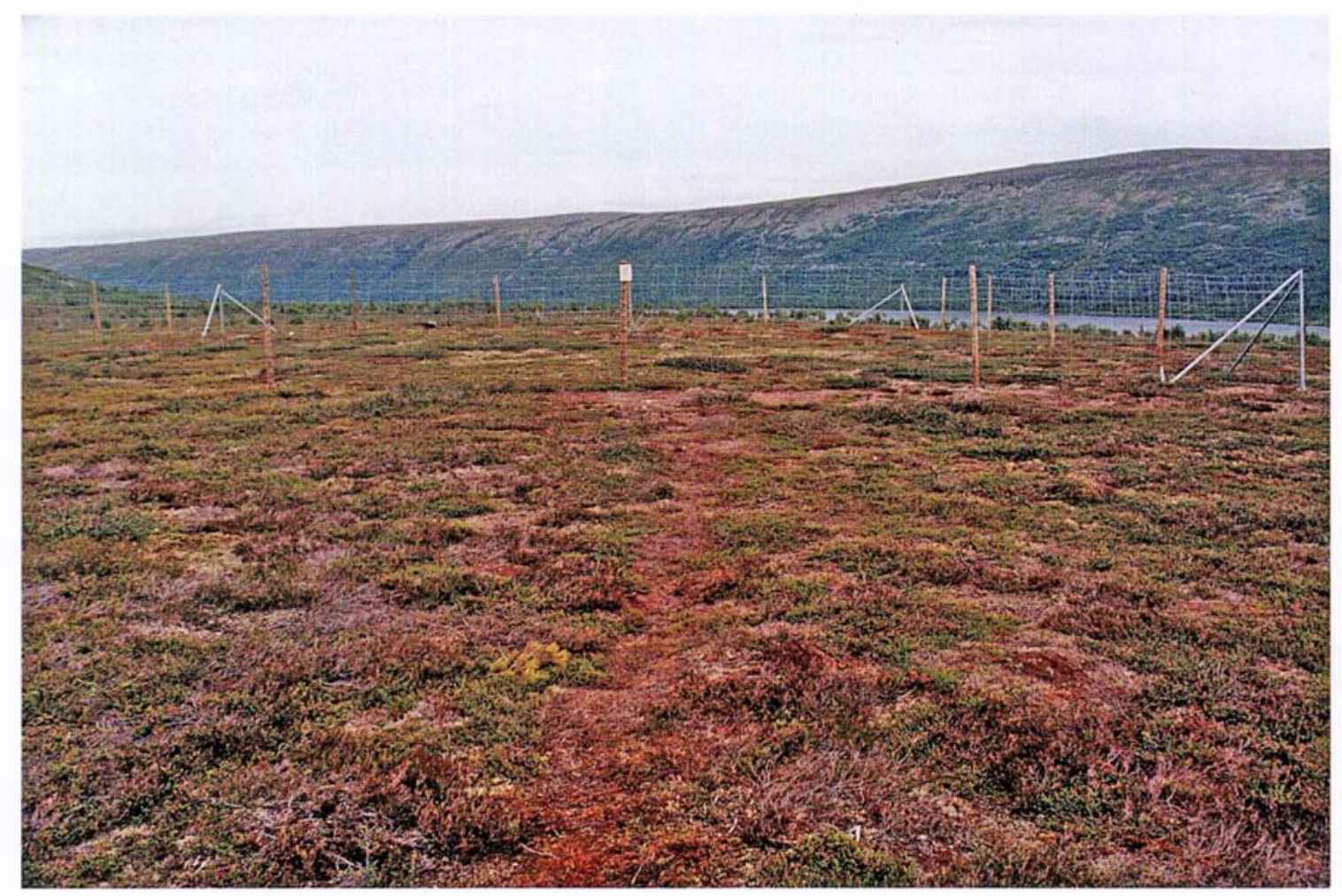

Fig. XXIV. The mountain vegetation is highly sensitive to trampling. Here, a path has been created in the space of two or three years by tourists who have diverged from the Linnaeus trail on Långfjället, to read the sign beside a fenced sample plot. The vegetation type at the site is Dry heath with lichens. 
Results from the few studies of the regrowth capacity of forbs after grazing are not conclusive; for example, Mulder \& Ruess (1998) and Olofsson et al. (2002) showed quick regrowth of forbs after exclosure of grazers, whereas Moen et al. (1993) conclude that forbs generally suffer from grazing. When the vegetation along fences was studied, herbs were the only growth forms that did not respond significantly to summer grazing by reindeer (Olofsson et al. 2001). In the same study, d warf shrubs were replaced by graminoids in consequence of grazing, which is consistent with previous findings (Clarke et al. 1995, McKendrick et al. 1980). Compared with grasses and forbs, dwarf shrubs have a poor ability to compensate for defoliation and grazing (Mulder 1999). However, in a recent study, Vaccinium myrtillus and $V$. vitis-idaea increased most after herbivore exclosure (Olofsson et al. 2004b).

Lichens have a low growth rate (e.g. Kärenlampi et al. 1975). A calculated maximum dry mass production of reindeer lichens in northern Finland is $175 \mathrm{~kg} \mathrm{ha}^{-1} \mathrm{yr}^{-1}$, or $0.06 \mathrm{~g}$ per gram lichen and year (Kumpula et al. 2000). These figures are in accordance with those presented in another study in the same area (den Herder et al. 2003), and predictions in the North Swedish mountain region (Eriksson 1979, Eriksson 1984a). However, the growth of Cladina stellaris may occasionally be as much as $0.17 \mathrm{~g}$ $\mathrm{g}^{-1} \mathrm{yr}^{-1}$ (den Herder et al. 2003), which is almost the same as the growth of the dwarf shrub Empetrum hermaphroditum (Weih \& Karlsson 1999). With these, on average, low growth rates, it is understandable that dense mats of lichens are considered as one of the most sensitive vegetation types in Fennoscandia. Moreover, results indicate that heavy grazing reduces the growth rate of lichens to even lower values (den Herder et al. 2003). The abundance of lichens is not reduced just by grazing, but by trampling as well, since trampling easily destroys dry lichens (Manseau et al. 1996). Not only does lichen abundance decrease in areas utilised by reindeer (Arseneault et al. 1997, Allard et al. 1998, Eriksson et al. 1998, Suominen \& Olof sson 2000), but there may also be a change in the relative abundance of different lichen species in such areas, since reindeer graze selectively (Danell et al. 1994), and resistance to grazing and trampling varies between lichen species (Klein 1987). Response of the bryophytes to reindeer grazing is inconsistent. In some studies, their performance has been favoured by grazing, whereas in others it is hampered. Since they are mostly weak competitors, their abundance in ground vegetation may increase, owing to selective grazing of their competitors (Helle \& Aspi 1983, Oksanen \& Virtanen 1995, Väre et al. 1995). However, as they are sensitive to trampling (Chernov 1980 in Zimov et al. 1995), intense grazing/trampling may reduce the abundance of bryophytes and even promote a transition of moss-rich heath tundra into graminoid-dominated steppe-like tundra (Olofsson et al. 2001). Furthermore, paradoxically, browsing by the other large herbivore in subarctic Sweden, the elk, may reduce the abundance of bryophytes and increase the abundance of their competitors, such as lichens of the genus Cladina, probably as a consequence of changes in the microclimate close to the ground towards drier conditions (Suominen et al. 1999).

In our study, there were no significant three- or four-way interactions in the models. This means, among other things, that no taxa responded significantly differently to exclosure treatment owing to the surrounding and competing species. Moreover, no significant differences in responses of taxa to fencing between different sites were detected, i.e. latitude did not affect the outcome. However, as the duration of the present study is so short, it was highly improbable that such differences would be detected. Seven taxa/groups: Deschampsia flexuosa, Herbs, Vaccinium myrtillus, $V$. vitis-idaea, Cetraria spp., Cladina spp./Cladonia spp., and

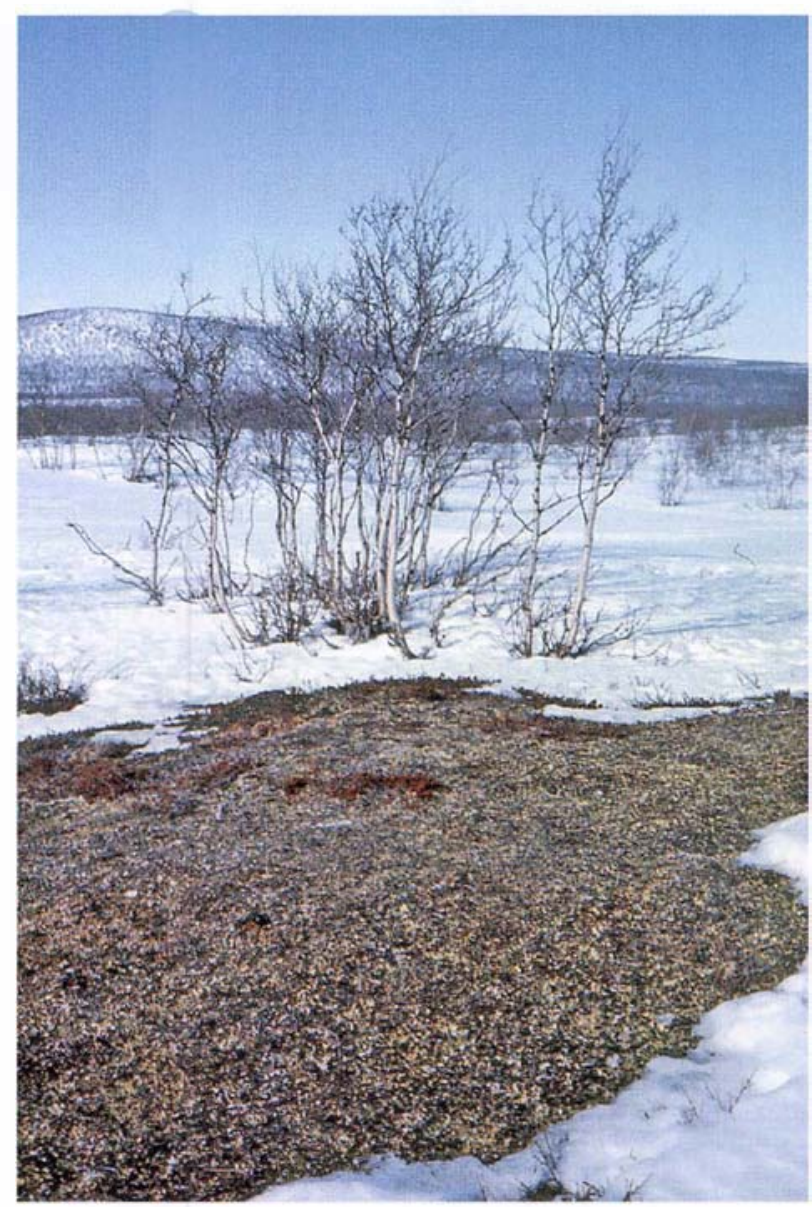

Fig. XXV. Some sites have less snow than others, which considerably affects the vegetation. These patches/sites are more exposed to cold, because they lack an insulating snow cover in winter. The cold prevents the growth, e.g. of crowberry (Empetrum). The contrasting phenomenon, the snowbed, is better known. 


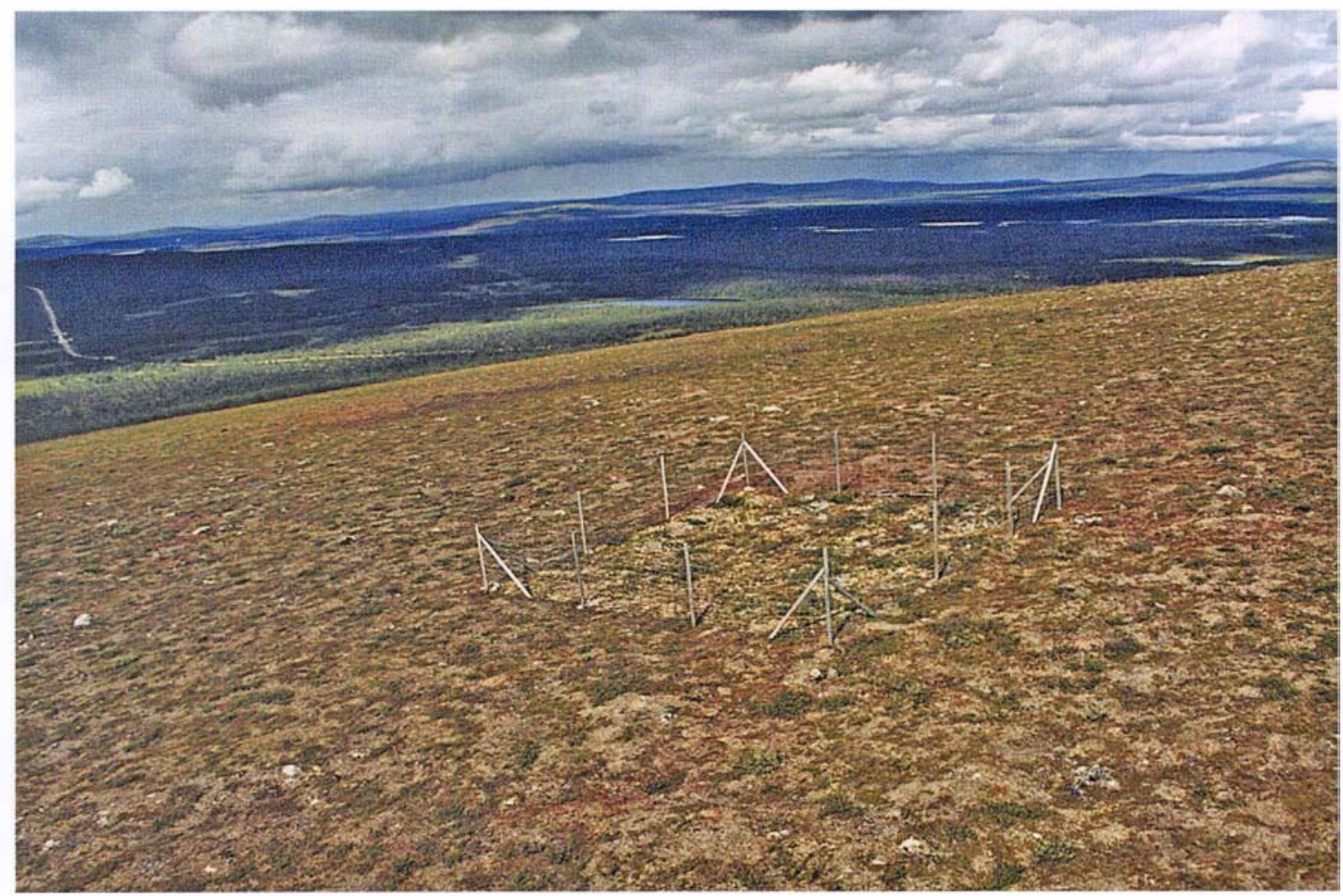

Fig. XXVI. After 30 years without grazing and trampling by reindeer and elk, the lichen vegetation has changed markedly. The fenced sample plots are situated (a) at Järämä and (b) at Poullanvare; the fences were erected in 1968. Photo: O. Eriksson, 1998.

Mosses, responded to fencing (i.e. timexfencing), but no major changes of vegetation communities were detected. $V$. vitis-idaea was the most responsive taxon in our study, i.e. it had the highest number of significant changes due to fencing; however, the response was ambiguous. $V$. vitis-idaea increased within exclosures in the Birch forests heath type with mosses at Tavvavuoma and Fulufjället, but decreased on Sånfjället. At the same site, V. vitis-idaea increased on the Dry heath. In a recently performed fouryear exclosure study in northern Fennoscandia, Olof sson et al. (2004b) found increased abundance of V. vitis-idaea when reindeer, Norwegian lemmings (Lemmus lemmus), and Grey-sided voles (Clethrionomys rurocanus) were prevented from grazing, but not when only the reindeer were excluded. In the 30-year study (Eriksson \& Raunistola 1996), V. vitis-idaea decreased due to fencing in a Birch forest heath type with lichens (at the Kalatonjärvi site), whereas in the same study, another evergreen dwarf shrub, Empetrum hermaphroditum, tended to be more abundant inside the fence than on the open plot, adjacent to the plots on the Dry heath of Tavvavuoma in the present study.

In all four plots of the 30-year study (Eriksson \& Raunistola 1996), Cladina spp. increased in abundance, whereas mosses decreased, e.g. Dicranum scoparium. The lichen Cetraria spp. had higher abundance on fenced plots than on open ones at two Dry heath sites in this study. At the Birch forest heath type with lichens, there were no significant changes between open and fenced plots. In the present study, the response of Cladina sp. to fencing was not consistent; the abundance increased in the Grass heath but decreased in the Dry heath of Ritsem. Cetraria sp. also responded inconsistently to fencing, increasing at two sites and decreasing at a third. Our inconclusive result regarding the response of lichens to fencing was expected, since the treatment period is so short compared with the long lifespan of these 'plants' (Jefferies et al. 1994). However, Olofsson et al. (2004b) recorded increased abundance of Cladina mitis (a species close to C. arbuscula) on fenced plots after only four years without reindeer grazing.

\section{Shrub and tree canopy cover}

Although browsing of shrubs and trees is important in the reindeer diet (Warenberg et al. 1997, Warenberg 1977, Eriksson et al. 1981) especially during springtime, effects of herbivores on them are poorly studied (Mulder 1999). The results of the studies known to the authors are inconsistent. In a Canadian study, the ground cover of Betula glandulosa was significantly lower on grazed areas than on ungrazed areas (Manseau et al. 1996). Warenberg (1977) described negative effects of reindeer grazing on Salix glauca and Sorbus aucuparia at Ottfjäll 


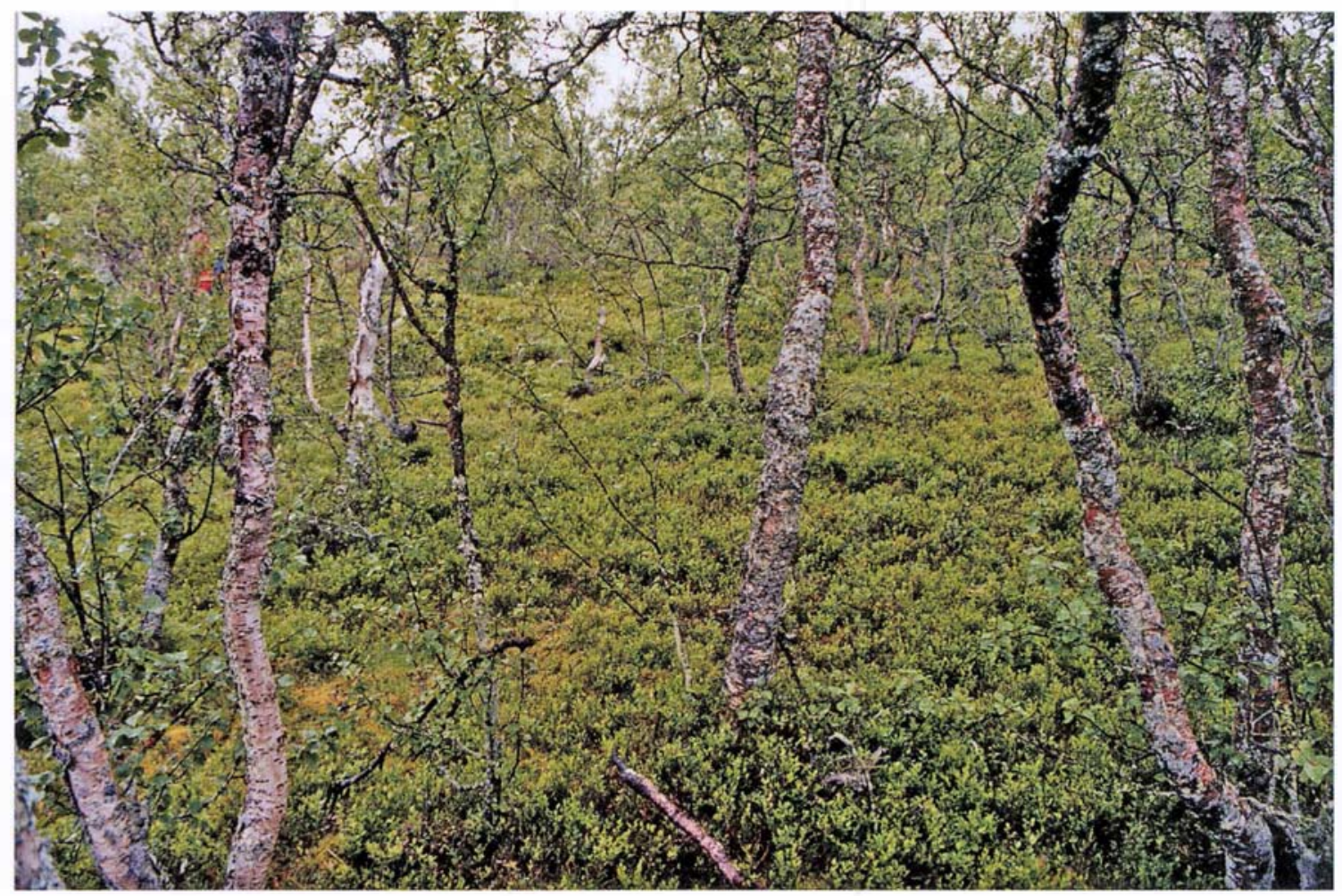

Fig. XXVII. Moss-rich mountain birch forest below Sonfjället, in which Vaccinium myrtillus dominates the field layer. On some birch trunks, the snow lichen (Parmelia olivacea) indicates the man-high winter snow depth.

in Jämtland, Sweden. It has also been shown that reindeer grazing may prevent development of new forest after outbreaks of autumnal moth (Epirrita autumnata) (Lehtonen \& Heikkinen 1995). However, in north Scandinavia, the cover of B. puberscens ssp. czerepanovii, Salix glauca and Sorbus aucuparia was not changed by a 7-year exclosure of folivorous mammals (Moen \& Oksanen 1998). Reindeer grazing and trampling may also favour birches via increased germination of seeds, owing to gap formation in the vegetation (Helle et al. 1998 in Olofsson 2001).

There were unexpected reductions in the shrub canopycover in the vegetation type "Birch forest heath type with lichens' in Tavvavuoma and Fulufjället, subsequent to fencing. The cause is unknown, but a probable reason is that larger shrubs have grown into trees and only small shrubs are left in the class.

\subsection{Concluding thoughts}

As appears from the accounts of early travellers in Lapland, in former historical circumstances reindeer-grazing was a considerable asset.

During the 19th century, and at the beginning of the 20th century, the grazing situation changed radically. Previously, the Saamis, irrespective of their citizenship, had been able to move between countries with their herds, as was most favourable for pasturage. Subsequently, the borders of the national states were closed, in consequence of which competition for grazing increased markedly. Immigration to northern Lapland from the Grand Duchy of Finland took place at the same time as the ability of the Swedish Saamis to move at will to the summer grazings in Norway was restricted. Overcrowding in the northern parts of the Swedish reindeer-husbandry area gradually became so great that the authorities began to organise extensive, obligatory 'dislocations'.

Those Saamis affected by the obligatory moves took with them an extensive form of reindeer husbandry, based principally on meat production, and developed in the northern part of the Scandes where, during the snowfree period, the terrain allows rather free movement of the herds, determined mainly by the availability of pasturage, by wind direction, by topographic features such as precipices, valleys and glaciers, and to some extent by the need to watch over the reindeer herds.

In the intermediate and southern Saami communities, the form of reindeer husbandry was traditionally intensive, and implied controlled herding of the reindeer during most of the year. This form of husbandry was based on all of the benefits that could be obtained from the reindeer, but included hunting and trapping. The collision between the 
various forms of husbandry was intense, and led to the permanent overexploitation of the grazing resources, in particular the lichen grazings.

The measures so far applied to bring about a palpable and permanent reduction of the reindeer stock-whether undertaken on the initiative of the reindeer owners (the Saami communities) or by the State - have had little positive effect in the longer term. Neither the biomass nor the species composition of the grazed plants appears to have been favourably affected.

A short period of prevented reindeer and elk grazing does not change the diversity or species composition of the field layer in the Swedish mountain range. The results from the present and earlier studies imply that, in order to understand the effect of large herbivores on vegetation in the Fennoscandic mountain range, there is a need for long-term experiments in different types of subarctic and alpine vegetation. Thus, the succession in the investigated areas was slow.

We do not know what the vegetation of the Swedish mountain chain would look like without managed large grazers. Nevertheless, according to theory and results from earlier studies discussed above, it would look quite differ- ent from today. Probably, we would have much larger and thicker lichen mats and fewer mosses. It is also probable that the abundance of graminoids would be lower, as these are favoured by grazing and trampling. However, it is far from certain that diversity would decrease.

The annual air-temperature means have fallen in Scandinavia during the two latest 30 -year standard periods (1931-60 and 1961-90), and the glaciers on the west side of the Scandes are growing rapidly, whereas the size of glaciers on the east side is unchanged (Björn et al. 2000). Nevertheless, the global mean air-temperature is predicted to rise by $1-3.5^{\circ} \mathrm{C}$ by the year 2100 (Houghton et al. 1996) and may push isotherms $150-550 \mathrm{~km}$ farther north; consequently, the distribution, abundance and accessibility of most plant species will be affected. Further, increased temperatures lead to increased nutrient availability for the vegetation. Grasses will gain from this, whereas slowgrowing species will decrease; the abundance of dwarf shrubs will probably increase, which may be negative for the reindeer, as lichens may be out-competed by the dwarf shrubs (Björn et al. 2000). Thus, the future climate in Swedish mountain areas will determine the vegetation there at least as much as the large herbivores. 


\section{References}

Abrahamsson, T. 1975. Till minne av Stora Sjöfallet. In: STF:s årsskrift 1975: 274-312.

Albertsson, J., Andersson, L.J., Renhorn, K.-E., Sehlstedt, A. \& Williamson, M. 1986-1987. Vegetationskarta, bladen Karesuando, Soppero och Lannavaara. - Lantmäteriet, Luleå.

Allard,A. 2001. Vegetation changes in mountain areas-Adetailed study by aerial photo - based on remote sensing and spectral radiometry. - Licentiate thesis, Department of Physical Geography and Quarternary Geology, Stockholm University, Stockholm. 88 pp.

Allard, A. 2003. Vegetation changes in mountain areas. - A monitoring methodology based on aerial photographs, high -resolution satellite images and field investigations. - Thesis, Department of Physical Geography and Quarternary Geology, Stockholm University, Stockholm.

Allard, A., Ihse, M. \& Nordberg, M. 1998. Vegetationsförändringar i fjällen - metodstudier i norra fjällen med hjälp av IRF-flygbilder och satellitbilder. -WWF, Solna.

Amen, R.D. 1966. The extentand role of seed dormancy in alpine plants. - Q. Rev. Biol. 41: 271-281.

Andersson, G., Gustavsson, K.-J. \& Lindström, T. 1971. Rödingen i Rösjöarna på Fulufjället. - Information från Sötvattenlaboratoriet, Drottningholm.

Andersson, L. 1982. Vegetationskarta över de svenska fjällen. Kartblad 22. - Stockholm.

Andersson, L., Grundsten, C., Rafstedt, T. \& von Südow, U. 19781984. Vegetationskarta över de svenska fjällen. Blad 1-220. - Naturvårdsverket, Stockholm.

Andersson, R.M. (ed.) 1982. Population dynamics of infection diseases: Theory and application. Chapman \& Hall, London.

Ångström, A. 1953a. Atlas över Sverige. Sheet: 25-26. Temperatur, humiditet. - Stockholm.

Ångström,A. 1953b.Atlasöver Sverige. Sheet: 27-28. Maximi-och minimitemperaturer, vegetationsperiod m.m. - Stockholm.

Ångström, A. 1974. Sveriges klimat. - AB Kartografiska Institutet. Stockholm.

Anon. 1977. Naturgeografisk regionindelning av Norden. -Nordiska ministerrådet (NUB) 1977: 34. Stockholm.

Archer, S.R. \& Tieszen, L.L. 1980. Growth and physiological responses of tundra plants to defoliation. - Arctic Alp. Res. 12: 531-552.

Aronsson, K.- $\AA$. 1991. Forest reindeer herding. An archaeological and palaeoecological study in northern Sweden. - Umeå.

Aronsson, K.- $\AA$. 1995. Samiska kulturmiljöer i Sverige-en forskningsöversikt. - Riksantikvarieämbetet, Stockholm.

Aronsson, K.-Å. 1997. Fjällen som kulturlandskap. In: Olsson, O., Rolén, M. \& Torp, E. (eds.) Hållbar utveckling och biologisk mångfald i fjällregionen. - Rapport från 1997 års fjällforskningskonferens, FRN's rappport serie 98, Forskningsrådsnämnden, Stockholm.

Arseneault, D., Villeneuve, N., Boismenu, C., LeBlanc, Y. \& Deshaye, J. 1997. Estimating lichen biomass and caribou grazing on the wintering grounds of northern Québec: an application of fire history and Landsat data. - J. Appl. Ecol. 34: 65-78.
Arwidsson, Th. 1926. Floristiska notiser från Pite Lappmark, huvudsakligen nordvästligaste delen. - Bot. Not. 1926: 209226.

Arwidsson, Th. 1943. Studien über die Gefässpflanzen in den Hochgebirgen der Pite Lappmark. - Acta Phytogeogr. Suecica 17.

Austrheim, G. \& Eriksson, O. 2001. Plant species diversity and grazing in the Scandinavian mountains - patterns and processes at different spatial scales. - Ecography 24: 683-695.

Bäcklin, E. 1982. En turistfärd 1903, bröderna Edvard och Emil Bäcklins resa från Fjällnäs till Storsjö och åter den 22-26 juli 1903, Turistland med kulturland. - Ed. Erik J. Bergström, eget förlag.

Banfield, A.W.F. 1961. A revision of the reindeer and caribou, genus Rangifer. - National Museum of Canada, Bulletin 177: 1-137.

Beach, H. 1981. Reindeer-herd management in transition. The case of Tuorpom Saameby in northern Sweden. - Almqvist and Wiksell, Uppsala.

Bergerud, A.T. 1971. The population dynamics of Newfoundland Caribou. - Wildlife Monographs 25: 1-55.

Bergerud, A.T. 1980. A review of the population dynamics of caribou and wild reindeer in North America. In: Reimers, E., Gaare, E. \& Skjerneberg (eds.) - Proceedings of the 2nd international reindeer/Caribou symposium, Trondheim.

Bergerud,A.T. 1983. The natural population control of caribou. In: Bunnell,F.L., Eastman, D.S. \& Peek, J.M.(eds.)Symposium on natural regulation of wildlife populations. Proceedings of the northwest section, the Wildlife Society. - Forest, Wildlife and Range Experiment Station, University of Idaho, Moscow.

Berglöf, L. 1923. De svenska nordlapparnas flyttningar till Norge. - Stockholm.

Bergman, I., Olofsson, A., Hörnberg, G., Zachrisson, O. \& Hellberg, E. 2004. Deglaciation and colonization: Pioneer settlements in northern Fennoscandia. - J. World Prehistory 18: 155-177.

Bjärvall, A., Franzén, R., Nordqvist, M. \& Ahman, G. 1990. Renar och rovdjur. Tryckindustri, Solna.

Björkman, G. 1939. Kärlväxtfloran inom Stora Sjöfallets nationalpark jämte angränsande delar av Norra Lule Lappmark. - Kgl. Vet. Acad. Avhandlingar i naturskyddsärenden $\mathrm{Nr}$ 2. Uppsala.

Björkman, G. 1963a. Suorvasjöarna före vattenregleringens tid. In: Curry-Lindahl, K. (ed.) Natur i Lappland. - Svensk Natur, Uppsala.

Björkman, G. 1963b. Stora Sjöfallets nationalpark. In: Curry-Lindahl, K. (ed.) Natur i Lappland. - Svensk Natur, Uppsala.

Björkman, G. 1965. Tillägg till Kärlväxtfloran inom Stora Sjöfallets nationalpark jämte angränsande delar av Norra Lule Lappmark. - Kgl. Vet. Acad. Avhandlingar i naturskyddsärenden Nr 2. Uppsala.

Björn, L.O., Callaghan, T., Jonasson, S., Jonsdottir, I-S., Melillo, J., Molau, U., Neill, C., Rapp, A., Schlyter, P. \& Tenow; O. 2000. Fjällens ekosystem i ett förändrat klimat. - Rapport 5085. Naturvårdsverket, Kalmar. 
Boberg, G. 1992. Naturvårdsverkets förslag till policy. In: Nyman, L. \& Jennersten, O. (eds.). Renbeteskonferens WWF 1992. - WWF, Stockholm.

Borgegård, L-E., Björnvall, A. \& Kjellin, P. 1975. Motortrafik i terräng. - SNV PM:621, Statens Naturvårdsverk, Solna.

Carlsson, B. Å., Karlsson, P.S. \& Svensson, B.M. 1999. Alpine and subalpine vegetation. In: Rydin, H., Snoeijs, P. \& Diekmann, M. (eds.) 1999. Swedish plant geography. - Acta Phytogeogr. Suec. 84: 75-90.

Chapin, F.S. III. 1980. The mineral nutrition of wild plants. Annu. Rev. Ecol. Syst. 11: 233-260.

Chapin, F.S. III., Vitousek, P.M. \& van Cleve, K. 1986. The nature of nutrient limitation in plant communities. - Am. Nat. 127: 48-58.

Clarke, J.L., Welsh, D. \& Gordon, I.J. 1995. The influence of vegetation pattern on the grazing of heather moorland by red deer and sheep. II. The impact on heather. - J. Appl. Ecol. 32: 177-186.

Crawley, M.J. 1997. Life history and environment. In: Crawley, M.J. (ed.) Plant ecology, pp. 73-131. - Blackwell Science Ltd, Oxford.

Danell, K., Utsi, P.M., Palo, R.T. \& Eriksson, O. 1994. Food plant selection by reindeer during winter in relation to plant quality. - Ecography 17: 153-158.

de Martonne, E. 1926a. Aréisme et indice d'aridité. - Comptes Rendus Acad. Sci., Paris 182: 1395-1398.

de Martonne, E. 1926b. L'indice d'aridité. - Bull. Ass. Géogr. Fr. 9: 3-5.

de Martonne, E. 1926c. Une nouvelle fonction climatologique: l'indice d'aridité. - Météorologie 2: 449-458.

Degelius, G. 1943. Zur Kenntnis der Flechtenflora um den See Virihaure in Lule Lappmark. (Schwedisch-Lappland). - Bot. Not. 1943: 75-113.

Degerman, E., Engblom, E., Lingdahl, P-E., Melin, E. \& Olofsson, E. 1992. Försurning i fjällen? - Fiskeriverkets sötvattenslaboratorium. Information från sötvattenslaboratoriet 1: 1-112. Drottningholm.

den Herder, M., Kytöviita, M-M. \& Niemelä, P. 2003. Growth of reindeer lichens andeffects of reindeer grazing on ground cover vegetation in a Scots pine forest and a subarctic heathland in Finnish Lapland. - Ecography 26: 3-12.

Du Rietz, G.E. 1924. Studien über die Vegetation der Alpen: mit derjenigen Skandinaviens verglichen. - Veröff. Geobot. Inst. Rübel 1: 31-138.

Du Rietz, G.E. 1942. Linné som fjällväxtgeograf. - Svenska Linné-sällskapets årsskrift vol. XXV, Uppsala.

Eloranta, E. \& Nieminen, M. 1986. Calving of the experimental reindeer herd in Kaarnanen during 1970-85. - Rangifer, Special Issue 1: 115-122.

Emanuelsson, U. 1984. Ecological effects of grazing and trampling on mountain vegetation in northern Sweden. - Doctoral thesis. Dept. of Plant Ecology, Lund.

Eriksson, B. 1986. Nederbörds- och humiditets klimat i Sverige under vegetationsperioden. -SMHI RMK no. 46. Norrköping.

Eriksson, G. 1969. Botanikens historia i Sverige intill år 1800. Almquist \& Wiksell, Uppsala.

Eriksson, O. 1976. Snöförhållandenas inverkan på renbetning. - Meddelande från Växtekologiska Institutionen, Uppsala Universitet, Uppsala 1976:2.
Eriksson, O. 1979. Inventering av Mausjaure samebys betesmarksresurser. In: Fredsförbandsutredningen 1979-09-13. - Försvarsdepartementet, Stockholm.

Eriksson, O. 1980. Effects of forest fertilization on the catering intensity of reindeer. In: Proceeding II, Reindeer/Caribou symposium Röros, Norway 1979. - Trondheim.

Eriksson, O. 1984a. Effekter av skogsgödsling på renbete och renbetning. - Skogsfakta Suppl. 5: 80-87.

Eriksson, O. 1984b. Vinterbete för ren i Talma sameby -Resurser, Utnyttjande, Framtidsaspekter. Slutrapport. - Renförsöksavdelningen, SLU, Umeå.

Eriksson, O. \& Raunistola, T. 1990. Impact of soil scarification on reindeer pastures. - Rangifer Special Issue 3: 99-106.

Eriksson, O. \& Raunistola, T. 1993. Trädlavar som renbete. Slutrapport. - Institutionen för husd jurens utfodring och vård, SLU, Uppsala.

Eriksson, O. \& Raunistola, T. 1996. Dynamik och konstans i fjällväxtlighet. - Världsnaturfonden WWF:s fjällvegetationsprojekt, Vegetationsanalysgruppens lägesrapport arbetsåret 1996.

Eriksson, O., Forslund, A. \& Jungskär, W. 1999. Dynamik och konstans i fjällväxtlighet. - Världsnaturfonden WWF:s fjällvegetationsprojekt, Interimsrapport. Revision nr 1 på Långfjället och Sånfjället.

Eriksson, O., Niva, M. \& Raunistola,T.1998. Långtidsförändringar av fjällväxtlighet. - Några exempel från norra Lappland. In: Olsson, O., Rolén, M. \& Torp, E. (eds.) Hållbar utveckling och biologisk mångfald i fjällregionen, rapport 98:2: 184-198. - Forskningsrådsnämnden, Stockholm.

Eriksson, O., Palo,T.\& Söderström, L. 1981. Renbetning vintertid. Undersökningar rörande svensk tamrens näringsekologi under snöperioder. - Växtekol. Stud. 13, Uppsala.

Eriksson, O., Sandewall, M. \& Wilhelmsson, E. 1987. A model for analysing influence of timber production on lichens for reindeer grazing. - Rangifer 7: 15-32.

Espmark, Y. 1981. Taxonomic notes on the Swedish domestic reindeer, genus Rangifer. - Zool. Scripta 10: 155-159.

Esselin, A. 2003. Storskaligt överbete i fjällen - en myt. - Fjällfokus Vol. 11.

Fjellheim, S. 2004. Fra fongstbasert til nomadisk reindrift i Rørostraktene. - Rangifer 9:13.

Flagstad, $\varnothing \&$ Røed, H. 2003. Refugial origins of reindeer (Rangifer tarandus L.) inferred from mitochondrial DNA sequences. - Evolution 57: 658-670.

Fowler, C.W. 1987. A review of density dependance in populations of large mammals. - Curr. Mammal. 1: 401-441.

Fox, J.F. 1979. Intermediate-disturbance hypothesis. - Science 204: 1344-1345.

Fredén, C. (ed.) 1994. Sveriges Nationalatlas. Volym: Berg och Jord. SNA, Stockholm.

Fries, Th.C.E. 1913. Botanische Untersuchungen im Nördlichsten Schweden. In: Vetenskapliga och praktiska undersökningar i Lappland anordnade af Loussavaara-KirunavaaraAktiebolag. - Uppsala.

Geijer, U. 2003. Renskötselrätt. - Sámiid Riikkasearvi/SSR, Umeå.

Grime, J.P. 1973. Control of species density in herbaceous vegetation. - J. Environ. Manage. 1: 151-161.

Haglund, B. 1966. De stora rovdjurens vintervanor I. - Viltrevy 4: 3 . 
Haglund, B. 1968. De stora rovd jurens vintervanor II. - Viltrevy 5: 6.

Hämet-Ahti, L. 1963. Zonation of the mountain birch forests in northernmost Fennoscandia. -Ann. Bot. Soc. Zool.-Bot. Fenn. Vanamo 34(4): 1-127.

Hansson, A. 1997. Jakt och jordbruk i Jämtlandsfjällen under yngre järnålder och medeltid. Arkeologi i Mittfjärden. Ett symposium kring nya arkeologiska forskningsrön. - Scriptum Vasa pp. 17-135.

Helle, T. \& Aspi, J. 1983. Effects of winter grazing by reindeer on vegetation. - Oikos 40: 337-343.

Helle, T., Kajala, L., Niva, A. \& Särkelä, M. 1998. Poron laidunnuksen vaikutus tundurivikoiden rakenteeseen. In: Hyppönen, M., Penttilä, T. \& Poikajärvi, H. (eds.) Poron vaikutus metsä ja tunduriluontoon. Tutkimusseminaari Hetassa 1997. Metsäntutkinmuslaitoksen tiedonantoja. 678: 132-141.

Hesselman, H. 1932. Om klimatets humiditet i vårt land och dess inverkan på markvegetation och skog. - Medd. Statens Skogsförsöksanstalt 26: 515-559.

Hik, D.S., Jefferies, R.L. \& Sinclair, A.R.E. 1992. Foraging by geese, isostatic uplift and asymmetry in the development of salt-marsh plant communities. - J. Ecol. 80: 395-406.

Hill, M.O., Evans, D.F. \& Bell, S.A. 1992. Long-term effects of excluding sheep from hill pastures in North Wales. - J. Ecol. 80: 1-13.

Höglund, N.H. 1970. Vertebratfaunan inom Lövhögsområdet. Fauna och Flora 65: 137-184.

Höglund, N.H. \& Eriksson, B.R. 1973. Förvildade tamrenars inverkan på vegetationen inomLövhögsområdet. - Forskningssekretariatet, Statens Naturvårdsverk 1973, SNV PM 358.

Hollsten, J. 1774. Afhandling om renen. - Kungliga Svenska Vetenskaps Akademin. Handling 35: 124-147.

Holm, J.O. 1917, 1918 Årsberättelse, Lappfogden i Norrbottens norra distrikt. - Arkiv 1890-1924 BIII:1 Luleå.

Holmberg, P. \& Marklund, H. 1996. Nya svampboken. - Prisma, Stockholm.

Houghton, J.B., Meira Filho, L.G., Callander, B.A., Harris, N., Kattenberg, A. \& Maskell, K. (eds.) 1996. Climate change 1995. - The science of climate change. - Cambridge University Press, Cambridge.

Hult, R. 1881. Försök till analytisk behandling af vaxtformationerna. - Meddel. Soc. pro Fauna et Flora Fenn. 8:1, 1-155.

Hultblad, F. 1968. Övergång från nomadism till agrar bosättning i Jokkmokks socken. Nordiska museet: - Acta Lapponica XIV. Stockholm.

Ihse, M. \& Allard,A. 1995. Vegetationsförändringari renbetesfjäll. Metodstudie i södra fjällen med hjälp av flygbilder i IR-färg. - WWF for Nature report No. 2: 95.

Ingold, T. 1980. Hunters, pastoralists and ranchers. Reindeer economics and their transformations. - Cambridge University Press, Cambridge.

Jefferies, R.L., Klein, D.R. \& Shaver, G.R. 1994. Vertebrate herbivores and northern plant communities: reciprocal influences and responses. - Oikos 71: 193-206.

Kärenlampi, L., Tammisola, J. \& Hurme, H. 1975. Weight increase of some lichens as related to carbon dioxide increase and thallus moisture. In: Wielgolaski, F.E. (ed.) Fennoscandian tundra ecosystems, 1. Plants and microorganisms, pp. 135137. - Springer, Berlin.

Klein, D.R. 1982. Fire, lichens and caribou. - J. Range Man- age. 35: 390-395.

Klein, D.R. 1987. Vegetation recovery pattern following overgrazing by reindeer on St. Matthew Island. - J. Range Manage. 40: 336-338.

Königsson, L.K. 1986. The Fjällnäs project: Natural and cultural components in landscape formation. In Nordic late quarternary biology and ecology. - Striae 24: 177-186.

Kudo, G. 1993. Relationship between flower time and fruit set of the entomophilous alpine shrub Rhododendron aureum (Ericaceae) inhabiting snow patches. - Am. J. Bot. 80: 1300-1304.

Kuhmunen, N. 1974. Praktisk renvård. - Gällivare.

Kullman, L. 1979. Change and stability in the altidude of the birch tree-limit in the Southern Swedish Scandes 1915-1975. - Acta Phytogeogr. Suec. 65: 1-128.

Kullman,L. 1989. RenbeteseffekterpåSånfjället. -Rapport 3574, Naturvårdsverket, Solna.

Kullman, L. 1998. Aktuella vegetations-förändringar i södra delen av fjällkedjan. In: Olsson, O., Rolén, M. \& Torp, E. (eds.) Hållbar utveckling och biologisk mångfald i fjällregionen, rapport 98:2, pp. 160-169. - Forskningsrådsnämnden, Stockholm.

Kumpula, J., Colpaer, A. \& Nieminen, M. 2000. Condition, potential recovery rate, and productivity of lichen (Cladina spp.) ranges in the Finnish reindeer management area. - Arctic 53: $152-160$.

Kuoljok, S. 1998. Samernas historia. - Samtinget, Gällivare.

Lantbruksstyrelsen. 1985. Rennäringen - siffror och diagram. -Lantbruksstyrelsens meddelande 1985: 2.

Lantmäteriverket. 1978. Vegetationskarta. — Gävle.

Larson, D.W.\& Kershaw, K.A. 1975. Studies on lichen-dominated systems. XI Lichen-heath and winter snow cover. - Can. J. Bot. 53: 621-626.

Larsson, B. 1999. Lars Levi Laestadius - hans liv ock verk \& den laestadianska väckelsen. - Artos, Skellefteå.

Laufer, B. 1917. The reindeer and its domestication. - Mem. Am. Anthropol. Ass. IV-2.

Lehtonen, J. \& Heikkinen, R.K. 1995. On the recovery of mountain birch after Epirrita damage in Finnish Lapland, with a particular emphasis on reindeer grazing. - Écoscience 2: 349-356.

Lindberg, P. 1970. Suorva-Ritsem-Kaitum. - Sveriges Natur 61: 155-161.

Linnaeus, C. 1737. Flora Lapponica. -Amsterdam 1738. Svensk översättning av Th. M. Fries i skrifter av Carl von Linné. Utg. Vetenskapsakademi I 1905.

Linnaeus, C. 1758. Systema Naturae, etc. 10th ed. Tom 1:67. Holmiae.

Linnaeus, C. 1889. Iter dalecarlicum. - Carl von Linnés ungdomsskrifter samlade av E. Ährling och efter hans död med statsunderstöd utgifna af Vetenskapsakademi Andra serien Stockholm.

Linnaeus, C. 1913. Iter Lapponicum. Andra upplagan med bilagor och noter ombesör jda av Th. M. Fries. - Skrifter av Carl von Linné utg. av Vetenskapsakademi 5. Uppsala.

Ljungner, E. 1948. Kölen och Skanderna. - Svensk Geografisk Årsbok 24: 197-198.

Lönnberg, E. 1909. Om renarna och deras lefnadsvanor. - Attachment to: Förhandlingarna inför skiljedomstolen af 1909 i renbetesfrågan, Avdelning 1, Svensk inlaga no. 3, Uppsala.

Lundh, N.G. 1998. Vegetationsförändringar i det härjedalska 
fjällandskapet under åren 1750-1949. - FFI Forum 1998:2 Fjällforskningsinstitutet, Mitthögskolan, Östersund.

Lundin, L. 2003. Humiditet under vegetationsperioden m.m. Hemsida Inst. för skoglig marklära, SLU, Uppsala.

Lundmark, L. 1982. Uppbörd, utarmning, utveckling. Det samiska fångstsamhällets övergång till rennomadism i Lule lappmark. - Arkiv avhandlingsserie 14. Lund.

Lundmark, L. 1998. Så länge vi har marker. Samerna och staten under sexhundra år. - Rabén Prisma, Stockholm.

Magnus, O. 1539. Carta marina et descriptis septentrionalium terrarium ac mirabilium nerum in eis contentrarum. - Phototypice edita. Malmö 1949.

Magnus, O. 1555. Historia de gentibus septentrionalibus. - Historia om de nordiska folken. - Malmö 1982.

Manker, E. 1947. De svenska fjällapparna. - Svenska turistföreningens förlag, Stockholm, pp. 103-104.

Manseau, M., Huot, J. \& Crête, M. 1996. Effects of summer grazing by caribou on composition and productivity of vegetation: community and landscape level. - J. Ecol. 84: 503-513.

Marklund, B. 2004. Några närings- och sociala frågor hos skogssamerna 1650-1800. In: Lantto, P. \& Peter Sköld, P. (eds.) Befolkning och bosättning i norr. Etnicitet, Identitet och gränser i historiens sken. - Skrifter utgivna av Centrum för samisk forskning 1, Umeå 2004.

McKendrick, J.D. et al. 1980. Some effects of mammalian herbivores and fertilization on tundra soils and vegetation. - Arctic Alp. Res. 12: 565-578.

Milchunas, D.G., Sala, O.E. \& Laurenroth, W.K. 1988. A generalized model of the effects of grazing by large herbivores on grassland community structure. - Am. Nat. 132: 87-106.

Miller, D.R. 1976. Biology of the Kaminuriak population of barrenground caribou, Part 3. Taiga winter range relationships and diet. - Canadian Wildlife Service, Report Series 36: 1-41.

Moen, J. \& Oksanen, L. 1998. Long-term exclusion of folivorous mammals in two arctic-alpine plant communities: a test of the hypothesis of exploitation ecosystems. - Oikos 82: 333-346.

Moen, J., Gardfjell, H., Oksanen, L., Ericson, L. \& Ekerholm, P. 1993. Grazing by food-limited microtine rodents on a productive experimental plant community: does the "green desert" exist? - Oikos 68: 401-413.

Moren,A-S. \& Perttu, K.L. 1994. Regional temperature and radiation indices and their adjustment to horizontal and inclined forest land. - Stud. For. Suec. 1994: 1-19.

Mulder, C.P.H. 1999. Vertebrate herbivores and plants in the Arcic and subarctic: effects on individuals, populations, communities and ecosystems. - Persp. Plant Ecol. Evol. Syst. 2: 29-55.

Mulder, C.P.H. \& Ruess, R. 1998. Effects of herbivory on Arrowgrass: Interactions between geese, neighboring plants, and abiotic factors. - Ecol. Monogr. 68: 275-293.

Nieminen, M. 1980. Nutritional and seasonal effects on the haematology and blood chemistry in reindeer (Rangifer tarandus tarandus L.). - Comp. Biochem. Physiol. 66A: 399-413.

Nilsson, R. 2004. Av rovdjur dödade renar. Tabeller. - Sametinget, Kiruna.

Nordhagen, R. 1943. Sikkilsdalen og Norges fjellbeiter. - Bergen.

Nordkvist, M. 1980. Status of Rangifer in Sweden. In: Reimers, E., Gaare,E. \& Skjerneberg (eds.) Proceedings of 2nd international reindeer/Caribou symposium. - Røros, Norge.
Økland, R.H. 1990. A phytoecological study of the mire northern Kisselbermosen southeast Norway II. Identification of gradients by detrended canonical correspondence analysis. - Nord. J. Bot. 10: 79-108.

Oksanen, L. 1992. Renproblemet inom den svenska fjällvärlden i ekologiskt och historiskt perspektiv. In: Nyman, L. \& Jennersten, O. (eds.) - Renbeteskonferens WWF 1992 , Stockholm.

Oksanen, L. 1998. Naturförhållanden och dynamik inom den fennoskandiska fjäll- och tundravärlden. In: Olsson, O., Rolén, M. \& Torp, E. (eds.) Hållbar utveckling och biologisk mångfald i fjällregionen, rapport 98:2, pp. 184-198. - Forskningsrådsnämnden, Stockholm.

Oksanen, L. \& Virtanen, R. 1995. Topographic, altitudinal and regional patterns in continental and suboceanicheath vegetation of northern Fennoscandia. - Acta Bot. Fenn. 153: 1-80.

Olff, H. \& Ritchie, M.E. 1998. Effects of herbivores on grassland plant diversity. - Trends Ecol. Evol. 13: 261-265.

Olofsson, J. 2001. Long term effects of herbivory on tundra Ecosystems. - Doctoral thesis, Umeå University, Umeå.

Olofsson, J., Kitti, H., Rautiainen, P., Stark, S. \& Oksanen, L. 2001. Effects of summer grazing by reindeer on composition of vegetation productivity and nitrogen cycling. - Ecography 24: 13-24.

Olofsson, J., Hulme, P.E., Oksanen, L. \& Suominen, O. 2004. Importance of large and small mammalian herbivores for the plant community structure in the forest tundra ecotone. - Oikos 106: 324-334.

Olofsson, J., Moen, J. \& Oksanen, L. 2002. Effects of herbivory on competition intensity in two arctic-alpine tundra communities with different productivity. - Oikos 96: 265-272.

Olofsson, J., Stark, S. \& Oksanen, L. 2004. Reindeer influence on ecosystem processes in the tundra. - Oikos 105: 386-396.

Orlóci, L. 1978. Multivariate analysis in vegetation research. 2nd. ed. 451 pp. - Kluwer, The Hague.

Ottar, O. 820. In: King Alfred's English orosius; Ed. Janet Bately for the Early English text society 1980. - London.

Påhlsson, L. (ed.) 1998. Vegetationstyper i Norden. - Tema Nord 1998: 510. Köbenhavn.

Paine, R. 1972. The herd management of lapp reindeer pastoralist. - J. Asian African Stud. 7: 76-87.

Palo, T. 1981. Renbetning på kalfjäll under snösmältningsperioden. In: Eriksson, O., Palo, T. \& Söderström, L. Renbetning vintertid. - Växtekol. Stud. 13. Uppsala.

Pettersson, A. 1866. Lappland dess natur och folk. - Stockholm. $62 \mathrm{pp}$.

Polo, M. 1967. Marco Polos resor i Asien 1271-1295. - Stockholm.

Pyšek, P. 1997. Clonality and plant invasions: can a trait make a difference? In: de Kroon, H. \& van Groenendael, J. (eds.) The ecology and evolution of clonal plants, pp. 405-427. Bakhuys, Leiden.

Raab, B. \& Vedin, H. (eds.) 1995. - Sveriges Nationalatlas Volym: Klimat, sjöar och vattendrag. Stockholm.

Rafstedt, T. 1987. Vegetationskarta över norra Härjedalens skogsland och lågfjäll Sånfjället, Vemdalsfjällen, Klövsjöfjällen. - Naturvårdsverket, Stockholm.

Rehbinder, C. \& Nikander, S. 1999. Ren och rensjukdomar. Studentlitteratur, Lund.

Reimers, E. 1989. Villreinens verden. — Århus. 
Reindeer husbandry act 1971. - Rennäringslagen, SFS 1971: 437. Stockholm.

Renbeteskommissionen af år 1907. 1909. - Stockholm.

Renbeteskommissionen af år 1909 handlingar. 1912. - Helsingfors.

Renbeteskommissionen af år 1913 handlingar. 1913. - Helsingfors.

Renbeteskommissionen år 1906. 1913. - Stockholm.

Renman, G. 1989. Barmarkskörning i fjällen. Effekter av körning med terränghjulingar på mark och vegetation. - SNVRapport 3598. Naturvårdsverket, Solna.

Rheen, S. 1671 (1983). En kortt relation om lapparnes lefwarne och sedtrer, wijd -skiepellser, samt i många stycken grafwa wildfarelser. In: Berättelser om samerna i 1600-talets Sverige. - Kungl. Skytteanska samfundets handlingar. Nr 27. Umeå. 1983.

Roman, A. 1818. Betättelserom Norrbotten och dess Lappmarker. - Stockholm. 133 pp.

Rudbeck, O. d.ä. 1702. Campus Elysii. Vol. 1-2. - Uppsala.

Rudbeck, O. d.y. 1701. Nora samolad sive Laponia illustrata. Vol. 1. Uppsala.

Rudbeck, O.d.y. 1734. In: Acta literaria et scientiaricum Sveciae.

Rune, O. 1953. Plant life on serpentines and related rocks in the north of Sweden. - Acta Phytogeogr. Suec. 31.

Ruong, J. 1945. Studier i lapsk kultur i Pite lappmark och angränsande områden. - Svenska landsmål och svenskt folkliv 1943-1944, $182 \mathrm{pp}$.

Ruong, I. 1964. Jåhkåkaska sameby. In: Svenska landsmål och Svenskt folkliv. -Uppsala.

Ruong, I. 1982. Samerna i historien och framtiden. -Stockholm.

SAS Institute, 2001. SAS 8.02 forWindows. - SAS Institute Inc., Cary, North Carolina.

Schefferus, J. 1673. Lapponia. Frankfurt am Main. In: Manker, E. (ed.) Lapponia, Svensk version. -- Uppsala 1956.

Schmidt, J.W. 1801. Resa genom Hälsingland och Härjedalen år 1799. Luejie förlag 1992. Orginalutg, Hamburg.

Selander, S. 1950. Floristic phytogeography of southwestern Lule Lappmark (Swedish Lapland). I, II. - Acta Phytogeogr. Suecica 27, 28.

Selinge, K-G. 1982. Comments on economic change and the prehistoric fur trade in Northern Sweden. The relevance of a Canadian model. - Norw. Archaeol. Rev. 15: 115-123.

Shannon, C.E. 1948. A mathematical theory of communication. - The Bell System Techn. J. 27: 379-423.

Siivonen,L. 1975. New results on the history and taxonomy of the mountain, forest, and domestic reindeer in northern Europe. Proc. 1st Int. Reindeer and Caribou Symp., Fairbanks 1972, pp. 33-40, - Univ. of Alaska, Fairbanks.

Sjörs, H. 1956. Nordisk växtgeografi. - Bonniers, Stockholm.

Sjörs, H. 1971. Ekologisk botanik. - Almqvist \& Wiksell, Stockholm.

Sjörs, H. 1990. Divergent successions in mires, a comparative study. - Aquilo Ser. Bot. 28: 67-77.

Sjörs, H. 1999. The background: Geology, climate and zonation. In: Rydin, H., Snoeijs, P. \& Diekmann, M. (eds.) Swedish plant geography. - Acta Phytogeogr. Suec. 84.

Skjenneberg, S. \& Slagsvold, L. 1968. Reindriften og dens naturgrundlag. - Oslo.
Skogland, T. 1994. Villrein fra urinvåner vill miljöbarometer. Drammen.

Sköld,P. 1992. Samiskbosättning i Gällivare 1550-1750 - Center för Arktisk Kulturforskning. Umeå University. Rapport nr $22,189 \mathrm{pp}$.

Skuncke, F. 1958. Renbeten och deras gradering. - Uppsala.

Skuncke, F. 1973. Renen i urtid och nutid. - Stockholm.

Smith, H. 1920. Vegetationen och dess utvecklingshistoria i det centralsvenska högfjällsområdet. - Uppsala.

Statistics Sweden. 1999. Reindeer husbandry in Sweden. Halmstad.

Steckzein, B. 1964. Birkarlar och lappar. En studie i bierkarlaväsendets, lappbefolkningens och skinnfeodalens historia. - KVA. Historiska serien 9. Stockholm.

Stiling, P.D. 1996. Ecology-theories and applications. - Prentice Hall, London.

Stöckling, J. \& Bäumler, E. 1996. Establishment from seeds and clonal growth strategies on a glacier foreland. - J. Veg. Sci. 7: 45-56.

Suominen, O. \& Olofsson, J. 2000. Impacts of semi-domesticated reindeer on structure of tundra and forest communities in Fennoscandia: a review. - Ann. Zool. Fenn. 37: 233-249.

Suominen, O., Banell, K. \& Bergström, R. 1999. Moose, trees, and ground-living invertebrates: indirect interactions in Swedish pine forests. - Oikos 84: 215-226.

Svensk rennäring 1999. Svenska samemas riksförbund. - Jordbruksverket, Sveriges Landbruksuniversitet \& Statistiska Centralbyrån, Halmstad.

Syroechkovskii, E.E. 1984. Overview of the problem of wild reindeer in Soviet Union. In: Syroechkovskii, E.E. (ed.) Wild Reindeer of the Soviet Union, pp. 6-44. - Amerind Publ., New Delhi.

Tegengren, H. 1952. En utdöd lappkulturi Kemi lappmark. - Acta Academiae Aloensis, Humaniora 19: 4.

Tengwall, T.A. 1920. Die Vegetation des Sarekgebietes. - Uppsala.

Tengwall, T.Å. 1924. Die Gefässpflanzen des Sarekgebietes. Stockholm.

Tengwall, T.Å. 1928. Renlavamas tillväxt och biologi i Tome och Lule lappmarker. - Svensk Bot. Tidskr. 22: 18-32.

Tenow, O. 1972. The outbreaks of Oporina autumnata Bkh. and Operophthera spp. in the Scandinavian mountain chain and northern Finland 1862-1968. - Zool. Bidrag Suppl. 2: 1-107.

ter Braak, C.J.F. \& Šmilauer, P. 1998. CANOCO reference manual and users guide to CANOCO for Windows: Software for canonical community ordination (v.4) - Microcomputer Power, Ithaca.

Tuhkanen, S. 1980. Climatic parameters and indices in plant geography. - Acta Phytogeogr. Suec. 67: 1-110.

Turi, J. 1910. Muittalus samid birra. En bok om samernas liv. Samiska med dansk översättning. - Köpenhamn.

Uggla, E. 1958. Skogsbrandfält in Muddus Nationalpark. - Acta Phytogeographica Suecica 41.

Vainshtein, S. 1980. Nomads of South Siberia. The pastoral economics of Tuva. Cambridge studies of social anthropology 25. - Cambridge University Press, Cambridge.

van den Brink, P. 2000. Erosionsmätningar i hedvegetation i fjällområdet. - Fjälfforskningsinstitutet Forum 2000: 2.

Väre, H., Ohtonen, R. \& Oksanen, J. 1995. Effects of reindeer 
grazing on understory vegetation in dry Pinus sylvestris forests. - J. Veg. Sci. 6: 523-530.

Vibe, C. 1967. Arctic animals in relation to climatic fluctuations. - Meddelanden från Grönland 170: 5.

Vibe, C. 1982. Mikro-istider. In: NaturensVerden 9. - Köbenhavn.

Wahlenberg, G. 1804. Geografisk och ekonomisk beskrifning om Kemi lappmark i Vesterbottens höfdingdöme. Stockholm.

Wahlenberg, G. 1812. Flora Lapponica. - Berlin, 550 pp.

Wahlenberg, G. 1824-26. Flora Svecica. Pars I-II. - Uppsaliae.

Wahlenberg, G. 1830. Svensk botanik. - Stockholm.

Wallin, J.E. \& Aronsson, Å. 1998. Mittåkläppen-markanvändning och vegetationsförändringar undertvå århundraden. In: Anttila, S. \& Vikman, P.Å. (eds.) Forskning och förvaltning för hållbar utveckling i landets fjällområden. - Fjällforskningsinstitutet Östersund, Rapport 1998, 3 pp.

Wallsten, P. 1988. Rekreation i Rogen - tillämpning av en planeringsmetod för friluftsliv. - Universitetet $\mathrm{i}$ Trondheim.

Warenberg, K. 1977. Vegetation och renbete inom Ottfjällets renfarm - A study of the vegetation and of reindeer grazing habits on the Ottfjäll reindeer range. - Östersund.

Warenberg, K., Danell, Ö., Gaare, E. \& Nieminen, M. 1997. Flora i renbetesland. - Landbruksforlaget, Stockholm.

Wegener, C. \& Odasz, A.M. 1997. Effects of laboratory simulated grazing on biomass of the perennial Arctic grass Dupontia fisheri from Svalbard: evidence of overcompensation. Oikos 79: 496-502.

Weih, M. \& Karlsson, P.S. 1999. The nitrogen economy of mountain birch seedlings: implications for winter survival. - J. Ecol. 87: 211-219.

White, R.G., Bunnell, F.L., Gaare, E., Skogland, T. \& Hubert, T. 1981. Ungulates on Arctic ranges. In: Bliss, L.C., Cragg, J.B., Heal, D.W. \& Moore, J.J. (eds.) Tundra Ecosystems: A comparative analysis, pp. 397-483. - Cambridge University Press, Cambridge.

Wiklund, K.B. 1919. Om renskötselns uppkomst. - Ymer 1918, H3: 249-273. Stockholm.

Wistrand, G. 1962. Studier i Pite Lappmarks kärlväxtflora, med särskild hänsyn till skogslandet och de isolerade fjällen. -Acta Phytogeogr. Suecica 45.

Zackrisson, J. 1976. Lapps and Scandinavians. Archaeological finds from Northern Sweden. Early Nordland 10. - Kungl. Vitterhets, Historie och Antikvitets Akademien. Stockholm.

Zackrisson, J. 1984. De samiska metalldepåerna år 1000-1350. The Saami metal deposits a.d. 1000-1350. - Archaeology and Environment 3. Umeå.

Zackrisson, J. 1992. Sápmi 8/92. - SSR:s kansli. Umeå.

Zetterstedt, J.W. 1822. Resa genom Sveriges och Norriges Lappmarker, förrättad år 1821. - Lund.

Zetterstedt, J.W. 1833. Resa genom Umeå lappmarker i Vesterbottens län, förrättad år 1832. - Örebro.

Zetterstedt, J.W. 1822. Resa genom Sveriges och Norriges Lappmarker, förrättad år 1821. - Lund.

Zetterstedt, J.W. 1833. Resa genom Umeå lappmarker i Vesterbottens län, förrättad år 1832. - Örebro.

Zimov, S.A., Chuprynin, V.I., Oreshko, A.P., Chapin, F.S. III, Reynolds, J.F. \& Chapin, M.C. 1995. Steppe-tundra transition: A herbivore-driven biome shift at the end of the pleistocene. - Am. Nat. 146: 765-794.

\section{Other publications used}

Anon. 2002. The Saami Parliament. - Luleå.

Ahti, T., Hämet-Ahti, L. \& Jalas, J. 1968 Vegetation zones and their sections in northwestern Europe. - Ann. Bot. Fenn. 5: 169-211.

Berglund, B., Helmfrid, S. \& Hyenstrand, Å. 1994. Tiotusen år i Sverige. In: Helmfrid, S. (ed.) Sveriges Nationalatlas. - Bra Böcker, Malmö.

Bergman, S., Kübler, L. \& Martinsson, O. 2000. Regionala geologiska och geofysiska kartor över norra Norrbottenslän: Berggrundskarta. - Sveriges Geologiska Undersökning Ba 56:1.

Bernes, C. 1996. Arktisk miljö i Norden - orörd, exploaterad, förorenad? - Nordiska ministerrådet, Köpenhamn och Naturvårdsverket, Stockholm. Nord 1996: 21 Monitor 15.

Hallingbäck, T. \& Holmåsen, I. 1981. Mossor - En fälthandbok. - Interpublishing AB, Stockholm.

Helle, T. 1981. Studies on wild forest reindeer (Rangifer tarandus fennicus Lönn.) and semi-domestic reindeer (Rangifer tarandus tarandus L.) in Finland. - Acta Univ. Oul. A 107. 1980. Biol 12.

Hjelmqvist, S. 1964. Berggrundskarta över Kopparbergs län. Sveriges Geologiska Undersökning, Ca no. 40.

Karlsson, L. 1974. Turistslitaget i nedre Rapadalen, Sareks nationalpark. - Medd. Växtbiol. Inst. 1974: 7.

Korhonen, O. 1976. Linguistic and cultural diversity among the saamis and the development of standard saamish. - Int. J. Sociol. Language 10.

Kulling, O. 1963. Berggrundskarta över Norrbottensfjällens norra del. - Sveriges Geologiska Undersökning, Ba no. 19.

Lanntto, P. \& Sköld, P. (eds.) 2004. Befolkning och bosättning i norr. Etnicitet, identitet och gränser i historiens sken. Umeå.

Lundqvist, R. 2002. Fulufjället nationalpark i Dalafjällen. - Naturvårdsverket, Stockholm.

Moberg, R. \& Holmåsen, I. 1982. Lavar - En fälthandbok. Interpublishing $\mathrm{AB}$, Stockholm.

Nilsson, Ö. 1991. Nordisk fjällflora. - Bonnier, Stockholm.

Reimers, E. 1972. Growth in domestic and wild reindeer in Norway. - J. Wildl. Manage. 36: 612-619.

Reimers, E. 1983. Reproduction in wild Reindeer in Norway. Can. J. Zool. 61: 211-217.

Rune, O. 1965. The mountain regions of Lappland. In: The plant cover of Sweden. - Acta Phytogeogr. Suec. 50.

Ruong, I. 1937. Fjällapparna i Jukkasjärvi socken. - Geographica 3. Uppsala.

Sundegård, P.H., Gorbatsche, R. \& Kronfält, K-A. 1984. Kartaöver berggrunden i Jämtlands län. Ser Ca no 52. Sheet 1. - Liber Kartor, Stockholm. 


\section{Appendix I. Recorded species.}

\begin{tabular}{|c|c|c|c|c|c|c|c|c|c|}
\hline \multirow{2}{*}{$\begin{array}{l}\text { Birch forest type with lichens } \\
\text { Species/taxa and author }\end{array}$} & \multirow{2}{*}{$\begin{array}{l}\text { Swedish } \\
\text { common } \\
\text { name }\end{array}$} & \multicolumn{4}{|c|}{ Tavvavuoma } & \multicolumn{4}{|c|}{ Fulufjället } \\
\hline & & $\mathrm{C} 95$ & C99 & $\mathrm{O} 95$ & O99 & C96 & C99 & O96 & O99 \\
\hline \multicolumn{10}{|l|}{ Vascular plants } \\
\hline Antennaria spp. & kattfot & 1 & - & - & - & - & - & - & - \\
\hline Anthoxanthum odoratum L. & vårbrodd & - & 1 & - & - & - & - & - & - \\
\hline Arctostaphylos al pinus (L.) Sprengel & ripbär & - & - & 1 & - & - & - & 1 & 1 \\
\hline Betula nana $\mathrm{L}$. & dvärgbjörk & 1 & 1 & 1 & 1 & 1 & 1 & 1 & 1 \\
\hline Betula pubescens ssp. czerepanovii N. I. Orlova & fjällbjörk & 1 & - & 1 & - & 1 & 1 & 1 & 1 \\
\hline Calamagrostis lapponica (Wahlenb.) Hartm. & lapprör & - & - & - & 1 & - & - & - & - \\
\hline Calluna vulgaris (L.) Hull & ljung & - & - & - & 1 & 1 & 1 & 1 & 1 \\
\hline Deschampsiaflexuosa (L.) Trin. & kruståtel & 1 & 1 & 1 & 1 & 1 & 1 & 1 & 1 \\
\hline Empetrum hermaphroditum Hagerup & kråkbär & 1 & 1 & 1 & 1 & 1 & 1 & 1 & 1 \\
\hline Festuca ovina $\mathrm{L}$. & fårsvingel & 1 & 1 & 1 & 1 & - & - & - & - \\
\hline Hieracium spp. & fibbla & - & 1 & - & - & - & - & - & - \\
\hline Juncus trifidus L. & klynnetåg & - & 1 & 1 & 1 & - & - & - & - \\
\hline Juniperus communis $\mathrm{L}$. & en & 1 & - & 1 & - & - & - & - & - \\
\hline Linnaea borealis $\mathrm{L}$. & linnea & 1 & 1 & 1 & 1 & - & - & - & - \\
\hline Lycopodium alpinum $\mathrm{L}$. & fjällummer & - & 1 & 1 & 1 & - & - & - & - \\
\hline L. annotinum $\mathrm{L}$. & revlummer & - & - & - & 1 & - & - & - & - \\
\hline L. clavatum $\mathrm{L}$. & mattlummer & - & - & 1 & - & - & - & - & - \\
\hline L. complanatum $\mathrm{L}$. & plattlummer & - & 1 & - & 1 & - & - & - & - \\
\hline Phleum alpinum $\mathrm{L}$. & fjälltimotej & 1 & - & 1 & - & - & - & - & - \\
\hline Phyllodoce caerulea (L.) Bab. & lappljung & 1 & 1 & 1 & - & - & - & - & - \\
\hline Salix glauca L. & ripvide & 1 & 1 & 1 & 1 & - & - & - & - \\
\hline Solidago virgaurea $\mathrm{L}$. & gullris & 1 & 1 & 1 & 1 & - & - & - & - \\
\hline Trientalis europaea $\mathrm{L}$. & skogsstjäma & 1 & 1 & 1 & 1 & - & - & 1 & 1 \\
\hline Vaccinium myrtillus $\mathrm{L}$. & blåbär & 1 & 1 & 1 & 1 & 1 & 1 & 1 & 1 \\
\hline V. uliginosum $\mathrm{L}$. & odon & 1 & 1 & 1 & 1 & 1 & 1 & 1 & 1 \\
\hline V. vitis-idaea $\mathrm{L}$. & lingon & 1 & 1 & 1 & 1 & 1 & 1 & 1 & 1 \\
\hline Other grasses & Övrigt gräs & - & 1 & - & - & - & - & - & - \\
\hline \multicolumn{10}{|l|}{ Lichens } \\
\hline Cetraria cucullata (Bell.) Ach. & strutlav & - & - & 1 & - & ـ & - & - & - \\
\hline C. ericetorum Opiz & smal islandslav & 1 & 1 & 1 & 1 & 1 & 1 & 1 & 1 \\
\hline C. islandica (L.) Ach. & islandslav & 1 & 1 & 1 & 1 & 1 & 1 & 1 & 1 \\
\hline C. nivalis (L.) Ach. & snölav & 1 & 1 & 1 & 1 & 1 & 1 & 1 & 1 \\
\hline Cladina arbuscula (Wallr.) Hale \& Culb. & gulvit renlav & 1 & 1 & 1 & 1 & 1 & 1 & 1 & 1 \\
\hline C. rangiferina $(\mathrm{L}$.$) Nyl.$ & grå renlav & 1 & 1 & 1 & 1 & 1 & 1 & 1 & 1 \\
\hline C. stellaris (Opiz) Brodo & fönsterlav & 1 & 1 & 1 & 1 & 1 & 1 & 1 & 1 \\
\hline Cladonia sul phurina (Michaux) Fr. & pöslav & 1 & 1 & 1 & 1 & 1 & 1 & 1 & 1 \\
\hline C. bellidiflora (Ach.) Schaerer & blombägarlav & 1 & 1 & 1 & 1 & 1 & 1 & 1 & 1 \\
\hline C. coccifera (L.) Willd. & kochenillav & 1 & 1 & 1 & 1 & 1 & 1 & 1 & 1 \\
\hline C. cornuta (L.) Hoffm. & syllav & 1 & 1 & 1 & 1 & 1 & 1 & 1 & 1 \\
\hline C. crispata (Ach.) Flotow & taggig bägarlav & 1 & - & 1 & 1 & - & - & - & - \\
\hline C. fimbriata (L.) Fr. & naggig bägarlav & 1 & 1 & 1 & 1 & 1 & - & - & - \\
\hline C. furcata (Huds.) Schrader & rislav & 1 & - & 1 & 1 & - & & - & - \\
\hline C. gracilis $(\mathrm{L}$.$) Willd.$ & stängellav & 1 & 1 & 1 & 1 & 1 & 1 & 1 & 1 \\
\hline C.squamosa (Scop.) Hoffm. & fnaslav & - & - & - & - & - & 1 & - & 1 \\
\hline C. uncialis (L.) Wigg. & pigglav & 1 & 1 & 1 & 1 & 1 & 1 & 1 & 1 \\
\hline Cladonia spp. & bägarlavar & 1 & 1 & 1 & 1 & 1 & 1 & 1 & 1 \\
\hline Icmadophila ericetorum (L.) Zahlbr. & vitmosslav & 1 & 1 & 1 & - & - & - & - & - \\
\hline Nephroma arcticum (L.) Torss. & norrlandslav & 1 & 1 & 1 & 1 & - & - & - & - \\
\hline Ochrolechia frigida (Swartz) Lynge & nordlig örnlav & - & 1 & - & 1 & - & - & . & - \\
\hline Peltigera aphthosa (L.) Willd. & torsklav & - & 1 & 1 & 1 & - & - & - & - \\
\hline P. canina (L.) Willd. & filtlav & - & - & - & 1 & - & - & - & - \\
\hline Pertusaria dactylina (Ach.) Nyl. & fingerlik porlav & - & 1 & - & - & - & - & - & - \\
\hline Solorina crocea (L.) Ach. & saff ranslav & - & - & 1 & - & - & - & - & - \\
\hline Stereocaulon paschale (L.) Hoffm. & påskrislav & 1 & 1 & 1 & 1 & 1 & 1 & - & - \\
\hline Other lichens & Övriga lavar & 1 & 1 & 1 & 1 & 1 & 1 & 1 & 1 \\
\hline \multicolumn{10}{|l|}{ Mosses } \\
\hline Dicranum scoparium Hedw. & kvastmossa & 1 & 1 & 1 & 1 & 1 & 1 & 1 & 1 \\
\hline Hepaticae & Levermossa & 1 & 1 & 1 & 1 & 1 & 1 & 1 & 1 \\
\hline Hylocomium splendens (Hedw.) Schimp. & husmossa & 1 & 1 & 1 & 1 & 1 & 1 & 1 & 1 \\
\hline Paludella squarrosa (Hedw.) Brid. & piprensarmossa & 1 & - & 1 & - & - & - & . & - \\
\hline Pleurozium schreberi (Brid.) Mitt. & väggmossa & 1 & 1 & 1 & 1 & 1 & 1 & 1 & 1 \\
\hline Polytrichum juniperinum Hedw. & enbjörnmossa & - & 1 & - & 1 & - & - & - & - \\
\hline P. piliferum Hedw. & hårbjörnmossa & 1 & - & 1 & 1 & - & - & 1 & - \\
\hline Polytrichum spp. & bjömmossor & - & 1 & - & 1 & - & 1 & - & 1 \\
\hline Ptilidium ciliare (L.) Hampe & franslevermossa & - & - & - & 1 & - & - & - & - \\
\hline Other mosses & Övrig mossa & 1 & 1 & 1 & 1 & - & - & - & - \\
\hline
\end{tabular}




\begin{tabular}{|c|c|c|c|c|c|c|c|c|c|c|c|c|c|c|c|c|c|}
\hline \multirow{3}{*}{$\begin{array}{l}\text { Birch forest type with mosses } \\
\text { Species/taxa and author } \\
\text { Andromeda polifolia } \mathrm{L} \text {. }\end{array}$} & \multirow{3}{*}{$\begin{array}{l}\begin{array}{l}\text { Swedish } \\
\text { common } \\
\text { name }\end{array} \\
\text { rosling }\end{array}$} & \multicolumn{4}{|c|}{ Tavavuoma } & \multicolumn{4}{|c|}{ Sonf jället } & \multirow{2}{*}{\multicolumn{4}{|c|}{$\begin{array}{l}\text { Långfjället } \\
\text { C95C98 O95 } 098\end{array}$}} & \multicolumn{4}{|c|}{ Fulufjället } \\
\hline & & \multicolumn{2}{|c|}{$\mathrm{C} 95 \mathrm{C} 98$} & \multicolumn{2}{|c|}{ O95 098} & \multicolumn{2}{|c|}{ C95 C98 } & \multicolumn{2}{|c|}{ O95 098} & & & & & & & 095 & 099 \\
\hline & & - & - & - & - & - & - & - & - & - & - & - & - & - & - & 1 & 1 \\
\hline Arctostaphylos al pinus (L.) Sprengel & ripbär & - & - & - & - & - & ـ & - & 1 & - & - & - & 1 & . & - & - & 1 \\
\hline Bartsia al pina $\mathrm{L}$. & svarthö & 1 & - & - & - & - & - & - & - & - & - & - & - & - & - & . & - \\
\hline Betula nana $\mathrm{L}$. & dvärgbjörk & 1 & 1 & 1 & 1 & 1 & 1 & 1 & 1 & 1 & 1 & 1 & 1 & 1 & 1 & 1 & 1 \\
\hline Betula pubescens ssp. czerepanovii N. I. Orlova & fjällbjörk & 1 & 1 & 1 & 1 & 1 & 1 & $\mathrm{I}$ & 1 & 1 & 1 & 1 & 1 & 1 & $\mathrm{I}$ & 1 & 1 \\
\hline Calamagrostis spp. & rör & - & 1 & - & 1 & - & - & - & - & - & - & - & - & - & - & - & - \\
\hline Calluna vulgaris (L.) Hull & ljung & - & - & - & - & - & - & - & - & 1 & 1 & 1 & 1 & 1 & 1 & 1 & 1 \\
\hline Carex spp. & starr & - & 1 & 1 & - & - & - & - & - & - & $=$ & - & - & - & - & - & - \\
\hline Deschampsiaflexuosa (L.) Trin. & kruståtel & 1 & 1 & 1 & 1 & 1 & 1 & 1 & 1 & 1 & 1 & 1 & 1 & 1 & 1 & 1 & 1 \\
\hline Empetrum hermaphroditum Hagerup & kråkbär & 1 & 1 & 1 & 1 & 1 & 1 & 1 & 1 & 1 & 1 & $\mathbb{1}$ & 1 & 1 & 1 & 1 & $\mathrm{l}$ \\
\hline Equisetum sylvaticum $\mathrm{L}$. & skogsfräken & - & 1 & - & - & - & - & - & - & - & - & - & - & - & - & - & - \\
\hline Eriophorum vaginatum $\mathrm{L}$. & tuvull & - & - & - & - & - & - & - & - & - & - & - & - & - & - & 1 & - \\
\hline Festuca ovina $\mathrm{L}$. & fårsvingel & - & 1 & 1 & 1 & - & - & - & - & - & 1 & - & 1 & - & - & - & - \\
\hline Hieracium spp. & fibbla & - & - & - & - & - & - & - & - & - & . & - & - & 1 & - & - & - \\
\hline Huperzia selago (L.) Bernh. ex Schrank \& Mart. & lopplummer & - & - & - & 1 & - & - & - & - & - & - & - & - & - & - & - & - \\
\hline Juniperus communis L. & en & 1 & 1 & 1 & 1 & 1 & 1 & 1 & 1 & 1 & 1 & 1 & 1 & 1 & 1 & 1 & 1. \\
\hline Linnaea borealis $\mathrm{L}$. & linnea & 1 & 1 & 1 & 1 & - & - & - & - & - & 1 & 1 & 1 & - & - & - & - \\
\hline Luzula pilosa (L.) Willd. & vårfryle & - & - & & - & - & - & - & - & 1 & 1 & 1 & 1 & 1 & 1 & 1 & 1 \\
\hline Lycopodium alpinum $\mathrm{L}$. & fjällummer & 1 & 1 & 1 & I & - & - & - & - & - & - & - & - & - & - & - & - \\
\hline L. annotinum L. & revlummer & I & 1 & 1 & 1 & - & - & - & - & 1 & 1 & 1 & 1 & . & - & - & - \\
\hline L. clavatum $\mathrm{L}$. & mattlummer & - & 1 & - & 1 & - & - & - & - & - & - & - & - & - & - & - & - \\
\hline L. complanatum $\mathrm{L}$. & plattlummer & - & 1 & - & - & - & - & - & - & - & - & - & - & - & - & - & - \\
\hline Melampyrum pratense $\mathrm{L}$. & ängskovall & - & - & - & - & - & - & - & - & 1 & 1 & 1 & 1 & 1 & 1 & I & 1 \\
\hline Molinia caerulea (L.) Moench & blătåtel & - & - & - & - & - & - & - & - & - & - & - & - & - & - & 1 & 1 \\
\hline Nardus stricta $\mathrm{L}$. & stagg & - & - & - & - & - & - & - & - & - & 1 & 1 & - & 1 & 1 & 1 & 1 \\
\hline Pedicularis lapponica $\mathrm{L}$. & lappspira & 1 & 1 & 1 & 1 & - & - & - & - & - & - & - & - & - & - & - & - \\
\hline Phyllodoce caerulea (L.) Bab. & lappljung & - & - & - & - & - & 1 & - & - & - & - & - & - & - & - & - & - \\
\hline Pinus sylvestris L. & tall & . & - & - & - & - & - & - & - & - & 1 & - & - & - & - & - & - \\
\hline Rubus chamaemorus $\mathrm{L}$. & hjortron & 1 & - & - & - & - & - & - & - & - & - & - & - & - & - & - & - \\
\hline Salix herbacea $\mathrm{L}$. & dvärgvide & 1 & - & - & - & - & - & - & - & - & - & - & & - & - & - & - \\
\hline Solidago virgaurea $\mathrm{L}$. & gullris & 1 & 1 & 1 & 1 & - & - & 1 & - & 1 & 1 & 1 & 1 & 1 & 1 & 1 & 1 \\
\hline Sorbus aucuparia L. & rönn & - & - & - & - & - & - & - & - & - & - & 1 & 1 & - & - & - & - \\
\hline Trientalis europaea $\mathrm{L}$. & skogsstjäma & 1 & 1 & 1 & 1 & 1 & 1 & 1 & 1 & 1 & 1 & 1 & 1 & 1 & 1 & 1 & 1 \\
\hline Vaccinium myrtillus L. & blåbär & 1 & 1 & 1 & 1 & 1 & 1 & 1 & 1 & 1 & 1 & 1 & 1 & 1 & I & 1 & 1 \\
\hline V. uliginosum $\mathrm{L}$. & odon & 1 & 1 & 1 & 1 & 1 & 1 & 1 & 1 & 1 & 1 & 1 & 1 & 1 & $\mathrm{l}$ & 1 & 1 \\
\hline V. vitis-idaea $\mathrm{L}$. & lingon & 1 & 1 & 1 & 1 & 1 & 1 & 1 & 1 & 1 & 1 & 1 & 1 & 1 & 1 & 1 & 1 \\
\hline
\end{tabular}

\section{Lichens}

Cetraria cucullata (Bell.) Ach.

C. ericetorum Opiz

C. islandica (L.) Ach.

C. nivalis (L.) Ach.

Cladina arbuscula (Wallr.) Hale \& Culb.

C. rangiferina $(\mathrm{L}.) \mathrm{Nyl}$.

C. stellaris (Opiz) Brodo

Cladonia sul phurina (Michaux) Fr.

C. bellidiflora (Ach.) Schaerer

C. coccifera $(\mathrm{L}$.) Willd.

C. cornuta (L.) Hoffm.

C. crispata (Ach.) Flotow

C. fimbriata (L.) Fr.

C. gracilis (L.) Willd

C. pyxidata (L.) Hoffm.

C. squamosa (Scop.) Hoffm.

C. uncialis (L.) Wigg.

Cladonia spp.

Icmadophila ericetorum (L.) Zahlbr.

Nephroma arcticum (L.) Torss.

Peltigera aphthosa (L.) Willd.

Stereocaulon paschale (L.) Hoffm.

Other lichens

\section{Mosses}

Dicranum scoparium Hedw.

Hepaticae

Hylocomium splendens (Hedw.) Schimp.

Paludella squarrosa (Hedw.) Brid.

Pleurozium schreberi (Brid.) Mitt.

Polytrichum juniperinum Hedw.

P. piliferum Hedw.

Polytrichum spp.

Ptilidium ciliare (L.) Hampe

Sphagnum spp.

Other mosses

strutlav

smal islandslav

islandslav

snölav

gulvit renlav

grå renlav

fönsterlav

pöslav

blombägarlav

kochenillav

syllav

taggig bägarlav

naggig bägarlav

stängellav

trattlav

fnaslav

pigglav

bägarlavar

vitmosslav

norrlandslav

torsklav

påskrislav

Övriga lavar

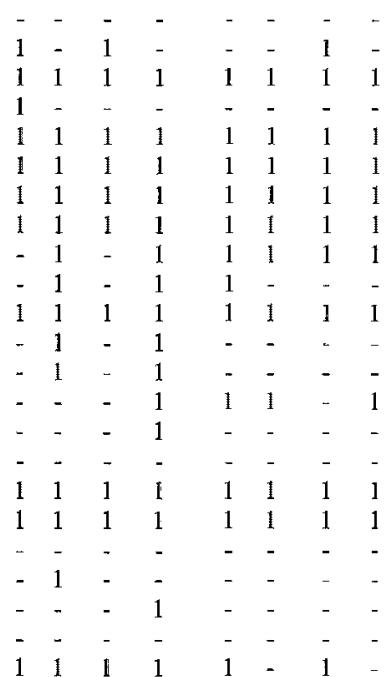

kvastmossa

Levermossor

husmossa

piprensarmossa

väggmossa

enbjörnmossa

hårbjörnmossa

björnmossor

franslevermossa

vitmossa

Övrig mossa

$\begin{array}{llllllll}1 & 1 & 1 & 1 & 1 & 1 & 1 & 1 \\ 1 & 1 & 1 & 1 & 1 & 1 & 1 & 1 \\ 1 & 1 & 1 & 1 & 1 & 1 & 1 & 1 \\ - & - & - & - & 1 & - & - & - \\ 1 & 1 & 1 & 1 & 1 & 1 & 1 & 1 \\ - & - & - & - & - & - & - & - \\ 1 & 1 & 1 & - & 1 & - & 1 & 1 \\ - & 1 & - & 1 & 1 & 1 & - & 1 \\ - & - & - & - & - & - & - & - \\ - & - & - & - & 1 & 1 & 1 & 1 \\ 1 & 1 & 1 & 1 & 1 & - & 1 & 1\end{array}$




\begin{tabular}{|c|c|c|c|c|c|c|c|c|c|}
\hline \multirow{2}{*}{$\begin{array}{l}\text { Dry heath } \\
\text { Species/taxa and author }\end{array}$} & \multirow[b]{2}{*}{$\begin{array}{l}\text { Swedish } \\
\text { common name }\end{array}$} & \multirow[b]{2}{*}{$\mathrm{C} 97$} & \multicolumn{3}{|c|}{ Tjuolma jaure } & \multicolumn{3}{|c|}{ Poullanvare } & \multirow[b]{2}{*}{ O99 } \\
\hline & & & $\mathrm{C} 99$ & $\mathrm{O} 97$ & O99 & C97 & C99 & O97 & \\
\hline Betula nana $\mathrm{L}$. & dvärgbjörk & 1 & 1 & 1 & 1 & 1 & 1 & 1 & 1 \\
\hline Betula pubescens ssp. czerepanovii N. I. Orlova & fjällbjörk & - & - & - & - & - & - & - & 1 \\
\hline Calamagrostis lapponica (Wahlenb.) Hartm. & lapprör & 1 & 1 & 1 & 1 & 1 & 1 & 1 & 1 \\
\hline Carex bigelowii Torr. Ex Schwein & styvstarr & 1 & 1 & 1 & 1 & - & - & - & - \\
\hline Cassiope hypnoides (L.) D.Don & mossljung & - & - & - & 1 & - & - & - & - \\
\hline Empetrum hermaphroditum Hagerup & kråkbär & 1 & 1 & 1 & - & 1 & 1 & 1 & 1 \\
\hline Festuca ovina $\mathrm{L}$. & fårsvingel & - & - & 1 & - & - & - & - & - \\
\hline Juncus trifidus $\mathrm{L}$. & klynnetåg & 1 & 1 & - & 1 & 1 & 1 & 1 & - \\
\hline Luzula multiflora ssp. frigida (Buchenau) V. I Krecz. & säterfryle & - & - & - & 1 & - & - & - & - \\
\hline L. spicata (L.) DC. & axfryle & 1 & - & - & - & - & - & - & - \\
\hline Pedicularis lapponica $\mathrm{L}$. & lappspira & - & - & 1 & - & - & - & - & - \\
\hline Phyllodoce caerulea (L.) Bab. & lappljung & 1 & 1 & 1 & 1 & - & - & - & - \\
\hline Vaccinium myrtillus $\mathrm{L}$. & blåbär & - & - & - & - & 1 & - & - & 1 \\
\hline V. uliginosum $\mathrm{L}$. & odon & 1 & 1 & 1 & - & 1 & 1 & 1 & 1 \\
\hline V. vitis-idaea $\mathrm{L}$. & lingon & 1 & 1 & 1 & 1 & 1 & 1 & 1 & 1 \\
\hline \multicolumn{10}{|l|}{ Lichens } \\
\hline Alectoria nigricans (Ach.) Nyl. & upprätt tagellav & 1 & 1 & 1 & 1 & 1 & 1 & 1 & 1 \\
\hline A. ochroleuca (Hoffm.) Massal. & fjälltagellav & 1 & - & - & - & - & 1 & - & - \\
\hline Cetraria cucullata (Bell.) Ach. & strutlav & 1 & 1 & 1 & 1 & 1 & 1 & 1 & 1 \\
\hline C. ericetorum Opiz & smal islandslav & 1 & 1 & 1 & 1 & 1 & 1 & 1 & 1 \\
\hline C. islandica (L.) Ach. & islandslav & 1 & 1 & - & 1 & 1 & 1 & 1 & 1 \\
\hline C. nivalis (L.) Ach. & snölav & 1 & 1 & 1 & 1 & 1 & 1 & 1 & 1 \\
\hline Cladina arbuscula (Wallr.) Hale \& Culb. & gulvit renlav & 1 & 1 & 1 & 1 & 1 & 1 & 1 & 1 \\
\hline C. rangiferina (L.) Nyl. & grå renlav & 1 & 1 & 1 & 1 & 1 & 1 & 1 & 1 \\
\hline C. stellaris (Opiz) Brodo & fönsterlav & 1 & 1 & 1 & 1 & 1 & 1 & 1 & 1 \\
\hline Cladonia amaurocraea & stor pigglav & - & - & - & - & - & - & 1 & - \\
\hline C. bellidiflora (Ach) Schaerer & blombägarlav & 1 & 1 & 1 & 1 & 1 & 1 & 1 & 1 \\
\hline C. coccifera $($ L.) Willd. & kochenillav & 1 & 1 & 1 & 1 & 1 & 1 & 1 & 1 \\
\hline C. cornuta (L.) Hoffm. & syllav & 1 & - & 1 & - & 1 & 1 & 1 & - \\
\hline C. crispata (Ach.) Flotow & taggig bägarlav & 1 & - & 1 & - & 1 & - & 1 & - \\
\hline C. fimbriata (L.) Fr. & naggig bägarlav & 1 & 1 & 1 & 1 & 1 & 1 & 1 & 1 \\
\hline C. gracilis (L.) Willd. & stängellav & 1 & 1 & 1 & 1 & 1 & 1 & 1 & 1 \\
\hline Cladonia sub furcata (Nyl.) Arn. & mossbägarlav & 1 & - & - & - & - & - & 1 & - \\
\hline C. uncialis (L.) Wigg. & pigglav & 1 & 1 & 1 & 1 & 1 & 1 & 1 & 1 \\
\hline Cladonia spp. & bägarlavar & 1 & 1 & 1 & 1 & 1 & 1 & 1 & 1 \\
\hline Icmadophila ericetorum (L.) Zahlbr. & vitmosslav & - & - & - & - & - & 1 & 1 & - \\
\hline Nephroma arcticum (L.) Torss. & norrlandslav & 1 & 1 & 1 & 1 & 1 & 1 & 1 & 1 \\
\hline Ochrolechia frigida (Swartz) Lynge & nordlig örnlav & 1 & 1 & 1 & 1 & 1 & 1 & 1 & 1 \\
\hline Peltigera canina (L.) Willd. & filtlav & - & - & & - & - & 1 & - & - \\
\hline P. scabrosa Th. Fr. & sträv filtlav & - & - & 1 & - & - & - & 1 & - \\
\hline Pertusaria dactylina (Ach.) Nyl. & fingerlik porlav & - & 1 & - & 1 & - & 1 & - & 1 \\
\hline Solorina crocea $($ L.) Ach. & saffranslav & 1 & - & 1 & 1 & - & 1 & - & - \\
\hline Sphaerophorus globosus (huds.) Vainio & korallav & - & - & 1 & 1 & - & - & - & - \\
\hline Stereocaulon paschale (L.) Hoffm. & påskrislav & 1 & 1 & 1 & 1 & 1 & 1 & 1 & 1 \\
\hline Thamnolia vermicularis (Swartz) Schaerer & masklav & 1 & 1 & 1 & - & - & - & - & - \\
\hline Other lichens & Övriga lavar & 1 & 1 & 1 & 1 & 1 & 1 & 1 & - \\
\hline \multicolumn{10}{|l|}{ Mosses } \\
\hline Dicranum scoparium Hedw. & kvastmossa & 1. & 1 & 1 & 1 & 1 & 1 & 1 & 1 \\
\hline Hepaticae & Levermossor & 1 & 1 & 1 & 1 & - & 1 & 1 & - \\
\hline Polytrichum juniperinum Hedw. & enbjörnmossa & 1 & - & 1 & - & 1 & 1 & 1 & 1 \\
\hline P. piliferum Hedw. & hårbjörnmossa & 1 & - & 1 & - & 1 & 1 & 1 & 1 \\
\hline Polytrichum spp. & björnmossor & - & 1 & - & 1 & - & 1 & - & 1 \\
\hline Ptilidium ciliare (L.) Hampe & franslevermossa & - & 1 & - & 1 & - & - & - & - \\
\hline Other mosses & Övrig mossa & - & 1 & 1 & - & 1 & - & 1 & - \\
\hline
\end{tabular}




\begin{tabular}{|c|c|c|c|c|c|}
\hline \multirow{2}{*}{$\begin{array}{l}\text { Grass heath } \\
\text { Species/taxa and author }\end{array}$} & \multirow{2}{*}{$\begin{array}{l}\text { Swedish } \\
\text { common } \\
\text { name }\end{array}$} & \multicolumn{3}{|c|}{ Långfjället } & \multirow[b]{2}{*}{098} \\
\hline & & $\mathrm{C} 95$ & C98 & O95 & \\
\hline Betula nana $\mathrm{L}$. & dvärgbjörk & - & - & 1 & 1 \\
\hline Callluna vulgaris (L.) Hull & ljung & 1 & 1 & - & - \\
\hline C. bigelowii Torr. Ex Schwein & styvstarr & 1 & 1 & 1 & 1 \\
\hline Cassiope hypnoides (L.) D.Don & mossljung & - & - & 1 & - \\
\hline Deschampsia flexuosa (L.) Trin. & kruståtel & 1 & 1 & 1 & 1 \\
\hline Empetrum hermaphroditum Hagerup & nordkråkbär & 1 & 1 & 1 & 1 \\
\hline Festuca ovina $\mathrm{L}$. & fårsvingel & 1 & - & 1 & - \\
\hline Hieracium L. sect. al pina (Griseb.) Gremli & fjällfibbla & - & - & - & 1 \\
\hline Hieracium spp. & övriga fibblor & 1 & 1 & 1 & 1 \\
\hline Juncus trifidus $\mathrm{L}$. & klynnetåg & 1 & 1 & 1 & 1 \\
\hline Juniperus communis L. & en & 1 & 1 & 1 & 1 \\
\hline Loiseleuria procumbens (L.) Desv. & krypljung & - & 1 & - & - \\
\hline Lycopodium procumbens $(\mathrm{L})$. & fjällummer & 1 & 1 & 1 & 1 \\
\hline Phyllodoce caerulea (L.) Bab. & lappljung & 1 & 1 & 1 & 1 \\
\hline Solidago virgaurea $\mathrm{L}$. & gullris & 1 & 1 & 1 & 1 \\
\hline Trientalis europaea $\mathrm{L}$. & skogsst järna & 1 & 1 & 1 & 1 \\
\hline Vaccinium myrtillus $\mathrm{L}$. & blåbär & 1 & 1 & 1 & 1 \\
\hline V. vitis-idaea $\mathrm{L}$. & lingon & 1 & 1 & 1 & 1 \\
\hline \multicolumn{6}{|l|}{ Lichens } \\
\hline Bryocaulon divergens (Ach.) Kämef. & spärrlav & - & - & - & 1 \\
\hline Cetraria cucullata (Bell.) Ach. & strutlav & - & 1 & 1 & 1 \\
\hline C. ericetorum Opiz & smal islandslav & 1 & 1 & 1 & 1 \\
\hline C. islandica (L.) Ach. & islandslav & 1 & 1 & 1 & 1 \\
\hline C. nivalis (L.) Ach. & snölav & 1 & 1 & 1 & 1 \\
\hline Cladina arbuscula (Wallr.) Hale \& Culb. & gulvit renlav & 1 & 1 & 1 & 1 \\
\hline C. rangiferina $(\mathrm{L}.) \mathrm{Nyl}$ & grå renlav & 1 & 1 & 1 & 1 \\
\hline C. stellaris (Opiz) Brodo & fönsterlav & 1 & 1 & 1 & 1 \\
\hline Cladonia sulphurina (Michaux) Fr. & pöslav & 1 & 1 & I & 1 \\
\hline C. bellidiflora (Ach.) Schaerer & blombägarlav & - & 1 & - & 1 \\
\hline C. coccifera $(\mathbf{L}$.) Willd. & kochenillav & - & 1 & - & 1 \\
\hline C.cornuta (L.) Hoffm. & syllav & 1 & 1 & 1 & 1 \\
\hline C. fimbriata (L.) Fr. & naggig bägarlav & - & 1 & - & 1 \\
\hline C. gracilis (L.) Willd. & stängellav & - & 1 & - & 1 \\
\hline C. unicialis (L.) Wigg. & pigglav & 1 & 1 & 1. & 1 \\
\hline Cladonia spp. & bägarlavar & 1 & 1 & 1 & 1 \\
\hline Icmadophila ericetorum (L.) Zahlbr. & vitmosslav & - & - & - & 1 \\
\hline Lepraria membranacea (Dickson) Vainio & mjöllav & 1 & - & 1 & - \\
\hline Ochrolechia frigida (Swartz) Lynge & nordlig örnlav & - & - & - & 1 \\
\hline Stereocaulon paschale (L.) Hoffm. & påskrislav & 1 & - & 1 & 1 \\
\hline Other lichens & Övriga lavar & 1 & 1 & 1 & 1 \\
\hline \multicolumn{6}{|l|}{ Mosses } \\
\hline Dicranum scoparium Hedw. & kvastmossa & 1 & 1 & 1 & 1 \\
\hline Hepaticae & Levermossa & 1 & 1 & 1 & - \\
\hline Pleurozium schreberi (Brid.) Mitt. & väggmossa & - & - & 1 & - \\
\hline Polytrichum piliferum Hedw. & hårbjörnmossa & 1 & 1 & 1 & 1 \\
\hline Polytrichum spp. & björnmossor & - & 1 & - & 1 \\
\hline Sphagnum spp. & vitmossa & - & 1 & - & 1 \\
\hline Other mosses & Övrig mossa & 1 & - & 1 & 1 \\
\hline
\end{tabular}




\begin{tabular}{|c|c|c|c|c|c|c|c|}
\hline Meadow with low herbs & $\begin{array}{l}\text { Swedish } \\
\text { common }\end{array}$ & & & & sem & & \\
\hline Species/taxa and author & name & & C95 & C99 & 095 & O99 & \\
\hline Agrostis mertensii Trin. & fjällven & & 1 & 1 & 1 & 1 & \\
\hline Antennaria spp. & kattfot & & - & 1 & 1 & 1 & \\
\hline Anthoxanthum odoratum $\mathrm{L}$. & vårbrodd & & 1 & 1 & 1 & 1 & \\
\hline Betula nana $\mathrm{L}$. & dvärgbjörk & & 1 & 1 & 1 & 1 & \\
\hline Bistorta vivipara (L.) Gray & ormrot & & 1 & 1 & 1 & 1 & \\
\hline Calamagrostis lapponica (Wahlenb.) Hartm. & lapprör & & 1 & 1 & 1 & 1 & \\
\hline Carex atrata $\mathrm{L}$ & svartstarr & & - & 1 & - & 1 & \\
\hline C. bigelowii Torr. ex Schwein & styvstarr & & 1 & 1 & 1 & 1 & \\
\hline C. canescens $\mathrm{L}$. & gråstarr & & 1 & 1 & 1 & 1 & \\
\hline C. lachenalii $\mathrm{L}$. & ripstarr & & 1 & 1 & 1 & 1 & \\
\hline Carex spp. & övrig starr & & 1 & 1 & 1 & 1 & \\
\hline Cassiope hypnoides (L.) D.Don & mossljung & & 1 & 1 & 1 & 1 & \\
\hline Cerastium fontanum ssp. fontanum Gartner & riparv & & - & 1 & - & 1 & \\
\hline Deschampsiaflexuosa (L.) Trin. & kruståtel & & 1 & 1 & 1 & 1 & \\
\hline Empetrum hermaphroditum Hagerup & nordkråkbär & & 1 & 1 & 1 & 1 & \\
\hline Equisetum arvense $\mathrm{L}$. & åkerfräken & & - & - & 1 & - & \\
\hline Festuca ovina $\mathrm{L}$. & fårsvingel & & 1 & 1 & 1. & 1 & \\
\hline Gentiana nivalis $\mathbf{L}$. & fjällgentiana & & - & - & 1 & - & \\
\hline Gnaphalium supinum $\mathrm{L}$. & fjällnoppa & & 1 & 1 & 1 & 1 & \\
\hline Hieracium spp. & övriga fibblor & & 1 & 1 & 1 & 1 & \\
\hline Huperzia selago (L.) Bemh. ex Schrank \& Mart. & lopplummer & & 1 & 1 & 1 & 1 & \\
\hline Juncus trifidus $\mathrm{L}$. & klynnetåg & & 1 & 1 & 1 & 1 & \\
\hline Loiseleuria procumbens (L.) Desv. & krypljung & & 1 & 1 & 1 & 1 & \\
\hline Luzula multiflora (Ehrh.) Lej. & ängsfryle & & 1 & 1 & 1 & 1 & \\
\hline L. spicata $(\mathrm{L}.) \mathrm{DC}$ & axfryle & & 1 & - & 1 & - & .. \\
\hline Lycopodium alpinum $\mathrm{L}$. & fjällummer & & 1 & - & 1 & 1 & \\
\hline L. annotinum $\mathrm{L}$. & revlummer & & - & 1 & - & 1 & \\
\hline L. clavatum $\mathrm{L}$. & mattlummer & & 1 & - & 1. & - & \\
\hline Pedicularis lapponica $\mathrm{L}$. & lappspira & & 1 & 1 & 1 & 1 & \\
\hline Petasites frigidus $\mathrm{L}$. & fjällskråp & & - & - & 1 & - & \\
\hline Phleum alpinum $\mathrm{L}$. & fjälltimotej & & 1 & 1 & 1 & 1 & \\
\hline Phyllodoce caerulea (L.) Bab. & lappljung & & 1 & 1 & 1 & 1 & \\
\hline Poa pratensis ssp. alpigena (Fr.) Hiitonen & nordgröe & & 1 & - & 1 & - & \\
\hline Ranunculus nivalis $\mathrm{L}$. & fjällsmörblomma & & - & - & 1 & - & \\
\hline Ranunculus spp. & övriga smörblommor & & 1 & - & 1 & 1 & \\
\hline Rhodiolarosea $\mathrm{L}$. & rosenrot & & - & - & 1 & 1 & \\
\hline Rubus chamaemorus $\mathrm{L}$. & hjortron & & 1 & 1 & 1 & 1 & \\
\hline Rumex acetosa $\mathrm{L}$. & ängssyra & & 1 & 1 & 1 & 1 & \\
\hline Rumexacetosa ssp. lapponicus (Hiitonen) Jalas & lappsyra & & 1 & - & 1 & - & \\
\hline Salix glauca L. & ripvide & & 1 & 1 & 1 & 1 & \\
\hline S. herbacea L. & dvärgvide & & 1 & 1 & 1 & 1 & \\
\hline Sibbaldia procumbens $\mathrm{L}$. & dvärgfingerört & & 1 & 1 & 1 & 1 & \\
\hline Solidago virgaurea $\mathrm{L}$. & gullris & & 1 & 1 & 1 & 1 & \\
\hline Taraxacum spp. F.H. Wigg & maskros & & - & - & 1 & 1 & \\
\hline Trientalis europaea $\mathrm{L}$. & skogsstjäma & & 1 & 1 & 1 & 1 & \\
\hline Trisetum spicatum (L.) K. Richter & fjällhavre & & - & 1 & - & 1 & \\
\hline Vaccinium myrtillus $\mathrm{L}$. & blåbär & & 1 & 1 & 1 & 1 & \\
\hline V. uliginosum $\mathrm{L}$. & odon & & $=$ & 1 & - & 1 & \\
\hline V. vitis-idaea $\mathrm{L}$ & lingon & & 1 & 1 & 1 & ] & \\
\hline Vahlodea atropur purea (Wahlenb.) Fr. ex Hartm. & lapptåtel & & 1 & 1 & 1 & 1 & \\
\hline Veronica al pina $\mathrm{L}$. & fjällveronika & & - & - & 1 & 1 & \\
\hline Viola biflora $\mathrm{L}$. & fjällviol & & + & - & 1 & 1 & \\
\hline Lichens & & & & & & & \\
\hline Alectoria nigricans (Ach.) Nyl. & upprätt tagellav & & 1 & - & 1 & - & \\
\hline A. ochroleuca (Hoffm.) Massal. & fjälltagellav & & 1 & - & 1 & - & \\
\hline Cetraria ericetorum $\mathrm{Opiz}$ & smal islandslav & 1 & 1 & 1 & 1 & & \\
\hline C. islandica (L.) Ach. & islandslav & 1 & 1 & 1 & 1 & & \\
\hline C. nivalis (L.) Ach. & snölav & - & - & - & 1 & & \\
\hline Cladina arbuscula (Wallr.) Hale \& Culb. & gulvit renlav & 1 & 1 & 1 & 1 & & \\
\hline C. rangiferina $(\mathrm{L}.) \mathrm{Nyl}$ & grå renlav & 1 & 1 & 1 & 1 & & \\
\hline C. stellaris (Opiz) Brodo & fönsterlav & - & - & - & 1 & & \\
\hline C. bellidiflora (Ach.) Schaerer & blombägarlav & 1 & 1 & 1 & 1 & & \\
\hline C. coccifera (L.) Willd. & kochenillav & - & 1 & - & 1 & & \\
\hline C. cornuta (L.) Hoffm. & syllav & 1 & 1 & 1 & 1 & & \\
\hline C. fimbriata (L.) Fr. & naggig bägarlav & - & 1 & - & 1 & & \\
\hline C. uncialis (L.) Wigg. & pigglav & 1 & 1 & 1 & 1 & & \\
\hline Cladonia spp. & bägarlavar & 1 & 1 & 1 & 1 & & \\
\hline
\end{tabular}


Meadow with low herbs, cont.

Swedish

common

Species/taxa and author

Diploschistes scruposus (Schrever) Norman

Icmadophila ericetorum (L.) Zahlbr.

Nephroma arcticum (L.) Torss.

Ochrolechia frigida (Swartz) Lynge

Peltigera aphthosa (L.) Willd.

Solorina crocea (L.) Ach.

Stereocaulon paschale (L.) Hoffm.

Other lichens

\section{Mosses}

Dicranum scoparium Hedw.

Hepaticae

Hylocomium splendens (Hedw.) Schimp.

Pleurozium schreberi (Brid.) Mitt.

Polytrichum piliferum Hedw.

Sphagnum spp.

Other mosses name

groplav

vitmosslav

norrlandslav

nordlig örnlav

torsklav

saffranslav

påskrislav

Övriga lavar

Ritsem

$\begin{array}{llll}\text { C95 } & \text { C99 } & \text { O95 } & \text { O99 }\end{array}$

kvastmossa

Levermossor

husmossa

väggmossa

hårbjörnmossa

vitmossor

Övriga mossor

\section{O99}

$\begin{array}{llll}1 & 1 & 1 & 1 \\ 1 & 1 & 1 & 1 \\ 1 & 1 & 1 & 1 \\ - & 1 & - & 1 \\ - & 1 & - & 1 \\ 1 & 1 & 1 & 1 \\ 1 & 1 & 1 & 1 \\ - & 1 & - & 1\end{array}$

$\begin{array}{ccccc} & & & & \\ & 1 & 1 & 1 & 1 \\ & 1 & - & 1 & - \\ & - & 1 & - & 1 \\ & 1 & 1 & 1 & 1 \\ & 1 & 1 & 1 & 1 \\ & - & 1 & - & 1 \\ & - & 1 & - & 1\end{array}$




\section{Appendix II. Saami names for utility goods, botanical names, villages and study sites, and list of persons who provided information}

\section{Utility goods}

\section{English}

Shovel staff or ski stick

Lapland sleigh

Cradle

Smudge fire

Saami

Goaivosoabbi

Gieres

Gietka

Suovva

\section{Species and groups}

\section{Latin or English}

Alectoria sp.

Angelica archangelica

Astragalus al pinus

Betula nana

Betula pubescens ssp. czerepanovii

Bryophyte

Bryoria fuscescens

Calluna vulgaris

Cetraria nivalis

Cladina arbuscula

C. rangiferina

C. stellaris

Cladonia coccifera

Empetrum hermaphroditum

Epidendric lichen

Epilobium angustifolium

Equisetum sp.

Fungus

Lactarius terminosus

Lichen

Menyanthes trifoliata

Nephroma sp.

Parmelia olivacea

Rhododendron lapponicum

Rumex acetosa ssp. lapponicus

Salix phylicifolia

Solidago virgaurea

Stereocaulon paschale

Usnea filipendula

Saami
Láigejeagil
boska
duottarsaphal
skierre
lageš
seamul
guossalahppu
livdnju
fiskesjeagil
roancejeagil
ránesjeagil
oaivejeagil
bohccejeagil
cähppesmuorji
lahppu
horbmá
gorddet
guoppar
riesaraski
jeagil
Muošká
Jorgqujeagil
beassegatna
duottarčikna
joupmu
ruksessieðga
beatnatjuovččarassi
smarvejeagil
láigejeagil

Saami villages

\section{English}

Talma

Lainiovuoma

Saarivuoma

Mellanbyn

Sörkaitum

Mittådalen

Idre nya sameby

Fulufjället

\section{Study sites}

English

Tjuolmajaure

Poullanvare

Tavvavuoma

Ritsem

Sånfjället

Långfjället

Fulufjället
Saami

Talma

Lainiovuoma

Saarivuoma

Báste Cearru

Unnat jårro

Mihte

Idre nya sameby

Fulufjället

Saami

Cuolmmajavri

Boullánvarri

Davvavuopmi

Rijtjem 


\section{Persons who provided information}

Baer, Lars. herder, chairman. Saarivuoma

Berggren, Lars. assistant bailiff. Vittangi

Blind, Olof. herder, chairman. Talma

Idivuoma, Per. herder, chairman. Lainiovuoma

Mellkvist, Hannes. senior of ficer, county administration. Dalarna

Mikaelsson, Stefan. herder. Rödingträsk

Rönnbäck, Jan-Ivar. senior of ficer, county administration. Norrbotten

Ruong, Israel. professor. Uppsala

Skum, Nickolaus, herder, chairman Norrkaitum 


\section{SVENSKA VÄXTGEOGRAFISKA SÄLLSKAPET \\ SOCIETAS PHYTOGEOGRAPHICA SUECANA \\ Adress: Avdelningen för växtekologi, Uppsala Universitet, Villavägen 14, SE-752 36 Uppsala, Sweden}

Sällskapet har till ändamål att väcka och underhålla intresse för växtgeografien i vidsträcktaste mening, att främja utforskande av flora och vegetation i Sverige och andra länder och att hävda geobotanikens praktiska och vetenskapliga betydelse.

Sällskapet anordnar sammankomster och exkursioner samt utger en publikationsserie. Medlemskap kan erhållas efter anmälan hos sekreteraren. Föreningar, bibliotek, läroanstalter och andra institutioner kan ingå som abonnenter.

Sällskapet utger årligen Acta Phytogeographica Suecica. Medlemmar och abonnenter erhåller årets Acta mot postförskott på årsavgiften jämte porto och expeditionskostnader.

Vissa år utges extra band av Acta, som erhålls mot en tilläggsavgift.

Sällskapet har tidigare utgivit den ickeperiodiska serien Studies in Plant Ecology (vols. 1-20 Växtekologiska studier). Den kan förvärvas efter beställning hos OPULUS PRESS AB, Gamla vägen 40, SE-770 13 Grangärde, Sweden.
The object of the Society is to promote investigations in flora and vegetation, their history and their ecological background. Through publication of monographs, and other activities, the Society tries to stimulate geobotanical research and its application to practical and scientific problems.

Individual members and subscribers (societies, institutes, libraries, etc.) receive Acta Phytogeographica Suecica on payment of the annual membership fee. There are additional fees in years when more than one volume is issued. For membership please, apply to the Secretary.

The Society has also issued Studies in Plant Ecology (vols. 1-20 Växtekologiska studier). All volumes are still available and can be ordered through OPULUS PRESS AB, Gamla vägen 40, SE-770 13 Grangärde, Sweden.

\section{ACTA PHYTOGEOGRAPHICA SUECICA}

1. E. Almquist. 1929. Upplands vegetation och flora. (Vegetation and flora of Uppland.) Out of print.

2. S. Thunmark. 1931. Der See Fiolen und seine Vegetation. ISBN 91-7210-002-8. Price: SEK 240.

3. G. E. Du Rietz. 1931. Life-forms of terrestrial flowering plants. I. ISBN 91-7210-003-6. Price: SEK 160.

4. B. Lindquist. 1932. Om den vildväxande skogsalmens raser och deras utbredning i Nordvästeuropa. (Summ.: The races of spontaneous Ulmus glabra Huds. and their distribution in NW Europe.) Out of print.

5. H. Osvald. 1933. Vegetation of the Pacific coast bogs of North America. ISBN 91-7210-005-2. Price: SEK 160.

6. G.Samuelsson. 1934. Die Verbreitung der höheren Wasserpflanzen in Nordeuropa. 1934. Out of print.

7. G. Degelius. 1935. Das ozeanische Element der Strauchund Laubflechtenflora von Skandinavien. Out of print.

8. R. Sernander. 1936. Granskär och Fiby urskog. En studie över stormluckornas och marbuskarnas betydelse i den svenska granskogens regeneration. (Summ.: The primitive forests of Granskär and Fiby. A study of the part played by storm-gaps and dwarf trees in the regeneration of the Swedish spruce forest.) ISBN 91-7210-008-7. Price: SEK 240.

9. R. Sterner. 1938. Flora der Insel Öland. Die Areale der Gefässpflanzen Ölands nebst Bemerkungen zu ihrer Oekologie und Soziologie. Out of print.

10. B. Lindquist. 1938. Dalby Söderskog. En skånsk lövskog i forntid och nutid. (Zusammenf.: Ein Laubwald in Schonen in der Vergangenheit und Gegenwart.) ISBN 91-7210-010-9. Price: SEK 240.

11. N. Stålberg. 1939. Lake Vättern. Outlines of its natural history, especially its vegetation. ISBN 91-7210-011-7. Price: SEK 160.

12. G.E.Du Rietz, A. G. Hannerz, G. Lohammar, R. Santesson \& M. Warn. 1939. Zur Kenntnis der Vegetation des Sees
Tåkern. ISBN 91-7210-012-5. Price: SEK 160.

13. Växtgeografiska studier tillägnade Carl Skottsberg på sextioårsdagen 1/12 1940. (Geobotanical studies dedicated to C. Skottsberg.) 1940. ISBN 91-7210-013-3. Price: SEK 290.

14. N. Hylander. 1941. De svenska formerna av Mentha gentilis L. coll. (Zusammenf.: Die schwedischen Formen der Mentha gentilis L. sensu coll.) ISBN 91-7210-014-1. Price: SEK 160.

15. T. E. Hasselrot. 1941. Till kännedom om några nordiska umbilicariacéers utbredning. (Zusammenf.: Zur Kenntnis der Verbreitung einiger Umbilicariaceen in Fennoscandia.) ISBN 91-7210-015-X. Price: SEK 240.

16. G.Samuelsson. 1943. Die Verbreitung derAlchemilla-Arten aus der Vulgaris-Gruppe in Nordeuropa. ISBN 91-7210016-8. Price: SEK 160.

17. Th. Arwidsson. 1943. Studien überdie Gefässpflanzen in den Hochgebirgen der Pite Lappmark. ISBN 91-7210-017-6. Price: SEK 240.

18. N.Dahlbeck. 1945. Strandwiesen am südöstlichenÖresund. (Summ.: Salt marshes on the S. E. coast of Öresund.) ISBN 91-7210-018-4. Price: SEK 160.

19. E. von Krusenstjerna. 1945. Bladmossvegetation och bladmossflora i Uppsalatrakten. (Summ.: Moss flora and moss vegetation in the neighbourhood of Uppsala.) ISBN 91-7210-019-2. Price: SEK 290.

20. N. Albertson. 1946. Österplana hed. Ett alvarområde på Kinnekulle. (Zusammenf.: Österplana hed. Ein Alvargebiet auf dem Kinnekulle.) ISBN 91-7210-020-6. Price: SEK 240.

21. H.Sjörs. 1948. Myrvegetation i Bergslagen. (Summ.: Mire vegetation in Bergslagen, Sweden.) ISBN 91-7210-021-4. Price: SEK 290.

22. S. Ahlner. 1948. Utbredningstyper bland nordiska barrträdslavar. (Zusammenf.: Verbreitungstypen unter fennoskan- 
dischen Nadelbaumflechten.) ISBN 91-7210-022-2.Price: SEK 240.

23. E. Julin. 1948. Vessers udde, mark och vegetation i en igenväxande löväng vid Bjärka-Säby. (Zusammenf.: Vessers udde. Boden und Vegetation in einer verwachsenden Laubwiese bei Bjärka-Säby in Östergötland, Südschweden.) ISBN 91-7210-023-0. Price: SEK 240.

24. M.Fries. 1949. Den nordiska utbredningen av Lactuca alpina, Aconitum septentrionale, Ranunculus platanifolius och Polygonatum verticillatum. (Zusammenf.: Die nordische Verbreitung von Lactuca alpina, Aconitum septentrionale, Ranunculus platanifolius und Polygonatum verticillatum.) ISBN 91-7210-24-9. Price: SEK 160.

25. O. Gjorevoll. 1949. Snøleievegetasjonen i Oviksfjellene. (Summ.: The snow-bed vegetation of Mts Oviksfjällen, Jämtland, Sweden.) ISBN 91-7210-025-7. Price: SEK 160.

26. H. Osvald. 1949. Notes on the vegetation of British and Irish mosses. ISBN 91-7210-026-5. Price: SEK 160.

27. S. Selander. 1950. Floristic phytogeography of southwestern Lule Lappmark (Swedish Lapland). I. 1950. ISBN 91-7210027-3. Price: SEK 240.

28. S.Selander. 1950. Floristic phytogeography of southwestern Lule Lappmark (Swedish Lapland). II. Kärlväxtfloran i sydvästra Lule Lappmark. (Summ.: Vascular flora.) ISBN 91-7210-028- 1. Price: SEK 160.

29. M.Fries. 1951. Pollenanalytiska vittnesbörd om senkvartär vegetationsutveckling, särskilt skogshistoria, i nordvästra Götaland. (Zusammenf.: Pollenanalytische Zeugnisse der spätquartären Vegetationsentwicklung, hauptsächlich der Waldgeschichte, im nordwestlichen Götaland, Südschweden.) ISBN 91-7210-029-X. Price: SEK 240.

30. M.Warn. 1952. Rocky-shore algae in the ÖregrundArchipelago. ISBN 91-7210-030-3. Price: SEK 290.

31. O.Rune. 1953. Plant life on serpentines and related rocks in the North of Sweden. 1953. ISBN 91-7210-031-1. Price: SEK 240.

32. P. Kaaret. 1953. Wasservegetation der Seen Orlången und Trehörningen. ISBN 91-7210-032-X. Price: SEK 160.

33. T. E. Hasselrot. 1953. Nordliga lavar i Syd- och Mellansverige. (Nördliche Flechten in Süd- und Mittelschweden.) ISBN 91-7210-033-8. Price: SEK 240.

34. H.Sjörs. 1954. Slåtterängar i Grangärde Finnmark. (Summ.: Meadows in Grangärde Finnmark, SW Dalarna, Sweden.) ISBN 91-7210-034-6. Price: SEK 160.

35. S. Kilander. 1955. Kärlväxternas övre gränser på fjäll i sydvästra Jämtland samt angränsande delar av Härjedalen och Norge. (Summ.: Upper limits of vascular plants on mountains in southwestern Jämtland and adjacent parts of Härjedalen (Sweden) and Norway.) ISBN 91-7210-035-4. Price: SEK 240.

36. N. Quennerstedt. 1955. Diatoméerna i Långans sjövegetation. (Summ.: Diatoms in the lake vegetation of the Långan drainage area, Jämtland, Sweden.) ISBN 91-7210036-2. Price: SEK 240.

37. M.-B. Florin. 1957. Plankton of fresh and brackish waters in the Södertälje area. ISBN 91-7210-037-0. Price: SEK 160.

38. M.-B. Florin. 1957. Insjöstudier i Mellansverige. Mikrovegetation och pollenregn i vikar av Östersjöbäckenet och ins jöar från preboreal tid till nutid. (Summ.: Lake studies in central Sweden. Microvegetation and pollen rain in inlets of the Baltic basin and in lakes from Preboreal time to the present day.) ISBN 91-7210-038-9. Price: SEK 160.

39. M. Fries. 1958. Vegetationsutveckling och odlingshistoria i Varnhemstrakten. En pollenanalytisk undersökning i Västergötland. (Zusammenf.: Vegetationsentwicklung und Siedlungsgeschichte im Gebiet von Varnhem. Eine pollenanalytische Untersuchung aus Västergötland (Südschweden).) ISBN 91-7210-039-7. Price: SEK 160.

40. B. Pettersson. 1958. Dynamik och konstans i Gotlands flora och vegetation. (Zusammenf.: Dynamik und Konstanz in der Flora und Vegetation von Gotland, Schweden.) ISBN 91-7210-040-0. Price: SEK 400.

41. E. Uggla. 1958. Skogsbrandfält i Muddus nationalpark. (Summ.: Forest fire areas in Muddus NationalPark, northern Sweden.) ISBN 91-7210-041-9. Price: SEK 160.

42. K. Thomasson. 1959. Nahuel Huapi. Plankton of some lakes in an Argentina National Park, with notes on terrestrial vegetation. ISBN 91-7210-042-7. Price: SEK 160.

43. V. Gillner. 1960. Vegetations- und Standortsuntersuchungen in den Strandwiesen der schwedischen Westküste. ISBN 91-7210-043-5. Price: SEK 240.

44. E. Sjögren. 1961. Epiphytische Moosvegetation in Laubwäldern der Insel Öland, Schweden. (Summ.: Epiphytic moss communities in deciduous woods on the island of Öland, Sweden.) ISBN 917210-044-3 (ISBN 91-7210444-9). Price: SEK 160.

45. G. Wistrand. 1962. Studier i Pite Lappmarks kärlväxtflora, med särskild hänsyn till skogslandet och de isolerade fjällen. (Zusammenf.: Studien über die Gefässpflanzenflora der Pite Lappmark mit besonderer Berücksichtigung des Waldlandes und der isolierten niederen Fjelde.) ISBN 91-7210-045-1 (ISBN 91-7210-445-7). Price: SEK 240.

46. R. Ivarsson. 1962. Lövvegetation i Mollösunds socken. (Zusammenf.: Die Laubvegetation im Kirchspiel Mollösund, Bohuslän, Schweden.) ISBN 91-7210-046-X (ISBN 91-7210-446-5). Price: SEK 160.

47. K. Thomasson. 1963. Araucanian Lakes. Plankton studies in North Patagonia, with notes on terrestrial vegetation. ISBN 91-7210-047-8. Price: SEK 240.

48. E. Sjögren. 1964. Epilitische und epigäische Moosvegetation in Laubwäldern der Insel Öland, Schweden. (Summ.: Epilithic and epigeic moss vegetation in deciduous woods on the island of Öland, Sweden.) ISBN 91-7210-048-6 (ISBN 91-7210-448-1). Price: SEK 240.

49. O. Hedberg. 1964. Features of afroalpine plant ecology. (Résumé français.) ISBN 91-7210-049-4 (ISBN 91-7210449-X). Price: SEK 240.

50. The plant cover of Sweden. A study dedicated to G. Einar Du Rietz on his 70th birthday by his pupils. 1965. ISBN 91-7210-050-8. Price: SEK 460.

51. T. Flensburg. 1967. Desmids and other benthic algae of Lake Kävsjön and Store Mosse. SW Sweden. ISBN 917210-051-6 (ISBN 91-7210-451-1). Price: SEK 240.

52. E. Skye. 1968. Lichens and air pollution. A study of cryptogamic epiphytes and environment in the Stockholm region. ISBN 91-7210-052-4 (ISBN 91-7210-452-X). Price: SEK 240.

53. J. Lundqvist. 1968. Plant cover and environment of steep hillsides in Pite Lappmark. (Résumé: La couverture végétale et l'habitat des flancs escarpés des collines de Pite Lappmark.) ISBN 91-7210-053-2 (ISBN 91-7210-453-8). Price: SEK 240. 
54. Conservation of vegetation in Africa south of the Sahara. Proceedings of a symposium held at the 6th Plenary meeting of the AETFAT, Uppsala Sept. 12-16, 1966. I. \& O. Hedberg (eds.) 1968. ISBN 91-7210-054-0 (ISBN 91-7210-454-6). Price: SEK 290.

55. L.-K. Königsson. 1968. The Holocene history of the Great Alvar of Öland. ISBN 91-7210-055-9 (ISBN 91-7210455-4). Price: SEK 290.

56. H. P. Hallberg. 1971. Vegetation auf den Schalenablagerungen in Bohuslän, Schweden. (Summ.: Vegetation on shell deposits in Bohuslän, Sweden.) ISBN 91-7210-056-7 (ISBN 91-7210-456-2). Price: SEK 240.

57. S. Fransson. 1972. Myrvegetation i sydvästra Värmland. (Summ.: Mire vegetation in southwestern Värmland, Sweden.) ISBN 91-7210-057-5 (ISBN 91-7210-457-0). Price: SEK 240.

58. G. Wallin. 1973. Lövskogsvegetation i Sjuhäradsbygden. (Summ.: Deciduous woodlands in Sjuhäradsbygden, Västergötland, southwestern Sweden.) ISBN 91-7210058-3 (ISBN 91-7210-458-9). Price: SEK 240.

59. D. Johansson. 1974. Ecology of vascular epiphytes in West African rain forest. (Résumé: Ecologie des épiphytes vasculaires dans la forêt dense humide d'Afrique occidentale.) ISBN 91-7210059-1 (ISBN 91-7210-459-7). Price: SEK 290.

60. H.Olsson. 1974. Studies on South Swedish sand vegetation. ISBN 91-7210-060-5 (ISBN 91-7210-460-0). Price: SEK 240.

61. H. Hytteborn. 1975. Deciduous woodland at Andersby, eastern Sweden. Above-ground tree and shrub production. ISBN 91-7210-061-3 (ISBN 91-7210-461-9). Price: SEK 240.

62. H.Persson. 1975. Deciduous woodland atAndersby, eastern Sweden. Field-layer and below-ground production. ISBN 91-7210-062-1 (ISBN 91-7210-462-7). Price: SEK 160.

63. S. Bråkenhielm. 1977. Vegetation dynamics of afforested farmland in a district of south-eastern Sweden. ISBN 917210-063-X (ISBN 91-7210-463-5). Price: SEK 240.

64. M. Y. Ammar. 1978. Vegetation and local environment on shore ridges at Vickleby, Öland, Sweden. An analysis. ISBN 91-7210-064-8 (ISBN 91-7210-464-3). Price: SEK 240.

65. L. Kullman. 1979. Change and stability in the altitude of the birch tree-limit in the southern Swedish Scandes 1915 1975. ISBN91-7210-065-6(ISBN 91-7210-465-1). Price: SEK 240.

66. E. Waldemarson Jensén. 1979. Successions in relationship to lagoon development in the Laitaure delta, North Sweden. ISBN 91-7210-066-4 (ISBN 91-7210-466-X). Price: SEK 240.

67. S. Tuhkanen. 1980. Climatic parameters and indices in plant geography. ISBN 91-7210-067-2 (ISBN 91-7210-467-8). Price: SEK 240.

68. Studies in plant ecology dedicated toHugoSjörs. E. Sjögren (ed.) 1980. ISBN 91-7210-068-0 (ISBN 91-7210-468-6). Price: SEK 290.

69. C. Nilsson. 1981. Dynamics of the shore vegetation of a North Swedish hydro-electric reservoir during a 5-year period. ISBN 91-7210-069-9(ISBN 91-7210-469-4). Price: SEK 240.

70. $K$. Warenberg. 1982. Reindeer forage plants in the early grazing season. Growth and nutritional content in relation to climatic conditions. ISBN 91-7210-070-2 (ISBN 917210-470-8). Price: SEK 240.

71. C. Johansson. 1982. Attached algal vegetation in running waters of Jämtland, Sweden. ISBN 917210-071-0 (ISBN 91-7210-471-6). Price: SEK 240.

72. E. Rosén. 1982. Vegetation development and sheep grazing in limestone grasslands of South Öland, Sweden. ISBN 91-7210-072-9 (ISBN 91-7210-472-4). Price: SEK 290.

73. Zhang Liquan. 1983. Vegetation ecology and population biology of Fritillaria meleagris L. at the Kungsängen Nature Reserve, eastern Sweden. ISBN 91-7210-073-7 (ISBN 917210-473-2). Price: SEK 240.

74. I. Backéus. 1985. Aboveground production and growth dynamics of vascular bog plants in central Sweden. ISBN 91-7210-074-5 (ISBN 91-7210-474-0). Price: SEK 240.

75. E. Gunnlaugsdóttir. 1985. Composition and dynamical status of heathland communities in Iceland in relation to recovery measures. ISBN 91-7210-075-3 (ISBN 91-7210475-9). Price: SEK 240.

76. Plant cover on the limestone Alvar on Öland. Ecologysociology-taxonomy. E. Sjögren (ed.) 1988. ISBN 91-7210076-1 (ISBN 91-7210-476-7). Price: SEK 320.

77. Á. H. Bjarnason. 1991. Vegetation on lava fields in the Hekla area, Iceland. ISBN 91-7210-077-X (ISBN 917210-477-6). Price: SEK 290.

78. Algological studies of nordic coastal waters - A festschrift to Prof. Mats Wærn on his 80th birthday-. I. Wallentinus \& P. Snoeijs (eds.). 1992. ISBN 91-7210-078-8 (ISBN 91-7210-478-3 ). Price: SEK 290.

79. Tamrat Bekele. 1994. Vegetation ecology of remnantAfromontane forests on the Central Plateau of Shewa, Ethiopia. ISBN 91-7210-079-6 (ISBN 91-7210-479-1). Price: SEK 290.

80. M. Diekmann. 1994. Deciduous forest vegetation in Boreo-nemoral Scandinavia. ISBN 91-7210-080-X (ISBN 91-7210-480-5). Price: SEK 290.

81. Plant root systems and natural vegetation. H. Persson \& I.O. Baitulin (eds.) 1996. ISBN 91-7210-081-8 (ISBN 917210-081-3). Price: SEK 290.

82. R. Virtanen \& S. Eurola 1997. Middle oroarctic vegetation in Finland and middle-northern arctic vegetation on Svalbard. ISBN 91-7210-082-6. (91-7210-482-5). Price: SEK 290.

83. E. Kaźmierczak. 1997. The vegetation of kettle-holes in central Poland. ISBN 91-7210-083-4. (91-7210-483-X). Price: SEK 290.

84. Swedish plant geography - dedicated toEddy van derMaarel on his 65th birthday-. H. Rydin, P. Snoeijs \& M. Diekmann (eds.) 1999. ISBN 91-7210-084-2 (ISBN 91-7210-484-8). Price: SEK 400.

85. Succession and zonation on mountains, particularly on volcanoes - Dedicated to Erik Sjögren on his 65th birthday-. E. van der Maarel (ed.) 2002. ISBN 91-7210-085-0 (ISBN 91-7210-485-6). Price: SEK 290.

86. S. Fransson. 2003. Bryophyte vegetation on cliffs and screes in Western Värmland, Sweden. ISBN 91-7210-086-9 (ISBN 91-7210-486-4). Price: SEK 290.

87. O. Eriksson, M. Niva \& A. Caruso. 2007. Use and abuse of reindeer range. ISBN 978-91-7210-087-9 (ISBN 97891-7210-487-7). Price: SEK400. 


\section{STUDIES IN PLANT ECOLOGY (VOL. 1-20)}

1. S. Bråkenhielm \& T. Ingelög. 1972. Vegetationen i Kungshamn-Morga naturreservat med förslag till skötselplan. (Summ.: Vegetation and proposed management in the Kungshamn-Morga Nature Reserve south of Uppsala.) ISBN 91-7210-801-0. Price: SEK 112.

2. T. Ingelög \& M. Risling. 1973. Kronparken vid Uppsala, historik och beståndsanalys av en 300-årig tallskog. (Summ.: Kronparken, history and analysis of a 300-year old pinewood near Uppsala, Sweden.) ISBN 91-7210-802-9. Price: SEK 112.

3. H. Sjörs et al. 1973. Skyddsvärda myrar i Kopparbergs län. [Summ.: Mires considered for protection in Kopparberg County (Prov. Dalarna, central Sweden.)] ISBN 91-7210803-7. Price: SEK 112.

4. L. Karlsson. 1973. Autecology of cliff and scree plants in Sarek National Park, northern Sweden 1973. ISBN 917210-804-5. Price: SEK 160.

5. B. Klasvik. 1974. Computerized analysis of stream algae. ISBN 91-7210-805-3. Price: SEK 112.

6. Y. Dahlström-Ekbohm. 1975. Svensk miljövårds- och omgivningshygienlitteratur 1952-1972. Bibliografi och analys. ISBN 91-7210-806-1. Price: SEK 112.

7. L. Rodenborg. 1976. Bodennutzung, Pflanzenwelt und ihre Veränderungen in einem alten Weidegebiet auf MittelÖland, Schweden. ISBN 91-7210-807-X. Price: SEK 112.

8. H.Sjörs \& Ch. Nilsson. 1976. Vattenutbyggnadens effekter på levande natur. En faktaredovisning övervägande från Umeälven. (Summ.: Bioeffects of hydroelectric development. A case study based mainly on observations along the Ume River, northern Sweden.) ISBN 91-7210-808-8. Price: SEK 160.

9. J. Lundqvist \& G. Wistrand. 1976. Strandflora inom övre och mellersta Skellefteälvens vattensystem. Med en sammanfattning beträffande botaniska skyddsvärden. (Summ.: Riverside vascular florain the upper and middle catchment area of the River Skellefteälven, northern Sweden.) ISBN 91-7210-809-6. Price: SEK 112.
10. A. Müller-Haeckel. 1976. Migrationsperiodik einzelliger Algen in Fliessgewässern. ISBN 91-7210-810-X. Price: SEK 112.

11. Å.Sjödin. 1980. Index to distribution maps of bryophytes 1887-1975. I. Musci. (hard-bound). ISBN 91-7210-811-8. Price: SEK 160.

12. A. Sjödin. 1980. Index to distribution maps of bryophytes 1887-1975. II. Hepaticae. (hard-bound). ISBN 91-7210812-6. Price: SEK 112.

13. O. Eriksson, T. Palo \& L. Söderström. 1981. Renbetning vintertid. Undersökningar rörande svensk tamrens näringsekologi under snöperioden. ISBN 91-7210-813-4. Price: SEK 112.

14. G. Wistrand. 1981. Bidrag till Pite lappmarks växtgeografi. ISBN 91-7210-814-2. Price: SEK 112.

15. T. Karlsson. 1982.Euphrasiarostkovianai Sverige. (English summ.). ISBN 91-7210-815-0. Price: SEK 160.

16. Theory and models in vegetation science: Abstracts. R. Leemans, I.C. Prentice \& E. van der Maarel (eds.) 1985. ISBN 91-7210-816-9. Price: SEK 160.

17. I. Backéus. 1988. Mires in the Thaba-Putsoa Range of the Maloti, Lesotho. ISBN 91-7210-817-7. Price: SEK 160.

18. Forests of the world - diversity and dynamics (Abstracts) E. Sjögren (ed.) 1989. ISBN 91-7210-818-5. Price: SEK 290.

19. E. Sjögren. 1994. Changes in the epilithic and epiphytic moss cover in two deciduous forest areas on the island of Öland (Sweden). - A comparison between 1958-1962 and 1988-1990. ISBN 91-7210-819-3. Price: SEK 200.

20. Vegetation science in retrospect and perspective (Abstracts) 1998. E. Sjögren, E. van der Maarel \& G. Pokarzhevskaya (eds.) ISBN 91-7210-820-7. Price: 160 SEK.

Distributor: 

Distributor: OPULUS PRESS AB, Sweden

ISBN 978-91-7210-087-9 (ISBN 978-91-7210-487-7)

ISSN 0084-5914 